\title{
De ontwikkeling van het praktisch medisch onderwijs in de huisartspraktijk
}

Citation for published version (APA):

Bouhuijs, P. A. J. (1983). De ontwikkeling van het praktisch medisch onderwijs in de huisartspraktijk. [Doctoral Thesis, Maastricht University]. Rijksuniversiteit Limburg.

https://doi.org/10.26481/dis.19830603pb

Document status and date:

Published: 01/01/1983

DOI:

10.26481/dis.19830603pb

Document Version:

Publisher's PDF, also known as Version of record

\section{Please check the document version of this publication:}

- A submitted manuscript is the version of the article upon submission and before peer-review. There can be important differences between the submitted version and the official published version of record.

People interested in the research are advised to contact the author for the final version of the publication, or visit the DOI to the publisher's website.

- The final author version and the galley proof are versions of the publication after peer review.

- The final published version features the final layout of the paper including the volume, issue and page numbers.

Link to publication

\footnotetext{
General rights rights.

- You may freely distribute the URL identifying the publication in the public portal. please follow below link for the End User Agreement:

www.umlib.nl/taverne-license

Take down policy

If you believe that this document breaches copyright please contact us at:

repository@maastrichtuniversity.nl

providing details and we will investigate your claim.
}

Copyright and moral rights for the publications made accessible in the public portal are retained by the authors and/or other copyright owners and it is a condition of accessing publications that users recognise and abide by the legal requirements associated with these

- Users may download and print one copy of any publication from the public portal for the purpose of private study or research.

- You may not further distribute the material or use it for any profit-making activity or commercial gain

If the publication is distributed under the terms of Article $25 \mathrm{fa}$ of the Dutch Copyright Act, indicated by the "Taverne" license above, 
De ontwikkeling van het Praktisch Medisch Onderwijs in de Huisartspraktijk

\section{Proefschrift}

ter verkrijging van de graad van doctor in de geneeskunde aan de Rijksuniversiteit Limburg te Maastricht op gezag van de Rector Magnificus Prof. dr. H.C. Hemker, volgens besluit van hel College van Dekanen in het openbaar te verdedigen op vrijdag 3 juni 1983 om vier uur precies, in de aula van de universiteit door

Petrus Adrianus Johannes Bouhuijs

geboren te Teteringen 
Promotor: Prot.dr. W.H.F.W. Wiljnen

Co-promotor: Prof.dr. W. Brouwer

Referenten: Prof ar. D.W. Vaags

Prof.dr. P.J.M. van der Lugt

Druk: $\quad$ Meerstad, Mastrlcht 1983. 


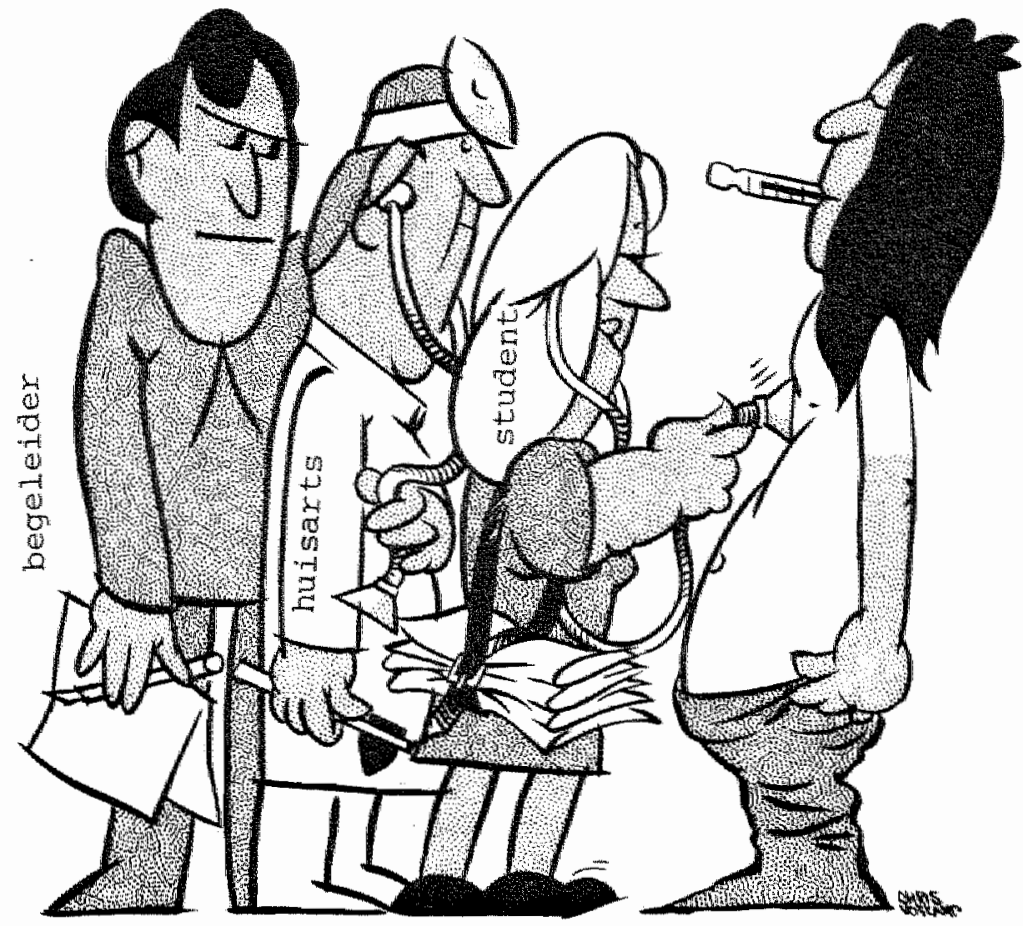

De essentle van het Praktisch Medisch Onderwijs in de Hulsartspraktljk volgens Chris voskamp. 


\section{Inhoud}

paglna

VOOFWOORO

INLLE IDING

HOOFOSTUK 1: Onderw ilkunde en stages 2

1.1. Inlelding 2

1.2. Onderwljskunde van het Hoger Onderwijs 2

1.3. Stages 7

1.3.1. Een onschirljuling wan het begrlp 'stage' 8

1.4. Stages in het medisch onderwijs 12

HOOFDSTUK 2: De ontwlkkelling van het PraktIsch Medlsch OnderwiJs in de HulsartspraktlJk 17

2.1. Inlelding 17

2.2. Het PMOH in het Meastrlchtse currlculum 17

2.3. De ontwikkeling $v$ an het stagemodel 22

2.3.1. Chronologisch overzlcht wan het pllaniningproces 22

2.3.2. Concretiserling van de stage-opzet 24

2.4. De onderwils seersituatle 27

2.4.1. Activitelten in de hulsartspraktljk 27

2.4.2. Verslaglegglng 30

2.4.3. Onderwi Jsgroepen 34

2.4 .4 * Blokboelk 35

2.4.5. De nol van de hulsarts-oplelder 37

2.4.6. De hulsarts-begeldider 38

2.5. Werving en voorberelding van hulsartsoplelders 
HOOFDSTUK 3: Booordeling en evaluatle 44

3.1 .

Inleiding

$3 \cdot 2$.

Beoordelling van de vorderingen van

studenten

3.2 .1 .

De beoordelingstillosofie van de facultelt

3.2 .2 . Stagebecoordel Ingen

3.3.

Eval uatle van de stage

3.3 .1$.

De functle van programa-evaluatle

3.3 .2 . informat lebronnen ten behoeve van programa-eval uatle

$3 \cdot 3 \cdot 3$ Opmerkingen over de rapportage van de programa-eval uatle

HOOFOSTUK 4: Het wer loop van de stage in het studleJar $1978 / 79$

4.1.

inlelding

4.2 .

Activitelten van de student in de hulsartspraktijk

$4 \cdot 2 \cdot 1$.

Het ondervragen en onderzoeken van

patlënten

$4 \cdot 2 \cdot 2$

Overlge activiteiten in de praktijk

4.3. De onderwljsgrcepen en het contact met de hulsarts-begelelder

4.4 .

Gagevens over de tijdsbested Ing van

studenten

4.4.1.

Beschrifving van de reglstratle van t Jdsbesteding

$4 \cdot 4 \cdot 2$. Resultaten

HOOFOSTUK 5: Medische vaardigheden en competentle 75

5.1. Inleiding

5.2 .

Zelt-oordelen van studenten en globoal oordeel van oplelders

$5 \cdot 2 \cdot 1$.

De vaardigheldscheck IIst

$5 \cdot 2 \cdot 2$.

Resultaten

$5 \cdot 2 \cdot 3$.

Terugkoppelling van resul tatem naar studenten en hulsarts-opleiders

5.3. Beoordeling van het student-patleantcontact 


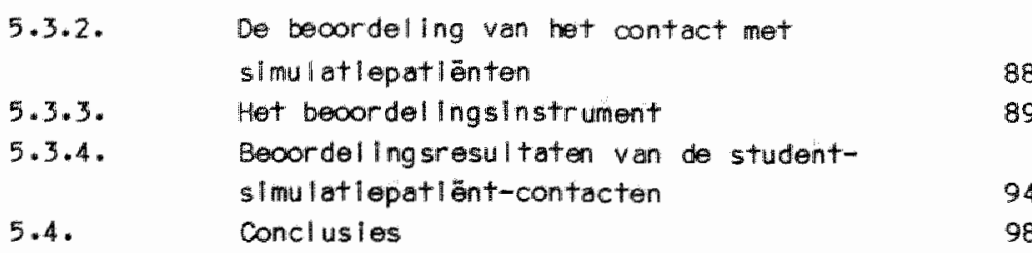

HOOFDSTUK 6: Attitude an titudeverandering in het PMOH

6.1 .

In lleiding

6.2 .

De Masatrichtse hulsartsenvragen llljst

6.3. Yir aagstel I Ing

Resultaten met betrekking tot de

Maastr lchtse hulsartsenvragenl ll st

106

6.5.

Het oordeal wan oplelders over het

functioneren van studenten in relatie

tot patlënten

HOOFDSTUK 7: Beoordeling van de verslaglegging

$7 \cdot 2$.

Wijze ven becordelen

HOOFDSTUK 9: Het PMOH in perspectlef: verander Ingen, conclusies a anbevellingen 130

9.1. Inlelaling 
9.9.

Het praktisch medisch onderwlys in de hull sartspraktljk in de toekomst

9.9 .1 .

De beschikbaarheld wan st agep lleatsen

$9 \cdot 9 \cdot 2$ * Praktisch medisch anderwlls in de hulsartspraktljk of stage hulsartsgeneeskunde?

SUMMARY

BI JLAGEN

L. I TERATUUR 
$-\mathrm{V}-$ 


\section{Voorwoord}

Dit proefschrlft heeft als onderwerp de ontwikkeling van een stageprograma in hulsartspraktiJken en bevat en hoeveelheld gegevens over het functloneren van dit programma. Een dergellike rapportege kan alleen tot stand komen, wanneer vele mensen hun medewerking ver lenen. In de eerste plaats collega-docenten van de facultelt der geneeskunde, die verantwoordel ljk waren voor de opzet en ultwoering wan het stageprograma. Hun stimulerende Invloed heeft ertoe geleld, dat lk nlet alleen aan het proefschrlft begon, maar het ook afimaakte.

Speciale vermelding verdlent Tonja Mol, dle als centrale persoon in de organ Isatle rond dit stageprogramna op velerlel wile behulpzaam is gewest bij de totstandkonling van dit proefschrlft.

Verwolgens ben $1 k$ dank verschuldigd aan de studenten en hulsartsen, dle in het studlejar $1978 / 79$ deze stage voor de eerste maal realiseerden en die bereld waren mee te werken aan dit onder zoek.

De secretarlaten van de capacitelltsgroepen Hulsartsgeneeskunde en Onderwljsontwlkkel ing on OnderwlJ sresearch verzorgden in de loop der jaren de administratleve ondersteuning voor dit onderzoek. Anton de Porto, Piet Zinken, Math ReintJens, Bert Kerkhots on WIm GiJselaers verleenden medewerking aan de verzanelling en bewerking van het onderzoeksmater laal.

Miljn promotoren, Wynand Wijnen en Wim Brouwer, dank lk vooral voor het begrlp, dat zll toonden voor mijn sterk wisselende werktempo. Hun zachte verwlJ ten bleken de Juliste stimulans om het aangewangen werk af te ronden. Wlm Waags en Paull van der Lugt leverden als referenten wardevolle krltlek op het concept-proefschrift.

Plet Pleters verzorgde de engel se samenvatting ven dit proefschrift. Ell IJ Meertens tenslotte typte nauwgezet de elndtekst en de versles, die daaraan vooraf gingen.

Meerssen, apr II 1983.

Peter A.J. Bouhulys. 


\section{Inleiding}

Het onderwerp van dit proefschrlft is de opzet an ovaluatio wan ean stage wan drllo maanden in do hulsartspraktljk, zoals dis is gereallseerd an de facultelt der geneeskunde in Mastrlcht. De nadruk ligt In dit onderzook op de totstandkoming van dit stogeprograma en de will ze warop dit programo in het erste Jaar van reallsatio is ultgovoerd. Daarnaast wordt andacht besteed aen de verdere ontwikkeling van het stageprograma In de navolgende jaren. De hoofdstukken van dlt piroefschillt kunnen in vler delen worden gegroepeerd:

In hoofdstuk 1 wordt het onderzoek geplatst tegen de achtergrond van het onderwilj sikundig onderzook met betrokking tot het Hoger Onderwils. Dok wordt in dit hoofdstuk Ingegaan op het begrlp "stage" en de rol van stages in het medisch onderwijs.

Hoofdstuk 2 en 3 geven een overzlcht van de ontwlikkellingsactivitellten, voorafgaande aan de realisatle van het stageprograma. In hoofdstuk 3 wordt de planning van de gegevensverzamelling over het functioneren van het stageprogrami beschreven.

Hoofdstuk $4 \mathrm{t} / \mathrm{m} 8$ wormen één door lapend geheel, warin de ervar lngen met dit stageprograma in het studledar $1978 / 79$ centrad stan. Hoofdstuk 4 is gewljd an de evaluatle van het onderwils sleerproces. De hoofdstukken 5, 6, 7 en 8 behandelem een aantal deellonderwerpen, namelljk vaardigheden en competentio, attitude en attltudeverandering, kenn l stoets ling, en vers l aglegglng.

Do hoofdstukken zlJn zodanlg opgezet, dat ze leder an afgerond goheol vorinen.

In hoofdstuk 9 worden de antwlkkellingen, die zlch in de opzet ven de stage hebben voorgedaen sinds $1978 / 79$ beschreven in het lleht van het ultgevoerde onderzoek. Dit hoofdstuk wordt afgesloten met een aantal paragrafen, dle aan de toekomst van deze stage gewljd zllin. leder hoofdstuk is voorzlen ven en Inleldende paragraat, war In beknopt wordt aangegeven, wat in het betreffende hoofdstuk aan de orde kont.

In een ultroer lge engel se semenvatting wordt gepoogd het ultgevoerde onder zoek toegankel IJk te maken voor nlet-neder l andstall gen. 


\section{Hoofdstuk 1 \\ Onderwijskunde en stages}

1.1. Inlelding.

Het onderwerp van dit onderzoek is de opzet en evaluatle van een stage van dr lo maanden in de hulisartspraktljk, zoals dle is gereal i seerd aan de facultelt der geneeskunde in Masstricht. In dit Inleldend hoofdstuk wordt het te rapporteren onderzoek en het onderwerp warop dit onderzoek betrekking heeft in een context geplaatst. Paragraaf 1.2. schetst de onderwilskund lge achtergrond van het onder zoek. Paragraaf 1.3 . Is gewiJd aan de onderwijskundlge omschrlJuling van het begrlp "stage". In paragraaf 1.4. wordt aandacht besteed aan de plaats van stages in het modisch onderwijs.

1.2. Onderwlj skunde van het Hoger OnderwlJs.

In 1963 werd aan de TH Elndhoven het eerste centrum voor onderwils sresearch ton behoeve van het wetenschappellJk onderwljs opgerlcht, met het doel tot op felten gefundeerde suggestles voor verbeterling van dat onderwijs te komen. Dit ultgangspunt was gabaseard op de veronderstelI Ing dat in het onderwlls teveel op voorwetenschappelljke wijze wordt gedacht, dat methoden van onderwljsgevon teveel zijn afgeleld ult mythologle en folklore, en dat gedetallleerde kennls over wat zlch im het onderwijs afspeelt een earste verelste is om tot meer ratlonele opzetten te komen (Meuwese, 1973). Het Elndhovense voorbeeld werd In snel tempo gevolgd door alle Nederlandse unlversitelten en hogescholen.

AanvankellJk lag de madruk sterk op zogeneande evaluatle-onderzoek. naar de effectivitelt van bepalde toegepaste onderwljsmethoden. De rol van de onderwijskundige in dergelljk onderzoek is dle van een krl+Ische bultienstaander, die aan docenten (en soms studenten) de effec- 
Hivitelt en de efflclëntle van hun inspannlagen probeert aan te tonen. Meuwese (1973) toonde zlch al meer dan $10 \mathrm{Jaar}$ geleden pessimistisch over de mogell Ikheden van ovaluatle-onder zoek. Het lage rendement van dergellJk ander zoek wordt volgens Meumese veroorzakt doardat geen relatlas opgespoord kunnen worden tussen kenmerken van de onder wissituatle en onderwijseffecten. Dlt latste zou alleen kunnen wanneer het anderwlJsystem rathones! goconstrueerd is. Dat gebeurt in weal gevallen echter nilat of nlet voldoends. Onderwljskundlgen zouden zlch volgens Mauwese meer bezig dlenen te houden met de constructle van leersiluatles op basls van leermodellen uit de psychollogle on op basls van meer fundamentele onderwlJsresearch. Het zorgvildig onderzoeken van relatlas tussen studentkenmerken, leerongeving en leerresultaten, on onderzoksmethodologle die ptitude-treatment-Interaction (ATI) wordt genoend (Cronbach Snow, 1977), Is hierbll een noodzakellyke, mar geen volloende voorwarde tot succes.

Het benadrukken van de positle van de onderwij skunde als tussenschakel fussen leerpsychologle en de dagelljkse praktljk van het onderwijs is nlet nleuw. Glaser (1976) refereert in dlt verband aan de opvattingen van Dewey, neergeschreven in 1900, warin deze het heeft ower de noodzaok $v a n$ een "Ilinking siclence". Glaser benadrukt zelf het ontwerpaspect (deslgn) van de onderwljskunde als het kenmerkende wan de lntermedlaline posittle van de onderwljskunde. Het probleem is echter dat de onder IJskunde den de onderwlJ spsychologle geen dlrect toepasbare, enduldig interpireteerbere modellen fer beschllkking hebben. De wllze warop vakgebleden als bljvoorbeeld de lectrotechnlek en de werktulgbouwkunde zlch met constructieproblemen bezlghouden op basis van binnen dle vakgebleden ontwikkelde expertise en gebrulk makend van inzlchten ult de wiskunde en natuurwetenschappen verschllt dan ook aanzlenllljk van de sltuatle war in de onderwljskunde zlch bewindt.

Uit de onderwlj skundige Ilter atuur kant een tweetal aanbevel ingen naer voren, dle deze sltwatle kunnen veranderen.

Al lereerst de alanbevelling on meor fundamenteel onderzoek to doen naar het proces, dat centraal staat In hot onderwljs, namelljk hot leren wan studenten. Met mane onder zoekers met een achtergrond in de psychologle, zoals Bruner (1966) en Kerlinger (1977) beplelten een dergeII Jke benader Ing.

In Nederland hestt crombag (1978) In oun provocerend essay dit pleidool voor en Intenslevere anpak van onderw ljsproblemen verder ultgewerkt. HIJ stelt, dat onderwlJsonderzoekers zoveel mogelljk tija dle- 
nen te besteden aan fundamenteel, beschr lJvend en vorklarend onderzoek naar het leren.

In de onder zoeksactivitelten van Nederllandse onderwly sresearchcentra Is de aandacht voor meer fundmenteel onderzook dulldelljk zlchtbaar, met name op het terrein van het onderzoek naar de hogere oognitleve vaardigheden "leren problemoplossen》. Vermeld kunnen hiler worden het onderzoek van Crombag e.a.(1972) naar het opzoeken van casuspositlies In Juridische vakliteratuur, het leren oplossen van technische problemen in Twente (Mettes \& Pllot, 1980) en In Elindhoven (Vaogs, 1975), het onderzoek wan Breuker (1981) naar het functloneren $v$ an het suantIsch geheugen, onderzoek op het gebled van het probleenleren aren de Rljksuniversitell Limburg (Schmldt, 1982) en onderzoek op het gebled van medisch probleemoplossen (Claessen \& Boshulzen, 1981; Gerrltsma \& Smal, 1982).

De tweede aanbeveling komt met name van orlticl van onderwijskundig evaluatle-onderzoek: er dient meer aandacht te worden besteed aan een adequate beschrljuing van wat zlch in het onderwlJs afspeelt. Onderwijs zou daarblj nlet beschouwd moeten worden als een "black-box", warover men slechts door nauwkeurlg meton aan In- an ultgangen te weten kan komen welke gedragselgenschappen het systeem heeft. Elsner (1972) bepleit en betere beschrijuing vanult het argument, dat elndtoetsresultaten over het algemeen te welnlg predictlove warde hebben In onderzoek. Lelnhardt (1980) benadrukt het belang van een betere meting van het onderwljsleerproces (educatlonal treatment) on gevonden verschilllen in toetsresultaten beter te kunnen verklaren.

Snow (1974) merkt op, dat de lezer ult de weolheld van onderwlJskundlg anderzook slechts zelden een beeld krljgt wan de leersltuatle van studenten (welke activitelten worden ondernomen? Welke rol speelt de docent? etc.). Hil bepleit het opnemen van meer (en andere) gegevens in onderw lJ skundlg onder zoek. Dat is van belang on de ecolloglsche vallditeit van onderwljskundig onderzoek te vergroten, wen term die snow ontleent aan de psycholoog Brunswlk (1956). De Klerk (1979) vat dit begrlp als volgt semen: een experlment is ecologisch vollde ols het wordt ultgevoerd In een "settling" dle In hert dagell Jks leven ook voor andere dan uitsluitend research-doelelnden vaorkomt. Ean setting is een plaats (bljvoorbeold de schoolklas) war de lin het onderzoek botrokken personen in verschlllende rollen (leerlling, leerkracht, ouder) gedurende een bepaside tljd (lesuur) bepaalde activitelt verrlchten (bestuderen van een les of het beantwoorden ven toetsvragen). Plats, rol, tijd en activitelten zijn elementen van de setting. De ecolo- 
glsche vallditelt heeft betrekling op alle elementen wan de setting".

In het algemeen kan men constuteren, dat doze tweode aanbevelling ver minder gevolgd wordt den de eerstgenoende.

Een belangrljk fundamentel problem, dat hlerblj een rol speelt is het beschrlJven en metbear maken van de onderwlJsleersituatle.

Eon andere verklaring vomt welllcht ook het gegeven, dat het boschrljven van onderwljsleersltuatles zlch vooral voordoet blinnen de context van evaluatle-onderzok. De ontwlkkellingen op dit gobled In de Varenligde staten tonen aan, dat ovaluatle van het onderwlys tot een $\mathrm{min}$ of meer autonoom werkgebled is ultgegroe!d, dot zlch rlcht op het beantwoorden van de vraag; vol doet het onderwljsprograma, zoals dat ontwlkeld is, an de doelstellingen van dat programa?

Do. Ilteratuur over evaluotlemodellen, die hlerblj behulpzaam kunnen zijn, levert en rljk geschakeerd beeld op. Van der Klauw L Lubbers (1979) on Gyseleers (1982) geven cen goed overzlcht wan de belangrljkste modellen. Er bestaan grote werschlllen in benaderlng, dle met name samenhangen met wie de opdrachtgever is (overheld, bestuur, dacenten), wat de ultelndelijke doelstelling van de evaluatlevraag is (moet het programa worden gestopt, mogellJkheden tot verbetering, etc.) an walke taak de evaluator heeft (verzamelt hlj Informatle of becordeelt hlj). Toch is er en frappante overoenkomst tussen de modell ien in het ultgangspunt dat zlJ hanter ten arnzlen van de relatle tussen de evaluator en datgene wat geovial veerd dient te worden. In de meeste modellen wordt de evaluator beschouwd als lenand, dle onderzoekt of datgene wat anderen ontwikkeld hebben an de doelstelling voldoet.

De ontwlkkelling van deze denkbeelden heeft in de Verenlgde Staten plaatsgevonden in een cultureel en polltiek klimat, war in "accountabllity", dit Is verantwoordingspllcht ten anzlen van de besteding van mlddalen, een steeds sterkere rol speolt. Het ontstaon van commerclële ewal uatle-instituten met tientalien stafleden geeft aan dat velo onderwljskundigen hun andacht storker rlchten op het evalueren wan andermans werk, dan op het leveren van een directe bljdrage an de constructlo van onderwlJsprograma's. Howel het evaluatlemonderzoek op het gebled van analysemodellan on instrument-ontwlkkel Ing belangr ijke resultaten heoft gebookt, heeft deze benadering zlch te weinlg gerleht op hot Inzlcintellik maken van het onderwlJs-leerproces, zoals ondermeer door snow (1974) wordt benadrukt.

Het hlerne te rapporteren anderzoek kan in het Ilcht van de hlervoor gep latetste opmerkingen over onderwijskundlg onderzoek nlet worden be- 
schoumd als fundamentel onderzoek, maer veeleer als oen pogling de constructio en implementatie wan een onderwlJsprograma to beschrlJven. Daarblj is een rulm aantal bromen en meetlnstrumenten gebruikt on zodoende een genuanceerd inzlcht in het onderwijsleerproces te verkrljgen. In dit verslag zal voorts andacht worden besteed aan de $1 \mathrm{j}$ ze warop de informatle dle werd verzaneld, al dan niet geleld heeft tot verander Ingen in de onderwlj sop.zet.

Het benadrulkken van het constructlo-aspect heeft belangrljke consequentles woor de wije warop het onderzoek werd ultgewoerd. In klasslek evaluatle-onder zook heeft de onderwljskundige geen verantwoordeIIJkheld voor de kwallitelit van het aangeboden programa. In dit proJact makkte de auteur deel ult van het team, dat verantwoordelljk was voor de opzet en uitvoerling van het betreffende onderwljsprograma.

De brulkbaarheld van onderzoeksgegevens voor te nemen matregelen In het onderwljs, heeft mede hlerdoor de voorrang gekregen boven een abstract wetenschappel IJke benader ing waar in het tussentilds bekend worden en gebruik maken van onderzaeksresultaten eerder als een minder wensel ljke Interferentle met de onder zoeksopzet wordt beschouwd.

Voorts was het onderwljsprograma, warop het onderzoek betrekking heeft geheel nleuw. De onzekerheden over wat haalbaar en verantwoord zou zijn in een dergelljk programa heeft duldelljke sporen in het onderzoek nagelaten, waraam ook aandacht geschonken zal worden.

De vraag of in een dergell ljke context wetenschappellyk verantwoord onderzoek kan worden verrlcht, drlingt zlch natuurlljk op.

De beantwoording van dle vraag hangt ten nauwste samen met de opvattingen, dle lemand heeft over doelstelling en methode van atenschappelljk onder zoek.

De auteur is van mening dat cen zorgwuldige beschrlJving van de construct le van een onderwijsprograma binnen een realistische sltuatle, warlln de werkell Jkheld grote beperkingen oplegt an de onderzoeker (maar cok nleuwe mogelljkheden bledt) een bljdrage kan leveren an het verkriJgen van beter inzlcht in onderwlJsleorsituatles.

Zorgvuldighold in aanpak on het vergroten vam inzlicht zijh twee belangrlljke kenmerken van wetenschappel IJk werk. Dle opvattling met betrekk Ing tot toegepast onderwijskundlig onderzoek slult naw an blJ een benadering, dle in de recente llterafuur bekend staet als "IIIumlnative evoluation". Parlett \& Dearden (1981) onschrljven als centrollo doelstelling van deze benaderling: "The task is to prowlde a comprehensive understanding of the complex reallty (or reallitles) surrounding 
the program: in short to llliminate" In hls report, therefore, the ovaluator alms to sharpen discussion, dlsentangle complexitlles, isolate the signiflcant from the trivial, and to ralse the level of sophlistication of debate."

Wet hilerna te rapporteren onderzak is in dubbel opzlcht exploratief: allereerst door het klezen van de hlerwoor aengedulde werkwlJze. Daarnast ok andat ale whorlyze wordt toegepast in onderzoek, war In een door onderwij skund lgen weinig onderzochte onderwils loersiltuatie, namell IJk neen stage, als onderwerp gokozen is.

De hlervoor gestelde wraag naer de wetenschappelljkhelld van dit onderzoek han cok op emplrische iljze beantwoord worden, namelljk door het voorleggen $v$ an het onder zoeksverslag aan een wetenschappelljk forum, hetgeen in ze rapportage gebeurt.

\subsection{Stages.}

Hoewel In vele unlversitalre en hogere beroepsopleldingen stages in het onderwljsprograma zijn opgenomen, is het opvallend dat de onderwilskunde welnlg aandacht aan dit fenomeen besteedt. Mertens (1977, 1981), die zlch blj wiljze van ultzondering ultvoerig met dit onderwerp heoft bezlggehouden, zlet als een van de mogelljke oorzaken het gegeven dut stages zoveel overeenkomsten vertonen met het leren zoals mensen dat $1 \mathrm{Jj}$ dens hun hele leven doen. Het leren van alledag is min of meer toevallig on weinlg gesystematlseerd, fermill het leren dat plaatsvindt In en onderwljsorganlsatle te typeren valt als systematisch, nlet toevallig, maar gepland. De onderwljskunde houdt zlch, volgens Mertens, mlsschlen wol het l lefst bezlg met onderwljsproblemen warvan het gaccepteerd is om ze te systematiseren en te rational iseren. Mortens (1977) betoogt achter, dat in princlpe stages eveneens onderworpen kunnen worden can de kernvragen in een onderwlyskundlge analyse: wat zljn de doelen, welke mlddelen staan or ter beschlkkling en op welke wijze kan worden vastgesteld of de doelen cok berelkt zljn.

Niet alleen de onderwljskunde is in gebreke gebleven om aandacht te besteden an stages, mar cok de onderwllsinstellingen dle stages in hun programa opnemen. Mertens (1981) trekt die conclusle ult onderzoek nar het wel en wee van stages in het technisch onderwils, ter- 
w II Abrahamson (1982) +1jdens an symposlum over de theoretl sche basis van het ontwerpen van $k / \mathrm{ln} l s c h e$ stages, de sombere constater lng doat "the clinical clerkship is a classlc example of a ritual in modical aducation and thus not ever to be challenged or axamined, let alone moditlled!n

Well lcht kan dit gebrek an aandacht historlsch verklaard worden ult de wijze warop, tot an het begin van deze ouw, opleldingen tot een professle georganlseerd waren, namelljk volgens een meester-gezel leermodel, warblj de gezel in de loop van een (lange) leerperlode de praktische bekwamheden van de neester leerde. Hoewel in een dergelijke leerrellatle ongetwly feld weel geleerd kan worden onder gunstige conditles, moet men echter constateren dat alt model miet werkt in de huldige samenleving, dle gekenmerkt worden door een massale vraag naar professionele krachten en door eem explosieve groel van kennis en technleken dle ara en professle ten grondslag Ilggen.

1.3.1. Een anschrlJving van het begrlp "stage".

Mertens (1977) anschrljtt een stage als een bultenschool se leerperlode, dle plootsvindt op instigatie van en onderwljsinstituut. Analoog aan de vrasg, dle Wardenar (1980) stelt ten aanzlan van scrlptles, kan men zllch afvragen op welke wijze men een stage onderwljskundig dlent te karakterlseren in termen van didaktische anaiyse. Als kader kan daarblj het didaktisch analysemodel van Van Gelder cDe Corte, 1976) gebrulkt worden, zle figuur 1-1. Dit model bestabt ult de volgende, met el kaar samenhangende, elementen:

1. De doelstell Ingen van een onderwij sprograma.

2. Een anschirljving van de beginkenmerken van studenten, docenten en de onderwljssltuatle.

3. De onderwijsleersituatle, onder te verdelen in:

3.1. keuze on ordening van leerstot,

3.2. didaktische werkvormen,

3.3. leeractlvitelten door de student te verrlchten,

3.4. to gebrulken onderwijs- en leermilddellen.

4. Evaluatio van leerresultaten het onderwljs. 
Flguur 1-1: Dldakt lsch analysemodel wan Van Gelder.

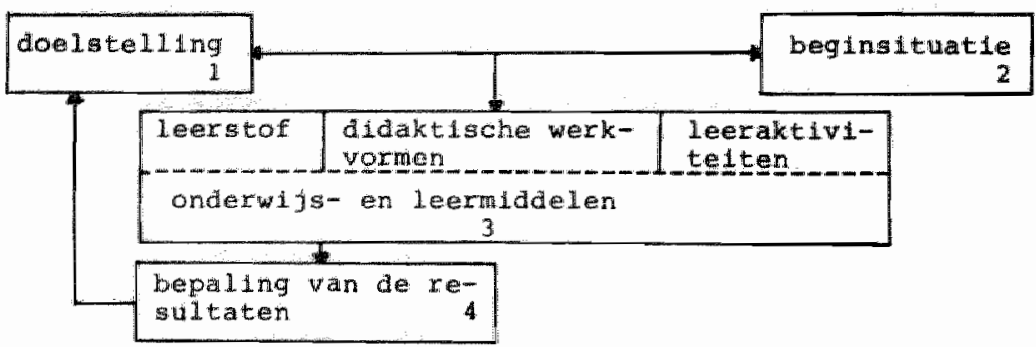

De onduldelljke positio van stages in het onderwljs bllJkt, wanneer men opvattlingen over wat een stage is, poogt to plaatsen in dit nodel. Sormlgon beschoumen een stage primair als ean doelstelling van het onderwljs: de student dlent +IJdens ziljn oplelding in praktische situatles to functioneren.

Anderen zlen de stage als evalluatle: de praktlJksltuatle wordt vooral beschouwd als toetsing, on to zlen in hoeverre de student op bas ls van het voorafgaande onderwllys in staat is bepalde prakt Ische taken uit te voeren.

Weor anderen, waronder Mertens (1977, 1981), zlen de stage als een onderwsleorsituatle, war In onder Invloed wan de praktljk lets gelleord wordt.

Naar de opvattilingen van de auteur ken men en stage het meast vruchtbaer karakterlseren als on planmatig opgezet onderwlJsprograma of cursus. Dit Impllceert det het gehele model van de didactische analyse arop van toepessing is. De argumenten woor dle opvatting zlJn praktlsch van eard: men kan zllch ten aanzlen van en stago namel ljk alle vragen stellen, dle overeenstemen met de verschilliende componenten $v$ an hot dldaktisch analysemodell: warom een stage, wat zljh de relovante beglinkenmerken, welke leermiddelen en learervaringen zljn boschlkbaar en op welke wijze wordt leeractlvitelt geävalueerd? Ulteraard ken de nadruk, dla gelegd wordt op de beantwoording van bepaalde 
wragen verschlllen, mar dat verandert nlets aen het uftgangspunt, dat al deze vragen relevant zlJn.

Het stellen (en beantwoorden) van dezelfde vragen ten aenzlen van stages als ten aanzlen van andere onderdelen van en onderwijsprograma kan bovendlen als bljkomend voordeel habben, dat al ternatleve moge$111 \mathrm{Jkheden}$ voor stages bespreekbaar worden. Daarmee kan den de gewoonte doorbroken worden on stages alleen in tlJdsduur, maar nllet naar Inhoud a an de rest wan onderwlJsprograma to relateren.

Het woorafgaande samenvattend kumnen we en stage beschouwen als een cursus, dle gekenmerkt wordt door het gegeven dat het gaat on buitenschooll se leerper lode.

Wat een dergellike cursus onderscheldt van andere onderdelen van een curriculum is de plaats dle de "praktlJk" Inneent in stage. Onder "prakt l Jk" verstaan wij de wijze waarop on de omstandigheden waronder bercepsbecefenaren hun vak uitoefenen. Gedurende stage wordt student in de praktljk geplaatst. De rol die de praktljk speeit in het leerproces van de student kan varlëren. Een stage in de praktljk bledt In principe de mogelljkheld on aan ulteenlopende doelstellingen te werken. On antal omschrljuingen te gebrulken: de student dlent kennls in de praktljk te brengen, hll dient zljn kenn Is te toetsen arin de praktijk, hij dient to loren wan de praktljk, hij moet leren in de praktijk, hlj dient praktljkervarling op to doen.

Afhankelljk van de keuze voor oen of meer van deze omschrljuingen als ult gangspunt voor een stage kan een ontwerp van een stageprograma gomsakt worden.

De keuze die Mertens (1981) doet door stages te karakter Iseren als een vorm van "experlental" of "exper lence-based" leren, warblJ het leren primair door de elgen ervarlingen van de leerlingen wordt gegenereerd, ls wat ons betreft dan ook te aljalg. Daarblj dlent aangetekend to worden, dat de grote nadruk op het elgen inltiatlef en de elgen ervaringen van studentien well lcht eerder een ulting is van de gerlinge belangstelling van onderwljsinstellingen on stages to structureren, dan van het aanhangen van voorultstrevende onderwlj sopvattingen.

Het door Mertens gerapporteerde onderzoek over het praktljkJ aar blmnen de HTS-oplelliling geeft dit ook wel aan.

Uit deze opmerking mag nlet worden afgeleld det elgen ervarlingen van studenten tlljdens een stage geen belangrlJk ultgangspunt zouden zl] In dit werbend is de classiflcatle van de Groot (1974) met betrekk Ing tot typen leereffecten, dle in een onderw lJ sprograme kunnen optraden 
relevant. Deze classificatie is voortgekonen ult oen groelend besef, dat het streven nar anschrijulng van meetbare gedragsdoelstelIIngen antal belangrijke mogel ljke ultkonsten van leeractiwitelten bulten het gezlchtsweld van de onderwlj smaker plaatst. De Groot onderscheldt vler hoofdtypen van leereffecten, dle ontstain ult oen twedimensionele classiflicatle. Een ander is wergegeven in figuur $1-2$.

Flguur 1-2: Typen leereffecten volgens de Groot (1974).

UNI VERSEEL

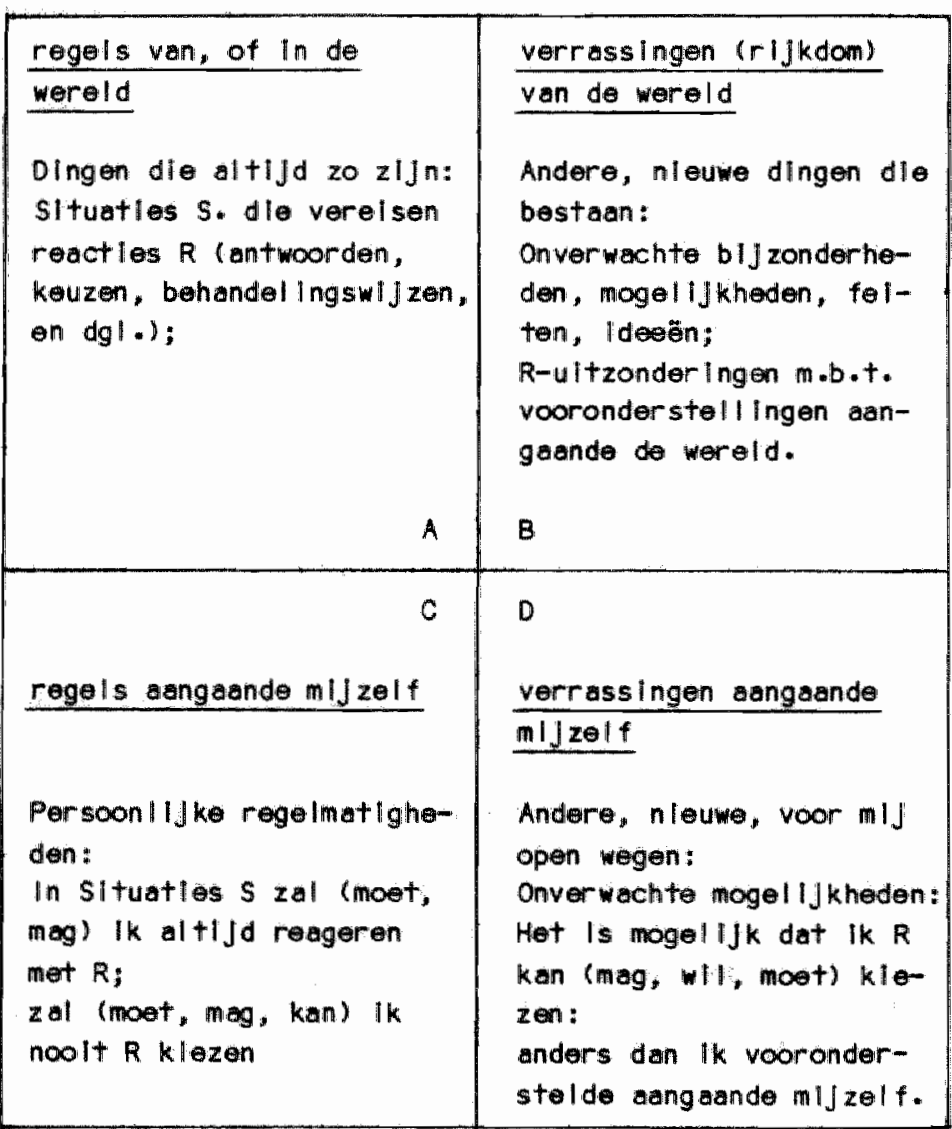


Veel loereffecten van stages zullen passen in de cellen B, C en D. BIJ stages gaat het on het laten zlen dat regels ultzonderingen kennen, det de praktljk niet zo rechtlijnig is ols de theorle. De mogellikheden van en student on ult to groelen tot een $\mathrm{krl} l \mathrm{l}$ lsche en creatleve beroepsbeoefenaar hangen samen met het optreden van dergelljke leereffecten.

Het bevorderen van het optreden van dergelljke leereffecten en het vaststellen of die leereffecten optraden zlJn twee probleenvelden die binnen de onderwijskunde relatief geringe bellangstelling hebben gewekt. Naar hum aard zijn de leereffecten onder $B, C$ en $D$ minder toegankellljk voor de benader lngswljzen die zlch met name hebben gerllcht op het analyseren en bevorderen van leereffecten zaals onder A aangegeven. Veelal is men angewezen op de rapportage door de lerende zelf. Dat neent niet weg dat wooraanstaande denkers over het onderwl]s zoals Dewey (1916, 1939), Bruner (1972) en Rogers (1969) op het belang van dergelljke leereffecten hebben gewezen. Een onderwljstechnologle, die zlch rlcht op het toepasbaar maken van deze ldeeeñ In het Hoger Onderwils bestat exhter milet.

In het hlerna te rapporteren onderzaek wordt de totstandkam Ing van ean stage voor vijfdejaars medische studenten in de hulsartspraktljk beschreven.

Vanaf het al lereerste begin is daarbll getracht op bas is van ratlonele argumenten te komen tot een cursusontwerp. Het beschrljuen van dat ontwerp en de wiJze warop dit onderwljsprograma feltelljk werd gereallseerd vormen de twee belangrljkste doelstellingen van dit onderzook.

1.4. Stages in het medisch onderwijs.

Het directe contact met de latere beroepspraktljk gedurende de medische oplelding makkt al sinds de audheld deel ult van de artsopleilding: wle zlch tot arts wenste to bekwemen zocht benende geneesheer an wan hem zowell practische als theoretlische bekweanheden to ren. Volgens de Arablsche overleverling verzamelde de Islamitische wiJsgeer en geneesheer Avicenna (980-1037) zlln leerlingen in concentrlsche clikells rondom een patlểnt en llet hlj vervolgens de minst ervarenen oen diagnose stellen; wanneer dle er nlet ultkwamen mochten de 
meer ervarenen net proberan, warna del gelleorde zelt de ulteindell Jke concl usle formulerdo.

Aan het beglin van de twintigste eeum ontstonden de medische curricula, zoals lo thans in aangepaste vorm In veel landen voorkomen. Het zogenaande Flexner-report (Fliexner, 1910) over het medisch onderwijs in de Verenigde staten speelde daarblj een belangrlJke roll. In dat rapport werd een schelding tussen het pre-kllnisch on het kllnIsch onderwijs voorgesteld; in de pre-klinllsche perlode dlent de student wetenschappellJke prlnclpes leren kennen, dle hll In de kllnische perlode daarna leert toepassen in prakillsche situatle. Zo ontstond een medische oplelding, war In de klinlsche fase, bestaandie ult en antol stages op afdelingen ven en groot zlekenhuls, losgekoppeld was van een daraan voorafgaande pre-klinlsche fase. De praktische perlode heeft hlerblj als prlmair doel het voorberelden vam de student op de beroepsultoefening als arts.

Elrlck (1967) vat de belangrljkste elementen van deze algemene doelstelling van het $k \mid$ Inlsch onderwijs als volgt samen:

"Probably the single most Important sklll needed by the compentent physiclan is the ablility to establish an effective professional relatlonshlp with the patient.(.......).

The second important clinlcal sklll is to obtain clinlcal information from the potlent or others.(......).

The third sklll, clinlcal analysis and synthesis, Involves the abllity to assemble clinical information into meaningful, sclentiflc form to onable formulation of the patient's problems; to work out a carefully planned, Indlvidual dlagnostic program; and to synthesize clinlcal and dlagnostic data and arrive at a definito dilagnosis and therapeutic program. Thls also includes recordling all data in proper written form and, when necessary, presenting the materlal orally in an effective manner.

In addition to the 3 primary clinlcal skllls, there are certain attltudes and behavlour characterlizing the role of the physlclan. His majom function $\| s$ to understand and help hls patlents, and not to Judge them. (.....).

He behaves toward patients as well as colloegues, students and nurses with the dignity, the tact, the respect, the serlousness, the patience, the discretion, and the integrity to be expected of a gentleman and an Individual who deals with intimate personal problems and matters of 11 fe and death. (.....).

Another Important aspect of the physlclan's role is helping patients achlowe and walntain optimum health. (.....). 
Finally, there are 2 importent hablts characterlstlc of the effectlve physlclan, the habit of excellence and that of constant self-educatlon."

Byme cohen (1973) geven op basis wan een onderzoek naar onderwijsactivitelten in two "teaching hospltals" van do universitelt van Toronto overzlcht van leeractivitelten die door studenten tljdens kIInlsche stages worden ondermomen. ZIJ onderschelden 10 leervorimen:

"Observatilonal learning. Thls takes place as a result of observing staff members and/or house staff members dolng procedures or presenting cases at rounds where there is no assumption of performing the procedure by the observor clerk or attenmpting to repllicate the instructor's behavlour during the clerkship.

Modelling llearnlng. Thls takes place in the process of forming procedures or presenting cases in essentlally the same way as those performed by physlclans whom the student has observed.

Trial and error learning. Thls takes places in the process of performIng tasks and subsequently changling technlques on the basls of seltassessment of their effectiveness.

Instructed learning. Thls results fram engaging in activitles such as performing procedures and presenting cases in the presence of an Instructor, who subsequently comments on both the good and the bad aspects of the clerk"s performance.

Questlon-answer learning. Thls takes place when the clerk is obliged to use hls knowledge, perceptlion, memory, and exper lence to respond to questions that are put to him.

Inquiry learning. This takes place in the process of the clerk asking peers, house officers, and/or staff members questlons for such purposes as clarification, el aboration, and information.

Dldactlc learning. This takes place as the clerk llstens during didactic presentations, rounds, seminars, discusslons, and the Ulke.

Selt-learning. This takes place in the process of unsupervised, discusslons lth patlents, reading llbrary books and perlodicals, vlewing audiovlsual materlals and charts, and using other sources that the clerk explores on his own initlatlve.

Practlice learning. Thils takes place in the process of repeating procedures (for example, setting up intravenouses; dolng lumbar punctures, epidurals, and spinals; taking arterlal blood; dolng physlcal oxaminations; and prescribling therapy) untll a sense of mastery is acqulred. Team problem solving "n (hlervan wordt geen anschrlJwing gegeven). 
In het onder zook werd eveneens nagegaan well ke leorvormen door studenten tiljens stage geprefererd worden. De resultaten wezen ult dat actlleve leerwornen (Instructed learning, practlce learning en team problem solvingl het meest geprefereerd werden en de passleve leerwormen (didactic learning, observational learning) het minst. Byrne a Cohen (1973) slgnaleren, daf in de onderzochto stageplaatsen een sterke varlatle in onderwijslearactlwitelten woorkwam. Deze conclusle kan zeker in zljn allgeneonheld getrokken worden ten aanzlen van stages in het thedisch onderwijs. Het zou in het kader van deze inleiding te ver voeren an in te gaan op de merltes van de vele varlanten, die er blnnen de medische oplelding bestaan, en op de specl fleke doelstellingen dle daraan ten gronds lag Ilggen.

Sinds de zestlger Jaren heeft zlch in het medisch onderwlJs antal ontwlkkelingen voorgedaan, dle van invloed zlln geweest op de doelstellingen op de vorm en Inhoud van stages in de medlsche oplelding. Die ontwlkkellingen komen woort ult de groelende twljfel "of gedurende kllnische stages in grote zlokenhulzen de student voldoende kan worden voorbereld op de lotere beroepspraktijk. Dle twljfel wordt ondermeer ultgesproken door Georgo Mlller (1962), Elrlek (1967) en Engel (1971).

Elrlck (1967) vat het probleon als volgt samen:" "The unlversity teachIng hospltul has become center for clinllcal research and a base for research-orlented medical staft; other prime concerns are with the care of complex and rare diseases, ith eplsodic, crises-orlented medical care, and with the training of speciallsts. In this setting the teaching of cllnlcal methods and patient care to medical students easily becomes a subsidiary activity."

In twee rlchtingen zlln oplossingen voor dit probleem gezocht.

Allererst zlJn op vele plaatsen programmis ontwikikeld, die ton doel hebben in thet aan de stages voorafgaande onderw IJs de student beter op het werken in praktische settling voor te bereiden. In Nederlland zijh de zogenaando Junlor-co-ass istentscheppen inlervan en woorbeeld (z) onder wer ven der Lugt \& Glsolf, 1972). Daarnaast kan gewazen worden op het SkIIIslab-programa van de RIJksuniversiteit Limburg. In $\mathrm{d} l t$ programa leren studenten $+1 \mathrm{~J}$ dens do erste vler studllojaren de oersto beglinselen van medische on soclalo vaardigheden, d lo van bel ang zIJn voor de ongang met patlënten in hun verdere studle en hun latere beroepsultoefening. De Inschakelling van audlo-v/suele middelen (klleurenvideo) en de ontwlkkeling van llerlel simulatlevormen (Gerritsma \& Smal, 1974, 1982) hebben de mogelljkheden on relatlef onervaren stu- 
denten medische vardigheden te laten cefenen sterk vergroot. Een bellangrlJk bljkomend voordeel wan deze ontwlkkelling is, dat de overlast woor echte patienten op deze wijze kan worden Ingeperkt.

De twoede rlchting war in gezocht is on de geschetste problemen in het klinisch onderwijs het hoofd te bleden is de ontwikkelling van stageprograma"s in nlet-speclallstische settingen. In de Verenllgde Staten $z$ IJn in de zeventliger Jaren en antal programm"s ontwlkkeld, waar in studenten een groot deel van hun praktlsche oplelding doorbrengen in comunity health centers (well werken hier in hulsartsen semen met specialisten en paramedicl). Deze programa's ontstonden vooral in dunbevalkte geblleden, waar cen tekort aan in de algenene praktijk werkende artsen optrad. Noorbeelden van dergelljke programi"s zljn het Upper Peninsula programa van Michlgan Stato University (Rlchards Q.a., 1978) en het Rockford programma van de University of IIIInols (Barr e.a., 1976). Op andere platsen ontstonden programmals, war Im studenten gedurende een kortere perlode, varlerend van éen tot zes maanden in de erstelijnsgezondheldszorg stage lopen. Voorbeelden van dergelifke programa's ziJn onder meer University of North Carollina (Frledman e.a., 1979) en het WAMI programma van de University of Weshington (Schwarz, 1978). Dok In Engeland en Nederland zllJn stages in de hulsartspraktljk onderdeel gaan ultmaken van het mediseh curirlcul um.

De ontwlkkelling van een dergelljk stage-programa aan de focultelt der geneeskunde In Mastrleht zal in de navolgende hoofdstukken centraal staan. 


\section{Hoofdstuk 2}

\section{De ontwikkeling van het Praktisch Medisch Onderwijs in de Huisartspraktijk}

2.1. Inlolding.

In dit hoofdstuk wordt de ontwlkkelling van het dldakt Isch model van de stage in de hulsartspiraktijk beschreven. In paragraaf 2.2. wordt de stage geplaatst tegen de achtergrond van het currlculum en worden de algamene ultgangspunten beschireven.

In do nawolgende paragrafen worden de doellstellingen anschreven en de elementen van de onderwllj sleersltuatle.

Paragraf 2.5. beschrlJft de werving en voorberelding van de hulsartsien, de lls stageverlener optreden.

In de beschrljuing wordt aendacht geschonken aan de overweglingen die in het feltelijke planningsproces naar varen kwamen, eventuele onderWiJskund lge opmerklngen hlerblj en de ultelndelljke keuze dle In het stage-ontwerp gedaan werd. Onderwils is een proces dat zlch voordoet binnen an antal randvoorwarden, warvan de factor tijd zeker nlet de minst belengrljke is. Vandaar dat aan de chronologie van het planningsproces ook en ige aandacht geschonken wordt.

2.2. Hat PMOH in het Mastrlchtse currlculum.

In 1972 publicoerde de Comissio Voorberelling Medische Facultelt Maestrlcht (1972) aen stuk In Medisch Contract, getl teld "Basisfllosoflle Achtste Modische Faculteltit. In deze schets wordt sterk gepleit voor en facultelt, dle har doelstellingen ontleent aan de gezondheldszorg. Daer wordt nog an toegevoegd dat speciale aandacht en onderzoek besteed dient te worden aan de oplelling van artsen voor het oersto ochelon.

Unlek voor deze nleuwe facultelt was dat gestart werd vanult on onderwlJ skund lge conceptle en dat een aental onderwlJsprinclpes werden 
vastgelegd. Deze werden nader ultgewerkt In het Raamplan 1974 (MFM, 1974), war In de contouron van en currlculum worden geschetst. In deze onderwijsanpak wordt de relatie theorle-praktijk in de medische oplelding opnleum doordacht. Gekozen werd voor on aanpak warblj de student gedurende zljn gehelle opleldingstljo veel intenslever de rellatle tussen theorle en praktljk kan ervaren. Het in de praktljk brengen van de princlpes werd vanaf 1974 in hat medisch curriculum zlchtbaar, al bleck dit nlet eenvoudig. Gezlen de arzelling in regeringskringen on de erder aan Limburg gedane toezeggingen met betrekking tot het stichten van een RIJksunlversitelt daadwerkellik te effectuoren, werd in 1974 overhaast gestart met het opnemen van studenten. Dle snell le start betekende echter dat or welnig tljd was geweest om de contacten met de gezondheldszorg in de reglo op een nlveau te brangen, warop vruchtbare intensleve samenwerking in het onderwlys mogellyk wordt. De consequentle van dit allies was, dat de oerste groepen studenten in hun onderwiJs minder betrokken waren blJ de gezondheldszorg, dan de plomlers van het onderwlJs in Maastrlcht oorspronkelijk voor ogen stond. Nlettem in was en is de kennllsmaking met de praktijk van de gezondheldszorg in de oerste Jaren van het curriculum duldellJker aanwezlg dan in andere medische opleldingen in Nederland.

Het curriculum anvat zes studiejaren. De eerste vier studiejaren zlJn opgebound ult blokken van zes weken rond een centraal thema. Niet de disciplines, maar problemen vormen de basis warop studenten zlch de kennis en vaardigheden elgen maken, dle noodzakelljk zljn om later in een veranderende beroepsprakt IJk te kunnen functloneren. Het onderwIJs. +1 jdens de blokken In de erste vler studlejaren wordt nlet gegeven door mlddel van colleges, maar aangeboden door middel van en blokboek. Dit boek, dat wordt samengesteld door een multidisciplinalr team van docenten, kan beschouwd worden als het spoorboekJe voor de studen*en gedurende het betreftende blok. De kern wordt gevormd door een varlëteit van probleemstell Ingen met betrekkling tot het blokthema. Daarneast bevat het IIteratuursuggestles, toellchtingen op het thema, 11.Jsten net deskundlgen, dle geraadpleogd kunnen worden, tIJdschema's etc.. In groepen van 8-9 studenten analyseren stiudenten de aangeboden probleamstell Ingen. Ze worden daarin begelelld door een staflid. In de loop van viler studlejaren werkt de student aan ongeveer 300 problemen, die veelal gerellateerd zljn aan de praktljk van de gezondheldszorg. Een analyse van het probleenaanbod in het currlculum van 1978-1979 geeft aan, dat rulm de helft van de aangoboden problemen gesiltueerd is In de hulsartspraktlJk (Snellen, 1983). In het currlculum wordt ver- 
spreld over de earsto wer Jaren vel aandacht besteed aan de tralning van medische vaardigheden in het zogenaumde Sklllslab-programa. UItvoerlger informatle ow het curriculum kan men vinden in schnidt * Bouhuljs (1980), Schnldt (1978), Bouhuljs (1978), Imbos \& VerwlJnen (1978).

De lautste twee studlej aren bestaan uit cen aantal stages in de praktHk van de gezondheldszorg. Het Praktisch Medlsch Onderwlls in de HulsartspraktlJk (PMOH) is hlerin als werplllchte stage wan dr le maanden in het vijfde studlajar opgenomen. De rulmte voor en dergelljke lange stage is gecreäerd door de andere klinische stages van kortere duur te laten zlJn, dan aan andere Nederlandse facultelten gebrulkoIIJk Is.

Alvorens gen gedetall leerd overzicht geven van de doelstellingen en de ultwerking daarvan In oen onderwlJsprograma is het noodzakellJk lets te zeggen over do plats van het PMOH lin het medlsch onderwlJs. Een stage van dr lo maanden in do hullsartspraktljk is Imers in Nederlland cen in de meeste andere landen unlek. Inmlddels is de verwachting dat cok andere facultelten rulmere plaats aan do hulsartspraktljk in het currlculum zullen gaen toekennen. Daarmee is i an erste antwoord gegeven op de wraag warom lin Maastricht drle maanden In de hulsartspraktljk worden doorgebracht door all le studenten in het baslscurr|culum: en algemene herorlëntatle op de plaats van de eerstell Jnsgezondheldszorg. gepaard aan de ontwlkkelling van de hulsartsgeneeskunde als unlversltair vakgebled. In tabel 2-i zijn de stageactiviteiten op het gebled van hulsartsgeneeskunde in hot basiscurrlcuI un aan andere Nederlandse facultelten samengevat. Duldelijk lis dat die aktivitelten qua onvang on qua plats in het curriculum afwljken van de Maestrichtse situatle. Het aangeven van "algemene tendentla". is echter neuwell ljks en bevredigend antwoord op de vraag, warom In Maasitrlcht gekozen is voor dr lo maanden PMOH.

Een mear gedetall leerde beschouwing over deze kwestle dient te starten met de Baslsfllosoflo van da Achtsto Medlsche Fakultelt (1972), warln nadrukkollJk geplelt wordt an speclalo andacht te schenken aan de oplelding van artsen ten behoeve van de eorstell J insgezondheldszorg. Dle orlentatie kont voort ult an groelend besef dat er in de ontwikkelling van de geneeskunde sprake is van een zekere tegenstrljulgheld: de ontwkkelling von deel speclallsatles en superspeclall smen maakt het an de one kant nogellijk oplossingen te vinden voor medlsche problemen, dle voordlen onoplosbaar waren, maar drelgt aan de andere kant de aandacht 
voor "normalle" medlsche probllemen, zoals dle met name in de hulsartspraktljk naar voren kcmen te verminderen. De laatste tlen Jaar is meer en meer het besef doorgebroken, dat spectaculalre nleuwe ontwlkkellingen op het geblied van de geneeskunde nlet zonder meer hoeven te lelden tot betere gezandheldszorg woor allen.

Tabel 2-1: Overzlcht van co-ass Istentschappen Hulsartsgeneeskunde aan 7 med I sche falkultelten In Neder land (situatle 1982/83).

\section{Duur}

Vrije Universl-

telt Ansterdam

Universitelt van

Amsterdan

RIJksuniversiteit

Gron Ingen

3 dagen

2. weken

Rijksunt versitelt

Lelden

2 dagen

2 weken

Kath. Unl versitelt

NI Jimegen

$$
\text { it dag }
$$

4 weken

Erasmus Univers -

tellt Rotterdam

3 weok

RIJksuniversitelt

Utrecht

\section{Plaats in het curricul um}

zes de jaar

zos de jar

v lerde Jaar

zesde J aar

$v$ lerde/vijfide Jaar

zesde Jaar

vierde Jar

zesde Jar

zes de Jaar

N.B. Studenten kunnen naast een verpllcht co-assistentschap ook In het kader van een keuzeperlode een stage In de hulsartspraktijk valgen.

Dok In de medische oplelding zljn er vraegtekens te platsen achter de voortgaande ontwlkkeling van deel- en super-speclall ismen; wanneer keninls en vaardigheden in het medisch vakgebled steeds sterker verkaveld 
worden In afzonder IIJke deellvakgebleden, dle leder hen herkenbare bljurage an men medisch curr icul umensen te geven, dan is de kans nlet denkbeeldlg. dat afgestudeerden to welnlg toegerust ziln om adequat problewen ven patlenten te benaderen, die zlch veell in hun verschijnlngsvorm vakoverschrl lj dend en gelintiegreerd voordoen. Dat gevar wordt nog versterkt, andat hooggespeclallseerde docenten nlet meer bereld on/of in staat zljh algemene medische concepten bulten hun directe aandechtsveld in hun onderwljs aan de orde te stellen (Engel, 1971; van der Klauw, 1979).

De IIIJ voor ken krachtlge antwlkkelling van het praktlsch medisch onderwlJs in de hulsartspiraktlJk is in eorste instantle ultgezet door Tlddens (1977) In zljn eerste Dlësrede:

Naar milln mening is thet essentleel dat de student op even grondige ljze kennis malkt met de problematiek van de hulsartsgeneeskunde als met die van het zlekenhuls. Ik ben ervan overtulgd dat de problemen, watrmee de hulsarts geconfronteerd wordt, dikwlJls vragen on oen anpak die wezenlljk verschllllend is van de benader Ingen die in de zlekenhulsgeneeskunde gekozen worden. De werkwlJze van de eerstelljnsgeneeskunde heett een elgen karakter. In ons land wordt dat orkend. Hulsartsgeneeskunde is en speciellsme met elgen opleidingselsen en en elgen Inschrljuingsreglster. Dit speciallsme heeft ochter nog nlet de status, de bemanning en de aandacht, dle het voor verdere ontwlkkelling nodig heeft. De hullsartsgeneeskunde is ongetwliffeld een van de moellijkste vormen van med Ische beroepsultoefening. De hulsarts wordt geconfronteerd met problemen ult een vrlJwel onbegrensd gebled. HIJ kan en moot in zljn werk taliljke factoren betrekken, die In andere speclalismen bulten het gezlchtsveld van de medlicus kunnen bliJven. ZlJn dlagnostlsch arsenaal is beperkt en de tlJdsdruk is valu erg groot. De bes/lssingen van de hulsarts bepalan voor een belangrlJk deell de toevoer naar de zlekenhulsgeneeskunde. HIJ is in de besto positle om een doelmatig gebrulk van hot dure zlekenhul sapparat to bovorderen."

Clj fermatlg kan de contrale positle van de hulsarts in de gezondheldszorg onderstroept worden door onderzoeksresultaten van varhoef (1979) on Bergsma (1981) dle in onderzoak naar het verwllspatroon van hulsartsen tot do conclusle komen dat respectlevelljk $13 \%$ en $11 x$ van de in de hulsartspraktljk aangeboden problemen aanlelding zijn voor een verwijzllng. Hat overgrote deel van de gezondheldsproblemen, waarbll patlênten arts raadplegen wordt den ook ultsluitend in de hulsarts- 
praktijk gezlen en behandeld.*

In het betoog van Tiddens (1977) worden in felte twee argumenten gonoend voor stage in de hulsartspraktlljk:

1. In do hulsartspraktijk vindt student varlêteit van problomen, dle afwljkt van de zlekenhulssetting: er is en bljna onbogrensde varlatle van klachten; nast groot aental klachten van meestal nlet ernstige aard kunnen ook zer ernstige problemen voorkomen; or is duidelifke verwevenheld van somatische, psychlsche en maatschappelljke factoren in het kl achtenaanbod.

2. De hulisartspraktijk kent en speclfleke werkwilze en speclflieke problemen, warmee studenten vertrouid dlenen to raken.

Hierbil springt met name in het oog het leren werken met woarloplge conclusles uit beperkte hooveel held gegevens, en vervolgens het voortdurend toetsen van nleuwe gegevens aan deze oorspronkel ljke werkhypothese.

2.3. De ontwikkeling van het stagemodel.

2.3.1. Chronologisch overzlcht van het planningsproces.

Op basls van de hlervoor geschetste historische opdracht van de faculteit der geneeskunde ten aanzlen van de gerlchthelld op de eerstellunsgezondheldszorg werd in mart 1977 aan de faculteltsraad een discusslestuk aangeboden op basis warkan het princlpebeslult werd genomen om stage in de hulsartspraktijk voor te berelden onder meer door de bereldheld van hulsartsen in de reglo te pellen am hun medewerking an dergelljk stageprograma te verlenen. De belangrlljkste punten In het planningsproces zlJn weergegeven in tabel $2-2$.

Een tweetal hoofdactivitelten dlenden onder t|jdsdruk parallel ain elkad aangevat to worden, namelljk de concretisering van stage-ontwerp en de werving en voorberelding van hulsartsoplelders. Met de term

Bergsma (1981) WIJt orop dat elders gerapporteerde elJfers van ongeveer $40 \%$ ontstaan, doordat leder herhaalconsult door de speclallst wordt opgev at als een nleuwe verwljzing. 
hulsarts-oplel lders worden de hulsartsen aangleduld, dle en student als staglilure in hun praktljk opnemen en de taken vervullen, die in paragraat 2.4.5. worden beschreven.

Tabel 2-2: Chronolog Isch overzlcht van het planningsproces.

1972 Publlicatle Baslsfllosofle Achtste Madlsche Facultelt; andacht voor oplelding van artsen ten behoeve van erstell J nsgezondheldszorg.

Juni 1974 Raemplan 1974, warlin het grondplan voor het modisch currlculum wordt geschetst.

sept. 1974 Start wan het onderwlJsprograma van de facultelt der geneeskunde in Maastrlcht.

Jan. 1977 Belang van een stage in de hulsartspraktijk wordt door Tlddens in zlJn Dlësrede verwoord.

maart 1977 Faculteltsraad neant princlpebeslult eon stage in de hulsartspraktljk to doen voorberelden.

Junl 1977 Vorming wan een reglonale klankbordgroep van hulsartsen.

sept. 1977 Schets van een stage-opzet wordt aangeboden aan de taculteit.

okt. $\quad 1977$ Multi-disclp 1 inalr docententean wordt door de facultelt bellast met de planning en ultvoerling van oen stage van drlle maanden in de hulsartspraktijk.

nov. 1978 start werving hulsarts-oplelders.

Junl 1978 stage-opzet gereed, werving van oplellers voor de earste stagegroep voltoold.

aug. 1978 Dllaktlsche voorberelding van toekomstige hulsartsinoplelders.

sept.-dec. 1978 Eerste stage voor oen groep van 24 studenten.

febr.-aprll 1978 Tweede stage voor en graep van 21 studenten.

In Junl 1977 word cen "klankbordgroep" geformeerd, waar in namens lledere PlaatsellJke Hulsartsenvereniglng (PHV) in thet werkgebled van de Facultelt ëen hulsarts zitting had. Vervollgens werd ook het Madlsch Reglonaal contrum blj dezo klankbordgroep betrokken. 
In september werd en nota over de stage-opzet ingedlend bil de faculteit (Brouwer, 1977). Nast en argumentatle en een poging de doelstellingen vaor de stage te anschrljven werd op duldelljke wlyze witengezet welke stappen ondernomen dienden te worden an ervoor te zorgen dat in een $J$ ar $+1 J d$ de noodzakel IJke woorzlenlingen tot stand konden worden gebracht. Men kan achterat constateren, dat dit stuk oen zear belangrljke factor is geweest in het succes van de planning en de ultvoering wan het Praktisch Medisch Onderwljs in de Hulsertspraktlyk. Op de inhoud van de nota zal nog nader worden Ingegaan. in oktober 1977 stelde de faculteit een plannlngsgroep PAOH in, die tot taak kreeg, de erder geformuleerde ultgangspunten nader ult te werken en ult te wceren. Deze planningsgroep bestond ult 3 hulsartsen, een gezondheldszorgonderzoeker (woormallg hulsarts), een klinlsch formacoloog, on onderwlJ skundige, een andragoloog on een student. De argumentatle woor de samenstelling was, dat or nast ean aantal hulsartsen behoefte was aan twee gedragswetenschappers, dle een rol zouden kunnen spelen blj de werving, selectle en begellelding van hulsarts-oplelders, en aan een antal vertegenwoordigers van andere capaciteltsgroepen an de inbreng van andere disclplines in de stage-opzet te warborgen.

De actlwitelten van deze planningsgroep vormen het onderwerp van de overlge paragrafen wan dit hoofdstuk. Allereerst wordt aandacht besteed aan de eerste hoofdtaak, het ultwerken van het stage-antwerp, daarna wordt aandacht bestead aan de werving an voorberelding van hul sarts-oplelders.

2.3.2. Concretisering van de stagedoelstellingen.

In de everste note over de stage-opzet (Broumer, 1977) wordt ean vlertal doel stell Ingen woor het PMOH onschreven:

1. het kennlsnemen van en Inzlcht $\mathrm{krljgen} 1 \mathrm{n}$ de achtergronden van de klachten, problemen en vragen, dle regellmatig aan hulsartsen worden voorgelegd, alsmede het leren kenmen en begrljpen van de presentatie van dile problemen;

2. het anleren van vaardigheld in het op de huisurtsaltuetie afgostende, methodlsch benaderen van dle klachten, problemen en wragen; dearblJ specla all andacht to besteden an de belangrlJkste aspecten van het hulpwerleningsproces in de hulsartspraktljk, namelljk dl- 
recte toegankell Jkheld, contlnulteit van de hulpver lening, hulpverlening in ocute sltuatles, preventleve hulpverlening, begeleiding van chronlsche stervende patlënten, de hulsarts-patlënt-relatle;

3. het aanleren van vardigheld in de varslaglogglng daarvan;

4. het verwerven wan de kennls en heit linzlcht, dle voor adequate hulpverlening verelst zlJn.

Naast deze doelstellingen worden ook en autal uitgangspunten geformulaerd:

1. de organlsotlie van hot Praktisch Medisch OnderwlJs dient to geschleden valgens grondslagen, de voor het gehelo Mastrichtse curriculum gelden. Dit betekent dat probleen-georlënteerde benaderlng, zel fwerkzamheld, formatlove evaluatle nast sumatleve evaluatle en attltude-antwikkeling ook in de vorngeving en in de praktijk van het PMOH herkenbar moeten zill

2. de structurerling van het PMOH wordt nlet gekenmerkt door afbakenling van een bepal de categorle aandoenlingen, maar door een speclale gerichtheld op de aard van het probleem-aanbod en op aspecten van het hull pver llen Ing sproces:

3. de facultelt dlent een tralningsprograma ter voorberelding van de hulsarts-oplelders to ontwerpen en ult to voeren;

4. bljzondere aandacht verdlent de aanslulting van het PHOH op de voor afgaando vier Jaren;

5. de student besteedt ongeveer de helft van zljn tljd aan activitelten in de hulsartspraktlJk; de andere helft is beschlkbaar voor zellstudie en activitelten aan de faculltelt;

6. voor het Praktisch Medlsch Onderwljs zlJn dr le maanden beschlkbaar.

Aan onderwilj skund Igen wordt vaak de taak toegekend an docenten die een bepaald onderwlJ sprogramme voorberelden to laten werken volgens een bepald model wan onderwijsontwikkeling. Fundamenteel wordt in die takkopvatting vooral gezlen het helpen formuleren van doelstelllingen an van daruit the komen tot spen spelflcatle van het onderwiJsprogramma. Hoewell de planning wan hat PMOH zeer goed te beschrljven valt volgens currlculumontwlkkel ingsmodellen, mag daarulit nlet geconcludeord worden dat sprake is gewerst van een strategle, dle bewust door een onder wIJ skund Ige ls Ingebracht.

Ean drletal factoren zijn in hoge mate verantwoordel lik voor het wellslagen van de voorberelldingstase:

1. het beschikken over en nota, war in met enthouslasme en stage-opzet geschllderd wordt an war lin met raal l sme gewezen wordt op knellpunten, dle in de voorberelling dienden to worden opgelast; 
2. de betrokkenheld van de leden van de planningsgroep blJ de opzet van $d i t$ onderwlj sexper lment;

3. de sprelding van deskund lgheden in de planningsgroep, wardoor ultoenlopende taken zoals werving van oplelders, structurering van leeractiviteiten, tralning van oplelders, ontwerpen van vers llegleggingsmodellen, etc., op adequate wijze konden worden ultgevoerd.

Op basls van de ultgangspunten on doelstellingen en een antal schetsnotilge suggestles voor de verdere concretliser Ing kon de planningsgroep an het werk. Centraal stond de vraag: op walke wljze kan de planningsgroep warborgen, dat studenten gedurande dr le maanden efflelënt en effectlef kunnen worken aan de doelstellingen van de stage. All snel werd het spannlngsveld zlchtbaar tussen het opdoen van rellevante ervaringen en het bereiken van meer theorstische doelstellilingen. De achtergrond hlervan was dat verondersteld werd, dat het opdoen wan relavante orvarlingen vooral door een nlet-sturende houding van de planningsgroep zou worden gestimuleerd, zodat student on oplelder op basls van een zell $f$ op te bouwen vertrouwensrelatle zouden kunnen ultmaken wat zinvolle en relevante ervaringen voor de student kunnen zlJn. Aan de andere kant leek het duidelijk dat het in de zo ontstane diversitelt van ervaringen erg moellijk zou zlln an to bevorderen dat een antal speclfieke doelstellingen (een Impliclet "kerncurrlcullun") berelkt zou worden.

Een tweetal factoren heeft ertoe bljgedragen dat een betrokkelijk gestructureerde aanpak door de planningsgroep gerd gozen.

1. Alle leden van de plannlingsgroep hadden ervarling in het plannen van anderwilsblokken In de eerste vier studlejaren. Dit stellde hen in staat de parallel te zlen tussen het speclfliceren van leeroporachten voor studenten in de varm van papleren-patlëntproblemen en het speciflceren van leerervarlingen dle en student in de praktljk zel* kian opdoen.

2. De onzakerheld dle men had ten aanzlen van datgene wat in de hulsartspraktljk mogelljk zou blljken, leldde ertoe dat sterke nadruk word gelegd op de rol dile de facultelt in de stage diende te spelen. Dit veronderstelt, dat men onschrly tt wat wel en wat nlet op de stageplaats dient to gebouren.

De belangrljkste aspecten van de stago-opzet zullen nu achtereenvolgens besproken worden. 
2.4. De onderwijsleersituatie.

2.4.1. Activitelten in de hulsartsprakijk.

Een van de ulitgangspunten van de stage is dat studenten ongever de helft van de beschikbare tijd doorbrengen in de hulsartspraktljk. Een antal overwegingen heeft geleld tot deze opzet.

De erste overwegling is van onderwijskundige aard. In de eerste vier jaren wan het currlcullum in Mastricht is de schelding tussen pre-klinische en kllnische vakken sterk vervaagd; studenten studeren vanaf het erste jaar an de hand wan problemen, die veelal ontleend zijn aan de gezondheldszorg. De keerzijde van deze opzet is, dat de latste twee studlejaren, dle elders vooral de functle vervullen van mtoepassen wan erder geleerde kennis" In Mastricht cok nog de functie vervullen van het aanleren van kennis, dle elders in de eerste vier studlejeren wordt verworven. Een parttlme-stage bledt de student mogell jkheden om zlch deze kennis elgen te maken aan de hand van concrete patlëntproblemen. Bovendien kan in een dergelljke opzet aandacht worden besteed aan facetten van de erstelljnsgezondheldszorg, die nlet direct patlëntgebonden zijun.

Een tweede overweging is van praktische aard. De structuur van de eerstellinsgezondheldszorg, waar in hulsartsen veelal als sollst werkzaam zil $n$, makt het onmogell ijk am de totale verantwoordelljkheld voor het studleproces van de student gedurende een paar maanden aan hulsarts-opleider over te dragen. De hulsarts-oplelder zal hlertoe in het overgrote deel van de gevallen te welnig tljd kunnen vrljmaken. Daarinast is het onmogel ljke opgave on praktljken te selecteren, waar in zinvol aan alle stagedoel einden gewerkt kan worden; een zekere taakverdel Img tussen stageplaats en facultelt bllijft noodzakellijk.

De nota Brouwer omschrljft een antal activitelten, dile studenten in de hulsartspraktljk kunnen ondernemen:

a. het bljwonen van het hulsartsspreakuur en het observeren van de hulsarts,

b. met spreekuurpatiönten an amnestisch gesprek woeren en deze fysisch-dlagnostisch onder zceken (15-20 per week),

c. patienten thuis bezoeken (enkele per weak),

d. maken van een probleemgeorlënteerd verslag van deze contacten,

๑. bespreken van de verslagen met de hulsarts-oplelder. 
In de ultwerking door de planningsgroep wordt de actleve rol van de student in de praktljk benadrukt. Howel obseirvatle van complex professloneel handelen belangrlJke leermomenten kan hebben (Vaogs 1975; Bouhuljs 1976), wordt deze act|vitelt blj de vormgeving nlet sterk benadrukt, andat het gevarar bestaat dat de student hierdoor in een passleve rol kan blijwen steken. Observatle ols activitelt wordt dan dok voornamellJk in de eerste weken van de stage als mogelljkheld naar voren gebracht en de nadruk wordt gelegd op het zo zelfstandig mogelljk werken met patiēnten. Het begrlp "zo zelfstandlig mogelljk" behoefdo daarbly geon nadere ultwarking. Een vijfdejarsstudent bezlt gean modische bewoegdheid en zlln functio in de hulsartspraktijk verschllt daarmee van de arts-assistent uit de beroepsopleliling tot hulsarts. Do latste is Imers bevoegd en kan zelfstandlg patlënten behandelen. De verantwoordell Ijkheld voor het behandelen van ean patient blljft in het erste geval echter geheel blj de hulsarts-oplelder llggen.

Het workmodel, dat an hulsarts-oplelders on studenten ulteindelljk wordt angeboden is als wolgt:

- de huisarts-oplelder selecteert en patlënt; ldeallter bepalt de hulsarts-oplelder na het aanhoren van de hulpwrag of de student met deze patlênt en gesprek kan hebben;

- de student voert het gesprek met de patlënt en onderzoekt deze zonodlg; de anwezigheld van de hulsarts-oplelder is hierbij nlet noodzakellJk;

- de student maakt een verslag van zljn bevindingen en zet voorstellen voor behandeling, theraple of verwljzing op papler;

- de hulsarts-oplelder rondt het consult met de patlënt af;

- het patlëntencontact wordt nabesproken op basis vam het verslag van de student.

De zelfstandigheld van de student komt dus tot ultdrukking in de gespreksvoering en het onderzook, mar zljn conclusles en voorstellan tot behandeling rlcht hll niet tot de patlënt. Het is dulldelljk dat In deze werkwijze de verslaglegging on de nobespreking, warop l] nog ultwoerlg zullen terugkomon, en cruclale rol in het leerproces spolen.

Het leak de plannlingsgroep om verschlllende redenen nuttig een rlchtHIIn te geven, met welke klachtengroepen de studenten gedurenide hun stage to maken dlenen te krljgen. Blj de selectle ls ultgegan van de indelling wan voor de hulsartspraktijk relevante klachtencategorleen, zoals die zilJn samengewat in "Het Kompas van de Hulsarts" CDuursma et all., 1973). De selectlie werd gemaakt door een vilftal hulsartsen, 
warblj de volgende or Iterla werden gehanteerd:

1. Hert elgen karakter van hulsartsgeneeskunde.

1) het problemanbod, dat gekenmerkt wordt door:

a. het vrlj grote antal kiachten van nlet-ernstige aard,

b. de velvuldige werwevenheld met milleufactoren,

c. de presentatle van de klacht, dle nog nlet beinylloed is door ultispraken van med lsche zljde.

2) De accentuering van bepalde especten van het hulpverleningsproces:

a. de verwevenheld van somatlische, psychlsche en matschappelijke factoren,

b. de Invioed wan interactles binnen het gezin op zlekte en zlektegedrag,

c. de contlinuitelt in de zorgverlening,

d. de potlënt-hulsarts-relatie als basis van hulpverlening en begellelding van de patlënt.

11. Onderwlj skund ige or I ter la.

1) De an de orde te stellien onderwerpen moeten in princlpe een breed scala van mogellijke dlagnoses bestrljken, waardoor hert mogellijk wordt dat de besllssingsmomenten in de werschlllende casus duldelljk an de orde komen.

2) Er $2 / \mathrm{Jn} k$ lachtengroepen die beter tIjdens de andere stages (k\|lnische stages, psychomedische stagel aan de orde gestell kunnen worden, doordat daar een concentratie van deze patlënten te vinden is.

3) De gekozen klachten, symptomen of problemen worden bij uitstek geschlkt bevonden als onderwerp voor Individuele actlvitelt en patiëntger lichte onderwijsgroepsblijeenkonsten gedurende het PMOH.

Dit resulteerde ultelndelljk in de lijst van klachtencategorleän, zoals wergegeven in tabel 2-3.

Nasst hat spreken met en onderzoeken van patlänten wordt van de student verwacht, dat hil cok op andere wijze kennls maakt met de taak en werkwiljze van de huisarts, bljwoorbeeld door het vervolgen van patiënten dle verwezen worden, door het partlclperen in overlegsituatles met andere warkers in de eerstelljusgezondheldszorg en door het particlperen In de warneming. 
Tabel 2-3: LiJst van aanbevolen klachtencategorleen wit het bllokboek PMOH 1978/79.

De patlent met hoofdplinn.

De patlënt dle hoest.

De patlënt dle het benauwd heeft.

De patlent die bloed opgeeft.

De patlënt met plJn op de borst.

De patlënt met pljn in schouder, arm on hand.

De patlënt met rug- of lendeklachten.

De patlënt met heup-, been- en voetklachten.

Het klnd met viekjes.

Levensbedrelgende acute toestanden.

De patlënt die overspannen is.

De patlēnt dle dulzellig is.

De patient met anormale hoge bloeddruk.

De patiēnt met acute hoge koorts.

De patlënt met magklachten.

Het $k 1$ nd met hoge koorts.

De patient die vermoeld is.

De patlënt met dorst.

De patiènt met anderbuikklachten.

De patlënt met obstlpatie.

De patlënt met seksuele problemen.

De patlënt met aedemen.

Het kind mot bulkplJn.

2.4.2. Vers lag logg Ing.

Het leren maken van een adequat verslag van hot student-patlënt-contact, vormt wan de doelstellingen van de stage. Het belang van on dergelljke doelstelling behoeft op zich weinlg toellchting in ean 1 ljd war In zeer veel publlcatles verschljnen waar In een goode verslaglegging als worwaarde voor het professioneel handelen en de contrôle daarop wordt beschouwd. Daarnaast bledt het maken van een verslag de student de gelegenheid an ziJn ongetwljfeld nog nlet voldoende gepoIIJ ste gedachten vast te leggen met het doel deze nader te exploreren 


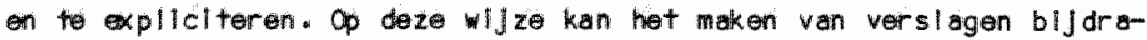
gen tot het ontwikglen van een neer method sche werkiljze.

Nast deze belangrlJke InhoudellJke argumenten om an de werslagleggling rulme andacht te schenken, beschouwde de planningsgroep de verslagleggling ook als het belangrlJkste comunlcatlemlddel, wardoor de student zlchtbar makt welke octlvitelten hIJ in de piraktljk ultvoort. Aangezian de student in de regel patlïnten onderzoekt bulten de a anwazlgheld van de hulsarts-oplelder, zall het verslag hat ultgangspunt denen tormen vaor ween kritlische nabesprekling, warin de student kan raflecteren en terugkoppel ling kan krljgen.

Directe speclfleke terugkoppeling is ben belangrlJke onderwllskundige voorwarde an het leren te bevorderen (Buls, 1978).

Regelmatige verslaglegging betekent $\infty$ k. dat de facultalre medewerker, dle verantwoordelljk is voor de begelelding van een groep studenten in de stage (hilerno to noemen de hulsarts-begelelder) "op afstand" gelinformeerd wordt ower de actlvitelten van de student. HIJ kan bljvoorbeeld nagaan of de student In de lloop van de stage een redelljke va$r$ lëtelt van $k l$ achten hest ontmoet.

Voorts werd verondersteld dat in groepsbljeenkomsten van studenten godurande de stage patlëntverslagen en ulltgangspunt voor de discussle zouden kunnen ziJn.

Veeil tijd on energle is ar gestopt in de ontwlkkelling van een verslagloggingsformuller. Ultgangspunt voor de plannlngsgroep was, dat zoveel mogel lJk angesloten diende to worden blJ het streven van de facultelt on de zogenaamde probleengeor lënteerde verslagleggling te hanteren. De omvangrljke formulleren, die voor het gebrulk in de klinlek in ontwlkkelling waren, leken slecht brulkbar als model voor de hulsartspraktljk. Vervalgens werden en antal modellen voor verslaglegging ult Grcot-Brittanle op tiun brulkbaarheld bekeken. No enlge proefversles, war In de verschll lende sectles wan de probleemgeorlënteerde verslagleggling waren voorgedrukt op het formuller, ward ulteindelljk gekozen voor formuller (Journal) dat betrekkelljk eenvoudlg van opzet is ( 2 le flguur 2-1).

Nazst de personal la van de patlënt, de naam van de student en de datum van hat contact is het rechterdeel van het formulliler bestemd voor de bewindingen ven de student. HIJ dlent dit in te vullen volgens de rlehtlijnen van de probleangeorlënteerde verslaglegglng. Het llinker deel is bestemd voor commentar van de hulsarts-oplelder. Onderaan links is en lljstje met onderwerpen, die in de ribesprekling a den orde kunnen komen, afgedirukt. De bedoeling is, dat de huisarts-oplel- 
Flguur 2-1: Model van ingevuld Journatl.

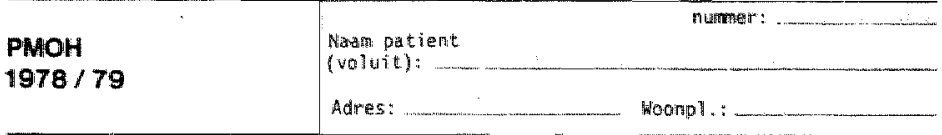

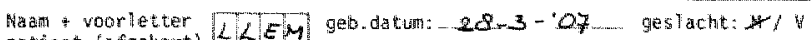

patilent (afgekort) $\angle L E M$

naxa梢 scudant:

consult /

datum kontak 13 sou

-) lethen aro padapes

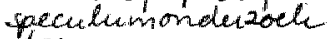
docin.

E) probapo proce katpetio pontie veladet

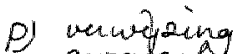

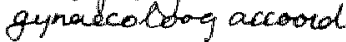

beldingrijikste onderwerpen in we nabesprekung:

\begin{tabular}{|c|c|}
\hline anchase & \\
\hline 1 ich. onderaok: & $v$ \\
\hline 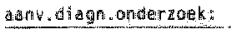 & \\
\hline houd ingrgedrag petient & \\
\hline houd ang/geding student & \\
\hline 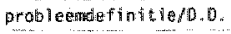 & 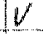 \\
\hline the pap iefrae of ot tie & \\
\hline vernijzing & \\
\hline 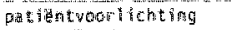 & \\
\hline
\end{tabular}

51 PIJM IT RUG EM OMDERBIJK, EERST ALLEEN STACHTS. NU OOK OUERDAG. SINDOS EEN WEEK DOK MIEREND CEWOEL. SOMS LAST UAM KOUDE VOETEN. NUMARR. ARTS, OMOAT KLACHTEN ZO LAMO AANHOWDEN. GEEN ALGEMENE KLACHTEM Mictie: G.S. ONTLASTING: S. konors $s$ GEEM PIIN MET HOESTEM, WIEZEN, PERSEN FANESTHESIEENO

O) STERKE LUMBALE LORDOSE EN CERUICOTHORACALE KYPHOSE

WRIJ STARRE RUO.

WERLELS NIET KOPPIJNCIJK.

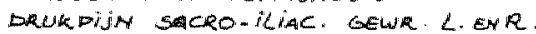
KERNIS: $\rightarrow$ Buik: "TORS ABDOMEM! AUSC. 7 . G.B. PALP: WEERTHANO LI. ONDER?

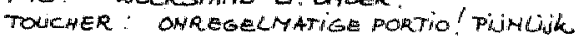
KON UANWIEGE GESPAMNEN DLPKSPIEREM LEEN OOED ONDERTOEK DOEM. BLOED AAN DE HANOSCHDEN! ExTREM: SENS. $2 G B$.

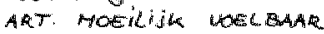
Houde WOeThW"

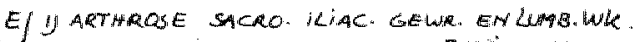
2) PATHOL intw Gasl ORA. - Poktio CA. EROSIE PORTIO myoor

Pf WERWIIZINE MAAR SYAMECOLOX

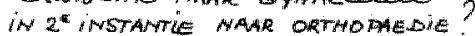

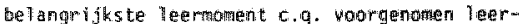

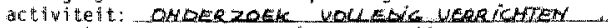

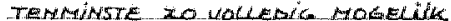


der ne loop van besprekling de belangrlJkste gesprekspunten aangeeft (In de Instruct le an de hulsarts-oplelder werd gezego niet meer dan tweo categor an an te strepen).

Rechts onderan hot Journaal kan de student aangeven, wat naar zlj.n mening de belangrlJkste leerpunten blj de behandelling van dit probleen zijn geweest. De planningsgroep chtte het van belang, dat verslagleggling en nabaspraking uitelndellJk zouden lelden tot en conclusie", dia rlchtling zou kunnen geven aan de zelfstudie van de student.

Gezlen het felt, dat het verslag zowel voor de student zelf, zijn hulsarts-opleider on de hulsarts-begelelder van belang is, werd gekozen voor een doordruksysteem, zodat leder verslag in dr levoud geproduceerd wordt. De nam van de patlënt drukt echter nlet door zodat alleen het orlgineel de nam van de patlënt bevat. Dlt orlgineel bllJft In praktillk. Het tweede exempllar is voor de hulsarts-begelelder en het derde exemplar bll Ift in het bezlt van de student.

Om het overzlcht over aantallen en soorten klachten te vergemakkelljken werd cok en weekoverzlchtsformuller ontwikkeld. Dit weekoverzlcht vervilt tevens de functle van Index voor de Journaels. Hlerdoor kan de student, dle in de loop van de stage meer dan honderd Journals maakt, snel lets terugzoeken (bIJwoorbeeld ten behoeve van vervolgconsulten, patlëntenbesprek ingen, etc.l.

Naast deze vorm van verslagleggling, dle gerlcht was op het samenvatten van gegevens uit spreakuurcontacten werd en omvangrljke status geintroduceerd ten behoeve van patiënten met een ulitgebrelide problematlek, bljvoorbeeld chronlsche patlënten, patlënten bl] wie veel a anvullende dlagnostiek nodig is, patiënten met een uitgebrelde medische voorgoschladenlls, patienten mat psycho-soclale problematlek, etc.. Voor de earste stagegroep werd hlervoor de Problem Orlented Medlcal Record, de woor de stage in de kllnle was ontwlkkeld, gebrulkt.

TiJdens de tweede stageperlode werd de 1 inmlddels verschenen NHG-gozinsstatus woor dit doel gebrulkt, aangezlen deze speclaal voor het gebrulk in de hullsartspraktljk is ontwlkkeld een kennlsmaking daarmeo door de planalingsgroep op prljs werd gestell. BInnen de planningsgroep bestond verschll van opvattling over de vraag in hoevorre het ma-

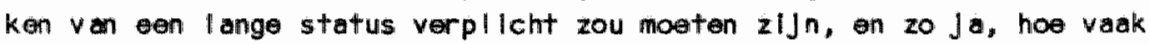
en student en dergelljke status zou dienen to maken. Uitoindelljk werd bisloten de studenten an te bevelon deze status enkello malen in to vullien gedurende de stage. 


\subsubsection{Onder ilj sgroepen.}

De nota Brouwer vaorzlet in wen willkse bljeenkomst, waaraan deelgenomen zou worden door acht studenten, hun hulsarts-begelelder on mogelljk andere facultalre medeworkers, dit tenelinde een mult|-dlsclp l|nalre bespreking mogel ljk to maken. Als centrate doelstelling van deze bileenkomsten wordt de toetsing van elgen ervarlingen au dlo van anderen gezlen. Onderwerpen voor de bljeenkomsten zljn ervarlingen, opgodaan met problemen, warblj de werwevenheld van somatische, psychlsche en maatschappellyke factoren groot Is. De vraag wordt opengellaten of de invulling van de bljeenkomsten door de studenten zelf, of door de pllanningsgroep dlent te worden verzorgd.

In de discussles binnen de planningsgraep werd vel aandacht geschonken aan de inwulling van de groepsbljeenkomsten an de rol van de hulsarts-begelelder in de groepen.

De functle, die an de onderwijsgroepen werd torgekend laat zlch als volgt omschrlJven:

1. de mogel ljkheld al ler lel ervarlingen ult de stagepraktljk met elkar en met de begellelder te bespreken ("spuien");

2. bevorderen van contact met de facultelt +ljdens de stage;

3. de mogelijkheld an patlëntenproblemen krltisch te bespreken aan de hand van verslagleggling;

4. de mogelljkheld am aandacht te schenken an themata, dle relevant zllin voor de erstellinsgezondheldszorg.

Hoewel er binnen de planningsgroep grote waarde gehecht werd aan het creeren $v$ an mogelljkheden on groepen aan spontaan opkomende zaken te laten werken, werd een structurering an verschllllende redenon noodzake IIJk goacht:

1. In on ongestructureerde opzet is de kans reäel dat studenten geen aandacht zullen besteden a aspecten van de gezondheldszorg, die nlet direct waarneembaar zl. In in het dagell IJkse contact met de patlênt.

2. Ervaringen in het voorafgaend onderwljs met ongestructureerde groepsbljeenkonsten wezen ult dat de zinvolheld daarvan nllet door alle studenten wordt onderschreven en dat drle maanden werken volgens een dergel IJke opzet vermoedel ijk nlet haalbaar is.

op grond van deze overweglingen besloot de planningsgroep dat de 
groepsbll onkomsten enlgszlns gestructureerd zouden worden: de helft van de bespreklngen wordt gereserverd voor het bespreken van patientemproblemen, de over lge bespreklngen aan thema's, die van belang zlln voor de erstellilingezondheldszorg (hlerop wordt nog nader teruggekomen). De llJst net patlentenproblemen en thema's dient zodanig te $z \mid d n$, dat gropen daarult en keuze kunnen haken. On cen rulm aantal kllachten en thema"s aan de orde te kunnen stellen werd besloten twee groepsiblj onkonsten per weok te orgamlseren.

De plenningsgroep besloot de hulsarts-begelelder als futor te laten functioneren van de studenten die hll begeleldt. Nast een procesbewakende en procesregulerende rol, kan hlj als "cllinicall futor" ge rlchte vragen stellen, problemen verhelderen, de discussle aanvullen on adviseren inzake situdleactlvitelten.

De anwezlgheld van inhoudsdeskundlgen, dle over bepaalde problenen geconsulteerd kunnen worden, vormde in de planningsigroep en punt van discussilo. Sommlgem bepleltten dat Inhoudsdeskundlgen ultgenodigd moesten worden wanneer bepaulde thema"s of problemen centraal stonden. Op deze manler zou het interdisclplinalr karakter van de stage worden gewaarborgd. Anderen hadden hlertegen bezwaren: de deskundlgen zouiden de groepsbll jeenkonst en enzljdlg karakter kunnen geven, wardoor andere belangrljke gezlchtspunten nlet naar voren zouden kamen; het op deze wiJze gebrulk maken van deskundigen zou te kostbaar zlljn en na verloop wan tijd toch moeten worden afgeschaft en tenslatte zou de vrlJheld van de onderwlJsgroep on haar werkw IJze te bepalen te sterk worden Ingekrompen. UlteindellJk werd besloten de groepen vrlj to laten in hun keuze an inhoudsdeskundigen ult te nodigen. Tevens kreeg de hulsarts-begellelder echter de taak te bevorderen, dat van deze moge$11 \mathrm{fkheld}$ ook deadwerkel IJk gebrulk werd gemakt.

\subsubsection{Blokbook.}

In en vroegtljdig stadlum van de planning werd het duldelljk dat de groelende strocm aanbevellingen, rlchtlljnen, regellingen, etc., op oen dullelljke manler aan de hullsarts-oplelders en de studenten gepresenteerd dlende to worden. In samenhang met het voorstel de Inhoud van de groepsbijeenkomsten voor structureren, besloot de planningsgroep in 
november 1977 een blokboek PMOH te produceren war in alle relevante Informat le zau kunnen worden opgenonen. In de ulteindellike vorm bevat het blokboek een overzleht van praktilsche zaken als groepsindelling, stageplaatsen, tljden van bljeenkonsten etc.. Voorts wordt ultvoerlg aandacht geschonken aan aspocten van de stage, zoals dle in dit hoofdstuk vermeld staan. Een belangrijk deel van het blokbook wordt tenslotte gewijd an diverse thema's met betrekking tot de enstelijnsgezondheldszorg, die door de plannlingsgroep na consultatle van alle capaciteltsgroepen zlJn vastgesteld. BIJ leder thema wordt aen korte inlelding gegeven on antal aanwilzingen hoe men indiwlduevl of in de onderwijsgroep aan thema zou kunnen werken. Een overzlcht van de thema's staat vermeld in tabel 2-4. Het opnemen van deze thema's reflectert met name de stagedoelstellingen, die nlet direct verbonden zijn met het contact met individuale patiönten.

Tabel 2-4: Thema's ult het bookboek PMOH 1978/1979.

1. Basisgegevens van de hulsartspraktijk.

2. Senenwerklingsvormen.

3. Hot verwiJzen.

4. Voorschrijf-en opvolggedrag.

5. Crisisinterventio.

6. De patiënt als gezinslld.

7. Het arts-patient-contact, gezien vanult het standpunt van patlëntenrecht.

8. De chem ische diagnostlek van de hulsarts.

9. RIs licogroepen.

10. Eval uatle van gegeven zorg.

11. De begellelding van stervenden on het rouwproces.

12. De begelelding van de chronlsche patlênt.

13. Je elgen perscon als hulpverlener.

14. De arts-patlënt-relatio als functionele samenwerk|ngsrelatie.

15. Arbeldsproblemen en de hulsarts.

16. Rel atleproblemat lek. 
2.4.5. De rol wan de hulsarts-opleider.

In loop van hat planningsproces kreag de rol van de huisarts-oplelder meer vorm en inhoud. De nota-Brouwer is over deze rol nog weinig explliclet. Geconstater d wordt dat de planningsgroep zlch eerst nauwgezet dlent te orläteren omtrent mogelljkkeden en beperkingen van de hulsartspraktljken, wat betreft praktlisch medisch onderwijs. Voorts wordt voorzlen, dat warschljnlljk sprake zou zljn van een ontwikkelling, wardoor zakem die in eerste anzet nlet ultvoerbaar zouden 2ljn, na enlige Jaren kunnen worden Ingevoerd. De "gastheer"m-rol van de oplelder mordt reeds duldelljk cmischreven in de nota: ledere oplelder krljgt gedurende een perlode van drle maanden éen student; hlj verleent de student gedurende deze +1jd toegang tot de praktijk en steltt de student in de gelegenheid het spreekuur blj te wonen, met spreakuurpationten een anamnestlsch gesprek te voeren en deze fys/sch-dlagnostlsch te onderzoeken en patiënten thuls te bezoeken. Er wordt echter gen duldel Ijke ultspraak gedaan over de vrabg of de huisarts-oplelder daarnaast de oerstaangewezene is om de student te stimuleren tot studie en zelf-reflectle.

Blj de concretisering van de stage-opzet werd duldelljk det het belangrljk is, dat de hulsarts-oplelder Inderdaad deze stimulerende rol vervult. De student onderzoekt Immers patlënten, dle cok door de hulsarts onderzocht worden en dle blj de hulserts bekend zijn. De hulsarts-opleider is dan cok meest angewezen flguur om de door Brouwer (1977) als basis voor het PMOH gekenschetsto vragen to stellen: Maaron heb je dit gevroagd, onderzocht on voorgesteld en nlet lets anders? Welke onderdelen van kennls, inzlcht, vaardigheden en attltuden zijn relevant voor dit probleom?".

De planningsgroep acht het dan cok essentleel, dat de oplellder in principe dagelljks met de student een nabespreking houdt op basis van de door student gemakte werslaglegging.

Deze worm van feedbeck wordt door de planningsgroep beschouwd als de belangrijkste vorm van Informele formatleve becordeling. Het regelmatige persoonlljk contact tussen hulsarts en student vormt bovendien een ultstekende basis voor een gesprek over kennen, kunnen en beleven van de student. Het belang hlervan wordt onderstreept door ervarlingen ol ders met co-assistentschappen (De Vries, 1979): studenten achten een gebrek aan persoonlijk contact met hun oplelder over hun orvaringen belangr ljke tekortkoming van co-assistentschappen.

Een discusslepunt voor de planningsgroep was, in hoeverre de huls- 
arts-oplelder cok betrokken diende te worden blj de formelle becordelling van de student. Zowel blinnen de planningsgroep als bimnen de kllankbordgroep waren er arzellingen op dit punt. Het belangrljkste bezwar was, dat de opleldingssituatle een zakere vertrowwensrelatle veronderstelt tussen oplelder en student en dat on beordelarsirol strljdlg kan zijn met dle relatle.

Aangezlen het voor de evaluatie van het PMaH-programma van vitaal belang was cordelen van de oplelders over de gang van zaken te reglstreren, werd uitelindel ljk besloten de oplelder wel an oordelen te vragen, maar daarblj duldelljk te stollen, dat dergelljke oordelen nlet verzameld worden on sen slaag/zak-bes/lssing to nemen.

2.4.6. De hulsarts-begellelder.

De hulsarts-begelelder wordt in de nota-Brouwer amschreven als de belangrijkste bewaker wan de doelstellingen wan de stage in de ultwoeringsfase. ZIJn functle kont glabaal overeen met de functle van de hulsarts-begelelder in de beroepsopleiding tot hulsarts, dat wll zeggen hij begeleldt zowal studenten als oplelders.

In het voorafgaende Is reeds een van de taken van de hulsarts-begelellder naar woren gekomen, namel IJk zijn functlo als tutor in de onderwljsgroep. Deze taak houdt mede in het voorberelden van bijeenkansten en het leggen van contacten met deskundlgen, dle een bljdrage aan de activitelten van de groep zouden kunnen leveren. Daarnaast achtte de pllanningsgroep cok de persoonlljke supervisle van ledere student door de hulsarts-begeleider van belang. Tljdens deze gesprekken met ledere student afzonder llJk kan op basls van de Ingeleverde verslagen negegaan worden of de student een voldoende gevarläerd aentall patienten heeft onderzocht, met welke aspecten hlJ problemen heeft, hoe hlJ zlJ $\mathrm{n}$ functioneren in de hullsartspraktll kk beleaft, etc. Verwacht werd dat de begelelder enmal per twee weken met ledere student en dergelljk gesprek zou voeren.

Voorts onderhoudt de hulsarts-begelelder cok contact met groep oplelders en met de oplelders afzonderlljk. Hlerop wardt in de paragraf over werwing en voorberelding van hulsarts-oplelders nog teruggekonen. Zonodig zou hlj ook beschlkbaar moeten zljn an patlënten-besprekingen over te nemen wan de opleider. Tljidens de stage zou er voorts regelmatlg over log tussen de begeleiders onderling on met on aantal mensem 
uit de planningsgroep dienen plat's te vinden an geslgnaleerde knelpunten op te lassen en In het algemeen "de vinger aan de pols te houden

2.5. Worving en voorberelding van hu lsarts-oplelders.

De tweede belangrljke taak voor de planningsgroep was, zoals reeds werd vermeld, de werving an voorberelding van hulsarts-oplelders. De nota-Brouwer besteedt ul ultwoerlg andacht aan deze taken. Ervar ingen aen andere facultelten wezen ult, dat het vinden van geschlkte hulsarts-oplelders vaak problematilsch is. Vandaar dat er reeds, voordat de planningsgroep formel met haar werkzamheden startte, contacten waren gelegd, dle leldden tot de vorming van de klankbordgroep, war in vertegenwoordlgers van de platsel ijke hulsartsenverenigingen zitting hadden.

De nota-Brouwer geeft an antal redenen aan waarom hulsartsen moge$11 \mathrm{Jk}$ terughoudend tegenover het oplelderschap $z / \mathrm{ln}$ :

1. De meeste hulsartsen ziJn onbekend met het Mastr lchtse onderwlJssysteem; men heft geen ldee wat studenten kennen en kunnen en er is onbekendheld met de student zelf. Welke Ideean houden zlJ erop ne?

2. Hulsartsen maken zich mogelljk zorgen over de reactle wan patiënten op de anwezlgheld van een student in de praktljk.

3. Hulsartsen vinden het wellicht ook zelf moeliljk afstand te doen van de beslotenheld van het arts-patlënt-contact door de aanwezlghelld van ean student.

4. Er Is onder hulsartsen wen vill veel voorkomend gevoel, dat men werkt op een nlveau, dat nlet in allo opzlchten voldoet aan te stellun normen. Dat gevoel ven "te kort schletten" kan betekenen dat men de student on de tacultalre medewerkers als een bedrelging ervart.

5. Hulsartsen hebben over het al gemeen geen onderwll servaring en een onderwlJsrol in deze experlmenterende opleldling is warschlJnllJk nog minder antrekkel lJk.

Gezien deze geslgnaleerde reservas en het feit dat het werkgobled van de capaclteltsgroep Hulsartsgeneeskunde in totaal slechts 300 huls- 
artsen omvatte diende de werving en voorberelding van hulsarts-oplelders uiterst zorgvuldig to worden ultgevoerd.

In nauw over leg tussen planningsgroep en klankbordgroep werd oen brlef opgesteld, warin informatle over het PMOH werd gegeven. Aan deze brlef was ultnodiging toegevoegd, an deel te nemen aan reglonale voorllichtingsbiljoenkonsten over het onderwils in Mastrlcht in het algeneen en het PMOH in het bljzonder. De brlef werd verstuird aen alle hulsartsen in het gabled van de PHV's Maastrlcht, Heerlen, S1ttard/Geleen en Roermond.

El nd november 1977 vonden de voorl lchtingsbljeenkomsten plaats in de vier voornoemder platsen. Tijdens deze avonden waren steods enkele loden van de plannlngsgroep, en vierdejarsstudent en een lld wan de klankbordgroep aanwezlg. Voorts was or informatlematerlaal over het onderwljs, waaronder ven videoband over de tralning In medische waerdigheden in Masstrlcht. Ruim 60 hulsartsen woonden de biljerikcomsten blj. Begin december 1977 werd ledere hulsarts, dle eerder belangstelIIng had getoond, persoonlljk benaderd met de vrasg of hiJ in princlpe bereld was gedurende dr le maanden een student in zlj. praktijk op te nemen. In total bleken ongever 40 hulsartsen hlertoe bereld. Deze waren werkzaem in 33 praktljken.

Wat betreft de aard van de praktijkvorm was de samenstelling van dle 33 praktijken als volgt:

$$
\begin{aligned}
& \text { totaal aantal } \\
& \text { praktijken }
\end{aligned}
$$

solo-praktijken

assoclatle-prakt ljken

groepsprak+1jken

gezond heldscentra

total

$\begin{array}{r}15 \\ 10 \\ 3 \\ 5 \\ \hline 33\end{array}$

aantel praktijken dat in 1978/79 twee maal "meedeed"

De sprelding over de reglo was als volgt:
Maastricht on onstreken
- 9 praktijken
Dostell Ijke Mijustreek
- 14 praktijken
Midden Limburg
- 10 praktjjken.

In de planningsgroep en In de klankbordgraep werd inmiddels gediscus- 
sleerd over de varg, welke crlferla an oplaldingspraktljk gesteld zouden moeten worden. Aangezlen or nog geen orvarling met een dergelljke stage was opgedaen on werving wan voldoende opleiders wal eens geen rullate voor selectle zou kunnen overlaten werd beslloten welillg stringente voorwarden to stellen en extra aandacht aan de begelelling van oplelders to besteden. Van oplelders wordt virwacht, dat ze enkelo jaren arvarlng als hulsarts hebben, beschikken over oen patlentenreglstratle an over woldoende rulmte on de student te laten werken. Dok dlenen oplelders bereld te zljn an voldoende tljd tor beschlkking to stellen. Tenslatte dienen oplelders berald te zljn deel te nemen an het woorbereldingsprogramo an aljeenkonstem tijdens de ultwoering van het stageprogramma.

Elnd februarl 1978 werd in Mastrlcht een bljeenkomst georganiseord voor de 40 asplrant-oplellders on meer gedetallleerd wensen mogellJkheden to bespreken. Over de stage-opzet kon op dat moment, dankzl」 de voortvarende planning van de opzet, meer gedetall leerde informatle worden gegeven. Naast overleg over zakell ljke punten als vergoedingen, contracten en ver zekerlingen, werd op deze blljeenkomst het plan geintroduceerd de hulsartsmoplelders aen twoedaagse cursus aan te bleden als woorberelding op hun onderwildsol. De bellangstelling hlerwoor was zeer groot.

Tussen maart en mel werden alle 40 praktljken bezocht door twee leden van de planningsgroep, tenelnde inzlcht te krljgen in de praktische mogell IJkheden en beperkingen. De gevoerde gesprekken boden tevens de gellegenheld nadere verduldelljking over de taak van de hulsarts-oplelder te geven. Ondertussen werd cok gewerkt aan de voorberellding van de tweedaagse cursus. De doelstellingen van deze cursus waren de hulsartsen vertrouwd to maken met hun onderwlJsrol, een aantal practlsche punten te bespreken en de band tussen oplellders en de facultelt te verstewlgen. BIJ de opzet van de cursus werd dankbaar gebrulk gemaakt van de ervarlingen die met name in Groot-Brlttanle met cursussen voor hulsarts-oplelders zljn opgedaan (Wrlght \& Knox, 1977; Rlchardson, 1976 ). Daarmast werd geprofllteerd van de ervar Ingen en Inzlchten, opgedian tljdens docentencursussen aan de facultellt der geneeskunde (Schinlat \& Bouhuljs, 1980).

Gezien de sterke reglonal sprelding van de asplrant-deel nemers an het belang dat gehecht werd a den de bevorderling van informele contacten, werd gekozen voor en anoengesioten cursus van twee dagen in oen conferentlecentrum, war de cursisten tevens overnachtten. De avonduren werden deels besteod an cursusactlvitelten, maar daarnaast was or ok gelegenheld voor informeel contact. Door deze gecomprimeerde opzet 
werd tevens voorkomen dat hulsartsen nlet zouden kunnen deelnemen wegens problemen met de warneming in hun praktlljk.

Voorafgaand an de cursus ontving ledere deelnemer het blokboak PMOH en een themanummer van Metamedilca, gowljd an het onderwljs in Maastrlicht. In de cursus zelf werd de functle van de nabespreklingen sterk benadrukt. Uitwoer lge aendacht werd ook geschonken aan de werslaglegging, de evaluatlle van de stage en aan practlsche zaken als de introductle van de student, het selecteren van geschlkte patiönten, welke verantwoordell Ikheden heeft de hulsarts-oplelder, wat doet de faculltit, etc.. Tussen augustus 1978 en Januarl 1979 werd de voorboreldingscursus drlembal georganliseard. op één hulsarts-oplelider na hebben al le oplelders van het stagej aar $1978 / 79$ de cursus gevolgd. Ult de schrlftelljke evaluatie van de cursus bleek, dat de opzet van deze cursus gewardeerd werd, met name de onderdellen waarblJ en actieve particlpatle van de deel inemers gevraagd werd.

Gezllen de behoefte van de planningsgroep on een goed Inzlcht te krlJgen in het functiloneren van de opleldingspraktllken en on de hulsartsen to stimuleren in hun nleuwe taak werd en intenslef contact met de oplelders gedurende de stage voorbereld.

Tljdens de eerste stageperlode werd na één, twe en drle maanden een bljeenkomst gepland tussen de hulsarts-begelelder en de 6-7 hulsartsoplleiders, dle tot de groep van de begellelder behoorden. Op deze blJcenkomsten weren ook de andragologe en onderwlJskundige aanwozlg. Als doeilstell'lngen voor deze bljeenkomsten werden gezlen, het ultwisselen van ervaringen, het kennIsnemen van bepaalde oplossingen wanneer zlch praktische problemen voordoen en het evalueren van de afgelopen periode. Voorts zouden de hulsarts-begelelders drlemal de praktijk bezoeken (na 2, 6 en 10 weken), tenelnde zich een Indruk te vormen van het functioneren wan oplelder en student.

Gezlen de aard on de onvang van de contacten tussen de facultelt en de hulsartsen in de reglo achtte de planningsgroep het gewenst dat ean faculltalre medewerker de functle van veldcoördlinator zou vervullien. Deze dient het overzicht to hebben over al lo deelnemende hulsartspraktijken zon zorg te dragen voor de continuttelt in del sumenwerkingsrelatle tussen hulsarts en facultelt. Deze continuttelt kan immers bly Wselling van begeleldersschap of een andere lindelling van onderwiJsgroepen nlet door de hulsarts-begelelder worden wargenomen. Voorts regelt de veldcoördlnator een aantal organlsator lsche aspecten van de stage zoals de lindeling van de studenten over de verschllilende stage- 
plautsen. Daernast werd cok inhoudelljke taak geformuleerd: de veldcoürdinator treedt bem Iddellend op, wanneer zlch problemen zouden voordoen In de relattie student-hul sarts-oplelder-hul sarts-begelelider. 
Hoofdstuk 3

Beoordeling en evaluatie

3.1. Inlelding.

Dit hoofdstuk heeft tweeledig doel, namel IJk hot beschrifven van procedures in het stage-ontwerp on de vorderingen van studenten te becordelen en het beschrljuen van de procedures, dle in dit onderzoek gebrulkt zijn om gegevens over het verloop wan de stage te verzamelen. Zoals reeds in het earste hoofdstuk werd ulteengezet ligt de nadruk in dit onderzook op het stage-ontwerp an op de wijze waarop dit ontwerp In de praktijk functioneert. De beschrijuing van beoordellingsprocedures als onderdeel van dat ontwerp ligt dan cok voor de hand. Met name staat hlarblf contraal de feedback-functie dle becordelingsgegevens kunnen vervullen voor de student, de hullsarts-oplelider en de plan$n 1$ gsgroep. Beoordel ingsgegevens zijn echter nlet alleen van belang on beeld to kunnen krijgen van de kwalitelt van het handelen van imdivlduen, ze kunnen ook informatile verschaffen over de kwalltelt van het onderwij sprogramma. Hofstee (1969) noent dit het 'averechts' gebrulk van becordellingsgegevens. In die zin maken de becordel ingsgegevens deel ult van de programa-evaluatle van de stage. Tevens wordt in dit hoofdstuk andacht geschonken aan de procedures on informatiebronnen, dle ontwlkkeld of gebrulkt ziJn om Inzlcht te verkrljgen In de gang van zoken tijdens de stage. De beschrljuing van de evaluatlemiddelen is in dit hoofdstuk beknopt gehouden. De meer speclfleke achtergronden worden bellcht in de navolgende hoofdstukken, zodat dle leder voor zich een $\mathrm{m}$ in of meer afgerond geheel vormen. 
3.2. Beoordelling van do worder Ingen van studenten.

3.2.1. De beoordellingsfllosofle van de facultelt.

Een bespreking van procedures, dle in de stage-opzet gebrullikt worden on de vorderlingen van studenten te beoordelan dlenen in relatio gezlen te worden met de beordel ingsopzet, zoals dle in 1978 door de facultelt as vastgesteld. Dle opzet fungeerde lmers als randvoorwarde woor beoordel Ingsprocedures in de stoge.

Sind 1977 worden de studleresultaten van studenten aun de facultellt der geneeskunde gemeten met behulp van zogenalande voortgengstoetsen, of zoals ze banvankell Jk cok werden genoend screenlngstoetsen. Deze toetsen, dle ontwlkkeld zijn naar een ldee van wijnen (1976), beogen regelmatlg vast te stellen hoever de student gevorderd is op weg naar het elnddoel, namel IJk hot basisartsniveau. De toets, dle vlermal per Jaar door all le studenten aan de facultelt wordt afgelegd, bestaat ult $\mathrm{J}$ / noe vragen over onderwerpen an wakgleden, dio rolevant geacht worden voor een bas/sarts. Uitvoerlge Informatle is te vinden in WiJnen (1977) en Imbos VerwlJnen (1982). De toetsen representeren dus nlet de Inhoud van het voorafgaande onderwils, maar vormen een operatlonal iserling van de elnddoelstellingen van de oplelling. Een bolangrlJk argument on een dergelljke vorm van toetsing te ontwikkelen was, dat op deze wijze de student een rulme mate van vrlifheld verkrljgt on op gelelde van in het onderwlJsprograma aangeboden problemen een elgen leerweg te klezen. De consequentio van deze keuze voor en programa-onathankelljke toetsvorm was, dat lle vormen van progromma-gebonden toetsing (met name de tootsen, dlle an het elnde van leder blok van zes weken worden afgenomen) ulltslultend een feedbackfunctle krogen voor studemten (formatleve beoordelling) on nlet meetelden blj hat nemon van beslisslingen over slagen of zakken van studenten.

De woortgangstoets werd beschouwd ols het eerste onderdeel van een ruimer pakket Instrumenten op het gebled van kennls, vaardlgheden en attituden (zle ontwlkkelingsplan Dealprojekt summatleve Evaluatle 1979). Op het ogenbllk, dat de erste stages in hat vlj fde en zesde studlej war werden ultgewerkt beschlkte de facultelt echter nog nlet ovar en ultgekrlstalll seerd plan an andere lementen dan kennls te meten. Aangezlen de facultelt op dat moment wenste vast te houden aan 
het Idee van programa-onathankelljke toetsing word door de facultelltsraad vastgestell, dat al le vormen van stagebeoordel lingen in het wijfide on zesde studlej ar eveneens ultslultend oen formatlef kerakter zouden hebben derhalve nlet zouden meetelllen blj hot nemen van slaag/zak besilissingen.

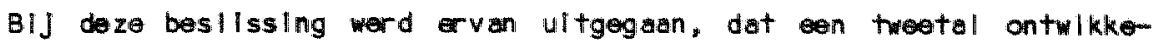
I ingen op betrekkel IJk korte term lJ n tot resultaten zou lellden, nemellJk het ldee on een gelntegreerd baslsartsexamen te ontwikkellen, warlin met name de $k \mid l n l s c h e$ competentle van studenten gemeten zou kumnen worden en het Idee on in samenhang met dit exemen oem zogenaamde efslultende perlode in het zesde studlejar op to nemen, warin de student in de gelegenheld is asngetoonde tekortkomingen in kennis en vaardighedien weg te werken. Op en antal voor- on in adelen van deze keuze zal nader worden Ingegaan in het hoofistuk over de verdere ontwkelling van de PMOH-stage (hoofdstuk 9).

Dit besllult betekende derhalve, dat kennlstoetsing in de stages geen invloed zou hebben op slaag/zak-besilissingen. Daarnaest hleld het beslult in, dat andere ellementen, zoals het functioneren van studenten in de praktljk en alle overlge actlvitelten dle gedurende de stege worden ondernomen op geen enkele wiJze van invloed zlJn op besillssingen van de facultelt over de studlevoortgang van studenten. In felte bestond er voor de student slechts de verplichtling on alanezig te zlJn op de stageplaats en deel to nemen aan bijeonkonsten dle In het kader van de stage werden georganlseerd. Het zal duldellik zlJn dat deze facultalre evaluatlefllosofle en belangrijke randwoorwarde vormde bij het ontwerpen van beoordellingsprocedures.

Aangezien de wlljze van becordelen van studleprestatles in de facultelt der geneeskunde in Maastrlcht nlet het onderwerp van deze dilssertatie vormt zullen or hler vanaf zlen deze keuze te onderbiouwen of te be$k r l+l$ serien. In hoofdstuk $9 z$ op deze problematlek worden teruggekomen in het kader van de verdere ontwlkkellingen rond deze stage.

\subsubsection{Stagebeoordel Ingen.}

Zoals in de worlge paragraat is uiteengezet zouden becordel ingen met betrekking tot de vorder Ingen van studenten in do stage geen Invloed hebben op beslissingen over de studlevoortgang van studenten (In de 
vorm van overdoen van een stage of zakkan voor ven axemenl. In dilo s.1tuatlle bllJven twe be lengrlJke functles van boordelingen over. De oerste unctle is het geven van Informatllo an de student over zijn vorder Ingen met hot doel zlJn gedrag to belnvloeden (feedback-functial. Dit wordt in de onderwijskund lge llteratuur aangeduld als format leve beoordel Ing.

De tweede functlle is het gebrulk valn beoordellingsgegevens woor het blJ stellem ven het onderill sprograma.

Het noemen van de functles, dle beoordeling kan hobben, vormt echter nog geen aandulding van de ard an i whoud van dle becordelling. Om dle vraeg to beantwoorden komen we terug op de algemene beschouwing over stages en leereffecten in hoofdstuk én en op de stege-opzot, zoal seschreven in hoofdstuk twee.

Het ontwerpen laten functioneren van en adequat terugkoppel Ingssysteen voor studenten gedurende en stage in de hulsartspraktijk is on twee redenen geen envoud lge zaak.

Het oerste probleam is het ultgangspunt, dat studenten zoveel mogel $1 \mathrm{Jk}$ zellfstandig patlënten Intervlewen on onderzoeken; dit betekent dat bll dit contact met de poflant in princlpe nlemand anders aanwezlg is. Het beoardelen van de kwalitelt van hot hendelen van een student kan in en dergelljke situatle nlet door directe observatle beoordeeld worden.

De tweede reden is dat en belangrlJk deel van de bedoelde leereffecten In een stoge zlch naw hun aard toch al nlet toegankel ijk maken voor objectleve meting, zoals reeds in paragraat 1.3.1. werd aangegeven.

Om In een dergelljke setting toch de kwalltelt van het handelen van en student te kunnen becordelen on blj te sturen is het van belang, dat ne af loop van het student-patlënt-contact oen zorgvuldige analyse van dat contact mogel ljk blifft. Vandaar dat de plannlingsgroep steeds grote nadruk heeft gelegd op twee essentlale voorwarden dearvoor, namellJk een beknopte vers laglegging door de student en nabespreking

\footnotetext{
* In het spraakgebrulk blinnen de RIJksuniversitelt LImburg wordt hiervoor de term "formatleve ov luatlen gebrulkt. De term mevaluatlon" wordt In de llteratuur westal gereserveerd voor de waardering van progrma's en onderdelen daarvan istenhouse, 1975; Stufflebean, 1972; Scriven, 1967). BIJ ultspraken over Indlviduen spreakt men bIJ woorkeur van "assessment".
} 
op basis van die verslaglegglng oor oplelder en student. In de voorberelding op de stage werden zowel studenten als oplelders arop gewezen dat verslagleggling en nabespreking de belangrljkste anknopingspunten voor formatleve becordeling en hot ondernemen wan zellstudie vormen.

Zoals ult de beschr lJving van de stage-opzet in hoofdstuk twee billkt ontrangt de hulsarts-begellelder eveneons aen cople van de verslagleggling door de student. Aangezlen de hulsurts-begolelder nilet aanivelg is in de praktljk en cok de patiönten nlet kent, kan hll in een beoordelende rol alleen afgaan op datgene, wat in het Journal vermeld wordt. In zlIn contacten me* de student, blnnen en bulten de onderWIJsroepsbljeenkansten, staen dan cok endere aspecten central, zoals de kwiltelt van de verslaglegglng, problemen die de student ondervindt in het contact met patiēnten, etc.. Deze vorm van begelelding van de student is cok in het stage-ontwerp opgencmen als ondersteunling van het terugkoppelingsproces van huisarts-oplelder naar student, De gedachte daarachter is, dat het proces van ferugkoppelling binnen de stagepraktllk bevorderd wordt, wanneor de hulsarts-begelelder toont, dat de facultelt de versleglegging eveneens serleus neemt. Men kan dit cok wat negatlever onschrlJven door deze aandacht te betttelen als vorm van contrôle of als "stok achter de deur".

Naast deze informele vormen van terugkoppeling aan de student over essentläle ospecten van zlln functloneren in de stoge, zlJn or aantal geformal lseerde procedures ontwlkkell.

op basis van de ingeleverde journaals wordt door de hulsarts-begelelder een overzlcht samengesteld van de typen patientenproblemen, dle de student In de praktljk ontmoet. Halverwege de stage wordt dit overzlcht an de student aangoboden, warblj opnerkingen over kwallitelt en kwantiteit gemakt kunnen worden. Hat overzlcht aan hat elnde van de stage kan de student informeren over de patlëntproblemen, die hil wel of nlet in de prakt IJk ontmoet heett.

In het stage-ontwerp is cok een aantal momenten voorzlen, warop de student gedetallleerde foedback kan krljgen over de kwalltelt van zlJn handelen.

Tweemal gedurende de stage (no de vlerde en de achtste woek) is cen beoordell Ingsmoment gepland, warblJ de hulsarts-oplelder een consult van de student blJwoont, beoordeelt aen de hand van eem vragenllyst en het resultat bespreekt.

Aan het ell van de stage doet de student een volledig consult met een 
simulatllepatlënt (een gezond lemand, dle on patlënt met bepalde $k l$ achten speelty. alt consult wordt op vldeoband opgenomen en door de hulsarts-begelefder beoordeeld aan de hand van een vragenllfst. Daarna volgt nabesprekling tussen student en hulsarts-begelelder.

Gegeven de evaluatlestrategle van de feculteit is aan de progranma-gebonden kennistoetsing weinlg andacht besteed. Tenelnde de studenten inzlcht te verschaffen in hun kennis ten aanzlen van de aanbevolen klachtenlifst (zle tabel 2-3) is tweemaal gedurende de stage een kennlstoets, bestaande uit $115 \mathrm{~J}$ a/mee vragen afgenomen. De erste toets halverwege de stage, de tweede toets an het elnde wan de stage. De toetsultslegen bevatten de score van de student, de genlddelde score van zljun mede-studenten on de gemlddelde score var oen groep hulsartsen in opleiding.

Voorts is de zogenaamde Rotterdanse hulsartstoets an het elnde van de stage afgenomen. Deze toets is ontwikkeld door de vakgroep OnderwIJsresearch en het Hulsartseninstifuut van de Erosmus Universitelt (Tober, van der Kllauw \& Groeneveld, 1977). Hoewel deze toets door de constructeurs ervan nlet wordt beschouwd als optimail toetsinstrument werd deze toets in het programal opgencmen, ondat scores van Rotterdanse basisartsen op deze toets bekend zlljn en zo zantrekkelljke mogel Ijkheld geboden wardt on aan het elnde van de stage oen vergel ljklng van kennIsnlveau ten anzlen van relevante terrelnen van de hulsartsgeneeskunde mogelljk te maken.

3.3. Evaluatie van de stage.

3.3.1. De functle van programa-eval uatle.

In hat eerste hoofdstuk is benadrukt, dat in dit onderzoek de constructle van oen stagepragrama centraal staut. In het twe hoofdstuk en in de voorafgaande paragrafen van hoofdstuk drle zlJh do hoofdlljnen van dlt programa besproken. Dan kant het moment, waarop het onder WlJsprograme ultgevoerd wordt en de vraag actueel wordt: werkt het programe ook? De onderwijskunde bledt aen veelheld van terminologle, benaderlingen en verflj $n$ ingen met betrekking tot de aanpak van evaluatle-vraegstukken. Een groot aantal daarvan is in publlcatle ven de stlehting voor onderzoek van het Onderwijs somengevat 
(SvO, 1980). Hofstee (1982) heoft getracht an to tonen, dat oen groot aantal terminologlsche onderscheldingen in benader Ingen in fellte 2 Inloos is. Het is in dit licht dan ook weinig armtrokkelluk allerlel modellien benader Ingen to bespreken.

Het verzamelen van informatle over de gang van zaken +lJdens de ultvoerling van het stageprograma diant an antal functles.

Allereerst is de programaverbeteringsfunctlo wan belang. Het stageprograma, zoals dat door de planningsgroep omschreven is, geeft geen volledige speciflcatle van alle activiteltien, dle lin drle maanden kunnem pleatsvinden: het fungeert als en model, dat nadere invullling dlent te krljgen in het felltelljk functloneren van het onder wiljsprograma. Het verzamelen van Informatle heeft voor de onderwljsconstructeur dan ook een functle in het beilnvlooden van de gang van zakem; zlJn eerste doel is nlet kljken of het model werkt, mar zorgen dat het programa werkt. Dat betekent, dat informatle gebrulkt wordt an de ultwoering van het programa te beinvloeden on blJ to sturen.

Deze functle is met name van belang voor oen stage-programa, dat gobrulk makt van cen zo govarleerde verzameling stageplaatsen, dle bovendien voor de eerste mal als zodanlg fungeren. BlJ de planning van het practisch medisch onderwijs in de hulsartspraktljk is or steeds vanult gegaan, dat tijdens de ultwoering op basls van beschlkbare informatle in over leg met studenten hulsarts-oplelders en nadere invulling en bllstelling van het stage-programe dlent plaats te vinden. De tweede functle van het verzamelen van Informatle is het kunnen boantwoorden van de vraog in hoeverre de stage-ultwoering aanslult blJ de doelstellingen van de stage. Het gaat hier an Informatle, die na afloop van het stageprograma gebrulkt kan worden om en oordeel to formulleren.

De consequenties van dot cordeel kunnen verschlllend zlly stellingen van de stage kunnen bljgesteld worden, nleuwe warkwilyen kunnen geintroducaerd worden, de wll ze van begelelding kan veranderd worden, men kan andere oplelders selecteren, nadere Ingangsel sen ste llen aum studenten, etc.. Het verzanelen van informatle past hler dus In een evaluatlecyclus, dile op langere term IJn tot consequentlos kan lelden. Eventuele veranderlingen kunnen betrekk Ing hebben op het stagomodel (en de doelstellingen) of op de IJ warop het programa wordt ult tgevoerd.

Twee typen Informatle zijn van belang an een programmo the kunnen evaI verien, namell Ijk informatle over de leerresultaten van studenten (pro- 
duct-oval uatloy en Informatle over de llye warop het onderwilsprograme gereallsear is (proces-ewaluatle). Blj de product-ovaluatle van oen stage-progr mama dient men nlet alleen te denken an resultatan op fudletoetsen, war ook adn zel f-oordelen wan studenten en door docenten gegeven becordel ingen.

In de proces-wallutie staan de onderwljsimspanningen en de onstandigheden waronder geleerd wordt centrall.

Aangezlen de relatle tussen leerresultaten en onderwljsinspaningen niet IInlallr wa zelfs onduidelluk is, Is het verzanelen van belde typen Informatle van belang.

3.3.2. Informatlebronmen tan behoeve van de programa-eval uatle.

In deze paragraaf zullen de verschlllende Informatlebronnen, die In het: verdere verslag van dit onderzoek een rol spellen, beknopt worden aangeduld. De meer speclfleke intormatie is to vinden in de hlerna valgende hoofistukken, waar In de resultaten worden ger apporteerd.

1. Een vragenlijst over aller lel facetten van de stage, wo door alle studenten aan het elnde van de stage werd Ingevuld. Deze programaevaluat levragen $1 / \mathrm{J}$ st bestaat ult 85 vragen, dle op on 5puntsschaal beantwoord kunnen worden en twee open vragen. Deze vragenllyst is in bljlloge 1 afgedrukt.

2. Een vardighedencheckllst, die door studenten aen hot begin, in het mldden an het elnd van de stage werd Ingevuld. Deze vragenllyst is bodoeld on lindruk te krljgen van het behoersingsnliveau van ren reeks vaurdigheden on na te gaan welke vaardlgheden tijdens de stage in de praktilk ziJn gebracht. De checkllst Is opgenamen in bly lage 2 .

In hoofdstuk 5 wordt nadere andacht an deze chockl Ist besteed.

3. De door de studenten ingeleverdo Journalis. in hoofdstuk 4 en 7 wordt hlerop Ingegaan.

4. Een tijdsbestedingsregistratle door mlddel van tlJdschr IJfformuller, warop wekell IJks door ean deell van de studenten hun tijdisbesteding werd genotoerd.

In hoofdstuk 4 word hler aan andacht besteod. 
5. Do Mastr lchtse Hul sartsenviragenllJst. Mat behulp van dit Instrument, dat aan het begin en aan het einde van de stage door studenten ward Ingevuld, wordt getracht inzlcht to krljgen in de attitude van studenten met betrekking tot voor de arts-patlënt-relatle relevante aspecten.

In hoofdstuk 6 worden de onder zoeksopzet on de resultaten besproken.

6. De in paragraaf 3.2.2. beschreven beoordelingen van de stulilevoortgang van studenten.

Deze komen aan de orde in hoofdstuk 5 en 8 .

7. De resultaten op de voortgangstoetsen (zle paragraaf 3.2.1.). Deze worden in hoofdstuk 9 gerapporteerd.

8. Een vragenlljst over allerlel facetten van de stege, welke door alle hulsarts-oplelders na 4 weken an het elnd van de stage werd Ingevuld. Deze vragenll] st bestat ult 14 vragen, dle op een 5-puntsschaal beantwoord kunnen worden en een tweetal open vragen. Deze vragenlijst is cok na 8 weken stage voorgelegd an de opleiders. Door wantal corzaken was de respons echter zo laag, dat de resultaten hlervan nlet gerapporteerd worden.

Aan het elinde van de stage is voorts een eanvullende vragenliJst met 12 vragen aan de hulsarts-oplelders voorgelegd. In de tabellen worden de vragen hlerult aangegeven met ean hoofdlletter.

9. Notul en wan planningsgroepvergader Ingen.

10. Verslagen van de hulsarts-begelelders over de gang van zaken in hun stagegroep.

11. Verslagen van de bljeenkonsten tljdens de stage van de hulisartsbegellelders met hulsarts-oplelders.

12. Informatie dle de onderzoeker verkreeg in gesprekken met studenten, oplelders, hulsarts-begelelders en ledien van de pllanningsgroep. 
3.3.3. Opian kIngen ovar de rapportige van de programa-evalluatle.

De hlervoor genoende Informatlebronnen zlJn gebrulkt on de wje warop stage godurende het studlejar 1978/79 voor do werste maal geroallswerd werd to owalveren. Gezlon de ard vam het onderzochte onderwlJsprograma on de aerd van de beoogde leereftecten is gekozen yoor en gevarleerd Instrumentarlum. Het is achter nlet mogelljk op grond vin deze bevindingen algemeen geldende conclusles te trekken over de kwalltelt van stages in de hulsartspraktijk. Daarvoor is de opzet van dit onder zoek nlet bedoeld en colk nilet geschlkt.

In de hoofdstukken $4 \mathrm{t} / \mathrm{m} 8$ worden de rasultaten ult het onder zook godurende het studlejar 1978/79 besproken.

In hoofdstuk 9 wordt op bas ls van het ulltgevoerde onderzoek aen beeld geschetst van de verdere ontwlkkeling van het PMoH in de studiejaren $1979 / 80,1980 / 81$ en 1981/82. Ter Illlustratle worden daarblJ cok routinemetlig verzamelde informatlo over het verloop tljdens die jeren gepresenteind.

De voortgangstoetsgegevens over deze studlejaren worden, blJ wiJze van ultzonder Ing op do Indel Ing van deze rapportage, in hoofdstuk 8 behandeld.

Gedurende het studlejaar 1978/79 volgden 45 studenten, al len behorend tot de eerste jarklas van de facultelt der geneeskunde deze stage. 24 studenten, verdeeld In 4 subgroepen, volgden deze stage van september tot en met november als eerste stage lim het vijfde studlejar. In de rapportage zal deze groep steeds als Groep 1 worden angeduld.

De overlge 21 studenten volgden, verdeeld lin 3 subgraepen, de stage van fabruarl tot en met aprll in hat vijtde studllejar, na reads an stage van zes maanden in het $z$ lekenhuls gelopen te hebben. Deze groep wordt verder wangeduld als groap 11.

Aan het elnde van het vierde studlejaar konden studenten hun voorkeur uitspreken voor cen bepalde stagevolgorde. Op 3 na wensten alle studenten to starten met het $\mathrm{POH}$. Deze voorkeur heeft warschlJnlljk mear te maken met hat blj studenten bekende felt, dat de facultelt grote holt had met het voorberelden van de zlekenhulsstages en de onstandigheld dat pas in een laat stadlum bekend werd, dat de zlekenhulsstages op 1 augustus zouden starten.

De ulteindelljk gevormde groepen bleken equlvalent te zijn op hun voortgangstoetsresultat an hat inde van het vlerde studlajar (zlo paragraaf 8.3.). Eventuele verschillien in resultatem kumnen dus nlet verkllard worden ult een verschlllende voorgeschledenls van belde groepen In de earste vier studlejaren. 
Hoofdstuk 4

Het verloop van de stage in het studiejaar 1978/79

4.1. Inleiding.

In dlt hoofdstuk wordt een beschrljuing gegeven van de gang van zaken tijdens de stage in de hulsartspraktljk gedurende het studle faar 1978-1979. BIJ deze beschrijuling is gobrulk gemaakt ven oental ter beschlkkling staande bronnen, zoals de programa-oval uatlevragenlijsten, de door de studenten ingeleverde journaals, notulen van bljeenkoristen van de planningsgroep en van bljeenkomsten met hulsarts-oplelders, het tljdsbestedingsonder zoek onder studenten verslagen van huisarts-begellelders over hun stagegroep. Een arste analyse van dit materlaal is oerder samengevat in een verslag van de planningsgroep over het studlej aar 1978/1979 (Planningsgrcep PMOH, 1979) en in oen artikel van Bouhuljs, Brouwer \& Mol (1979). De nadruk llgt In dit hoofdstuk op de onderwijsleersituatlo on op het cordeel van studenten en oplelders over de stage-opzet.

4.2. Activitelten van de student in de hulsartspraktijk.

4.2.1. Het ondervragen en onder zooken van patiênten.

Kernpunt in de stage is het praten met on onderzoeken van patiënten. Een analyse van de verslagen, dle door de studenten werden gemaakt van hun contacten met patiënten, geeft een eerste Inzlcht in de ondernomen activitelten. In flguur 4-1 ziJn allererst de total antallen verslagen vermeld, dle gemiddeld per student werden Ingeleverd. Ult deze getallen blijkt, dat in belde perloden het werwachte aantal van 15 verslagen per week (dus 180 verslagen per stage) nlet gehald werd. Do grote sprelding geeft bovendlen aan, dat or grote Individuele verschlllen tussen studenten optreden. 
Flgutr 4-1: Toteal antal 1 Jdens de stage geproducerde Journaals per student.

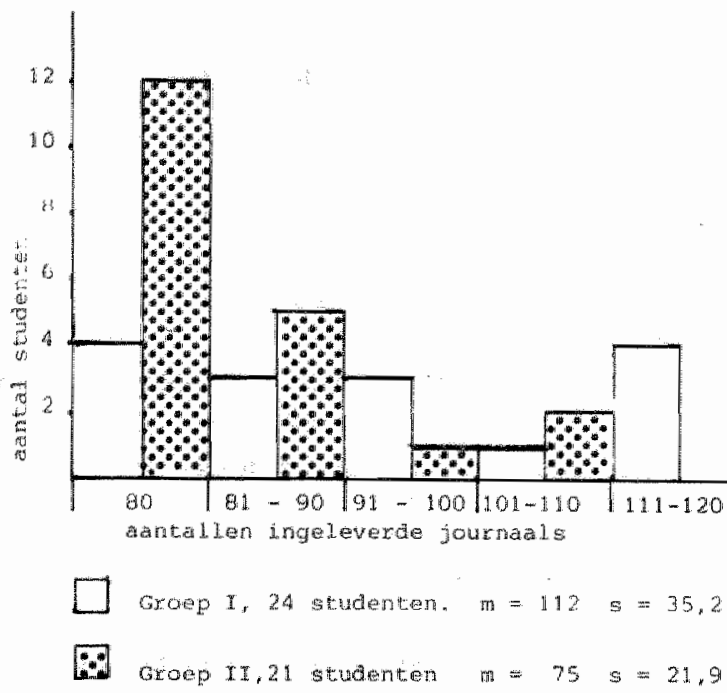

Bovendlen blljkt dat het antal ingeleverde journaals bil de tweede groep signiflcant lager is dian blj de groep (t-toets, tweezlJdige toetsing $p<0.001)$. Op deze meer speclfleke verschlllen zullen we nog nader ingaan. Aangezlien ult tabel 4-2 en ult gesprekken met hulsarts-oplelders blljkt, dat deze over het algemeen geen moelte hadden on een voldoende antal geschlkte patlënten to vinden, die door de student konden worden onderzocht, zljn kennelljk andere factoren verantwoordel l.jk voor hot lagere antal ingeleverde verslagen.

De eerste factor 1s, dat met name gedurende de eerste weken slechts en gering aantal Journaals werd ingeleverd. Dit zou erop kunnen $1 \mathrm{~J}-$ zen, dat studenten en oplelders en lge tijd nodig hebben om aan elkaar on aan het stagemodel tennen.

Een tweede factor vormen de andere activitelten, die studenten in de prak+IJk hebben ondernomen (hllerop komen wiJ nogi terug). Hlerdoor was or mInder tijd beschlkbaar voor "Journaal patlênten".

Een derde factor vormit de mate waor in studenten on opleiders het maken van verslagen zinwolle activitelt winden. Ult de antwoorden van de studenten op de vraag naar het nut wordt over het algemeen positlief geoordeeld (bijlage 1, vraag 28). Toch werd blj een aantal student-op- 
Ielder-teams een zekere onverschllligheld geconstateord, dle resulHeerde In en gerling antal ingelevorde verslagen. en ioruclas punt hlerbill IJjkt te zljn, de mato warlin de verslagen ultgangspunt vorm den woor de nabespreking. De meeste studenten geven aan dat de verslogen en inuttige rol vervulden blj dle nabesprekingen $(b i j l$ age 1 , vraag 24), maar dit is niet blj al le het geval.

Een laatste factor wormt de mate waar in de hulsarts-begelelders hun studenten stimuleerden tot het maken van verslagen.

Het verschil in aantallien Ingeleverde journaals tussen de belide stoge groepen is voor en gering deel toe te schrlJwen aan het gegeven, dit de tweede stagegroep ean antal dagen minder in de hulsartspraktijk is geweest vanwege de carnaval sperlade. Belangrlljker is echter de verschll lende voorgeschledenls van de tweede staglegroep. De studenten ult deze groep hadden needs stage van zes maanden in het zlekenhuls achter de rug. Over de organlsatle en gang van zaken tljdens die stage was men over het algemeen welnig te spreken. Vanaf de start van hun stage In de hulsartspraktljk bleek, dat men minder bereld bloek het ultgezette stageprograma te accepteren. Uit de antwoorden op de vragen, die betrekking hebben op de verslagleggling (bijlage 1, vraag 24 $t / m$ 28) bl lJkt dat de tweede stagegroep minder positlef oordeelde over het nut en de brulkbaarheld van de verslaglegging.

Dok ult en antal andere gegevens kan worden afgeleld, dat de verslaglegging in het oerste stagejar nlet maxlmaul benut is als middel on de leerervarlingen van studenten te sturen. Zo bl lJkt, dat studenten vaak nlet aangeven, wat ze als leermament of woorgenomen leeractivitelt beschouwen naar anlelding van het contect met de patient. BIJ een steekproef van 108 van de Ingeleverde verslagen ( $n=413$ ) blijkt dat blj 32 van verslagen een leermoment of voorgenomen leeractivitelt is vermeld. BIJ een even groot aantal verslagen is nagegaan of de hulsarts-oplelder opmerklngen in de marge van het versilag heeft aangebracht. Dit blijkt blj 62\% van de verslagen het geval to zljn.

Hoewel utt het nlet Invullen geen definltieve conclusles kunnen worden getrokken over het functloneren van de verslagleggling kan men $z$ lch wel af vragen, of de dagelljkse nabesprekingen tussen student on oplelder Inderdaad systematisch aen de hand van de werslaglegging hebben platsgewonden. In en antal govallen kan ult gesprekken met oplelders worden afgeleld, dat men meer informeel en tussen het werk door met de student sprak. Tiljdsdruk werd hlerblj wel als argument genoemd. Wanneer de verslaglegging een diracte Indlicator zou zlJn ven de mate van activiteit, die de student ontploolt in de hulsartspraktijk, den 
2ou de tweede stagegroep anzlenlllik minder contecten met patiénten gehad hebben den de erste. Ult gesprekken met oplelders en studenten Is echter duldelljk geworden, dat nlet alle student-patlantcontacten in een verslag zlJu cargezet. Met neme blJ de twoede stagegroep ontstond de gewoonte an allew verslagen in to leveren over contacten met petizanten, die klachten had, dle de student nog nlet was tegengekomen gedurende de stage.

De Ingeleverde verslagen bleden een good aanknoplngspunt om na te gaan met welke $k$ lachtien studenten +1 Jdens hun stage werden geconfronterd. Aangezlen de anbevolen. IIJst met klachten (zle tabel 2-3) ontleend was wan de Indelling volgens "Het Kompas woor de Hulsarts" (Duursma et al. 1974), werden alle blinenkomende verslagen gecodeerd volgens de daa gegeven Indelling, met toevoeging van een "restcategorle". Indlen de Inhoud wan het verslag daartoe abinlelding gaf, werden meerdere codes taegekend. De coderlng geschleddo door de hulsarts-begelelders, dle op ze wijze en overzlcht hlelden van de klachten, warmes studenten tljdens de stage in aanraking kwamen.

In tabel 4-1 zijn de twintig meest frequent voorkamende klachten ult belde stageperloden vermeld. BIJ ledere categorle is per student het gemlldielde antal journats wergegeven. De hiler vermelde klachten makkten in totail angeveer $80 \%$ van de geregistreerde klachten ult. Uit de gegevens blljkt dat studenten met name in contact komen met patlënten met stoornissen van het boweglingsapparaat, problemen rond het ademhallingsstel sel, maag- en bulkklachten, hoofdpljn en huldafwljklngen. BlJ de twintig meest frequent voorkomende klachtengroepen is nagegaan In hoeverre de frequentlevolgorde in de belde stagegraepen met elkar overeenstemen. De spearman-rangcorrelatle blljkt .72 te zlj $\mathrm{n}$. hetgeen angeeft dat de belde frequentlevolgorden sterk met olkaar overeen komen (p<.001); blj de tweede groep komen Juuk en nervositelt als klacht relatlef minder voor anti-conceptle en cogaandoen Ingen rollatiof moer.

In poragraat 2.4.1. werd $\| \mathrm{Jst}$ met $23 \mathrm{klachten}$ genoemd, dlo studenten als aanbevelling aan het bogln van hun stage meekregen. Twaalf wan dar gonoemde klachten komen woor op de llijst van twintig meest frequente klachten (alingegeven met een sterretje). Niet in dle list voorkcmende klachtengroepen, dle in de verslegen duldelljkk vertegenwoordlgd waren lagen mot name op het gobled van de dermatologle, K.N.O.-problemen, cogaandoenIngen on anti-conceptlo. Opval londe afwezlge klachtengroepen zlJn met name problemen met kinderen en alllerlel ecute problemen (levensbedrolgende problemen, acuut hoge koorts, bloed opgevenl. 
Op basll van de discrepentles tussen de abibevolen de gereglistreerde klachton kan men zlch afvragen In hoeverre studenten zllch hebben laten lelden door de lijst met anbevolen klachten. Ult de antwoordem op deze vraag in de programa-ovaluatle blljkt dat dit welnig of nlet het goval is. ( $z$ le bijlage $\|$, vraig 44 ).

Tabel 4-1: Twintlg meest frequent voorkomende klachtengroepen in de Journals tijdens het studle Jaar $1978 / 79$.

Gemiddeld aantal Journals per student
totale klachtencategorle
rang.

\begin{tabular}{|c|c|c|c|}
\hline $1 *$ & hoesten, verkoudheld & 13.8 & 13.3 \\
\hline $2^{*}$ & heup, been, voetk lachten & 12.0 & 6.1 \\
\hline $3 *$ & rugk lachton & 9.9 & 6.6 \\
\hline $4 *$ & schouder, arm, handk lachten & 10.0 & 6.3 \\
\hline 5* & hoo fdplj $n$ & 8.6 & 4.6 \\
\hline 6 & huldprob lemen & 7.7 & 4.9 \\
\hline $7^{*}$ & plJn op de borst & 5.1 & $3 \cdot 8$ \\
\hline$B$ & keolpljn & 5.6 & 3.0 \\
\hline $9^{*}$ & ben aum of held & 4.5 & 2.1 \\
\hline $10^{*}$ & onderbulkskl achten & 4.1 & $2 \cdot 3$ \\
\hline 11 & bovenbul ksk lachten & 3.4 & 3.6 \\
\hline 12 & Jeuk & 3.4 & $1 \cdot 7$ \\
\hline $13 *$ & vermoel dheld & $3 \cdot 3$ & 1.9 \\
\hline 14 & nervositelt & 3.3 & 1.4 \\
\hline $15^{*}$ & magk lachton & 3.1 & 1.6 \\
\hline $16^{*}$ & dulzellgheld & 2.8 & 1.7 \\
\hline 17 & oorpljn & 2.5 & $1 \cdot B$ \\
\hline 18 & antl-concept le etc. & 2.5 & 3.0 \\
\hline $19 *$ & abnormal bloeddruk & 2.5 & $2 \cdot 2$ \\
\hline 20 & oogaandoen IIng & 2.4 & 2.5 \\
\hline
\end{tabular}

* Klachten dle voorkomen in de senbevolen klachtenlijst, tabel 2-3. 
Het nlet goed functloneren wan de IIJst met asubevolen klachten bllJkt ook ult de antwoorden, dle studenten geven op de vragen in de programma-valuatle in hoeverre ze tljdens de stage in de vorm van studle, gesprekken, onderwlJsgroep, contact met de hulsarts-oplelder, inhoudsdeskundige, etc. aandacht aan van de aenbevolen klachten hebiben geschonken (bljlage 1, vraag $46 \mathrm{t} / \mathrm{m} 68 \mathrm{l}$. Studenten geven aan, dat ze welnig of geen aandacht besteden aan klachten, dle ze in de hulsartspraktljk winlg of nlet zijn tegengekomen.

De dlscrepantle tussen de aranbvolen klachtenlljst en de klachten, die voorkanen op de Journalls kan veroorzakt zlJn door verschlllende factoren.

Het is mogel IJk, dat en antal klachten nlet frequent op het spreekuur gepresenteerd worden, maar gezlen hun aard lelden tot een vislte, dle zlch afspeelt op HIJdstippen, dat de student nlet aanwezig is (b.v. acute hoge koorts). Ongetwljfeld speelt ook de selectle, dle de huisarts-oplelder makt, en rol. Uit gesprekken met oplelders blijkt ook, dat men vaak na verloop van tljd een werkwljze klest, dle weinlg rekening houdt met en aanbevolen klachtenlijst. Zo krljgen veel studenten in de loop van hun stage patlënten, dle tevoren nog nlet door de hullsarts gezien zljn. Van selectle vooraf op bepaalde klachten is dan geen sprake. Overigens slult deze werkwljze nlet ult, dat de hulsarts-opleider op basls van zlJn bekendheld met zlJn patlenten bepaalde patlënten gemakkell ljker aan de student overlat dan andere.

De ervar Ingen ult het eerste stagej ar hebben geleerd, dat het hanteren van deze $1 \mathrm{JJ}$ st $k$ lachten als sturingsmechanlsme nlet goed werkt. Anderzljds kan op basis van de orvaringen die feltelljk door studenten zlJin opgedaan een nleuwe lijst met klachtengroepen worden samengesteld; dle lijst bestat dan ult klachtengroepen waarvan men kan verwachten dat studenten dle in hun stage ook daadwerkelljk tegen zullen komen.

Ook kan geconstateerd worden, dat studenten in de loop van hun stage een gevarleerd klachtenambod tegenkomen. HlierblJ kan nog apgemerkt worden, dat ult informatle wan studenten en oplelders bliJkt, dat patlënten over het algemeen zeer bereld blljken zlch door een student te laten ondervragen en onderzoeken. Sommige hulsarts-oplelders hadden hierover voorafgand an de stage duldelljke twiffels.

In tabel 4-2 zijn de oordelen van de hulsarts-oplelders omtrent dit punt weergegeven. Howel de cordelen van patlënten hlermee niet direct worden weergegeven, kan men deze gegevens, gezien het belang van de oplelders bll een goede gang van zaken, wel als een indlcatio gebrulken. 
Tabel 4-2: Oordelen van de hulsarts-oplelders met betrekking tot het ondervragen on onderzoeken van potlenten door studenten.

Groep 1 Groep $\|$

$\begin{array}{llll}\text { na } 4 & \text { elnd na } 4 & \text { elnd } \\ \text { weken stage weken stage }\end{array}$

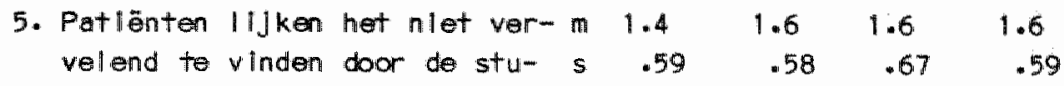

dent onderwraagd to worden.

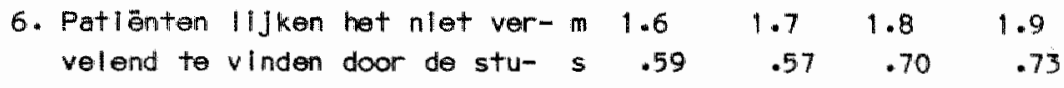

dent onderzocht te worden.

F. Het vinden van 3 Journaal- m - $3.8-3.9$

patlënten per dag vond lk s - 1.13 - 1.35 moell Ijk halbaar.

(antworden op en 5-puntsschaal: $1=$ volledlg eens, $5=$ volledig oneens..)

De resultaten geven aen, dat de oplelders de student nlet als en overlast voor de patlënt beschouwen. Somlige opllelders rapporteren, dat hun patlënten Julst het contect met de student op prijs stellen, omdlat deze meer tljd neemt om hun klachten aan te horen.

Zoals in hoofdstuk 2 werd angiegeven spelen de Journabls een belangrljke rol in de nabesprekingen met de hulsarts-oplelder.

In tabel 4-3 zijn de oordelen van de hulsarts-oplelders over de verslaglegging en de wije warop deze functioneert samengevat.

Uit deze resultaten zou men kunnen concluderen, dat het cordeel over de verslaglegging on de wJze warop die functloneert in de nabesprekIng over het algemeen pasitief is. Blj de resultaten kunnen echter kanttekeningen geplatst worden. Sommlge hulsarts-begelelders rapporteren, dat 21$]$ de Indruk hadden, dat cen aantal studenten hun verslag pas makten, nadet de hulsarts-oplelder het consult met de patlent had af gerond. 
Tabel 4-3: Oordelen wan de hulsarts-oplelders met betrekk ing tot de vers laglegging an de nabesprekingen.

Groep I Groep II
na weken elnd stage

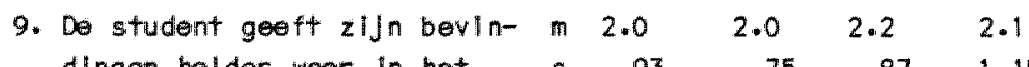

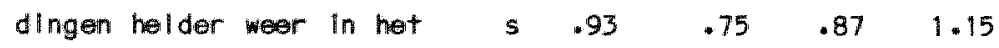
vers $\log$.

10. De student is in staat een
helder behandel ingsplan te schrljwen.

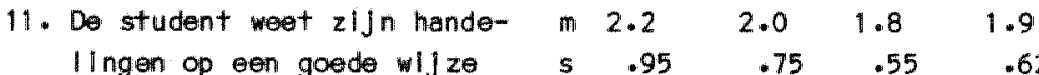

in de nabespreking te beargumenteiren.

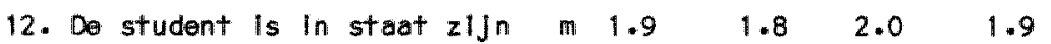
$\begin{array}{llllll}\text { tekorten in kennis en var- } & s & .66 & .78 & .86 & .85\end{array}$ digheden formuleren.

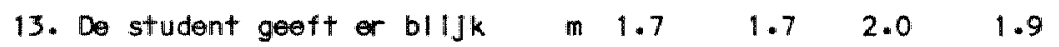
$\begin{array}{llllll}\text { van mijn suggestles t.a.k. } & \text { s } & .82 & .76 & .76 & 1.01\end{array}$ ges I gineleerde takorten na to komen.

(antwoorden op en 5-puntsschael: $1=$ vollledlg eens, $5=$ vollledig oneons).

Voor ean deel is dit cen gevolg van het felt, dat in een aantal praktijken de student Journalpatlëntem onderzocht, dle reeds en consult mat de hulsarts hebben gehad. Ult de antwoorden van studenten op vrasg 23, bljlage I kan worden afgeleld, dat dit Inderdaad in een aantal praktijken woorkwam. Uit de in tabel 4-4 gegeven antwoorden bllJkt, dat oplelders kennelljk vaker dan studenten dit verschiJnsel warnemen. Dit komt, ondat sommlge studenten met het maken van een verslag 
wachtten, totdat de hullsarts-opiellder (In hun bly $\mathbb{I} J \mathrm{n}$ ) het consult met de patient afgerond had. Dit zou Impliceren, dat het verslag nlet noodzakell Jk gebaseerd is $\infty$ wat de student zelf heeft vastgestell. op de kwall itelt van de verslaglegging zal in hoofostuk 7 nog nader worden ingegaan.

Tabel 4-4: Dordelen van de hulsarts-oplelders over het tljdstlp van versillaglegg Ing.

Groep 1 Groop $\|$

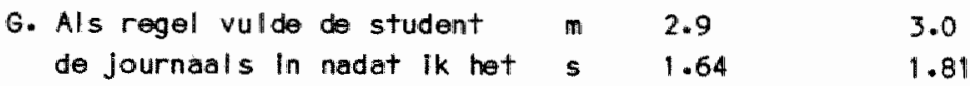

consult had afgerond.

H. Als regel had de student m $3.4 \quad 3.2$

de journaals ingevulld voor- $s \quad 1.67 \quad 1.75$

dat ik het consult had afge-

rond.

(antwoorden op een 5-puntsschaal: $1=$ volledig eens, $5=$ volledilg oneens).

4.2.2. Over lge activitelten in de praktijk.

Nast het zel fstandlg spreken met en onderzooken van patlënten +IJdens het spreekuur, worden de studenten door hun opleiders in de gelegenheild gesteld cok op andere w IJe kennls te maken met de hulsartsprak+lJk. Uit gesprekken met oplelders en studenten blljkt, dat in veel praktijken student en oplelder regelmatig samen en deel wan het spreokuur doen en samen wisites maken. In sommige praktljken maakt de student ook zelfstandlg visites.

Een aantal activitelten wordt meer incldenteel vermeld, zoals het bljwonen van een zuigellingenspreekuur, het meegaan met een verkeersslachtoffer dile per ambulance naar het zllekenhuls wordt verwoerd, het meegaan met patlënten naar de poliklinlek van zlekenhuls, het be- 
zceken wan pattürten in thet zlekemhuls, het onderhouden van contacten met andere erstellJ nsgezondheldszorgwerkers en het particlperen in de weekend- of avonddlenst. Dergel ijke actlvitelten worden door de eraan deell nemende studenten zonder ultzonderl ng gewardeerd.

4.3. De onderwlJ sgroepen het contact met de hullsarts-begeleider.

Zoals in hootdstuk 2 reods is wermeld, winden er twoemaal per week groepsoll Jeenkomstem plats van 6 of 7 studenten met hun hulsarts-begelelder. In de planning werden twee typen bijeenkomsten onderschelden, nemel ljk patlëntbesprekingen, warblj de orvaringen wan studenten met bepaal de kllachtencategor loen centraal staan en themablj eenkomsten, dle gerlicht zljin op meer algemene aspecten, die van belang ziJn in de hulsartspraktijk.

De deolname an de groepsbijeenkomsten was over het al gemeen bevredigend. Verzulm werd hoofdzakelljk weroorzakt door zlekte. Daarnaast bleken enkele studenten frequent nlet aanwezlg.

De rol van de hulsarts-begellelder ten opzlichte van de groep stuidenten, dle hlj ander zlyn hoede had, heaft zlch in de loop van het corste stagejaar verder ulttgekr I stall lizeerd. In de onderwlj sgroepsb ljeenkomsten neemt hlJ een andere posltle in, dan de tutor in de groepsbijeenkonsten gedurende de eerste vler studlejaren. De hulsarts-begelelder is namelljk nlet alleen tijdens de groepsbljeenkomsten, mar vooral cok daarbulten, sterk betrokken bl] het leerproces van de studenten ult ziJn groep.

Uit de verslagen, dle door de hulsarts-begelelder zljn gemaakt van hun werkzamheden, blljkt det studenten met name aanvankel ljk noelte hadden om zlch an to passen aan een sltwatle, warln de hulsarts-begelelder mear verantwoordellJkheden heoft dan futor.

Uit de verslagem van de hulsarts-begelelders en ult de antwoorden van studenten op de programa-evaluatlevragen (bljlage 1, vraag 30 ) kan woriden opgemeakt dat de bljeenlkomsten dle werden bestred aan patlëntproblemen over het geheal genomen woldeden. Ultgangspunt voor de besprekingen vormen meestal de Journaals, die door de studenten gepresenteerd worden. Deze werkwlJze bledt cok de mogell IJkeld on ervar Ingen, die studenten in de praktijk hebben opgedar te bespreken.

In stage-opzet was voorzlen, dat blJ deze bespirekllngen ook vertegenwoordlgers van endere disclp/lnes als inhoudsdeskundigen aenwezlg 
zouden kunnen zljw. Zowel blj de studenten als bij de hulsarts-bogolelders bleek echter cen duldell ljke voorkeur on onder lling deze besprekingen to voeren.

Het ver loop van de themabljeenkonsten was duldel ljk moelzamer. Uit de programa-evaluatie blijkt dat de eerste stagegraep daze bljoenkonsten minder aprecleerde dan de patientenbesprekingen lblJ lage 1, vraag 30 en 31). De studenten bleken er duldelijk moelto mee to hebben on zlch bezlg the hiden met thema's, dle niet concreet gekoppeld waren aan de problematlek van een bepalde patlënt. On de woorden van een hulsarts-begelelder te cilteren: "De discussle kwam dan ook meestal moelIIJk op gang en vertoonde weinig dlepgang. Ik heb mlj blj dle gelegenheden vaak een koploper gevoeld dle oen traag peloton tracht op gang te krljgen".

De tweede stagegroep wardeerde belde typen bljeenkomsten gell.jkel IJk. Hierult mag men echter nlet afleiden, dat de thema's ult het blokboek beter aan de orde zijn gekomen. De verslagen van de hulsarts-begelelders geven aan, dat in deze perlode door de studenten zelf, in over leg met hun begelelders, cen aantal nleuwe onderwerpen is gekozen, dle veelal medlsch-somatlisch gekleurd waren (bljyoorbeeld antllblotlca, receptuur, or thopaedlel. Het is duldellJk, dat hlerdoor het onderscheld tussen de patlëntbesprekingen en de themabesprekingen vervaagd Is. TlJdens de themamlddagen waren vaak Inhoudsdeskundlgen aanwezlg on het thema toe te lichten.

In de erste stageper lode bleelk $\infty$, dat studenten behoefte hadden on bulten de onderwijsgroepen Individueel contacten te hebben met de hulsarts-begelelder. Het geplande aantal wan 5-6 gesprekken bleek echter niet haalbaar te zijn. Uit de verslagen kan worden opgemaakt, dat genlddeld ongeveer 3 gesprekken met de student gevoerd werden. Naast een terugkoppel ingsfunct lo ten aanzlen van de door de student Ingeleverde Journaals, vermelden de hulsarts-begelelders, dat in deze gesprekken regelmatlg kwestles als persconlljk functloneren on beraepskeuze na het afstuderen ter sprake kwamen. 
4.4. Gegevens over de tljdsbested Ing van studenten.

4.4.1. Beschrijuling van de registratle van tljdsbesteding *

Bil] het plannen van de stage-opzet zijn door de planningsgrcep oen artal veronderstellingen geult over de wenselllke tlJdsbestedling van studenten. Zo werd gesteld, dat ultgegaan werd van een 40 -ur lge werkweok, warwan ongever 20 uur besteed diende te worden aan actlvitellten in de hulsartspraktljk. Er werden per weok twee groepsbljeenkomsten gepland en de over lge tlljd werd aangemerkt als zelfstudletild.

Gezlen het gegeven, dat nog nlet eerder ervarling was opgedaan met deze stage-opzet, was de planningsgroep benleuwd in hoeverre de feltelljke tIjdsbesteding van studenten overeenstemde met de geformuleerde ultgangspunten. Binnen het keder van de programma-evaluatlio lis daram ean

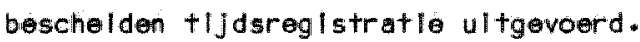

Ult de literatuur over tijdsregistratle in onderwiJsinstellingen (Muggen, 1972) is bekend, dat studenten het bljhouden wan bestede +IJd over het algemeen als belastend ervaren. Op grond hiervan ém rekening houdend met het reeds onvangrljke aantal gegevens, dat studenten in het kader van de programma-evaluatle dlenden to verschaffen werd gekozen voor eon benaderling, warblJ steeds oen deell van de studenten gedurende een week hun tijdsbesteding bljhlelden op een daartoe ontwlkkelld + Ijdschriffformul lor. Uit ledere onderwljsgroep vulden wekellijks twee studenten een formuller in, zodat ledere student in princlpe 4 maal een week zlJn tijdsbesteding dlende blj to houden. Aangezlen in de erste stageperiode 4 onderwlJ sgroepen gevormd waren en in de tweede stageperiode 3 graepen, zouden op deze wlJze wekellyks 8 respectlevellJk 6 +ljdsreglstratles beschlkbaar zljn. De hier gekozen methode Is door Everw In \& Muggen (1973) onschreven als de "derde methode" " warme wordt asngegeven dat hat gat on ean mengvorm van de langltudinale methode lledere student vult gadurende de gehele perlode oen formuller $(n)$ en de transversale methode (onafhankelljke steekproeven vari studenten varschaffen gedurende én deell per lode +ljdsgegevensi).

Het klelne a antul studenten, det wekelljks an de reglstratle dilende mee te doen bracht met zllch mee, dat bljzondere andacht besteed diende to worden an de particlpatle van studenten aan dit onderdeel van de programe-evaluatie. In plaats van de veelal toegepaste methode, warblj ultglfte en inzameling van formulleren per post geschledt, werd gekozen voor het persoonl iJk overhandlgen en Inzamelen van formu- 
lleren tijdens anderwlj sgroepsblJeerkomsten. Indlen de volgens het opgestelde invulschema aan de beurt zlJ nde student nlet aanwezlg was, werd het formuller ultgerelkt an de eerstvolgende op de $11 \mathrm{Jst}$ voorkomende student.

Methodologlsche wensellJkheden, dle met name van bellang zijn on betrouwbare vergelljkingen tussen subper lodes iln de stage mogelljk te maken zljn hlerblj ondergeschlkt genazk aan het streven on in leder geval een betrouwbaar globaal inzlcht to krljgen in de tljdsbestedling van studenten.

Aangezlen de eerste stageweok en introducerend karakter had en nlet als een "normale" stageweek beschouwd kon worden en aangezlen het onderzoek on practlsche redenen pas in dle bek blJ de studenten kon worden gelintroduceerd heeft de reglstratle betrekkling op de tweede tot en met de laatste stageweek. Tijdens de twoede stageper lade zljn geen gegevens verzameld in de 70 stageweek, aangezlen studenten deze carnavalsweek als vacantleweek beschouwden (zoals cok gebrulkelljk is in de eerste wier studlejarenl. Het gebrek aan duldell Jke afspraken vooraf tussen faculteit en studenten op dit punt il lustreart over lgens hoe de onderwljsplanning in een nleuwe facultelt to lijden kan hebben van klinder zlekten.

In de rapportage zljn de resultaten steeds gecorrigeerd voor het ontbreken van deze gegevens.

Studenten dienden hun tijdsreglstratie bij te houden op het in flguur 4-2 wergegeven formuller. Herop zijn de bellangrljkste cetegorieän activitelten, die de studenten gedurende hun stageperliode ondernemen, aangegeven.

\subsubsection{Resultaten.}

De responslepercentages bedroegen 931 voor de eerste stagegroep en $77 \%$ voor de tweede stagegroep. Het lagere responslepercentage tijdens de tweede perlode wordt vooral veroorzakt door het wisselen van tIJdstlp van groepsbljeenkonsten in de loop van dle stageperlode, wardoor de distributie van formulleren tijdelijk in de knel raakte. Over het geheel genomen is de respons bevredigend to noemen.

BlJ de analyse vam de ingevulde formulleren bleak, dat en antal categorlean dermate welnig benut werden, dat afzonderlifke rapportage 
Figuur 4-2: Model tijdsireglstratleformul ler.

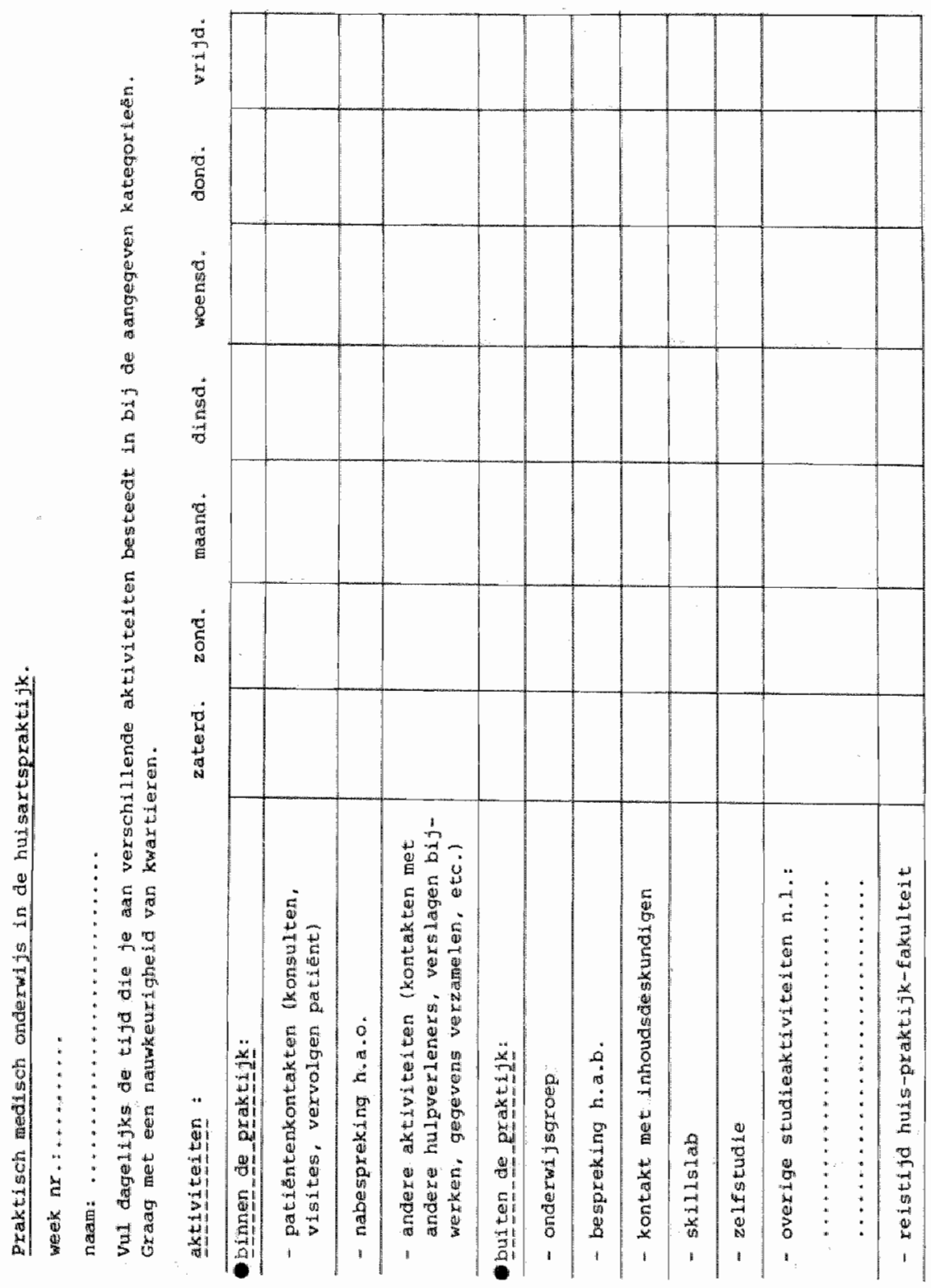


over deze categorlë̈n welnig zlnvol is. Ult gesprekken met studenten is gebleken, dat zlj de moverlgo activitelten blinnen de praktljkm be schouwden als een loglsch ultvloelsel van de contacten met patilenten. Het onderverdelen van deze activitelten werd als "onnatuur I lllk" rveren. Op grand hilervan zilln deze categor leän samengevoegd. De categor le "nabespreking met de hulsarts-opleider" is als afzonderlljke categorle gehandhaafd. De activitelten buiten de praktljk zijn in de rapportage ter uggebracht tot de categorleën "zell fstudle" en al le overlge activltelten. De relstijd is als afzonder lijke categor le gehandhatd. In tabel 4-5 zijin voor de belde stagegroepen afzonder lijk de +ljdsbestedingsgegevens over de gehele stageperlode samengevat, warbll de gemlddelde tijd per week als ultgangspunt is genomen.

Tabel 4-5: Gem Iddelde tIJdsbesteding in uren per stageweok.

Groep 1 Groep 11*

Totall aantal reglstraties

89

51

Respons percentage

$93 \%$

778

activitelten binnen de praktljk:

uren per week

patient-contact

m 19.0

mi 18.6

nabesprekling $\mathrm{h} \cdot \mathrm{a} \cdot \mathrm{o}$.

s $\quad 6.66$

s 5.16

m 2.1

m 1.7

s 1.28

s 1.15

activiteiten buiten de praktijk:

zel fstudle

$\begin{array}{llll}\mathrm{m} & 10.6 & \mathrm{~m} & 8.6 \\ \mathrm{~s} & 5.46 & \mathrm{~s} & 5.61 \\ \mathrm{~m} & 6.6 & \mathrm{~m} & 5.2 \\ \mathrm{~s} & 4.69 & \mathrm{~s} & 3.45\end{array}$

total netto studietijd

m 38.3

m 34.1

s 8.56

s 7.20

relstidd

$\begin{array}{llll}m & 5.4 & \text { in } & 4.2 \\ s & 2.90 & s & 1.61\end{array}$

* Gegevens gecorrlgeerd voor het ontbreken van gegevens met betrekking tot de vacantleweek (zle tekst paragraef 4.4 .1$.$) .$ 
De totale genlddelde netto-studlletljd van de eerste stagegroep kont redelljk in de buurt van do 40-urlge opzet van het programma, zeker wanneer men anzlenlijke relstljd daarblj in anmerking neent. De tweede stagegroep besteedde duldell llk minder tija aan de stage. In belde stageperloden besteedden studenten ongeveer 20 utur per week aan activitelten blnnen de praktllk warlin ze werkzaam waren. Deze tijdsbesteding stemt dus overeen met de door de planningsgroep geformuleerde verwachting. De tijd dle door studenten besteed werd aan activitelten bulten de praktlJk komt voor de eerste stagegroep nagenoeg overeen met de verwachting, maar bllJft voor de tweede stagegroep achter: de tweede stagegroep besteedde minder tijd aan zelfstudle, terwIJI ook de tljd besteed an over lge actlvitelten (met name de onderwljsgroepsbifleenkomstent lager uitwlelen. De verschlllen tussen de belde stagegroepen in netto-studietljd blijken bij toetsing signiflcant to zijn ittoets, tweozljdige toetsing, $p<.011$.

In princlpe kunnen dergelljke verschlllen veroorzeakt worden door selectleve ultval van gegevens in de tijdsreglstratle: de respons in de tweede stagegroep was Immers lager dan In de eerste stagegroep. Eerder werd or echter op gewezen dat een belangrljk deel wan deze verschlllen In respons kan worden toegeschreven aan het mislopen van afspraken over versprelding en inzamelling van gegevens. Dat hlerdoor, gezlen het kleine antal registratles, fluctuaties in de gegevens optreden, Is nlet ultgesloten. Anderzljds is dit goen warschljnlljke verklarling, aangezlen de geringere $+\| j d s b e s t e d i n g$ over de gehele perlode warneembaar Is, terwlj| de verm Inderde respons zlch vooral in een tweetal wethen voordeed.

Bovendlen zlJ $n$ de verschlllen dusdanlg, dat lle non-respondenten in de tweede stagegroep een gemiddelde netto-tIjdsbesteding van terminste 51 uur dienden te hebben on de verschlll len goed te maken. Dergell ljke studletijden zljn blj de respondenten nlet gevonden.

Ult de eveneens geregistreerde reistijden blljkt dat de verschillen daardoor nllet verklaard kunnem worden. Het tegendeel is eerder waar: de eerste stagegroep heeft gemlddeld meer rellstljd nodig gehad dan de tweede stagegroep.

Een andere werklarlingsmoge|ljkheld voor de gevonden verschlllen dle losstaat van de stege-opzet is, dat de erste stagegroep minder afwezlgheldsbehoefte kende, aangezion de stage ansloot op de vacantleperlode, term|Jl twede stagegraep deze stage volgde no een erdere stage van zes maanden. De actles, dlie met succes gevoerd werden om een onderwijswrlje week tijdens de carnavalsperlade te krljgen zouden hierblj als ondersteuning kunnen worden beschouwd. Dok deze werklaring 
Is nlet houdbaar wanneer men de tljdsgegevens in flguur 4-3 betk Ijkt. In deze figuur zijn de reglistratlegegevens gesplitst in 4 per loden van 3. weken (in de gegevens van de tweede stagegroep zijn deze gegevens gecorrigeerd voor de vacantleweek). De vacantleweek wel, zoals aangegeven, in de tweede perlode van drle weken. Wanneer "vermoelaheld" de aanlelding tot en verminderde tljdsbesteding zou zlJ $n$, dan mag men verwachten dat vöör de vacantleweek de verschlllen in tljusbesteding tussein belde groepen groter zljn dan erna. Dit is echter nlet het geval: de verschlllen in tljdbested ing zlJn verwaarloosbaar voor de vacantlleperlode Julst aenzlenlllk na dle perlode.

Concluderend kan gestelld worden, dat de gevonden verschillien in tijdsbesteding nllet verklaard kunnen worden door de wijze ven gegewens werzamelen, de mogelljke verschllllen in relstljd of de platsing van de stageperiode op zlch. Wanneer dergelljke factoren, die nlet of nauwelliks samenhangen met de stago-opzet, geen verklarlingsgrond bleden, dan blifft als werkllarling over, dat de stego-opzot voor de oerste stagegroep "ultdagender" was en met name meer tot zelfstudle en tot het ondernemen van andere studleactivitelten bulten de praktijk anlelding gat. Dit sluit aan blJ de eerder gemakkte opmerkllng, dat de tweede stagegroep over het geheel genomen lets minder positlef over de stage cordee Ide.

Figuur 4-3 is nlet alleen Interessant in verband met de zojulst bespraken verschillien, maar ook ondat hleruit kan worden afgelezen, dat belde stagegroepen na de helft van de stage een dellende tendens in hun tijdsbesteding vertonen. Wanneer men tljdsbesteding. zoals hilervoor vermeld, beschouwt als een indlcator van de "ultdagendheld" van de stage, dan blijken studenten in het verloop van de stage $\mathrm{m} /$ nder gest muleerd te worden.

Aangezlen de tiljdsreglstratle wen wan de welnlge min of meer contlnue ultgevoerde vormen van programa-evaluatle is in dit onderzoek, is het moell ljk atnvullende evidentle voor deze veronderstelling aan to woeren. Wel siluiten deze gegevens aan blj de mondellinge Informatio, die door de hulsarts-begelelders ziljn gedaan over de gang van zaken dens de stage. Zlj rapporteerden een dallng van de belangstelling van studenten cmistreaks het midden van de stage. In tegenstelling tot de voortdurend dalende tendens in de +ijdsbestedingsgegevens waren zij echter van cordeel, dat tegen het ellnde van de stage sprake was van een opleving in de belangstelling. Achterat is het $J$ amer, dat in thet onder zoek geen instrumenten zljn opgenomen, waarmee de opinles van 
Fllguur 4-3: Genlddelde tljdsbesteding per weok ultgesplitst over 4 perloden wan 3 weken voor stagegroepen I en 11.

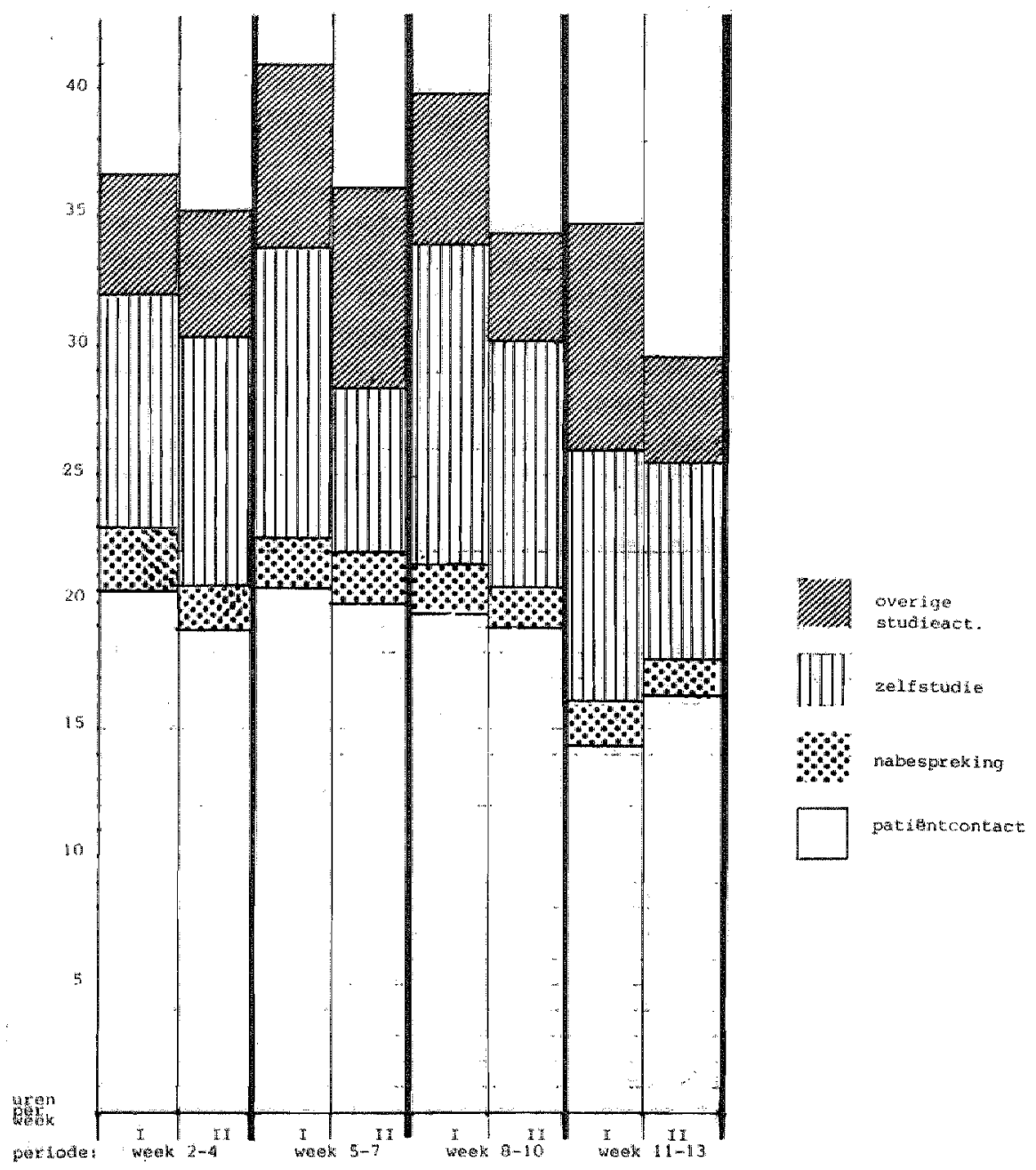


hulsarts-begelelders over het verloop van de stage moer systenatlsch zlin vastgelogd.

4.5. De huisarts-oplellders.

De medewerking van hulsartsen aan de reallsatle van het stageprogramma is vanaf het eerste monent een belangrljk punt van zorg geweest voor de facultelt. Het beperkte aantal hulsartsen, dot werkzaam is blnnen het werkgebled van de facultelt der geneskunde makt de realisatle van dergelijke stege kwetsbar. Het op zlch verheugende gegeven, dat na en Intensleve wervingscampagne, voldoende oplelders voor het oerste stagejaar beschlkbaar waren, betekent Immers nog niet, dat oen dergel lljk programa gedurende lengte van Jaren on ook nog met stijgende studentenaantallen, magelljk bl ljkt te zljn. Van groot belang voor het wels lagen van de stage is dan ook, dat de hulsarts-oplelders voor het overgrate deel zeer te spreken ziJn over de samenwerking met de student on hun aanezlgheld in de praktlyk, zoals blijkt uit de gegevens in tabel 4-6. Tegen de achtergrond van de scepsis ten aanzien van het opleldingsmodel van de facultelt der geneeskunde, dle ook bly hulsartsen in Limburg aanwezlg was, is deze positleve ultkomst opmerkel ijk.

Uilt de beantwoording van de vragen door studenten met betrekkling tot hun hullsarts-oplelders (bljlage 1, vraag $12+/ m 22$ ) kan worden geconcludeerd, dat $\infty \mathrm{k}$ de studenten hun oplelder duldelljk waardeerden. Ernstige problemen tussen opleiders en studenten deden zlch zelden voor. De regelmatlge contacten tussen de facultelt en de opleiders $z / J n$ mede op gerlcht dergelljke problemen in veen vroeg stadlum te sllgnalleren en te woorkomen.

U1t de gegevens blijkt cok, dat oplelders meer tijd aan hun tak besteedden, dan ze hadden verwacht. In het onderzoek is nlet getracht op systematische wijze hilerover gegevens te verzamelen.

Uith het tljdsbestedingsonderzoek onder studenten kont naur voren. dat opleiders genlddeld ongeveer 2 uur per week besteden aan nebespreklingen. Uit de antwoorden van de oplelders in tabel 4-6 valt af te lelden, dat met name de Impassing van de nabesprekingen moelte kostt. De aan de nabespreking bestede tljd is geniddeld dan ook lager, dan door de plannlngsgroep noodzakel ljk geacht werd. Het onderhouden van contacten 
Tabel 4-6: Dordeel van thulsarts-oplelders over de aanezighelid van een student in de praktijk.

Groep 1 Groep II

1. De samenwerking met de student ver ll lep goed.

$\begin{array}{ll}m=1.3 & 1.5 \\ s=.44 & .94 \\ m=2.3 & 3.1 \\ s=1.33 & 1.34\end{array}$

oplelder heeft mij meer $+1 \mathrm{Jd}$

gekost dan lik werwacht hed.

B. Do anwezligheld van de student

$$
m=4.0
$$

4.1

heb $1 \mathrm{k}$ als een last ervaren.

$s=1.02$

.89

1. De nabesprekingen $\mathrm{kwamen}$ vaak in

$m=3.5$

3.4

de knel.

$s=818$

1.16

J. Het nabespreken van de Journaal-

$m=4.6$

4.5

patiënten heeft volgens milj wel-

$s=.65$

.76 $n \lg z \ln$.

(antwoorden op een 5-puntsschaal: $1=$ volledig eens, $5=$ volledig oneons).

met de hulsarts-begelelder en het deelnemen aan bijeenkomsten met andere huisarts-oplelders kost naar schatting een uur gemlddeld per stageweek. Daarnaast veroorzaakt de aenwezlgheld van de student en zekere wertragling in de dagelijkse werkzaamheden. Een schatting wan viJf uur gemlddeld per week, zoals dle door een antal oplelders gegeven is voor hun totale geinvesteerde $+11 j d, 11 \mathrm{jkt}$ dan ook realist $1 \mathrm{sch}$. Deze +1 Jdsinvesterling komt in hen hulsartspraktljk vrljwel geheel bovenop de normale werklast, alangezlem de student in princlpe geen werkzamhedem verrlcht, dle tot oen takwerllchtlng van zljn oplelder lelden. Het is tegen dle achtergrond ook begrijpelljk, dat in een aentall opleldingspraktlJken de nabespreklingen met de student in felte neerkwamen op tussendoor een aantal opmerkingen maken.

Het is niettemin opvallend, dat nagenoeg alle huisarts-oplelders berelld bleken opnieuw als opleider op te treden. 
De motleven wan oplelders am zich beschlkbaar to stellen voor dit stageprograma en om het oplelderschap te continueren zljn nlet systematisch onderzocht. Uit de gesprekken woorafgand an de stage 10.a. tijdens de didactlsche voorbereldingl en tijdens de groepsbljeenkomsten met de opleiders gedurende de stage kunnen wel en antal motleven gedestllleerd worden. Een aantal, met name oudere, hulsartsen geeft an vanult een zekere professionele opvatting mee to doen: als ervaren professlonal hoor je je ervaring ter beschikking te stellen van studenten. Anderen benadrukken het belang van ben betere medische oplelding, dle jonge afgestudeerden voor minder grote problemen in de praktljk plaatst, dan zij zelf ervaren hebben. Wer anderen, met name hulsartsen in solopraktijken, noemen het doorbreken van betrekkeIIJk isolement, warin zij werken, als motlef. TiJdens de stage werd door een aantal opleiders ook genoemd de stimulans voor het elgen werk, dle van de aanwezlgheld van een student ultgaat; het oplelderschap kan lelden tot reflectle op het elgen handelen en Is prikkel tot studle.

De grcepsbesprekingen met de huisarts-oplelders boden gon goede gelegenheld de eerste ervarlingen met elkaar ult to wisselen. Allerlel praktische punten, zoals het selecteren van patiënten, hat maken van een dagindeling, het betrekken van de student blJ allerlel act|vitelten in de hulsartspraktljk konden aan de orde komen. Daarnaast werd gediscussieerd over zaken als: hoeveel vrijheld geef je de student, welke elsen kun je als opleider stellen, wat mag lk van een vijfdeJaarsstudent verwachten, etc.. BlJ veell oplelders bestond een dulde$11 \mathrm{jke}$ behoefte on feedback te krljgen over hun functioneren. 
Hoofdstuk 5

\title{
Medische vaardigheden en competentle
}

\author{
5.1. Inlelding.
}

In het vorlge hoofdstuk is oen overzicht van de gang van zaken tIjdens de stage gepresenteerd. Aan de hand van de programa-ewal uatlevragenlljsten, de Journals en het tijdsbestedingsonderzcek is getracht een beeld to schetsen van datgene, wat studenten tijdens de stage doen. Preclezer geformuleerd: zaken waar studenten tijdens hun stage mee in aaniraking komen.

In dit hoofdstuk wordt nader ingegaan op een aantal aspenten van de stage, dle samenhangen met het brede gebled van medische waardigheden en competentle.

In de eerste plaats is getracht te inventariseren welke vaardigheden studenten in de hulsartspraktijk toepassen. Die informatle is cruclaal on te kunnen beoordelen of en van de belangrljke uttgangspunten varn de stage, namelljk de actleve partlclpatle van de student, feitelljk tot zlljn recht komt. Aangezlen de planningsgroep blj de start van de stage nlet zeker was, in hoeverre deze uitgangspunten op alle stagepleatsen halbaar zouden bl IJken, diende de dataverzamelling zodanlg te $z \| j n$, dat tussentijds zowel aan de studenten als aan de hulsarts-oplelders informatie kon worden verschaft.

De tweede doelstelling van dit hoofdstuk Is na te gaan, wat de kwalltelt wen het handellen vam studenten is op het gebled van medische vardlgheden competontle binnen het kader van de stage.

Het antwoord op deze twede vraag kan slechts bemaderend gegeven worden, ondat geen hanterbare toetsvorm beschlkbaar is on de ultgebrelde hoveelheld valdigheden te meten (Newble, 1976); voor het begrlp medische competentle geldt darenboven, dat onderzoek op dit terrellin als conslstente ulthonst heert, dat competentie altijd context specliflek is, met andere woorden dat competentle in een bepalde situatle en slechte voorspeller blijkt te zijn voor competentie iln een nleuwe sltugtie (Elsteln *a., 1979). 
Gegeven deze situatle is getracht en aantal gegevens te verzamelen met behulp van verschlllende meetmethoden, elk met hun elgen starke en zwakke kanten. Daarblj is ultgegaan van ven vertal benaderlingswijzen, die in het medisch onderwlys worden gebrulkt on vaardlghoden en comper tentio te meten.

In de erste plats is er de mogellikheid om studenten een steekproef van vaardlgheden in een gecontroleerde sltuatle te llaten ultwoeran (doe op deze petliënt een bulkonderzoek etc.). Deze methode maakt deell ult van een aantal examenprocedures in de Verenlgde staten en GrootBrittanlë (Harden en Gleeson, 1979) en maakt sinds 1980 deel ult van de arts-examenprocedure van de facultelt der geneeskunde in Maastricht. Het prableem bij deze werkwllze $\| s$, dat onvoldoende onderzocht is in hoeverre de steekproef van vaardigheden lets zegt over het totale vaardigheldsn veau van de student.

Een andere benadering is on vaardigheidsaspecten binnen de normale stagesettling tijdens en patlënt-student-contact to observeren en te warderen. Deze situatle staat dichter bij de praktijk, maar heeft dezelf fe bezwaren ten aanzien van het karakter van een stoekproef.

Een derde methode is om aan artsen, asslstenten, etc., die de student gedurende een bepaalde periade in hun praktljk hebben, to vragen het globale vaardlighelidsniveau to willen warderen. Deze methode is vrlJ gebrulkelljk in het medlsch onderwijs. Het voordeal van deze methode is dat de beoordelaar een grotere varlëtelt van sltuatles in zijn oordeell kan betrekken. Het nadeel is de oncontrolaerbaarheld van de becordel ing.

De vierde methode is om studenten zelf te vragen welk vaardigheldsnlveau zij bezitten. Het voordeel van deze methode is, dat in princlpe een cordeel over alle vaardigheden gespeciflceerd gevraagd kan worden. Het nadeel is dat een zelfbecordel Ing geen objectleve bas is heeft. Well kan deze methode inzlcht geven in het vertrouwen in elgen kunnen en eventuele veranderingen daarlin. In een onderzoek nar de effecten van de beroepsoplelding voor hulsartsen in Groningen werd met behulp van deze mothode gewerkt (Centrum voor Onderzoek van het Wetenschappo$1 \mathrm{j} k \mathrm{k}$ Onderwis Gron Ingen (COwOG), 1977).

In dit onderzoek is een aantal methoden toegepast om het valardighellsnlweau en de weranderlingen dearln te meten. De viler hllervoor genomdé methoden zijn alle gebrulkt:

1. Er is ven vardligheldscheckll ist ontwlkkeld, dle door de stuidenten is ingevuld aan het begit, halverwege en an het elnde van de stage $(z$ le par. $5 \cdot 2$.$) .$ 
2. Aan de hulsarts-oplelders is glabal oordeel over he vardigheldsmiveau van de student gewrabd lzle paragraaf 5.2.).

3. De hulsarts-opleiders werd gevraagd on tilldens de stage tweenael een student-patlënt-contact nauwlettend to obserweren en de resultaten in te wullen op en becordelingsformuller (z le par. 5.3.1..).

4. Hulsarts-oplelders en hulsarts-begelelders hebben vaardlgheldsaspecter tijdens een student-slimulatle-patlënt-contact geevallueerd (z) par. 5.3.).

5.2. Zelt-oordelen wan studenten en het glabaal cordeel van oplelders.

5.2.1. De vardigheldscheckllist.

In deze paragraaf staat de eerste methode, de checklistmethode, centraal. Voorts worden de globale cordelen van de hullisartsopleliders gerapporteerd.

Bij de samenstelling van de vaardigheldschecklist is geen gebrulk gemaakt van de door het COWOG ontwikkelde checkllst wan 142 vaardigheden. De voorkeur werd gegeven aan het samenstellien van een $11 \mathrm{Jst}$, war In vaardigheden een benaming hebben gekregen, dle overeenstemt met de naamgeving van het Skll Islab voor dergelljke vaardigheden.

Het woordeel van deze werkwljze is dat aanglesloten wordt op het referentlekader van studenten; $u l t l e g$ en speclflcatle van vaardigheden IIs overbodig, aangezlen de naamgeving verwljst naar onderdelen van de vaardlgheldstraining. In dit programma wordt veelal gewerkt aan de hand van een zogenaamde standaard, dle de inhoud van de vaardigheid omschrljft (Lodewlck, 1978). In overleg met het Skllls lab is on IIJst met 65 relevante vaaraigheden ontstaan. Deze $11 \mathrm{j}$ st is te vinden in bljlage 2. De studenten werd gewraagd bil ledere vaardighell het beheersingsniveau aan te geven door het aankrulsen wan een van de drie antwoor dmoge I I kheden:

Score 3: zelfstandlg beheersen, dat will zeggen de vaardigheld zonder steun of contróle door een docent of begelelder kunnen verrlchten bll en patient.

Score 2: onder toezllcht beheersen, de student verwacht er wel lets van terecht te brengen, maar meent enlge steun of correctle nodilg te hebben. 
Scare 1: onvoldoende beheersen, de student meent niet in stat te zljn de betrokken vaardigheld op en patlënt toe te passen.

Halverwege en aan het ell nd van de stage werd aan de studentem tevens gevraagd on blj iedere vaardigheid an te geven of $z \mid \downarrow d l e+1$ dens de stage hadden toegepast. Een nadere speciflcatle wan het aantal keren is nilet gewraagd. De tweede stagegroep heeft deze wraag ook aan het beg In van de stage beantwoord on en inzlcht te verkrljgen in de mate war in vaardigheden in de zes maanden klinische stage waren toegepast. Deze vragenllijst is zodanlg opgezet, dat de invultijd ongeveer $10 \mathrm{mi-}$ nuten bedraagt.

\subsubsection{Resultaten.}

De gegevens, die met behulp van de vaardlghedenchecklist verzemeld zijn, kunnen op versch\|llende manteren geanalyseerd worden. Al lereerst kan men per student door sommatle over alle vaardigheden oen totaalscore berekenen, die het subjectleve beheersingsnlweau representeert. Deze score kan als en indlcatie voor het vertrouwen in elgen kunnen worden opgevat.

In tabel 5-1 zijn de totaalscores vermeld voor de belde stagegraepen van respectievelljk 24 en 21 studenten.

Tabel 5-1: subjectlef beheersingsniveau met betrekking tot 65 vaardligheden.

$(\min \cdot$ score $=65, \max \cdot \operatorname{scor} \theta=195)$

Groep $1 \quad$ Groep 11

$\begin{array}{lllll} & m & s & \text { in } & s \\ \text { voor de stlage } & 140 & 10.9 & 149 & 11.3 \\ \text { halverwege } & 154 & 17.4 & 157 & 13.0 \\ \text { eind stage } & 160 & 18.4 & 165 & 13.2\end{array}$

Hoe globaal deze resultaten ook mogen zlJn, ze geven aan dat groep I 
an hert begin van het PMOH, naa het cordeel van de studenten zelf, nllet voldoet aan de verwachtingen van de plannlingsgroep met betrekking tot het wardigheidsniveau. Een score van 140 impll ceert namelijk dat men gemiddeld over alle studenten en al le vardigheden meent de vaardigheden alleen met steun of correctie te kunnen toepassen. Dit beglinmilveau mag teleurstel lend genoemd worden. Tljdens de stage blljkt het valardigheldsniveau to verbeteren.

Bij groep I valt op dat dit kennelljk niet blj al le studenten in even grote mate gebeurt, gezlen de toename in de sprelding.

Gezien het felt, dat groep 11 bij de aanvang van de stage reads 6 maanden ki inlsch onderwils heeft genoten is de aard van de verschll len tussen belde groepen geheel in de ll Jn van de verwachtingen.

Een nader inzlcht in het vaardligheldsniveau kan worden verkregen door ne te gaan hoeveel vaardlighedien gemlddeld nlet beheerst worden. Wanmeer personen aangeven een bepaalde vaardigheld nlet te beheersen, dan kan dit als hen harder gegeven worden beschouwd dan de overilge twee scor Ingsmogel IJkheden, aangezlen de interpretatleruimte minder groot Is. De gegevens betreffende het aantal keren dat een vaardighell als "nlet-beheerst" werd gescoord is voor de dr le afnamegelegenheden aangegeven in tabel 5-2.

Tabel 5-2: Aantal len niet-beheerste vaardlgheden per student. $(\mathrm{min} \cdot \mathrm{scor} \theta=0, \max \cdot \operatorname{scor} \theta=65)$

Groep 1 Groep II

$\begin{array}{lcccc} & \mathrm{m} & \mathrm{s} & \mathrm{m} & \mathrm{s} \\ \text { voor de stage } & 14 & 5.9 & 10 & 6.7 \\ \text { halverwege } & 9 & 5.6 & 8 & 4.9 \\ \text { alnd stage } & 9 & 7.8 & 6 & 5.2\end{array}$

De eerder gemakte opmerkingen over het vaardigheldsniveau blj de start van het PMOH worden door deze gegevens nog eens bevestlgd. Tussen de beide groepen I en 11 treden dezelfde verschlllen aan het llicht, dle oerder werden geconstateerd.

Belde tabellen geven aan dat de studenten na een stage in de klinlek 
hun vardigheldsniweau in het PMos op een hoger nlveau brengen, dan studenten, dle nog geen kllnische stage gelopen hebben.

Het wegwerken van een antal deficlëntles door groep 1 gebeurt met name in de eerste helf van de stage.

opvallend in de zelfoordelen van studenten is het fenomeen, dat no zes

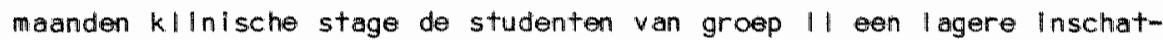
ting van hun vaardlgheldsniveau geven dan hun collega's, dle drle maander PMOH achter de rug hebben, terwiJl men op grond van het verschll in programaduur eerder het angekeerde zou verwachten.

Zel foordelen behoeven echter nilet noadzakelljkerwils overoen te stemmen met door anderen constateerbare felten. Anders gezegd zouden deze verschillten cok kunnen berusten op verschillien in de wijze waarop de student al dan niet bevestigd is in zijn kunnen.

Het zell foordeel wan studenten over het glabale vaardlgheidsnlveau kath worden aangevuld met het cordeel van de hulsarts-oplelders. In tabel 5-3 zljn deze glabale cordelen weergegeven. Opgemerkt dlent te worden, dat deze vragen nlet geheel corresponderen met alle vaardigheden, die in de checklist voorkomen; naast gesprektechn ische vaardigheden en fysisch-dlagnostische vaardigheden bevat de checklist ook on antall therapeutische vaardigheden (O.a. E.H.B.0., oor ultspuiten, etc.).

Tabel 5-3: Globale cordelen over het vaardigheldsniveau wan studenten door de hulsarts-opleiders.

Groep I Groep II

$\begin{array}{llll}\text { na } 4 & \text { elnd } & \text { na } 4 & \text { elnd } \\ \text { weken } & \text { stage } & \text { weken } & \text { stage }\end{array}$

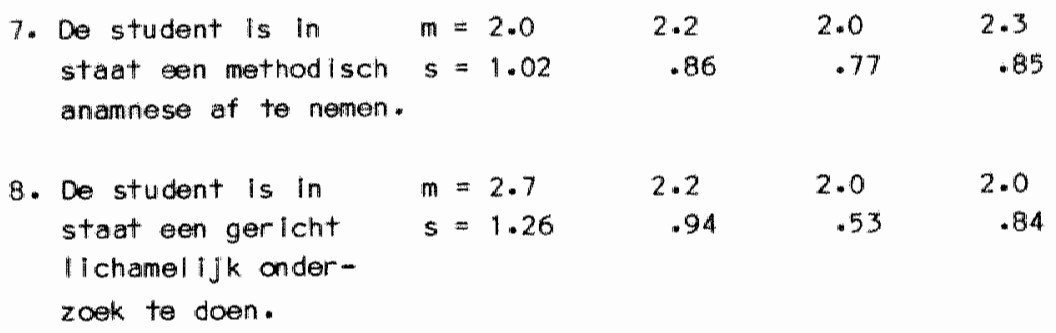

(antwoorden gegeven op een 5-puntsschaal, 1 = volledlg eens). 
In zlJn allgeneenheld zlIn oplleliders a an het elnd van de stage tevreden over het vaardigheldsnlveau wan de studenten. In dit opzicht stemmen de resultaten owereen met de zelfoordelen van studenten, zoals weergegeven in tabel 5-1. Dok tekent zlch het lagere beglnniveau van groep 1 ten aanzien van de fyslsch-diagnostlsche vaardigheden af.

De wardigheldschecklist kan ook op het nlveau van de afzonderlljke vaardigheden geanal yseerd worden.

In bljlage 2 ziln woor ledere vardlghell afzonderlljk de genlddelde beheersingsscores vermell voor de belde stagegrcepen.

In de tabellen 5-4 en 5-5 staen voor de respectievelljke stagegroepen de vaardigheden vermeld, die door de betreffende groep slecht tot matig beheerst worden aan het begin en aan het elnd van de stage cals grens is hier genomen een gemiddelde score lager dan 2).

Uit de tabel len 5-4 en 5-5 blljkt duldelijk dat de lacunes in vaardigheden a an het begin wan de stage PMOH voor belde groepen ean grote mate van overlap vertonen. Dlt wijst erop dat deze vaardigheden onvoldoende aandacht hebben gekregen in het voorafgaand onderwljs.

De Inwloed van het Praktisch Medisch Onderwijs in de kliniek blljkt ult het nlet woorkomen wan een aantal vaardigheden blj de start wan de tweede groep. Dilt geldt bllvoorbeeld voor wondverzorging, hechten, onderzoek van hand, pols, enkel en voet en E.H.B.O. blj breuken. Woorts heeft de tweede groep een groter vertrouwen in de elgen gesprekstechnlsche vaardigheden.

Uit het verdwlinen van een groot aantal waardlgheden ult de lacune11Jst aan het einde van de stage (zle tabel 5-4 en 5-5) kan worden afgeleld, dat studenten in het PMOH kennell jk de gelegenheld krijgen on hun vaardigheldsnlveau te werbeteren.

Dit kan echter directer gedemonstreerd worden door presentatle wan de gegevens . die betrekking hebben op de vraag in hoeverre de studenten de 55 vaardigheden in de praktljk hebben toegepast. Zaals reeds in de Inlelding werd vermeld is ultsluitend gevraagd óf de betreffende vaardigheden zijn toegepast; er is niet gelnventar lseerd hoo vaak dit het geval is geweest. 
Tabel 5-4: Overzlcht van slecht tot matig beheerste vaardigheden blj het begin en aan het elnd van de stage, gebaseerd op de scores van 24 studenten ult de erste stageper lode.
Begin
EInd

bloedultstrijkje maken

leukocyten tellen

gramkleuring en becordeling gramkleuring en becordeling

urine sediment beoordelen

ander zoek van pols en hand

onderzoek $v$ an enkell en voet

onder zoek van de zwangere

onderzoek van de zwangere

anticonicept lemethod leken

al gemeen oogonder zoek

fund uscop i seren

oogbol drukmet ing

fund uscoplseren

oogbo I drukmeting

oog spoelen/verb / nden

oogspoelen/verbinden

oor spoelen/dr uppelen

onder zoek neus en bljholten

gesprekstechn.: emoties

gesprekstechn.: informatle

versch.

algemene hyglëne en wondverzorging

hechten

hechten

E.H.B.O. blJ breuken on

distorsles

E.H.B.O. bif verglftigingen

E.H.B.O. bif vergiftingen

E.H.B.O. bIf werdrlnking

verbanden

inbrengen mayo-tube

Inbrengen mayo-tube

E.H.B.O. vervoer

E.H.B.O. vervoer

maaghevelen

maaghevelen 
Tabel 5-5: Owerzlcht van slecht tot matlg beheerste vaardigheden bl] het begin an aan het elind wan de stage, gebaseerd op de scores van 21 studenten uit de twede stageperlode.

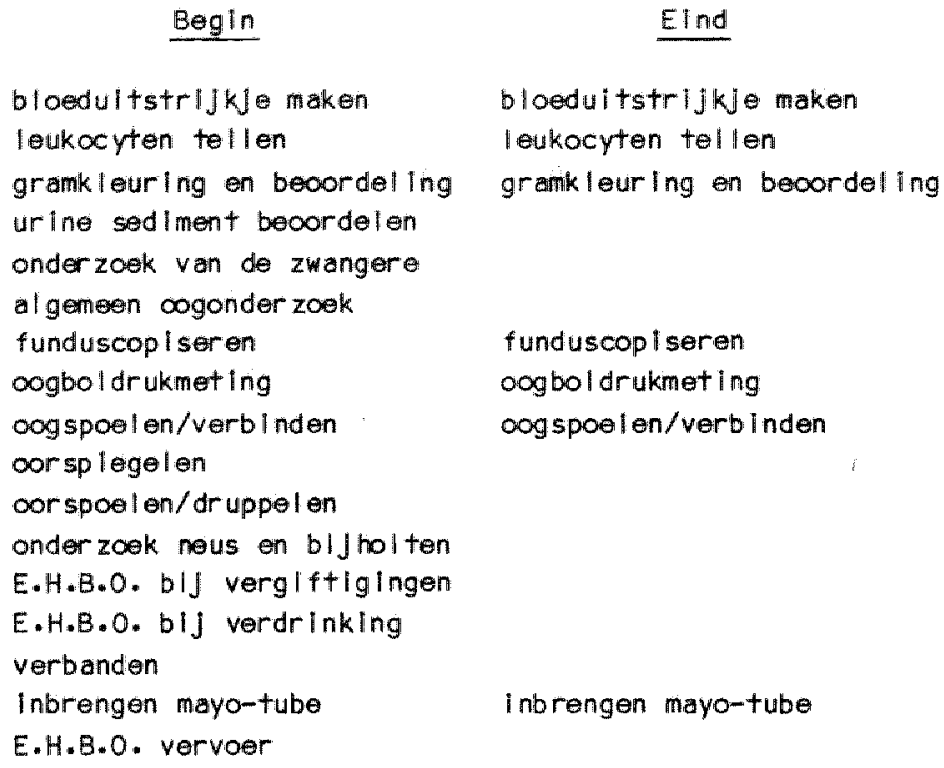

fund uscop I seren oogbol drukmet ing oog spoelen/verbinden

In tabel 5-6 staat voor belde stagegroepen vermeld hoeveel van de 65 vaardigheden halverwege en aan het elind van de stage in de praktijk waren toegepast.

Tabel 5-6: Gemiddeld antal toegepaste vaardigheden (maximum $=65$ ).

$$
\text { Groep I Groep II }
$$

$\begin{array}{lllll} & \mathrm{m} & \mathrm{s} & \mathrm{m} & \mathrm{s} \\ \text { gehele kllnische stage } & - & - & 3.2 & 7.7 \\ \text { gerste hellft PMOH-stage } & 31 & 6.2 & 30 & 9.1 \\ \text { gehele PMOH-stage } & 35 & 7.0 & 38 & 9.4\end{array}$


Blj de beginmeting van de tweode groep kon tovens gelmuentarlseerd worden het aantal vaardigheden dat gedurende de zes maanden kllnische stage in de praktlJk werd toegepast. Deze gegevens zijn eveneens in de tabel verwerkt. Aan het ellnde van de stage geven studenten aun dat men gemlddeld meer dan 50\% van vaardlgheden in de praktijk heeft kunnen toepassen. Tussen beide grcepen bestaan betrekkelijk ger Inge verschl $\|-$ len op dit punt. Opvallend is nog dat studenten in zes maanden zlekenhuisstage 32 vaardigheden in de praktljk konden brengen, terwljt de gemiddelden over drie maanden PMOH 35 voor de eerste groep en 38 voor de tweede groep bedraagt.

Het gevarleerde klachtenaanbod van de hulsartspraktljk en de stage-opzet stelt studenten kennelljk in stast een breder spectrum van veardighaden in de praktijk te brengen.

Een gedetall leerder onderzoek van de waardigheden, die werden toegepast in het PMOH en de zlekenhuisstage (zle de gegevens van groep II, bijllage 2) geeft echter aan dat belde stages elkar duidelljk aanvulIen op het punt van de vaardigheden; er zijn vaardigheden, die in het PMOH nauwelljks in de praktljk worden gebracht, terwljl dat wel in de zlekenhuisstage het geval is. Een aantal waardigheden blijkt echter In bel de stages nauwell ijks aan de orde te komen, met name E.H.B.O.-vaardigheden.

In tabel 5-7 $2 \mathrm{lJn}$ voor belde stagegroepen de vaardigheden vermeld, dle door mindier dan 25\% van de studenten in de praktijk werden gebracht gedurende de stage.

Wanneer men tabel 5-7 vergelljkt met tabel 5-4 en 5-5 dan valt op dat naast de E.H.B.0.-vaardigheden de nlet-beheerste vaardigheden overeenstermen met de nlet-toegepaste vaardigheden. 
Tebell 5-7: Vaardigheden die door minder dan $25 \%$ van de studenten in de piraktljk ziljn toegepast in het PWoH.

Groep 1

bloedultstrl dkje maken

leukocyten tell

gramkleurling on beoordoling

frecesonder zoek op bloed

oogbo l drukmet ing

oog spoelen/verbl nden

hechten

mond-op-mond-boademing

hartmos sage

stablele zlJ|lgging

E.H.B.O. blj bloedingen

E.H.B.O. blj breuken

E.H.B.O. blj verbrand lingen

E.H.B.O. bll verglftlgingen

E.H.B.O. bl」 verdrinking

E.H.B.O. bilJ bewusteloze

inbrengen mayo-tube

E.H.B.O. verwoer

magghevelen
Groop II

bloedultstrljkJe maken

leukocyten tellen

gramk leurling en beoordeling

oogboll drukmet ing

oogspoelen/verbinden

mond-op-mond-beadem Ing

hartmassage

stablele zl]|lgglng

E.H.B.O. blJ bloedingen

E.H.B.O. blj breuken

E.H.B.O. blj verbrandingen

E.H.B.O. bij verglftiglingen

E.H.B.O. bly verdrlinking

E.H.B.O. bewusteloze

1 nbrengen mayo-tube

E.H.B.O. vervaer

maghevelen

5.2.3. Terugkoppel Ing van resultaten maar studenten en huisarts-oplelders.

Zoals in de inlelding van dit hoofdstuk al werd vermeld werden de resultaten ver zameld met behullp wan de vaardigheidschocklist tussentijds meegedeeld aan studenten en hull sarts-opllelders. De studenten ontvingen two weken na ledere afiname van de checkll st hun elgen beheersingsscore, de gemlidelde score van de totele stagegroep en eem overzlcht van vardigheden, dle door meer dan $75 \%$ van de stagegroep wel werd toegepast in de praktljk, mar door de betreffende student nlet werd toegepast. Het bellang van het cefenen en toepassen van vaardigheden werd regelmatig oor de hulsarts-begelelders aan de orde gesteld. 
De hulsarts-oplelders ontvingein geen gedetall leerde overzichten van de hiervoor genoende gegevens. In de tussentijdse besprekingen met groepen hulsarts-opleiders werden wel totalicljfers over toegepaste vardigheden gepresenteerd, teneinde in een gesprak nadere Informatie to verkrljgen waarom lets in een bepallde praktllk kennelljk well kan, wat elders nog nilet gebeurt. Dergel ijke besprekingen blijken erg Instrumenteel on oplelders via Informatle van collega's te leren, wat ze wel en nlet van cen student kunmen verwachten en op welke wljze zij zelf een rol kunnen spelen in het aanbieden van leermogel ljkheden aan de student.

5.3. Beoordelling van het student-patlentcontact.

5.3.1. Opzet van de beoordeling in de hulsartspraktijk.

Een van de aspecten, waaraan bll de opzet van het PMOH veel aandacht geschonken is, was de beoordeling van het student-patlënt-contact. zaols reeds eerder is ulteengezet, speelde een dergell wke beoordelling geen rol blj het memen vam besll issingen over de verdere studievoortgang van de student. Daardoor bleven twee andere doelstellingen over, namelljk het geven van informatle aan de student over de kwalltelt van $z$ ijn handelen (formatleve becordeling) en het verkrljgen van gegevens over de mate war in stagedoel stell ingen real I seerbaar bleken (programma-eval uatlel.

Achtereenvalgens zal aangegeven worden op welke wlyze getracht is vorm te geven an belde aspecten.

BInnen de planningisgroep werd de behoefte gevoeld an naast de Informele formatlewe beoordeling (de dagell lkse nabesprek ingen tussen hulsarts-opleider en student) ook an antal meer formele formatleve beoordelingen in de vorm van schrlftell Jke becordelling wan geobserveerde contacten te laten platsvinden. Over de wensellykheld on de hulsarts-opleider cok in een meer formele beoordelling een roll te laten spelen llepen de men ingen ulteen.

Twee bezwaren werden aangevoerd tegen het betrekken van de oplelders blj een dergelljke beoordel Ing. In de eerste plats werd het argument van de rolvermenglng gebrulkt: de oplelder werkt dagel ijks intenslef 
met de student samen: en dergolijke werkijze zou het ommogellik maken an wan oplelder te vragen op en meer af standelljke wljze het handelen van de student te beoordelen en vast te lleggen op schrift. Het tweede argunent betrof de kwalltelt van de becordelaars: in hooverre is het wensellJk am van hulsartsen, dle in de eerste plats op basis van bereldwilligheld en nlet op grond wan een krltische becordelling van hun kwallteiten als arts an dit stageprograma desl nemen to vragen en cordel over het handelen van studenten ult te spreken. Gezien het gegeven, dat het gaat om een formatieve beoordeling werd ultelindel l Jk besloten op experlmentele basis de opleliders bij de meer formele beoordelling te betrekken.

Dit principe dlende nu verder ultgewerkt te worden in een becordeI ingsmethode. Cekozen werd voor een opzet waarbij de hulsarts-opleller en consult van de student zou bijwonen en zljn cordeel zou invullen op een vragenlijst, waar in relewante beoordel ingsaspecten zijn opgenomen. Na af loop zou de oplelder dan een nabespreking met de student houden om op dle wijze cok meer informeel commentaar te kunnen geven. De student makt van zlln consult een Journaal volgens de gebrulke11. ke methode; dit Journaal wordt eveneens in de beoordelling betrokken.

Aangezien thet hier ging an een formatleve becordelling werd gekozen voor eon tweetal momenten in de stage, ma ongeveer vier en na acht weken stage, om deze gestructureerde observatle te laten pllatsvinden. Het eerste tijdstip werd met name zo gekozen dat verwacht mocht worden, dat student en oplelder al enigszins op elkar ingespeeld zouden zijn, zodat onwennigheld of bedreiging, dle een beoordel ingssituatle met zich mee kan brengen, minlmaal zouden zijn. Het tweede tijdstlp werd zodanig gekozen, dat studenten nog gelegenheid zouden hebben on tljidens de stage aan eventuele tekortkomingen te werken.

Ondanks de zorguuldige voorberelding en de zachte aandrang vanuit de planningsgroep bleek al snel dat de hulsarts-oplelders de voorgestelde broordel ingsiltuatlo in de praktljk moellljk to verwezenlljken achttan. De wersto beoordelling, dle in de zesde woek was gepland, vond in veel gevallen pas later plaats en in 5 praktijken in het geheel nilet. Na andrang door de hulsarts-begelelders, warblj ook het belang van dit Instrument voor het onderhavlge onder zoek in het geding werd gebracht, daalde het aantal $n$ llet ultgevoerde beoordellingen tot 3 . De anmerklngen van hulisarts-oplelders leldde ertoe, dat besloten werd in de tweede stageperlode slechts éen beoordeling te laten platswinden. In zes praktijken vond deze beoordeling inlet plaats. 
In de tussentljdse besprekingen met hulsarts-oplelders is getmentar Iseerd welke bezwaren er tegen de voorgestel de methode bestonden. Genoemd werden onder meer: 1 ljdgebrek, moeillijk to organlseren, moelIIIjke ruimtellijke amstandigheden, bezwar tegen "onnatuur IIjke" en afstandel ljke beordeling en tegenzin bij de student. Tijdens de besprekingen liet een aantal hulsarts-opleiders, die wel de formulieren hadden ingevuld, doorschemeren, dat ze nlet zozeer het consult, "naer meer hun algemene indruk van de student hadden weergegeven.

Op grond van de onvolledigheid wan het materlaal en de twljfel die gerezen is ten aanzlen van de waarde, dle aan wel Ingevullde formulleren zou magen worden gehecht, heeft de onderzooker ervan afgezien dit materiaal verder te bewerken.

5.3.2. De becordel Ing van het contact met simullatlepatlënten.

Naast deze twee gestructureerde observatles in de praktijk werd aan het elnd van de stage $\infty k$ een consult tussen de student en een simulatiepatient gepland in het skllislab. De reden hlervoor was, dat In een gesimuleerde situatle de student en volledig consult kan doen, Inclusief advles, theraple of verwljzing. Dit consult zou op videoband worden opgenomen en in earste instantie door de hulsarts-begelelder beoordeeld worden aan de hand van de eerder vermel de vragenllijst. Na af loop hlervan werd een nabespreking tussen de hulsarts-begelelder en de student gepland.

De videobanden bleden daarnaast en interessante mogel ijkheld consistentiles en inconsistentles in de beoordelling te onderzoeken. In de praktijksituaties varlëren immers tenminste drie varlabellen tegelljkertija, zonder dat een adequate contrôle mogellijk is, namelljk het aangeboden patlëntenprobleem, de wijze wan beoordelen door de becordelaar en de kwalitelt van het handelen van de student.

De videoconsulten in het skllislab ziljn daarentegen miln of meer gestandaardiseerd ten aanzien van het aangeboden probleem en door mlddel van becordeling door meerdere becordel aars kan men ook lets te weten komen over de wijze van becordelen.

Op grond van deze overweglingen zljn de videobanden na afloop van de stage cok nog eens door de huisarts-oplelder becordeeld met behulp van de vragenlijst. 
5.3.3. Het beoordeling sunstrument.

Ten behowe wan de obervatle van student-patiënt-contacten dlende esn beoordelingsinstrument ontwikkeld te worden. Dit beoordellngsinstrument dlent zodanig te zljin, dat het aspecten van het handelen wan de student beoordeelbar mabkt, ongeacht de aard wan het medisch probleem, warme de student gecontronteerd wordt.

Als ultgangspunt voor dit instrument werd en vragenlljst genomen, die door H.G. Schmldt ontwlkkeld werd ten behoeve van de becordelling van student-simulatiepatlënt-contacten in het $\$ k l l$ slab. Deze lljst sas gebaseerd op en antal, onder meer Amer lkaanse, voorbeelden van dergell jke beoordel lingsinstrumenten.

Niet gepubll lceerde pllotstudies met dit instrument hadden en bemoed igend resultaat: beoordelaars bleken in staat de vragen te beantwoorden en de conslstentle van de antwoorden was bevredigend.

ult deze llijst werden een aantal vragen verwijderd, dle te zeer bleken samen te hangen met de beoordelingssituatle in het Skillsiab, waar de student geacht wordt een woll ledlg consult te doen. Anderzljes werden een aantal uragen toegevoegid met betrekiking tot de kwalltelt van de verslagleggling door de student.

Op deze wijze ontstond een vragen lijst, bestaande uit 24 vragem. De gegevens, dle met behulp van deze vragenlljst verzamelld werden tijdens de beoordeling van vildeobanden door oplelders en begelelders werden door middel ven en factoranalyse iprinclpale companentenanalyse gevolgd door VARIMAX-rotatie) verder bewerkt am na te gaan welke dimensies in de becordelling onderschelden kunnen worden en on een verfljning van het instrument mogell $J k$ te maken.

Eén vraag werd voor de analyse reeds geschrapt uit de vragenlijst, aangezlen mlerblj door en cantal beoordelars werd vermeld, dat deze viratag nlet beantwoordboar was en angezlen deze vraag Inderdaad waak nlet Ingevuld werd. Melt behulp van het SPSS factoranalyse-programma werden 88 beoordel lingen van student-simulatlepatient-contacten in het SkIII I lab geanal yseerd. Na VARIMAX-rotatle ontstond oen goed interpreteerbare drle fictoroplossing. Drie vragen ult de viagenlljst ble-

* 1 student nam door zlekte niet deel aan de beoordeling, 1 video-opname bleek mislukt en twee hulsarts-oplelders wareri niet in staat medewerking aan de scorling te verlenen. Voor 4 studenten waren becordelingen door twee begelelders beschlkbaar, andat een van de begellders zlch tijdens het becordel ingsgesprek liet vervangen en achteraf alsinog de videobanden beoordeelde. 
ken geen lading van enlge betekenis te hebben op en van deze factoren (minder dan .40 ) en werden op grond hlervan ult de vragenllyst verwljderd.

De gereduceerde uragenlljst werd nu opnleum onderworpen an een factoranalyse, warbll na VARIMAX-rotatio opnleuw dr le factoren ontstomden, die wrlJwel overeenkwamen met de in de oerste analyse gevonden factoren. De 3 factoren verklaren samen $68 \%$ van de varllantle. De rom latleve bljarage van de 3 factoren aan werklaarde varlantle bedraagt respectievellJk $82 \%, 12 \%$ en $6 \%$.

In tabel 5-8 zlJn de factoren met de bljbehorende ladingen weergegoven. Als crlterlum voor opname wan sen wrag blj en bepaalde factor is steeds. 40 of hoger aangehouden.

Vler vragen bieken op grond daarvan blj te dragen aan twee factoren. Men zou de factoren als volgt kunnen benoemen:

Factor 1: competent medisch handelen.

op deze factor laden vragen, die verwljzen naar een goede en mothodische aanpak door de student, zowel in de anamnese, het onderzoek, als in de verslaglegging.

Tien vragen lever a deze factor en bljdrage.

Factor 11: kwallteit van het student-patlënt-contact.

op deze factor laden vragen, die verwijzen naar het ongaan van de student met de patlënt.

Actht vragen leveren en bljidrage aan deze factor.

Factor 111: Onderzoeksvaardligheld.

Deze factor onvat alle vragen met betrekking tot de uitvoering van het lichamelljk onderzoek. Daarnaast blljkt cok de vraag met betrekking tot het professioneel gedrag van de student hler een bljdrage te leveren. Gezien thet felt clat 3 vam de 5 viragen ook en bljdrage leveren aan de eorste twee factoren, is er sprake van een duldelljke overlap tussen deze factor en de eerste twee factoren.

op baslls ven de ulitkomsten van deze factoranalyse is het mogellik de scores wan de studenten op de afzonderlljke vragen samen te voegen in sen drletal scores. Uitgaande van het standpunt, dat oen dergel ljke berekening enwoudlig in de dagelljkse praktljk mogelljk moet $2 / \mathrm{Jn}$, is In de verdere rapportage gekozen voor en simpelle optellilling van de ruwe scores op de vragen, in plaats van de moer olegante berekenling wan factor scores. 
Tabel 5-8: factoren en factorladingen van het beoordel ingsinstrument van het student-patient-contact.

Fuctor 1

$$
\text { "Competent medisch handelen" }
$$

$\frac{\text { factor }}{\text { lading }}$

Var. 4: HIJ zorgde ervoor dat het gesprek soepel en efflclënt verlilep hileld het gesprek in de hand wanner dat nodig was.

Var. 10: Hij verzamelde al le felten dle noodzakelljk zljn on tot goede diagnose te komen.

Var. 11: HiJ gebrulkte voldoende de relevante ter beschlkkling staandle gegevens ult de medlsche voorgeschledenis.

Var. 13: HIJ probeerde alternatleve dlagnoses uit te sluitan.

Var. 14: ZIJn wlJze van vragen stellien vertoonde cen duidell jk methodlsch patroon.

Var. 15: Bij het stellen van vragen maakte hlj goed gebrulk van eerdere antwoorden van de patiënt.

Var. 18: Het I lchamelljk onder zook was goed georgan iseerd en efficlënt*

Var. 21: De verslaglegging bevat de relevante anamnestl sche gegevens.

Var. 22: De verslaglegging bevat de relevante gegevens ult het llchamel IJk onderzook.

Var. 24: Alternatleve dlagnosen worden duldelllk ultges loten. 
Factor 11

Var. 1: De student stelde zlch op een professlonele en vrlendelljke wljze voor an de patient.

Var. 2: Hij gebrulkte woorden die voor de patient begrljpellikk waren.

Var. 3: HilJ lulsterde geinteresseerd naar de patlënt. .70

Var. 4: Hj zorgde erwoor dat het gesprek soepel en efflclènt verlliep en thleld het gesprek in de hand wanneer dat nodig was.

Var. 5: Hij toonde zich bewust van gevoelens van de kant wan de patlënt.

Var. 7: Hij moedlgide de patiënt aar on vrlj en openhartig te praten.

Var. 8: Hij stelde de patient op z'n gemak.

Var. 9: De student maakte een open Indruk.

Factor 111

"Onder zoeks vaardigheid"

Var. 1: De student stelde zlch op een professlonele en vrlendelijke wijze voor aan de patlënt.

Var. 18: Het lichamelljk onder zoek as goed georgan lseerd en ficlent.

Var. 19: Het Ilchamelljk onderzoek werd zorgwuldig gedeon.

Var. 20: Alle activitelter dle de arts ultwoerde in het kader van het 1 lchamel lJk onderzoek waren zinvol in het I icht van mogelljke dlagnose.

Var. 22: De versilaglegging bewat de relevante gegevons uit het I ichamel lijk onder zoek. 
Naast de interpreteerbaarheld wan de vragenlijst speelt ook de bo troubaarheld war de beoordelling en rol. Aangezien er 5 varschillende huisarts-begelelders en verschlllende hulsarts-opleiders oen oordeel hebben ultgesproken is een schatting van de conslstentle van het cordeel op basls wan correlatleonderzoek niet mogell I k..

Daarom is gekozen voor ben benaderling, waerbij is nagegaan in hoewel procent van de gevallen oplelder en begelelder tot en vergelljkbaar cordeel kwamen. Als ultgangspunt voor de berekening is genomen de gemiddelde score wan de student op en factor, dit is de ruwe score, gedeeld door het aantal wragen dat een bljdrage levert aan dle factor. Deze score kan dus variëren van 5 (Is zeer goed) tot en met 1 (zeer slechty. Wanneer begelelder en opleider minder dan 1 punt op deze schaal van ell har werschlllen in hun cordeel wordt dit een redelljke overeensteming genoemd, tussen 1 en 2 punten verschll wordt beschouwd als onvoldoende overeensteming en blJ meer dan twee punten wordt dit beschouwd als sllechte owereensteming.

In tabel 5-9 z Ijn de overenstemingscijfers gepresenteerd. De resultaten zljn, gezlen het fellt dat het om zoveel verschilliende becordelaars gaat, bevredigend te noemen. Anderzijds kan worden geconcludeerd dat dergelljke cordelen te sterk van elkaar afwljken on een besllssingsgerlcht cordeel over de kwallteiten van individwele studenten mogel $\| j k$ to maken.

Tabel 5-9: Overeensterming tussen hulsartsoplelder en hulsarts-begelelder in beoordeling.

De gegevens zijn gebaseerd op 41 beoordeel de studenten.

overeansteming
factor redell Jk onvoldoende slecht

I competentile

11 contact 
Een verrassende uitkonst is zeker dat de overeenstening op factor 11 , de kwaliteit van het student-patient-contact het grootst is. Men zou eerder verwachten dat een beoordel ing van meer medlsche aspecten tot grotere owereensteming zou $\|$ elden.

5.3.4. Beoordellingsresultaten van de student-simulatiepatient-contacten.

De onderstaande resultaten hebben betrekking op de scores van 41 studenten, waarvan zowell een beoordeling door de huisarts-oplelder als door de elgen huisarts-begeleider beschikbaar was.

Het presenteren van deze resultaten geeft op zlch geen dlrecte informatlie over de mate war in het stageprogramma geslaagd genoend kan worden. Positlleve en negatleve uitkomsten kunnen echter well gebrulkt worden an de prloritelten, die in de stageopzet gekozen zijn aan te scherpen of te willzigen.

Aangezlen de beoordelingen gegeven zljn op 5-puntsschalen, waarbll 5 zeer goed en 1 zeer slecht betekent, kan men nagaan in hoeverre studenten als voldoende of onvoldoende beschouwd worden door de huisarts-opleiders en de hulsarts-begelelders.

Allereerst zal worden Ingegaan op de resultaten voor de tatale groep studenten. In tabel 5-10 zljn deze gegevens gepresenteerd.

Uit deze gegevens bll jkt, dat zowel de hullsarts-begeleiders als de oplelders gemiddeld een positlef oordeel over het handelen van de studenten hebben aan het elnd van de stage. Opvallend daarblj is dat de hulsarts-opleiders over het algemeen "strenger" oordelen over de studenten dan de huisarts-begelelders. Tljidens de stage bestond bij de planningsgroep de Indruk, dat opleliders genelgd waren tekortkomingen wan studenten te relativeren. Wellicht dat de context wan de beoordelling, namelljk het na afloop van de stage beoordelen van en videoband, een werklaring vormt voor het gegeven, dat julst de opleiders een strenger oordeel ultspreken. 
Tabel 5-10: Resultatenbeoordel Ing student-simulat lepetient-contact door hulsarts-begelelders on hulsarts-oplelders.

\section{Factor I competentle}

$\begin{array}{ll}\text { hulsarts-begeleider } \quad & m=4.0 \\ & s=.85 \\ \text { hulsarts-opleider } & m=3.6 \\ & s=.73\end{array}$

Fector 11 contact

hulsarts-begelelder $\quad \begin{aligned} m & =4.1 \\ & s=.73\end{aligned}$

hulsarts-opleider $\quad m=4.0$

$s=.76$

Factor 111 vaordigheld

$\begin{array}{ll}\text { hulsarts-begelelder } & m=4.0 \\ & s=.90 \\ \text { hulsarts-oplelder } & m=3.7 \\ & s=.90\end{array}$

(beoordell Ingen op een 5-puntsschaal waarblj $5=$ zeer goed)

Gemlddel de resultaten, zools hler gepresenteerd, geven onvoldoende inzlcht in de vraag in hoeverre de tevredenheld zllch uitstrekt over individuele studenten. Yandaar dat in tabel 5-11 voor ledere factor staat aangegeven welk percentage studenten door hulsarts-begelelder of hulsarts-oplelder onvoldoende scoorden, dat wil zeggen genlddelde score lager dan 3 behalden. Afzonderlijk is vermeld welk percentage studenten doar belde beoordelaars als onvoldoende werd beschouwd. 
Tabel 5-11: Percentage onvoldoende beoordelling door hulsarts-begellelder en hulsarts-opleider.

$\begin{array}{lll}\text { huisarts- } & \text { hulsarts- } & \text { beldo beoor- } \\ \text { begelellder } & \text { oplelder } & \text { delars }\end{array}$

$\begin{array}{lrrr}\text { factor I competentle } & 20 \% & 24 \% & 7 \% \\ \text { factor } 11 \text { contact } & 7 \% & 12 \% & 5 \% \\ \text { factor } 111 \text { vardigheld } & 15 \% & 22 \% & 5 \%\end{array}$

Uit deze gegevens blljkt dat met name op het gebled van de competentie en de onder zoeksvaardlgheden door tenmilnste één van de twee beoordelaars nogal wat onvoldoende beoardelingen werden gegeven. Legt men die beoordellingen naast elkaar, dan kan men echter evenzeer concluderen, dat slechts enkele studenten door bellde beoordelaars op deze twe factoren alls onvoldoende werden gescoord.

Samenvattend zou men kunnen stellen dat een ger ing percentage studenten aan het elnd van de stage duldelljk als onvoldoende competent en/of beschlkkend over onvoldoende vaardlgheden wordt beschoumd en dat over en wat grotere groep twijfels op dit punt bestaan. De conclusles ten aanzien van de kwallitelt wan het student-patient-contact zijn, zoals mocht worden verwacht op basis van de grotere overeenstemming tussen beoordelaars, eenduidlger: slechts een gering percentage studenten wordt als onvoldoende beschould.

Door verdere uitsplitsing van de beoordelingsgegevens is het mogel Ijk de vraag te beantwoorden in hoeverre ver verschll lan in beoordeling zllyn tussen de eerste stagegroep en de tweede stagegroep. In tabel 5-12 z lju de resultaten voor de eerste en tweede stagegroep aizonder l IJk vermeld. De verschillen zljn tweezlj dig getoetst met de t-toets. De trend in de gegevens is duldelljk: de tweede stagegroep scoort altijd hager dan de eerste stagegroep. Deze trend bliljkt echter alleen signiflcant voor de becordel ingen door de hullsarts-begellelder. Over de corzakk van dit verschll in beoordelaarsgedrag walt geen deflnltleve ulltspraak te doen: enerzljjs kan men beargumenteren dat de door de hulisarts-beglelelders geconstateerde versch\|llen reëel zlJn, ondat zil in de gelegenheid waren studenten in belde perloden te be- 
oordelen; ander zljds kunnen de hoge scores voor de tweede stagegroep mogell Jk het gevolg zlJn van een self-fulfllling prophecy: de tweede stagegroep zal beter zijn, aangezlen ze meer ervarling heeft. Voor de huisarts-opleiders gelden deze overwegingen echter nauwellijks: het grootste deel van de oplelders beoordeelde maar éen student en bezat derhalve geen duldelljk referentlekader.

Tabel 5-12: Becordelingsresultaten voor de eerste en tweede stagegroep.

\begin{tabular}{|c|c|c|c|}
\hline \multirow{3}{*}{ becordellar } & \multicolumn{2}{|c|}{ Factor 1 competentie } & \multirow[b]{2}{*}{ t-toets } \\
\hline & groep 1 & groep 2 & \\
\hline & $(n=22)$ & $(n=19)$ & significantle \\
\hline hul sarts- & $m=3.6$ & $m=4.5$ & .01 \\
\hline begelelder & $s=.83$ & $s=.63$ & \\
\hline hulsarts- & $\mathrm{m}=3.5$ & $m=3.7$ & n.s. \\
\hline opleilder & $s=.76$ & $s=.72$ & \\
\hline
\end{tabular}

Factor 11 arts-patlënt-contact

$\begin{array}{llll}\text { hulsarts- } & m=3.8 & m=4.3 & .05 \\ \text { begelelder } & s=.73 & s=.68 & \\ \text { huisarts- } & m=3.9 & m=4.2 & \mathrm{n} . \mathrm{s} . \\ \text { opleider } & s=.84 & s=.67 & \end{array}$

Factor 111 onder zoekswardigheld
hulsarts-
$m=3.7$
$m=4.4$
.01
begel l der
$s=1.0$
s. $=.59$
hul sarts-
$\mathrm{m}=3.5$
$m=4.0$
n.s.
oplelder
$s=1.0$
$s=.68$

(becordelingen op een 5-puntsschaal, 5 = zeer goed). 
5.4. Conclusies.

Concluderend kan gesteld worden dat studenten gedurende hun stage in de hulsartspraktijk in de gelegenheld zijn on en ruim aantal vaardigheden in de praktijk to to passen. Ult de zelfoordelen van studenten b ll jkt, dat het beheersingsn I veau gem Iddell genomen toeneemt tijdens de stage. Aan het elnde van de stage blijkt het cordeel van de opleiders over het algenene vaardigheldsniveau overwegend positlef te $2 \mathrm{lj} n$. Wel is duidelljk, dat studenten, die reeds en stage van zes maenden In de klinlek achter de rug hebben, méer vaardligheden toepassen tIJdens de PMOH-stage en over het geheel genomen ook positiever worden beoordeeld aan het elnde van de stage.

Het aanvangsnlveau van studenten, dle aan het begin van het vijfde studlejar in het PMOH starten, beantwoordt nlet aan de verwachtingen van de plannlngsgraep. Niettemin kan ult de resultaten worden afgeleid, dat actieve participatie in de hulsartspraktljk ook voor deze studenten mogel ijk is. 


\section{Hoofdstuk 6 \\ Attitude en attitudeveranderingen in het $\mathrm{PMOH}$}

6.1. Inlelding.

De explliclete andacht dle arn het onderwerp attltudevorming in medlsche opleidingsprograma's geschonken wordt kan in belangrljke mate toruggevoerd wordem op een aantal publlicatlies ult de vifftiger Jaren, warult bleek, dat de medlsche opleiding ean a antal negatleve effecten op de attltuden van medische studenten heeft. De onderzoek Ingen van Eron (1955, 1958) toonden aan, dat medische studenten in de loop van hun medische studie en cynlsche attitude ontwlkkelden. Deze ontwlkkeI ling kon moellijk aan "rlJpl'ng" of a an een algemene trend worden toegeschreven, aangezlen onderzaek onder studenten in andere studlerlchtingen Juist het tegendeel te zlen gaven. Deze geruchtmakende studles werden gevolgo door en stroom andere, war in overeenkomstige resultaten gemeld werden met als ultschleters onder zoek war in geen verandering gedurende de oplelling werd gevonden. Voor een beknopte samenvatting van deze onder zoekingen kan worden werwezen naar Rezler (1974) on Gerr Itsma Smal (1974). De veronderstelling, dat deze ontwlkikeling een reactle van studenten is op hun (negatleve) ervar Ingen in hun opleidingsituatie en niet een reactie op de geneeskunde als beroepskeuze, werd onderzocht door Relnhardt \& Gray (1972). ZlJ vergeleken cynlsme scores van vergelljkbare groepen afgestudeerden die kozen voor ean "high interaction" speclallsme (in de Nederlandse sltuatle enlgszins vergelljkbaar net en carrlère in de eerstelijnsgezondheldszorg) met afgestudeerden, dle kozen voor een "low interaction" speclal isme. Na vier Jaar bloek dat de afgestudeerden In de "hlgher interactlon" speciallsmen en significant lagere cynlsme score hadden dan hun collega"s in een "low Interaction" speclallisme, hoewel hun scores aan het - Ind van hun oplelding nlet ven alkaar werschilden. De auteurs concluderen ult deze gegevens, dat de ongeving warlin geleerd en gewerkt wordt de at+1tude van artsen en studenten beinvloedt.

De negatleve invloed van medische opleldingen op de ontwikkeling van relevante attituden bld medlsche studenten bllj ft zeker nlet beperkt 
tot opleldingen in de Verenlgde Staten. Onderzoek van Gerrltsma \& Relltsma (1973) wlJst in dezel fde rlichting. Dabrmast kan varwazen worden naar recenter onderzook, warin de negatleve ervarlingen die studenten in het medisch onderw IJs opdoen centraal staan (Bender, "1979), en nar beschrijuingen van die ervaringen door studenten (de Vrlles, 1979; van Es, 1979).

Gezien de zoluist sanengevatte voorgeschledenls is het inlet vreend; dat in de Basisfllosofle van de facultelt der geneeskunde in Maastrlcht als andachtspunt genoemd wordt de ontwlkkeling wan attltuden, dle van belang zijn on is "goed" arts te functloneren.

Het blijkkt echter moellijk te $z i j n$ on nauwkeurlg te cmschr ljvem waarult dle attluden die men poogt te bevorderen nu eligenlljk precles bestaan en op welke wljze men studenten zou kunnen helpen die attlltuden te ontwkellen.

Schmldt en van Loon (1976) hebben kort na de start van het onderwiJs In de facultelt der geneeskunde in Maastrlicht getracht "attitudeontwkkeling" nader to anschrlJven. ZlJ constateren dat de verwarring over dit onderwerp te maken heeft met een drletal miswerstanden:

1. De gedachte dat en facultelt attituden zou noeten aanbrengen die er nog intet zljn. Een noodzakelljke correctle op dit punt is de omschrljuing dat attitudeontwikkelling gerlcht is op de nuancering of verander Ing van bestaande attltuden.

2. De gedachte dat attlituden zlch nlet zouden ontwikkelen, wanneer er geen expliclete aandacht in het onderwlJs aan besteed zou worden. De schrljvers ifzen erop dat impliclet in het onderwiJsprograma attltuden genuanceerd en veranderd zullen worden door kennls, contacten met studenten, dacenten en patlënten. Het voorkomen van ongewenste attituden in het onderwlJs zou daarom een bellangrlJk aspect van de taak van en facultelt dienen te zljn.

3. At+ltude wordt vaak als synonlem wan "grondhoudling" gebrulkt. Daardoor wordt het extra moelllJk anknoplngspunten voor verandoring te vinden. De schrlljvers stellen dat in het medisch onderwijs de attltuden van studenten ten opzichte van een viertal categorleän relevant zIJn: de attitude ten opzichte van het onderwijs, de beroepsultoefening, de elgen persoon en de maatschapplil. In tabel 6-1 zljn een aantal voorbelden blnnen leder van deze gebleden overgenomen. 
Tabel 6-1: Relevante attitudegebleden in het medisch onderwijs (Schmidt \& van Loon, 1976).

\begin{tabular}{|c|c|c|c|}
\hline $\begin{array}{l}\text { 1. De Med ische } \\
\text { Facult telt }\end{array}$ & $\begin{array}{l}\text { 2. Beroepsultoefe- } \\
\text { nlng }\end{array}$ & 3. Jezelf & 4. Mastschapp IJ \\
\hline $\begin{array}{l}\text { at+l tudes two.v. } \\
\text { - de aard van het } \\
\text { onderwils } \\
\text { - het samenwer- } \\
\text { ken in taak- } \\
\text { grcepen, } \\
\text { - docenten, } \\
\text { - medestudenten, } \\
\text { etc. }\end{array}$ & $\begin{array}{l}\text { attitudes two.v. } \\
\text { - de gezondheids- } \\
\text { zarg, } \\
\text { - collega's, } \\
\text { - Je elgen rol als } \\
\text { arts, } \\
\text { - patlếnten, } \\
\text { - zlekte, } \\
\text { - paramed Isch per- } \\
\text { soneel, } \\
\text { - hete hang IJzers } \\
\text { In de gezondhelds- } \\
\text { zorg, } \\
\text { - etc. }\end{array}$ & $\begin{array}{l}\text { attl tudes } t \text {.o.v. } \\
\text { - Je elgen func- } \\
\text { tloneren ln } \\
\text { relatie tot } \\
\text { andere mensen, } \\
\text { - je vroegere } \\
\text { levenserva- } \\
\text { ringen, } \\
\text { - je elgen belle- } \\
\text { ving van prak- } \\
\text { tljkervar lingen, } \\
\text { etc. }\end{array}$ & $\begin{array}{l}\text { attltudes t.o.v. } \\
\text { - de poll liek, } \\
\text { - de socl laul- } \\
\text { economische } \\
\text { verhoudingen, } \\
\text { - de cul tuur, } \\
\text { - etc. }\end{array}$ \\
\hline
\end{tabular}

In de stage PMOH wordt de ontwikkeling van attituden als van de doelstellingen beschouwd. Wanneer we naar de indelling van Schmidt \& van Loon klJken, dan IIJken met name de gebleden "bercopsultoefenIng" en "de elgen persoon" relevant.

Zel fs binnen deze categor leën is het onmogelijk in het kader van een onderzoek, dat zlch nast de ontwikkeling van ottituden ook rleht op andere effecten van stageprograma, onder zoeksopzet te realiseren, warlin alle relevante attituden worden onderzocht. In dit onder zook is getracht no to gaan welke Invloed de stage in de hulsartspraktijk heeft op de attifuden van studenten ten anzlen van de artspatlänt-relat le, met name in de oerstelljnsgezondheldszorg.

In de literatuur met betrekking tot attltudeontwlkkeling in het medisch onderwlJs (Gerrltsma \& Smal, 1974) wordt op het belang van prak+ Jjkervaringen van studenten in de gezondheldszorg gewezen blj de ontwikkeling van attituden op dit gebled. Relovante ervaringen die cen bljarage kunnen leveren 2 IJn het "gan den IIJve" ondervinden wat het artsenbercop inhoudt, controntatle met verwachtingen van patlënten ten aenzlén van arts, het in de praktijk brengen van theoretische in- 
zlchten. Voorts zlet de student in de praktijk andere artsen aan het werk; hij zlet hoe patlënten behandeld worden en hij kan in gesprekken met artsen ervaren hoe artsen tegen hum patiënten aankljken.

Tiegenover deze mogelljk positleve Invloeden op de ontwlkkeling van attituden staan echter cok magell ljk negatleve punten:

Men kan zich de vraag stellen of bljvoorbeeld de tljdsdruk, waronder artsen veellal werken niet leldt tot een vorm van zorgverlenling, die nlet ideaal is als angeving an een positleve attitude te vormen. In algemene zin kan men zlch voorts afvragen of de dagel ljkse praktijk van veel beroepen niet to ver verwljderd is van ldealen, die in universitalire oplelding als belangrijk worden gezlen.

op grond van deze overwegingen is het alleszlns de noelte ward te onder zooken of en in welke richting attlituden van medische studenten veranderen gedurende en stage in de hulsartsprakttljk.

Een andere vraag, dle evenzeer van belang is, is de vraag in hooverre studenten blj de aanvang van de stage beschlkken over attltude ten opzlchte van de beroepsultoefening en de patient on en stage, zoals dle hler ontwlkkeld is, optimaal te kunnen volgen.

Bil het onderzoek naar attitude en attitudeverandering is gebrullk gemakt van twee onderzoeks instrumenten:

1. Het zell foordeel van studenten on oplelders ten anzlen van relovante aspecten van de arts-patilënt-relatle, gemeten met de Maastrichtse Hulsartsenvragenllist (wan Loon, 1976; van Loon \& Schm Idt, 1977).

2. Het cordeel van oplelders over het functioneren van studenten in relatie tot patlënten. Hlerbij werd gebrulk gemaakt van de programaeval uatlevragen lifst.

6.2. De Mastrichtse Hulsartsenwragenlijst.

On de attltude en attltudeverander Ing ten opzlchte van aspecten van het hulsarts-zijn to meten, werd In het onderzoek gebrulk gemakt van de Masstrlchtse Hulsartsenvragenll ijst. Olt is een attlltudeschal bestaande ult twee parallelversles die leder 23 Items bevatten. De respondent dlent ten aanzlen van ledere ultspraak op 5-puntsschaal aan te geven in hoeverre hy het met deze ultsprak eens is. De 
Mastrlchtse Hulswtseriwragenlljst is voortgekomen uit een onderzoek naar relevante dlmenslles van de arts-patiënt-relatle. Im dat onderzoek (van Loon, 1976; wan Loon \& Schmldt, 1977) werden ultspraken, dle botrekking hadden op llerlel aspecten van de arts-patlient-rellatle voorgelegd aan 359 respondenten (medische studenten, psychologle-studenten on artsenl. De resultaten werden onderworpen aan een factoranallyse en er werd gecontroleerd of de betrokken proefgroepen systematlsch van elkar afweken. (Dit laatste bleek nlet het geval te zlJn). De factoranal yse resulteer de in dr le interpreteerbare, van elkaar onathankel IJke dimensles. Deze dimensles bleken goed overeen te stemmen met eerdere onderzooksresultaten (Katz, 1969; Cassee, 1973). De auteurs onschrijuen deze factorion als valgt:

1. De informatlefactor.

In hooverre acht ean arts het noodzakelljk cm patilinten to informeren over hum toestand, de ard ven hun problemen, de voorgoschreven medlciljnen, etc.?

11. De psycho-sociale factor.

In hoeverre erkent de arts dat er zolets als typllsche pyschosoclale problematlek bestaat? in hoeverre is hly bereid hlerop te reageren?

III. De beschlkbarheldsfactor.

In hoverre is een arts van mening dat artsen voortalurend berelkbaar moeten zijn voor hun patlënten?

In tabel 6-2 z IJ m een aantal voorbeelden gegeven van blj deze factoren behorende Items.

Op basls van dit onderzoek is de attitudeschas geconstrueerd, dle dus bestat ult arle subschalen, dle verondersteld worden de vilsle van de arts op deze drlo fundamentele dimensles van de arts-patleant-relatle to meten. Een aantal statlstische gegevens met bettrekking tot de schalen ziju vinden in tabel 6-3.

In die tabel zljn ook de geniddellde scores vermeld van de 359 respondenten utt het hlervoor vermelde onderzoek. De scores op de subschalen kunnen varlëren van 1 tot 5 . Een hoge score geeft aan dat men bereld: Is Informatle te geven, andacht to schenken aan psycho-socilale problematlek of blj nacht en ontlj beschlkbar te zijn. 
Tabel 6-2: Voorbeelden van Itens ult de Maastrichtse Hul sartsenvragenlijst.

Factor 1: Informatlie

33.

Het is voor vel ernstlg zleke mensen beter on door hun hulsarts nlet valledig op de hoogte gesteld te worden ven de ard van hun zlekte.

54. Daar een arts vaak nlet heet ho de informatie die hlJ een patlënt zelf geeft, verwerkt wordt, kan hij dle lnformatle beter zo beperkt magelljk houden.

Factor 11: Psycho-soclale hulp

1. Als hulsarts probert huwelijksproblemen van pen patlënt op te lossen, gaat hlj bulten zljn boekje.

50. Gezien de psychische aard van veel klachten warmee patlënten blj hun hulsarts komen, dient deze zlch cok op dit terrein to bekwamen.

Factor 111: Beschikbaarheld

11.

Een hulsarts zou patlïnten meer mogel IJkheden moeten geven om op een afspraak bulten de spreekuren bu hem langs to kanen.

48. Met een afsprakenspreekuur is een hulsarts voldoende berelkbaar voor zijn patlënten.

Tabell 6-3: Statistische gegevens van de Mastrlchtse HulsartsenvragenIljst (van Loon \& Sehmldt, 1977).

factor al fabetrouwbarheid aantal gem Iddel de

factor

0.87 10 3.6

1. Informatle

0.87

10

4.1

11. psycho-saclaal

0.71

3

3.3 
6.3. Vraagstelling.

Een or letal wragen kamt in dit onderzoek an de orde:

1. Verandert de attludude van medische studenten ten opzlchte van paHënten tludens do maenden praktlsch medisch onderzoek in de hulsartspraktljk?

2. Hoe verhoudt de attltude van studenten zlch ten opzlchte van de attitude van hulsertsen?

3. Is er en rellatie tussen de attitude en attltudeverandering van studenten en do attitude van hum hulsarts-oplleliders?

Tenelnde gegevens ter beantwoording van deze vragen te verkrljgen werd de Maastrlchtse Hulsartsenvragenllist aan het begin en an het ellind van de stage voorgelegd aan de studenten van de twee stagegroepen. Tevens vulden alle hulsarts-oplelders, dle als stagelelder fungeerden, belde versles van de attitudevragen IIJsten in. Drle hulsarts-opllelders bleken echter de twe male nlet bereld de vragenlijst of en deell darvan lin te vullien.

De waag of de ettltude van studenten tlljens hun hul sartsstage verandert, kan worden beantwoord door de verschllllen tussen begin- en elndmetling van de scoros op de drla factoren te toetsen met behulp van en t-toets voor gepararde warnem Ingen (tweezlj dig).

Een vergelljking van de begin- en elndscores van de hulsarts-oplelders kan beschouwd worden als een comtrôle op de parallelltelt wan de attitudeschalen. Men mag Immers veronderstellen dat de opvattingen van hulsartsen over de arts-patlënt-relatle zlch nlet aenzlenl IJk wijzlgen b. Innen enkele maanden.

De vraeg ten aanzllen ven de verhouding tussen de scores van studenten en hulsartsen kan worden beantwoord door met een t-toets de verschlllIon te toetsen tussen de scores van studenten op de drile factoren en dle van de hulsarts-oplelders. Do bagln- en alndmetingscores van de studenten worden gotoetst tegen de gemlddelde score van de hulsartsen op de belde parallelverstes van de vragenlljst. Zoals eorder vermeld hebben 3 hulsartsen de tweede versie van de vragenllJst nlet ingevuld. voor de ontbrekende gegevens wordt het resultat van de eerste metling in plaats van het gemiddelde gebrulkt.

De derde vraeg heeft betrekking op een mogellike beinvloeding van de 
opvattingen wan de student door zljn oplelder. Deze wrasg kan beantwoord worden door allereerst na te gaan of or aan het ellnd van de stage signiflcante correlatle bestad tussen de opvattingen wan de hulsarts-oplelder en van de student. Voorts zil echter vastgesteld moeten worden of deze correlatle an het elnd van de stage hoger is dan aun het begin. Indlen dat het geval is kan men asnnemen dat de opvattingen van de hulsarts-opleider van invloed zijn op die van de student.

6.4. Resultaten met betrekking tot de Maastrlchtse HulsartsenvragenIIIst.

De relevante gegevens met betrakking tot de in de vorlge paragraaf gonoemde erste vraagstelling ziljn gepresenterd in de tabellem 6-4, $6-5,6-6$.

Op de gevonden gemiddeldem is, war zinvol, ven varlantle-analyse ultgevoerd (herhaal de metlingen, ongewogen gemlddel de methode als correctie voor ongelljke aantallen (winer, 1971)).

Uit de resultaten ten aanzlen van factor 1 , het verschaffen van informatle (tabel 6-4), bl ljkt, dat sprake is ven signiflcanto verandering in attltude tussen het begin en het elnde van de stage. Aangezien cok sen significante interactle gevonden wordt is volgens de methode van "simple main effects" (Winer, 1971) nagegaan welke gemlddelden onderling van elkaar verschillen. Uit deze nadere analyse blijkt, dat bij de eerste stagegroep een signiflcante verandering van attitude plaatsvindt $(p<.01)$ dat deze daling minder duldelljk is bij de tweede stagegroep $(p<.10)$ en dat an het einde van de stage de tweede stagegroep significant hoger scoort dan de eerste stagegroep $(p<.05)$.

Studenten gever aan dat zlJ aan het el nde wan hun stage minder genelgd zijn de patiënt informatle te geven.

De gemiddelde scores op factor 11 , aandacht voor psycho-soclale problematlek (tabel 6-5) zijn vergelljkbaar voor belde stagegroepen on veranderen nlet gedurende de stages.

De resultaten met betrekking tot factor 111 , de beschikbaarheld (tabel 6-6), geven aan dat geen significante verschill len tussen belde stagegroepen optreden. Wel blljken studenten aan het olnde van hum stage het beschlkbar zljn voor patlënten minder belangrljk te vinden dan aan het begilin. 
Tabe 1 6-4: Resultaten factor 1.

$$
\text { bugin elnd }
$$

groep :

$\begin{array}{ccc}m & 3.8 & 3.2 \\ 5 & .43 & .46\end{array}$

groep $\|$

$\begin{array}{lll}m & 3.7 & 3.5 \\ 5 & .30 & .35\end{array}$

tussen personen

stagegroep

personen bilnnen groepen

$\begin{array}{lrlrl}\text { SS } & \text { OF } & \text { MS } & F & P \\ .2204 & 1 & .22 & <1 & \text { n.s. } \\ 10.765 & 43 & .2503 & & \end{array}$

bInnen groepen

attltudeverander Ing

attlltude $x$ groep

$\begin{array}{rrrrr}3.584 & 1 & 3.584 & 26.28 & .01 \\ .896 & 1 & .896 & 6.57 & .05 \\ & & & & \\ 5.865 & 43 & .1364 & & \end{array}$

Tabel 6-5: Resultaten factor II

$$
\text { begin elnd }
$$

groop

$\begin{array}{llc}m & 4.1 & 4.1 \\ \mathrm{~s} & .50 & .42\end{array}$

groep II
m
4.2
4.2
$s$
.41
.30

De gerlinge verschillen maken toetsing overbodig. 
Tobel 6-6: Resultaten factor 111

$$
\text { begin elnd }
$$

groep 1
m
3.0
2.9
$\mathbf{S}$
.50
.50

groep 11

$\begin{array}{lcc}m & 3.1 & 2.7 \\ \mathrm{~s} & .59 & .65\end{array}$

tussen personen

stagegroep

$\begin{array}{lrlll}\text { SS } & \text { DF } & \text { MS } & F & P \\ .224 & 1 & .224 & 1.76 & \text { n.s. } \\ 5.48 & 43 & .127 & & \end{array}$

personen binnen groepen

binnen groepen

attlitudever ander ing

attitude $\times$ groep

$\begin{array}{rrrrr}1.569 & 1 & 1.568 & 5.79 & .05 \\ .224 & 1 & .224 & & \text { n.s. }\end{array}$

attitude $x$ personen binnen

groepen

11.67

43

.271

De tweede vraagstelling betreft een vergelljklng tussen de attltuden van studenten en hulsarts-oplelders. De scores van de studenten zljn hier vergeleken met de gepoolde resultaten van de hulserts-oplelders op belde metingen.

In tabel 6-7 zljn de resultaten van de hulsarts-oplelders per factor vermelld. De gemiddelde scores op belde parallelversles van de vragenlijst stemmen zeer goed met el kaar overeen, zodet de oerder gevonden verschillen tussen begin- en eindscores van studenten nlet aan constructlegebreken in de vragen lijst kunnen worden toegeschreven. In tabel 6-8 zijm voor ledere stagegroep de begin- en elndscores getoetst tegen de scores van de hulserts-oplelders met behulp van een t-toets voor gepaerde waarnem Ingen. 
Tabel 6-7: Gemiddelden en standaarddeviatles wan de scores wan 38 hulsartsop leiders op do Mastrlichtse Hulsartsenvragenllist.

factor 1 factor 11 factor 11

versle 1 versle 2 versle 1 verslo 2 versle 1 versle 2

atiltudescore

$\begin{array}{lrrrrrr}m & 3.4 & 3.4 & 4.2 & 4.2 & 2.6 & 2.5 \\ \mathrm{~s} & .44 & .44 & .36 & .34 & .74 & .84\end{array}$

gepoolde score

$\begin{array}{lrrr}\text { in } & 3.4 & 4.2 & 2.6 \\ \mathrm{~s} & .40 & .30 & .63\end{array}$

Tabel 6-8: p-waarden blj toetsing van verschill en tussen opvattingen van studenten en huisertsopleiders (t-toets, tweezlJalg) op de Maastr lchtse Hul sartsenvragen lijst.

\begin{tabular}{|c|c|c|c|c|}
\hline \multicolumn{2}{|c|}{ factor 1} & \multicolumn{2}{|c|}{ factor 11} & factor 111 \\
\hline beg in & elnd & beg In & elnd & beg in \\
\hline
\end{tabular}

$\begin{array}{lllllll}\text { stagegroep } 1 & .001 & n \cdot s . & n . s . & n . s . & .01 & .01 \\ \text { stagegroep } 11 & .02 & n \cdot s . & n . s . & n \cdot s . & .02 & n \cdot s .\end{array}$

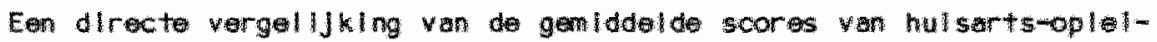
dors on studenter geat an, dat zo ar werschllan an het begln

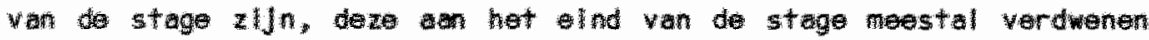
215

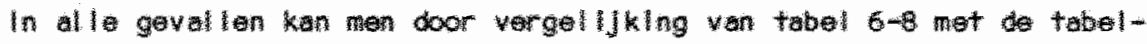

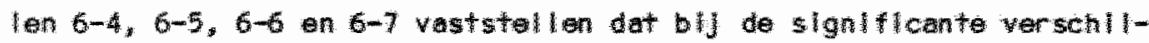
len de studenten hoge scoren den de hulsarts-oplelder. Deze resultaton suggereren, dat studenten zlch contormeren as de opvatingen van hulsartsen net betreklng tot arts-patient-relotio.

olt brengt ons bll de derde wregstelling: wat is de ralate tussen opvatingen van de hulsarts-oplelder on do van de student die la 
zljn praktljk heeft gewerkt.

In tabel 6-9 zljn de correlatles weergegeven tussen de scores van de studenten (voor en na de stage) en de gepoolde score wan de hulsartsoplelders. Gezien de aard van de wrasgstelling zlljn de belde stagegroepen hler tesamen genomen, zadat ledere correlatle berekend is over 45 paren scores.

Tabel 6-9: Correlaties tussen de attltude van studenten en hullsartsoplelders.

$$
\text { begln van de stage elind van de stage }
$$

$\begin{array}{lrr}\text { factor 1 } & .30 & -.17 \\ \text { factor } 11 & -.16 & .25 \\ \text { factor } 111 & .15 & .09\end{array}$

$\mathrm{p}<.05$

Uit tabell 6-9 blijkt dat er aan het begin van de stage oen relatle bestalat tussen de opvattling van oplelders on studenten over het geven van Informatle. Aangezlen blj de plaatsing van studenten blj hun oplelder opvattingen over arts-patlënt-rellatie geen rol hebben gespeeld, dient dit als een toevallige overeensteming te worden aangemerkt. Aan het ellnd van de stage blijkt or en relatie te bestaen tussen de opvattingen van de studenten on hun opleider met betrekking tot het belang van psycho-sociale problematlek. Het vinden van signiflcante correllatle an het elnde van de stage is ochter geen afdoende beantwoording van de vraag in hoeverre de hulsarts-oplelder Invlaed hoeft op de opvattingen van de student. Daartoo dienen de verschlllen tussen de correlaties aan het begin en aan het elnd van de stage getaetst te worden. Ton aenzien van factor 1 blljkt de relatle tussen de opvattingen Inderdaad te verdw Unen (fisher-toets, signiflcantle 5x). Het ontstaan wan de relatle tussen de opvattlingen met betrekking tot factor 11 kan met behulp van dezelfde toets nlet bevredligend worden aangetoond (FIsher-toets, slgniflcantle 10\%). Men kan hler dus hoogstens spreken $v$ an een trend in gegevens. Opmerkelljk is overlgens dat met betrekkling tot de factoren 1 en 111 , warop de scores wan de studenten 
genlddeld dadiden tljdens de stage, geen relatle kon worden aangetoond mat de opvattingen wan de hulsarts-oplelder.

De rosultaten vam de Maastr lchtse Hulsartsen vragenll ij st samenvattend bl ljkt dat er gemlddeld geen veranderling in de positieve attitude optreedt ten aanzion van de factor aandacht voor psycho-sociale problematlek.

Dit impllceert nllet, dat or geen verander Ingen in attlitude optreden bij Individuele studenten, maar het netto-resultat voor de groep is nikll. Ten aanzlen van de veranderingen die optraden werd cen zwakke relatle geconstateerd met de opvattingen van hulsarts-oplelders.

Ten aanzlen van de factor bereldheld tot het geven wan informatle aan patlënten werd een duldellJke dalling van de attitudescores geconstateerd. Deze dalling kon nlet worden gerelateerd aan de opvattingen van de hulsarts-oplelders.

De vraag die rljst is, of hler sprake is van bogenomen "cynllsme", zoals in de Inlelding van dit hoofdstuk beschreven.

BlJ de beantwoording van dle vraag dient allereerst in aanmerkling te worden genomen, det de scores aan het begin van de stage hoger zlJn, dan dle van en grote referentlegroep in het onderzoek van van Loon \& Schmldt (1977). Dit zou erop kunnen dulden, dat deze studenten welllcht over ldeall stlisch aan de stage beginnen. Een zekere dalling van de scores zou dan aangemerkt kunnen worden als een blljk van het ontwlkkelen van een reallstische attlitude. Bij groep I zou de diling daarnaast cok in verband gebracht kunnen worden met het ger Ingere vaardigheids- en competentleniveau, zoels geconstateerd in hoofdstuk 5 . Informat le verschaffen is immers pas mogel ljk, wanneer men over de kennils en vaardigheden beschlkt on en patlënt lets mede te delen. Het is niet uitgesloten det de studenten ult groep I daarmee meer moelte hebben dan de studenten ult groep 11 . UIt soclaal-psychologische IIteratuur is bekend, dat dlscrepanties tussen attituden en feltell ljke handel ingsmogell Ijkheden kunnen lelden tot het aanpassen van de opvattingen an die mogelljkhoden (FIshbein \& Azen, 1975).

Op factor beschlkbaarheld voor de patient werd een llchte daling In de scores geconstateard in de rlichtling wan de gemeten attltude van de huisarts-oplelders. Evenals bij factor II kon geen direct verband tussen de at+ltude van studenten en dle van hum oplelders gevonden worden. Dit slult overlgens nlet ult, dat studenten belnvloed worden door hun oplelders, bljwoorbeld door de feltelljke wijze van praktljkvoering. Deze is in het onderzoek nlet gemeten en behoeft op zich geen 
eenduldige relatie te vertonen met de gemeten attitude van oplelders.

De gevonden veranderingen in attitude zijh zeker nlet van dlen aard, dat gespraken kan worden van toegenomen cynisme of onverschllligheld ten anzlen van relevante aspecten in de arts-petient-relatio. Anderzijds onderstrepen de uitkomsten het belang van onderwljsactiviteiten tijdens de stage, die nlet direct gekoppeld zijn aan het contact met patlënten. Reflectle op het elgen handelen on het leren onderkennen van gedragsalternatleven vormen belangrijke elementen in de nuancering van attituden.

6.5. Het cordeel wan oplelders over het functioneren van studenten in relatle tot patlënten.

Een aantal vragen in de programma-evaluatlevragenlljst, dle daor de opleiders na 4 en 12 weken werd ingevuld, hebben betrekkling op het functioneren van studenten in relatle tot potlënten. Deze dordelen kunnen als een indicatie voor en professionele attitude beschouwd worden. In tabel 6-10 zijn deze vragen en de gemiddelden en standaarddevlatles per groep weergegeven.

De erste vraag kan als algemene oplnie van de opleider over het optreden van de student beschouwd worden, warin niet alleen een oordeel wordt gegeven over zlJn benadering van patlënten, maar waarin ook andere elementen een rol kunnen spelen. De andere vragen hebben direct betrekking op antal aspecten van het contact dat de student met patienten heeft. BlJ dit alles dient men te bedenken, dat de oplelder de student $\mathrm{nlet}$ voortdurend observeert tijdens zijn omgang met patleanten. De cordelen dienen dan ook als globale oplnles beschouwd to worden.

De resultaten geven aan, dat het cordeel van hulsarts-oplelders over het optreden van studenten duldelljk positlef 15 .

De verschillen in cordelen tussen de aanvangsfase on het ell nd van de stage ën tussen de belde stagegroepen blijken in geen enkel goval slgnificant. 
Tabel 6-10: 0ordeel van oplelders ower het functioneren wan studenten in relatie tot patlenten.

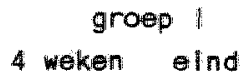

2. De student gedraagt zich zoalls ik det wen anstand artsi werwacht.

3. De student legt gemakkel IJk contacten met patienten.

4. De student benadert de patlënten op een rustige, professionele manler.

5. De patiënten IlJken het nlet vervelend te winden door de student onderwraagd te worden.

6. De patlërten $111 \mathrm{Jken}$ het nlet vervelend te WInden door de student onderzocht the worden.

$\begin{array}{llll}1.6 & 1.8 & 1.7 & 2.0 \\ .73 & .92 & .64 & 1.10\end{array}$

1.41 .5

$.73 \quad .59$

$1.7 \quad 1.9$

$.67 \quad 1.16$

$1.7 \quad 1.9$

1.92 .0

$.81 \quad .74$

.62 .89

$\begin{array}{ll}1.4 & 1.6 \\ .59 & .58\end{array}$

$1.6 \quad 1.6$

$.67 \quad .59$

groep II.

4 weken elnd 


\section{Hoofdstuk 7 \\ Beoordeling van de verslaglegging}

7.1. Inlelding.

De journaals, die door studenten gemaakt worden maar aanlelding van hun contacten met patlënten spelen in de stage-opzet een cruclale rol in de communicatie tussen student, oplelder en begelelder. Daarnaast wordt met het maken van journaals becogd de student te leren zlj.jn bevindingen op en ordelijke en systematische wijze vast te leggen.

Tijdens de stage worden de journaals niet formeel op hun kwalitelt becordeeld. Wel wordt van de hulsarts-begelelders verwacht, dat zllj de kwalltelt van de verslaglegging met de studenten in hun groep bespreken.

Om ne to gaan hoe de kwallitelt van de verslaglegging is en in hoeverre er en eventuele kwallteltsverbetering tijdens de stage heeft plaatsgevonden werd na af loop van de stage een pagling ondernomen om de verzamelde journaals te beoordelen.

7.2. Wijze van becordelen.

Allereerst werd gepoogd een antal criterla te vinden warop verslagen becordeeld zouden kunnen worden. In felte gaat het daarbij on twee typen criterla. In de erste plaats criterla, die samenhangen met do kwalitelt van het professloneel handelen van de student: heeft de student, gegeven de klacht wan de patlënt, de julste gegevens verzameld. In de tweede plaats zou men dienen te beschikken over crlterla, die betrekking hebben op de technlek van het verslagleggen, bijvoorbeeld is het verslag ingedeell volgens de categorleän wan de probleemgeor lënteerde verslaglegging.

Na antal pogingen on colterla voor de verslaglegging te ontwikkelen moest worden vastgesteld, dat door het ontbreken van gegevens ult 
andere bronnen over de aard van de klachten wan de gepresenteerde patienten en thet ontbreken van gemeen geaccepteerde werkwijzen in de hulsartspraktllk on gedetall llerde analyse wan de kwalltelt wan de verslaglegging onultvoerbaer zou zljn.

Anderzljds waren onder zoeker en hulsarts-begelelders het erover ens, dat wel gen global cordeel over ven verslag is te geven. Een dergelljk oordeel representeert dan meer de acceptabllitelt van de verslaglegging dan de objectleve kwaliteit. Aangezlen naar de mening van de hullsarts-begelelders de wergel ijkbaarheld van de becordeling beter zou $z \mathrm{Jjn}$, wanneer Journaals met een vergell Ikbare Ingangsklacht zouden worden beoordeeld, werd besloten twee veel voorkomende klachten, waarblj men een zekere ultgebreldheld van anamnese en onderzoek mag verwachten, In het beoordel Ingsonderzoek op te nemen. Gekozen werd voor rugklachten bulkklachton.

Van ledere student werd steds het erste ingelleverde journaal met de betreffende klacht ult de verste vler wekn van de stage gesellecteerd on latst ingeleverde Journaal ult de laatste vler weken van de stage. In het onderzoek zlJ. al leen dle studenten betrokken, waarvan volgens deze or lterla 4 verslagen konden worden geselecteerd.

In totaal bleek dit bif 25 van de 45 studenten mogel ljk

op ze wijze ontstaan 4 groepen versllagen, zouls wergegeven in 11 guur 7-1:

Flguur 7-1: Schemat/sche opzet van het onderzoek van de verslaglegging.

klacht

$+1 j d v a k$

\begin{tabular}{|l|l|}
\hline $\begin{array}{l}\text { ber ste 4 } \\
\text { weken }\end{array}$ & $\begin{array}{l}\text { laatste } \\
\text { weken }\end{array}$ \\
\hline rug & rug \\
\hline bulk & bulk \\
\hline
\end{tabular}


Gezlen het lage aantal studenten warvan 4 verslagen ter beschlkking waren en gezlen het gegeven dat het hlerblj vooral studenten ult de tweede stageperlode betrot, is afgezlen van een vergell ljking tussen de twee stagegroepen.

In deze opzet kunnen de twee uragen, dle an het bog in van deze partgraaf werden geformuleerd in princlpe beantwoord worden.

Om en zo abjectlet mogelljke beoordelling mogell ljk te maken werden de geselecteerde verslagen ultgetypt, zonder vermelding van de naam van de student, de datum van het contact on de eventuel artekenlingen van de hulsarts-oplelder of hullsarts-begelelder. leder versllag kreeg een vijf fclj fer ige code.

Twee hulsarts-begeleiders verklaarden zlch bereld de verslagen onafhankell Ik van elkaar te becordelen. De technlsche voorbereliding van deze becordel Ing nam zoveel tI Jid in beslag, dat aangenomen mag worden dat de betrokken becordelaars verslagen van studenten ult hun elgen groep nilat hebben kunnen herkennen.

De becordel ingsopdracht luldde als volgt:

"De wraag "wat is een goed verslag?" is nlet eenduldig te beantwoorden. In het globaal oordeel zullien eem aantal elementen een rol spelen, zoals:

- Klachtpresentatie.

- Conslstentle van beschreven anannese, onderzoek en ther ap levoorstellen.

- Zinvolheld van de beschrevon activitelten in hot llicht van de klacht.

- Overzichtel Ijkheld van het verslag.

- Aanwezlghell van essentiöle informatle in het Ilcht van de klacht of -negatlef geformuleerd-welke informatlie $\mathrm{m} / \mathrm{s}$ Je?

leder Journaal dlent te worden becordeeld op 10-puntsschal: tien Is ultmuntend en ëen zeer slecht.

Het zal zeker niet eenvoudig zijn on de beordeling in een clJfer ult te drukkem, vandaar enlge suggestles:

- Lees een antal verslagen door on je ean beeld te vormen van de verschlllen in kwalltelt.

* Dit hangt direct samen met het lagere aantall lngeleverde journaals door de tweede stagegroep. 
- Bggin dan met het goven van een cljfer an het eerste verslag. De verslagen II iggen in 1 ll lekeur lge volgorde.

- Gebrulk de 10-puntsschaal zo goed mogelljk: "een slecht werslag een lag cljter, een zeer goed verslag een goed cljfer."

\subsection{Pesultaten.}

Allereerst is nagegaan in hoeverre de cordelen van de twee becordelaars met elkar overeenstemden. Blj de rugklachtenverslagen bleek de correlatle tussen de cordelen .44 en blj de bulkklachtenwerslagen .39. Belde correlaties zijn welliswar signiflcant, dat wil zeggen dat er oen samenhang tussen de beoordel ingswlyze wan belde beoordellars is, maar deze samenhang is nlet sterk. In de verdere rapportage is het gemilldelde cordeel van belde becordelaars als ultgangspunt genomen.

In tabel 7-1 zljn de resultaten van de kwall telltsbeoordeling voor de belde klachten samengevat. Aangezlen de verwachting luldde, dat aan het elnde van de stage journaals van een betere kwalltelt zouden worden afgeleverd zijn de verschlllen éénzijdig getoetst met behulp van de t-toets voor gepaarde waarnenlngen. Ult de resultaten blljkkt, dat er geen kwallteltsverbetering optreedt in de loop wan de stage. De verschllien blj de bulkklachten zIJn zelfs zodanlg, dat van een signiflcante kwal iteltsvermindering gesproken kan worden.

Tabel 7-1: Kwall teitsbeoordelling van Journaals met betrokking tot rugklachten on bulkklachten, gebaseerd op gegevens van 25 studenten.

$$
\text { eerste } 4 \text { weken laatsto } 4 \text { weken slgn. }
$$

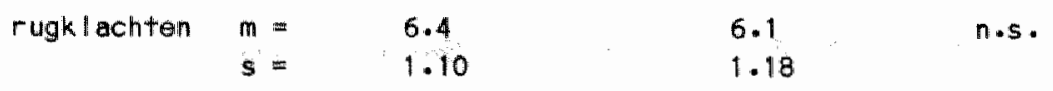

$\begin{array}{rrrr}\text { bulkklachton } m= & 6.7 & 6.1 & \mathrm{~m} \\ \mathrm{~s}= & .76 & 1.14 & \end{array}$


Het algemeen niveau van de beoordeelde verslagen ligt tussen 6 en 7 op een 10-puntsschaal. In schoolse termen is hier sprake van een voldoende niveru, maar de spreidling rand de gemiddelden geeft aan dat dit voldoende ni veau nlet door al le studenten gehaald wordt.

De resultaten zljn wellswaar gebaseerd op en kleine steekproef, maar sluiten anderziljds aan bij de in hoofdistuk 4 wermelde gang wan zaken rond de versllaglegging. Aangezlen de verslaglegging een belangrijke rol in de stage-opzet speelt als aangrijpingspunt voor onderwils- en leeractivitelten is een geniddeld goed niveau van verslaglegging noodzakelijk.

De matlge resultaten, dle hler gevonden worden hangen waarschijnlijk nauw samen met de onervarenheld van studenten; oplelders en begeleiders met de mogel IJkheden van verslaglegglng. Het gegeven, dat het nIveat van verslaglegging eerder minder wordt, dan toeneemt, duldt or $o p$, dat wan al doende verbeteren wan deze vaardlgheld op zlch nlet veel werwacht mag worden. Explliclete cefening voorafgaande aan de stage en meer aandacht voor de wijze van verslaglegging tijdens de stage kunnen deze gang van zaken verbeteren. 


\section{Hoofdstuk 8}

\section{Kennistoetsing}

\subsection{Inlelding.}

oit laatste hoofdstuk met betrekking tot de stage in het studle laar 1978/79 heeft betrekking op de resultaten van studenten op kennlstoetsen. Zoals in hoofdstuk 3 reeds werd alangegeven speelt de kennlistoetsling tljdens de stage en ondergeschllkte rol. Dit hangt samen met de randvoorwarden voor kennlstoetsling, die door de facultelt gestell werden. Voorts $k$ an met verwljzing naar de opvattingen van de Groot (1974), zoals besproken in paragraaf 1.3 .1$. , de stelling verdedlgd worden, dat de nadruk bld de beoordeling van studleprestatles in stages niet op kennlstoetsing gelegd dlent te worden, maar op het praktisch handelen van studenten. Welke probllemen de student aangeboden $\mathrm{krijgt,} \mathrm{hoe} \mathrm{hlj} \mathrm{deze} \mathrm{problemen} \mathrm{benadert} \mathrm{lin} \mathrm{termen} \mathrm{vam} \mathrm{anamnese,} \mathrm{onder-}$ zoek evaluatie en plan, vormen de belangrljkste elementen in deze praktische ervaring.

Het verkrijgen van informatle over deze aspecten werd dan ook door de planningsgroep beschouwd als het meest centrale doell blj de opzet van een evaluatleplan.

Competent handelen wordt echter in belangrijke mate bepaeld door ken$n i s$, vandaar dat een of andere vorm van kennistoetsing in en stageprogramma zeker zinvol is. In paragraaf 8.2. wordt aandacht besteed aan de drle formatlevo toetsen, die HIJdens de stage aan studenten werden woorgellegd. In paragraaf 8.3. worden de voortgangstoetsresull taten $v a n$ de studenten nader beschouwd. Wegens een aantal daar te noemen factoren wordt in die paragraaf tewens andacht besteed an de voortgangstoetsresultaten van latere jaargangen studenten. 
8.2. Formatleve toetsen.

8.2.1. Samenstelling van de toetsen.

Tijdens de stage werden dr le toetsen aan de studenten voorgelegd; two daarvan werden door de planningsgroep samengesteld; de derde toets was de zogenaande Rotterdamse hullsartstoets (Tober, van der Klauw \& Groeneveld, 1977).

De eerstgenoemde taetsen waren bedoeld om de kennis van studenten met betrekkling tot de 23 klachtengroepen (zle tabel 2-3) te toetsen. Door 5 hullsartsen verbonden aan de faculteit werden per klacht oen aantal vragen van het type julst/onjulst geformuleerd. Wit dit materlaal werden twe paralleltoetsen samengesteld, bestaande uit 115 vragen. ledere klachtengroep werd door 5 vragen gerepresenteerd.

De eerste toets werd afgenomen halverwege de stage (tussentljdse toets), de tweede toets aan het elnde van de stage (elndtoets). Tenelnde de studenten $\infty$ in meer absolute termen te kunnen informeren over hun kennisnlveau, werden belde toetsen onder "examenomstandigheden"t vaorgelegd an 8 arts-assistenten van de hulsartsoplelding in Maastrlcht. Hierdoor konden de toetsscores van studenten vergeleken worden met en externe referentlegroep.

De Rotterdamse toets voor hulsartsen is een meerkeuzetoets, dle werd ontwikkelld door de vakgroepen Onderwijsresearch en Hulsartsgeneeskunde van de Erasmus Universitelt. De ontwlkkeling vond plaats in het kader van en evaluatie van de hulsartsoplelding. De toets bestaat uit 33 meerkeuzevraglen, met verschillende aantallen alternatieven. De auteurs achten het instrument om twee redenen nlet geschlkt om in de gerapporteerde vorm als sumbatiof evalluatle-instrument in de huisartsoplelding te hanteren: de vragen sluiten inlet precles aan blj en later geformuleerd evaluatlekader en de resultaten in het vooronderzoek geven onvoldoende informatle over het discriminatle-vermogen van de toets, aangezlen de bereldheld om aan het onderzoek deel to nemen bij en aental onderzachte groepen gerling bleek (Tober, van der Klauw \& Groeneveld, 1977). Nlettem in is deze toets in dit onderzoek opgenomen, aangezien deze toets en van de weinlge pogingen in Nederland vormt am voor de hulsarts relevante kennis te taetsen on aangezlen de respons van de pas af gestudeerde basisartsen in het Rotterdamse vooronderzoek (50\%) toch voldoende groot is on de gemiddellde scare van deze groep als vergelijking te gebrulken. 
De Potterdanse toets werd an het elnde van de stage afgenonen. De dr le hlervoor genoeinde toetsen werden steeds onder "examenomstandigheden" door studenten gemakt. Na verwerking ontvimgen de studenten de tootsultslag, warbl] naas* de elgen score ook vermeld werd de geniddelde score wan de stagegroep de gemlldelde score van de betreffende referentlegroep van basisartsen.

TlJdens de twee stageper loden werden identleke toetsen gebruikt. Aangezlen de toetsen voor de student ultslultend een formatieve betekenls hadden, en de studenten niet op de hoogte waren, dat de toetsen Identlek zouden $z|J| n_{\text {, }}$ forwlJl or bovendien zes maanden lagen tussen de toetsmomenten vam belde groepen, mag verondersteld worden, dat de resultaten van de tweede stagegroep nlet geflatteerd worden door bekendheid met het toetsmaterisal.

\subsubsection{Resill taten.}

In tabel 8-1 zljn de resultaten op de drle toetsen voor beide stagegroepen weergegeven. De scores van de studenten zljn uitgedrukt als percentage van de scores van baslsartsen in de respectievel ijke referent legroepen.

Tabel 8-1: Toetsresultaten van studenten op drle formatleve toetsen, uitgedrukt als percentage van de score van een referentiegroepbas I sartsen.

$\begin{array}{llll}\text { betrouw- } & \text { groep } / & \text { groep } \| \text { slgnlflcantle } \\ \text { baarheld } & m & \mathrm{~m} & \text { s t-toets }\end{array}$

$\begin{array}{lcccccc}\text { tussentijdse toets } & .75 & 86 \% & 25 & 96 \% & 16 & n- \\ \text { ellndtoets } & .68 & 82 \% & 26 & 96 \% & 20 & 0.10 \\ \text { Rotterdamse toets } & -- & 82 \% & 18 & 94 \% & 11 & 0.01\end{array}$


Utt deze cijfers valt af the lezen, dat de drle toetsen vergelljkbare resultaten opleveren. De tweede stagegroep scoort op alle toetsen hoger dan de eerste stagegroep. Duldelljk is ook dat binnen de groepen sprake is van heterogeniteit in kennlismiveau. De tweede stagegroep levert ap de drle toetsen een score, dle goed vergellykbaar is met dle van afgestudeerde baslsartsen; de eerste stagegroep bllfft hlerblj duldelljk achter.

Naast het beschouwen van de resultaten op de toetsen afzonder $11 \mathrm{Jk}$ is het evenzeer interessant on op basls van een comblnatie van de toetsresultaten een beeld te schetsen van het kennllsnlveau van de studemten.

Hiertoe zijn de toetsresultaten onderworpen aan een procedure, dle thans ten grondslag ligt aan de beoordelling wan toetsprestaties in de facultelt der geneesikunde. De basls van deze procedure is, dat leder toetsresultaat wordt gecategor lseerd als wolloende $(+)$, twilf felachtig (0) of onvoldoende (-) en dat vollgens een combl natleregel de opeenvolgende toetsresultaten aan elkaar worden gerelateerd. Deze comblnatioregel is weergegeven in tabel $8-2$.

Tabel 8-2: Comb Inatieregel voor toetsprestaties in de faculteit der geneeskunde.

bestaand oordeel toegevoegd

toetsresultaat nleuw ordeel

$\begin{array}{lcr}+ & + & + \\ + & 0 & 0 \\ + & - & 0 \\ 0 & + & + \\ 0 & 0 & 0 \\ 0 & - & - \\ - & + & 0 \\ - & 0 & 0 \\ - & - & -\end{array}$


Analocg aan dezo werkuljze zijn de toetsiresultaten in dft onderzoek als volgt aan ell karar gerelateerd:

1. De resultaten op de drie toetsen ziln gecategorlseerd als "op basisartsniveau" $(+)$, "fwijfelachtig" (O) of "onder basl sartsniveau" (-). Als basls voor de categorisering is de scoreverdeling van de referentlegroepen van baslsartsen gebrulkt. Een resultaat is op baslsartsnlweau, wanner de student hoger scoort dan het genlididelde van de referentlegroep minus de halve standaarddevlatio. Een resultaat is twijfelachtilg, wanneer de score wan de student zlch bevindt tussen eenmal de standaarddevllatie en de halve standaardieviatle onder het gemlddelde wan de referentiegroep. Een resultaat is onder het basisartsiniveau, wanneer de score lager is dan het germiddelde van de referentlegroep minus de standaarddewlatie.

In tegenstelling tot de relatieve categorliseringsregel, die ten grondslag llgt aan de beoordeling van studieresultaten in het thans vigerende examenreglement van de faculteit der geneeskunde is hler een absolute grondslag gekozen, aangezlen het doel wan de procedure hier is, en schatting te geven van het kennlsniveau van studenten in relatie tot het niveau van basisartsen.

2. Volgens de combinatleregel ult tabel 8-2 zljin de resultaten van de drle toetsen, in volgorde van afname, vervolgens gecomblneerd tot een elindoorder.

Toepassing van deze procedure levert het in tabel 8-3 weergegeven resulltagt op.

Tabel 8-3: Kennismiveau van studenten op basis van een combinatle van toetsresultaten.

De gatallen representeren het aantal studenten per categorle.

groep 1

$\begin{array}{lrl}\text { bas I sartsniveau } & 6 & 9 \\ \text { twijfelachtig } & 2 & 8 \\ \text { onder baslsartsniveau } & 16 & 4\end{array}$


In het vorafgaande zljn de toetsresultaten van studenten afgemeten aan het eindnliveau van de oplelding tot baslsarts. Dit betekent nlet, dat de doelstelling van de stage is om studenten te brengen op dat niveau. Een dergellijke vergelljking makt het echter wel mogelljk de discussie te voeren over de uraag in hoeverre dit resultat bevredlgend is *

Zoals uit tabel 8-1 al zichtbaar was zijn de studieresultaten van de tweede stagegroep op voor de stage relevante kennlstoetsen beter dan dle van de eerste stagegroep. Dergel Ijke verschillen zouden voor oen deel veroorzaakt kunnen zijn door verschlllen in kennis tussen de twoe groepen aan het ellnde van het voorafgaande studlejaar. Hoewel belde groepen niet signiflcant van elkaar verschlliden op de scores op de voortgangstoets aan het einde wan het vilerde studlejaar, was de score van de tweede groep lets hoger ( $z$ le tabel 8-5).

De overige verschlllen zouden verklaard kunnen worden door een tweetall effecten, dle belde comsequentles zouden kunnen hebben voor de toekomstige stageopzet.

De cerste verklaring zou kunmen zijn dat studenten alleen dan met wrucht zlch de relevante kennlis in het PMOH kunnen ellgen maken, wanneer zij reeds ervaring in en andere klinische setting hebben opgedaan en daardoar meer +1 Jd en energle kunnen steken in het bestuderen van voor de hulisartspraktijk relevante zaken.

stages in een zlekenhulssetting zouden dan een faclliterende working hebben op het leren in de huisartspraktljk.

De leerwinst van de tweede stagegroep zou dan blinnen de stage $\mathrm{PMOH}$ $z 1$ In opgetreden.

Een geheel andere verklaring is, dat studenten in hun zlekenhulsstage zoveel voor de hulsartspraktijk relevante zaken geleerd hebben, dat de leerwinst feltell ljk woorafgaande aan de PMCH-stage is geboekt.

Aangezlen de onderzoeksopzet nlet toellat conclusles te trekken over leerwinst blinnen de stage, versus leerwinst voorafgaende aan de stage Is het onmogelijk de gevonden verschlllen a an een van belde verklarllngen the to schrijuen.

Wel laten belde verklaringen de conclusle toe, dat platatsing van de stage an het begin van het vijfde jaar ertoelleldt, dat aan het elind van de stage studenten in het algemeen mog nlet over de kennis beschlkken op het gebled van de huisartsgeneeskunde zods die van een baslsarts verwacht mag worden.

Gegeven het felt, dat de studenten ult groep I nog een langer programma van zlekenhulsstages voor de boeg hebben kan ult de verschillen op zich nlet geconcludeerd worden, dat deze studenten aan het elinde van 
hun oplelding beschlkken over minder kennls. Wel kan men $z$ ich de vraag stellen, in hoeverre het kenn Isnlveau van studenten beperkingen oplegt aan het berelken van een aental stagedoelstellingen. Hierbll kan ook het cordeel van de hulsarts-oplelders over de kennls van studenten betrokken worden. In tabel 8-4 zljn de antwoorden van de oplelders op de wraag of de student te weinig kennls bezat on het PMOH met vrucht te wolgen weergegeven.

Tabel 8-4: Oordeel van de hulsarts-opleiders over het kennisniveau van studenten.

$$
\text { Groep } 1 \text { Groep } \|
$$

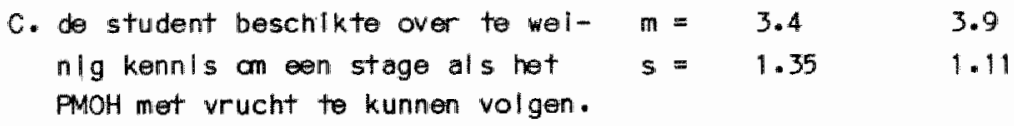

(antwoorden op en 5-puntsschaal: 1 = volled lg eens, 5 = volledig oneens.)

Hoewel de resultaten gemlddeld een bevredigend antwoord opleveren, kan uit de sprelling in de resultaten worden afgeleld, dat volgens de opleliders en aental studenten (mett name in de eerste stagegroep) naar hun oordeel onvoldoende kennis bezaten on een dergelljke stage te volgen *

Uit deze resultaten mag de voorzlchtige concl usie wor den getroklken dat plaatsing van de stage aan het begin van het vijfde studlellar niet zonder rlsico's is. Een betere voorberelling (of scherpere selectie) in het voorafgaande studle a ar kan deze irlsico's mogelljk verkleinen. Dok de eerder gepresenteerde resultaten met betrekking tot de valardlgheden (zle hoofdstuk 5) ondersteunen deze conclusle. 


\subsection{Voortgangstoetsresultaten.}

In paragraaf 3.2 .1 . Is de voortgangstoets reeds beknopt geintroduceerd als een instrument, dat bedoeld is om het gehele kennilsdomelin dat voor de baslsarts relevant is, te testen. De toets wordt viermaal per jaar door alle studenten uit alle studiejaren afgelegd. ledere toets bestaat ult ongeveer 350 juilst/onjulst vragen, dle volgens een bepalde verdeelsleutel de verschillende, vaor een baslsarts relevante, vakgebleden binnen de geneeskunide representeren.

De vragen worden at randam ult een vragenpool getrokken. Voordat een getrokken vraag in de toets komt, wordt hij zowel inhoudelljk als vormtechnisch door een comlssie, bestaande ult artsen met een verschilliende specialisatle, becordeeld. leder toets wordt ook door een aantal artsen, de zogenaamde referentlegroep, genaakt. Op deze wiJze is het mogelljk de scores van studenten in zekere mate te corrigeren voor fluctuaties in de moellljkheldsgraad van opeenvolgende tootsen.

De beschikbaarheld van en dergelljk instrument bledt in princlipe de aantrekkelijke mogelijkheld om de kennlsontwikkeling van de in het onder zoek betrokken studenten te volgen.

Een praktisch problem blj en dergelljk onderzoek is echter, dat de toetsafnamedata niet overeenstemmen met de begin- en elndpunten van de stages, zadat van een eenduldige effectmeting geen sprake kan zljn. In tabel 8-5 zijn de voortgangstoetsresulttaten wan belde stagegroepen weorgegeven van de laatste toets in het vierde studlejaar tot en met de laatste toets in het vijfde studlejar. De scores ziln ultgedrukt ols percentage van de score van de referentlegroep om de onder llnge vergelljkbaarheld wan de resultaten op de verschillende toetsen te vergiroten.

Een belangrljk gegeven in deze tabel is, dat bellde groepen an het einde van het vierde studlejar weinlg van olkar verschillen in kennis z zodat de twee stagegroepen op dlt bellangrljke aspect als gelljkwardlg kunnen worden beschouwd.

Het trekken wan conclusles over de kennlsontwikkelling wam studenten aan de hand van deze gegevens blijkt echter zeer moellijk. Het mag $1 \mathrm{~m}$ mers betrekkel ijk onwaarschljnlljk worden geacht, diat belde groepen tussen november 1978 en mel 1979 nlets geleerd zouden hebben.

\|n en ultgebrelde analyse over de voortgangstoetsgegevens in: het studlejar $1978 / 79$ geven Imbos \&erwljnen (1982) aan, dat met name kllnische kennis onvoldoende in de toets gerepresenteerd was, wat deels het gevolg is van de ontwikkelingsproblemen van de voortgangstoets. 
Tabel 8-5: Voor +sgangstaetsgegevens $1978 / 79$.

De scores zljn uitgedrukt als percentage van de score van een refarentlegroep bas I sartsen.

Toetsdatum

Groep I

Groep $\mid 1$

$\begin{array}{rllll} & \mathrm{m} & \mathrm{s} & \mathrm{m} & \mathrm{s} \\ 22-6-78 & 82.6 & 12.81 & 8.4 .8 & 12.04 \\ 17-11-78 & 86.3 & 11.81 & 91.3 & 13.29 \\ 19-1-79 & 85.8 & 13.45 & 90.8 & 10.22 \\ 9-3-79 & 83.4 & 11.39 & 92.7 & 10.69 \\ 11-5-79 & 85.6 & 11.56 & 91.1 & 10.90\end{array}$

Ten tijde van het onderzoek werd deze toetswljze pas twee Jaar toegepest on was de vragenbank nog volop in opbouw.

Wanneer men afzlet wan de vergelljking van leder opeenvolgend toetsmoment, den blljft alleen de Indruk over, dat de volgorde warin de stages gevolgd worden enlge invlloed op de kenillsontwlkkelling hebben. Hierblj dlent echter aangetekend te worden dat stagegroep Ill rulm een maand erder met hun stages begonnen, zodat bllj al lo meetmonenten tijdens het vijfde studiejaar dit verschll in lengte van het gevolgde programa anwezlg is *

Gezien het tljdsverloop tussen het studlejaar, warlin het onderzoek is ultgevoerd en de rapportage is het mogelljk na te gaan, in hoeverre de voortgangstoetsgegewens in latere jaren meer duldell Jkheld kunnen bleden. In tabel 8-6 $\mathrm{z} / \mathrm{J}$ deze resulltaten weergegeven voor dr le opeenvolgende Jaargroepen; waarblj de najarsgroepen vergel ijkbaar zijn met groep I en de voorl ararsgroepen met groep 11 .

De voor Jarsgroepen hebben, evenals tijdens het studlejaar 1978/79 op alle toetsmomenten in het vijf fe studlejaar rulm een maand langer stage gelopen. De toetsmomenten zlJin wellswar evenwlchtlger over het Jaar verdeeld, mar vallen nlet samen met de beglin-en elndpunten van de diverse stages.

Dok deze gegevens leveren geen duldelljke informatle over de relatio tussen het gevolgde studleprograma en de kennl sontwlkkelling. De grote \#ljn is, dat ar tussen het elinde van het vlerde jaar en het ellnde van het viJfde studlejaar In beide stagegraepen een duidel Ije kennistoe- 
name plaatswindt, maar cok hier levert de onderlinge vergelljking van opeenvolgende toetsmomenten een winlg verhelderend beeld op ten aan$z$ lien van mogell ijke effecten van het gevolgde onderwijspragrama.

Welllicht kan men uit het gegeven, dat gedurende he* studiej arar 1981/82 opeenvolgende toetsmomenten een contlnue stljging vertonen afleliden, dat de kwalitelt van de voortgangstoets als meetinstrument voor het totalle relevante kennlsgebied is toegenomen. De gevoelighelld wan de voortgangstoets blljkt echter te gering on de effecten van stageprograma's op de kennistoename van studenten duidelijk vast te stellen.

Tabel 8-6: Voortgangstoetsgegevens van studenten, dle in 1979/80, $1980 / 81$ en $1981 / 82$ het vijfde studlejar volbrachten. De scores zljn ultgedrukt als percentage van de score van een referentlegraep baslsartsen.

\begin{tabular}{|c|c|c|c|c|c|}
\hline stagej aar & \multirow[t]{2}{*}{ tootsdatum } & \multicolumn{2}{|c|}{$\begin{array}{l}\text { nal arsgroep } \\
\text { PMOH }\end{array}$} & \multicolumn{2}{|c|}{$\begin{array}{l}\text { voor J arsgroep } \\
\text { PMOH }\end{array}$} \\
\hline & & $m$ & $\mathrm{~s}$ & m & $\mathrm{s}$ \\
\hline \multirow[t]{5}{*}{$1979 / 80$} & $11-5-79$ & 77.9 & 12.94 & 76.2 & 11.27 \\
\hline & $14-9-79$ & 80.2 & 12.84 & 89.4 & 8.91 \\
\hline & $7-12-79$ & 84.1 & 13.49 & 90.8 & 11.65 \\
\hline & $7-3-80$ & 84.9 & 14.84 & 86.3 & 9.46 \\
\hline & $30-5-80$ & 86.7 & 13.19 & 87.2 & 9.81 \\
\hline \multirow[t]{5}{*}{$1980 / 81$} & $30-5-80$ & 81.0 & 12.13 & $82 \cdot 3$ & 11.42 \\
\hline & $19-9-80$ & 74.8 & 18.67 & 84.9 & $11 \cdot 31$ \\
\hline & $12-12-80$ & 87.5 & 23.66 & 89.0 & 10.01 \\
\hline & $13-3-81$ & 88.1 & 11.09 & 93.3 & 10.61 \\
\hline & $12-5-81$ & 91.0 & 9.56 & 93.0 & 9.75 \\
\hline \multirow[t]{5}{*}{$1981 / 82$} & $12-5-81$ & 70.1 & 12.04 & 77.3 & 14.63 \\
\hline & $25-9-81$ & 77.3 & 11.97 & 84.9 & 13.77 \\
\hline & ||$-|2-8|$ & 78.6 & 12.22 & 86.8 & $14 \cdot 20$ \\
\hline & $5-3-82$ & 84.2 & 9.69 & 94.0 & 12.41 \\
\hline & $14-5-82$ & 88.5 & 11.66 & 94.4 & 10.42 \\
\hline
\end{tabular}


In nawolgling yan een aantal onder zoeksactivitelten rond de voortgangstoets, warbilj relatles tussen studie-actlultelten en bepalde categorleën vragen ult de voortgangstoets worden onderzocht (zle Imbos, van der Lugt en Verwijnen, 1982) is overwogen dergelijke benadering cok hiler toe te passen. Technisch is het mogelljk on de vragen uit de toets, die afkomstig zijn van ben baalde capacitelltsgroep (vakgroep) afzonderllijk te analyseren. Op zich is dit geen perfecte operationalisatie wan de woor het betreffende vakgebled relevante keninls, aangezlen nlet de inhoud van de vraag, maar de opsteller van de wraag het criterlum vormt. Dok deze poging an het kenniswerwerwingsproces te relateren an het stegeprogranmo mislukte, aangezlen het aantal vragen in de verschllllende voortgangstoetsen, afkomstig van de capaciteltsgroep hullsartsgeneeskunde dermate laeg bleek, det de toetsconstructeurs dergellyke analyse nilet uitvoerbaar achtten. 


\section{Hoofdstuk 9 \\ Het PMOH in perspectief: veranderingen, conclusies en aanbevelingen}

9.1. In lielding.

In de woorafgaande hoofdstukken is de ontwllkkelling van het stagemodel geschetst en zlJn gegevens gepresenteerd over het verloop van de stage in het earste reallsatle aar. Het belangrljkste doel van dit hoofilstuk. is aan te geven welke ontwlikkelingen zich in de stage-opzet hebben voorgedaan sinds dat moment, met name in relatie tot het ultgevoerde onder zoek.

Achtereenvolgens wordt ingegaan op de belangrijkste elementen van het didaktlsch model van de stage. De gepresenteerde gegevens zljn voor een deel gebaseerd op elders gerapporteerd onderzoek (RIJntJes, Bouhuljs, Brouwer \& Mol, 1982; 1983).

De slotparagrafen zljn gewlJd aan de mogel IJke ontwlkkelingsllJunen woor dit stageprograme in de toekomst, warblj ook andacht an het kostenaspect wordt besteed.

9.2. Het vertrekpunt voor verdere ontwikkel ing.

Het perspectief wan warult de planningsgroep ne mel 1979 gewerkt heeft an de verdere ontwlkkelling wan het stageprograma kan worden gekarakteriseerd door de dlchterl ljke woorden, warmeo en hulsartsbegelelder zljn verslag over het werloop van de stage beêlndigde: "Keulen en Aken zijin ok nlet in drle maanden gebouwd; wils moeten in het voorjaar wel zallen, maar nlet ook wlllen oogsten."

De planningsgroep kon enerzljds tevreden zljn over datgene wat in korte tijd berelkt was, maar constateerde anderzljds oen aantal zaken, dili bljgestell, ver anderd of verbeterd dlende te worden.

In een aantal bljeenkomsten tussen mel en september 1979 werd het programa wor het studlejaar 1979/1980 ultgewerkt. De planningsgroep be- 
schikte over en grote hovevilheld Informatle en ervarlngen met betrekk Ing tot het programa, warvan ben belangrilk del in de voorafgande hoofdstukken is wergegeven. De algemene concllusle was, det het gtage-ontwerp al zodanig een goed ultgangspunt vormt en ook haalbaar blljkt, mea dat alle doelstellingen nlet in gelljke mate, nlet op alle stageplatisen, nlet door alle studenten en nlet door lledere hulsarts-begelelder gereall seerd worden.

Een op zlch niet verrassende conclusle voor en onderwijsprogramma, dat in hoge mate afhanikellJk is van de inspanningen van zovelen op zoweel platsen.

De bljstellingen en veranderingen kunnen dan cok voor het merendeell beschouwd worden als pogingen om te voorkomen, dat een stage minder geslaugd verloopt. Deels door een betere voorberelding van studenten en oplelders, deels door een nadrukkelljker begelelding tijdens de stoge.

9.3. Do structuur van de stage.

De duur van de stage bleef in het studlejar 1979/1980 gehandhaafd op 13 weken. BIJ een algemene herzlening wan het viJfde en zesde studieJaar is vanaf het studlejar $1980 / 1981$ de duur van de stage gebracht op 12 weken. De redenen daarwoor waren de druk, dle vanult klinlsche wakken werd ultgeoefend on meer tijd ter beschlkking te krljgen en rekenkundige argumenten, dle bij de planning een rol spelen (naast stages van $3,6,8$ en 12 weken is cen stage wan 13 weken nogal $\|$ astig).

In de bespreklingen, dle de plennlngsgroep voerde naar aanlelling van de evaluatle van het studlejear $1978 / 1979 \mathrm{kmam}$ naar voren, dat hot rendement vain de stage gedurende de earste wekwn verhoogd zou kunnen worden, Indien de studenten beter woorbereld aan het werken in de hulsartspraktlljk zoudien beginnen. Wanneer studenten expllaleter voorbereld worden op hat gebeuren in de hulsartspraktllk en op het gehanteerde onderwlJ smodel tIJdens de stage zou, zo werd werwacht, tevens woorkomen worden, dat zlch bepalde problemen voordoen in het functllomeren $y$ an somlge studenten.

Dllt Idee werd concreet vorm gegeven door de eerste week van de stage als Introductleweek to gebrulken met de volgende doelstellingen: 
1. Voorberelding op het functioneren in de hulsartspraktljk.

2. Bevorderen $v a n$ een goede samenwerklng tussen studenten onder lling en met hun hulsarts-begelelder.

3. Formuleren van indlviduele en groepsleerdoelen voor de stage.

Met uitzonderling van een kennlsmaklngsbezoek aan de hullsartspraktijk, warin men kant te werken, bestast het pragrama ult activitelten, dle zlch binnen de facultelt afspellen.

Naast dr le onderwijsgroepsbljeenkansten, waar In met name de doelstelI Ingen twee en drle centraal staan, cefenen studenten in het gebrulk $v$ an het verslagleggingssysteem on worden er bljeenkonsten met dacenten van diverse capaciteltsgroepen georganlseerd. Dit laatste had aanvankelljk het karakter van en bljspljkercursus op gebleden, dlle in het voorafgaande onderwlJs nlet voldoende aan de orde zijn geweest, maar van belang zlijn voor het goed functioneren wan studenten tljdens de stage in de hulsartspraktIJk (0.a. farmacotheraple, KNO en dermatologie).

Vanaf het studlejaar 1981/82 is het accent van deze bljeenkomsten meer komen te liggen op "samenwerkling tussen eorste en tweede $1 / \mathrm{Jn}$ ", warabij) In de groep studenten, In aanwezlgheld wan oen hulsarts met éen van zijn patiënten en een speclallist de kllacht van de patlënt wordt bestudeerd tegen de achtergrond van de zlin van een verwljzing naar de tweede $\| 1 \mathrm{~J}$.

Tenslotte amvat de week een toetsingsmoment voor de kennls en vaardigheden van de student, tenelnde de student en de hulsarts-begelelder te informeren ower de sterke en zwakke kanten van de student. In paragraaf 9.6. zal hlerop verder worden Ingegaan.

Uit de programa-eval uatle kan worden afgeleld, dat studenten een dergell IJk introductleprograme en wardevol onderdeel van het stageprograma vinden.

9.4. Patlëntcontacten on vers laglegglng.

Zoals In hoofdstuk 4 al is geconstateerd trad or in het studlelaar 1978/79 en anzlenll.jke dliscrepantle op tussen de verwachte en de feltelijke ulltkomsten met betrekklng tot de verslaglegglng. Enerzljds correspondeerden de ingeleverde Journasls nlet met de aanbevolen klachtenlljst, anderzljds bleet het aantal ingeleverde Journaals, met 
name tijdens de tweede stageperlode, ver achter blj de geplande aantallen. Wet betreft de aanbewalen klachtenllyst kwam men smel tot de conclusle, dat het welnig zinvol is ean aanbeveling to doen, die niet halbear bll Jkt te zllun.

In plats darvan werd de $11 \mathrm{Jst}$ wan frequent in de Journaalls voorkomende klachten als nlmuw uitgangspunt genanen. Implliclet wordt hlermee erkend; dat studenten nlet op actleve wijze met alle relevant geachte klachtencategorleän in de hulsartspraktljk In aanraking kunmen komen. Afgaande op in het studlejaar 1979/80 en 1980/81 ingelleverde Journaals kan men de conclusle trekken, dat er welnig verander lngen optreden In de belangrljkste klachtencategorleïn, dle door studenten gezlen worden tijdens de stage. De twaalf meest woorkamende categor leën zlj In volgorde van frequentie:

1. Klichten w het beweglingsapparat,

2. klachten vain keel, neus, oren, incluslef gewone verkoudheld.

3. bulkklachten, inclus lef lever en galblas,

4. hoestern en/of benauwdheld,

5. huldaandoenlingen en/of Jeuk,

6. Klachten van nerweus-functionele ard,

7. hootdpijn;

8. plJn op de borst, Incluslef hartklopplingen,

9. hypertensle,

10. $\infty$ ogk I achten,

11. kllachten c.q. vragen over ant $\|$-conceptle,

12. klachten van dulzellgheld en/of corsulzen.

Aangezlen vanaf 1979 een minder anvangr lJk categor leänsysteem is gobrulkt voor de scoring van de patlëntproblemen is een directe vergeIIJking met op in tabel 4-1 gepresenteerde gegevens nlet mogellJk. Ten aanzllen wan de hooveelheld Ingeleverde Journals constateerde de planningsgroep, dat het belangrlJk was vast to houden aan het ultgangspunt, dat studenten hun bevindlingen vastleggen in een Journall, dat vervolgens als startpunt dlent voor een nabespreking, voor verdere besprekling in de onderwiJsgroep en voor Individuele leeractivitelten. Het maken van dergel IJke Journals vormt een essentleel onderdeel van de stage, maar de ervarlingen tljdens het erste reallsatlejar geven aan, dat dit nlet door alle betrokkenen als een vanzelfsprekendheld wordt beschouwd. Een aental maatregelen zlJh genomen om hier In verbeferlng to brengen.

TiJdens de introductleweok wordt ultvoerlg op de functle van de verslagllegging Ingegaan en wordt ook geoefend on de student vertrouwd te maken met hot journaal. 
In de besprekingen met de hulsarts-oplelders en in de didactlsche voorberelding van nleuwe oplelders wordt meer aandacht aan het belang van de verslaglegging en in het verlengde darrvan, de nabespreking. geschonken.

Daarnaast wordt de nadruk meer gelegd op een goede sprellding van klachten en op de zlinvol held wan het verslag voor verdere leeractivim telten. Aan de kwontiteitsels wordt op deze wljze cok on inhoudell IJke e is gekoppeld.

In tabel 9-1 zijin de aantallen Ingeleverde journals over en aantal stageperloden wergegeven *

Tabel 9-1: Gemiddelde aratallen ingeleverde Journaals per student in de perlode naj aar $1979+/ m$ voorl aar 1982 .

perlode

$$
\begin{aligned}
& \text { aantal } \\
& \text { studenten }
\end{aligned}
$$

26

21

$16 *$

29

naj ar 1981

voorJ aar 1982 gemiddeld aan-

tal Journaals

99

108

103

106

111

115 cantal weken in

de praktljk

* gegevens van acht studenten ontbreken.

Rekenling houdend met de verkorting wan de stage met oen week wanef het najar 1990, kam een stijgende $11 \mathrm{jn}$ in het aantal ingeleverde journeals geconstateerd worden. De stljging in het studlejaar 1981/82 is warschljnlijk mede het gevolg van en laatste maatregel an de verslaglegging beter te laten functloneren. Vanaf dat tljdstip worden namellijk alle journals cok van commentaar voorzlen door de hulsartsbegelelder, liets wat tot dan toe nlet systanatl sch werd gedaan. ult de verslagen van de hulsarts-begelleilders kan voorts geconcludeerd worden, dat de kwall telt van de Ingeleverde journatils tot tevredenheld stemt. ZIJ rapporteren, dat met name de systematlek van de verslagleggling is verbeterd. 
Toch blift het gemlddelde total antal journaals achter bij het geplande aantal van 3 patlënten per dagdeel in de praktljk. Een gemiddeld aantal van 125-150 journaals zou op die basis verwacht mogen worden.

In hoofdstuk 4 werd geslgnaleerd, dat studenten tijdens het studiejar $1978 / 79$ nlet van al hun zelfstandige contacten met patienten een Journeal maken. Vanaf het voorJaar 1980 is aan de studenten gevraagd en schatting to geven hoeveel patiönten zl』gemiddeld per week tijdens de tweede helft van de stage zelfstandig zien. De antwoorden zijn weergegeven in tiguur 9-1.

Flguur 9-1: Aantal zell fstandilge student-patlëntcontacten per week gedurende de tweede helft van de stage (volgens schottingen van de studenten).

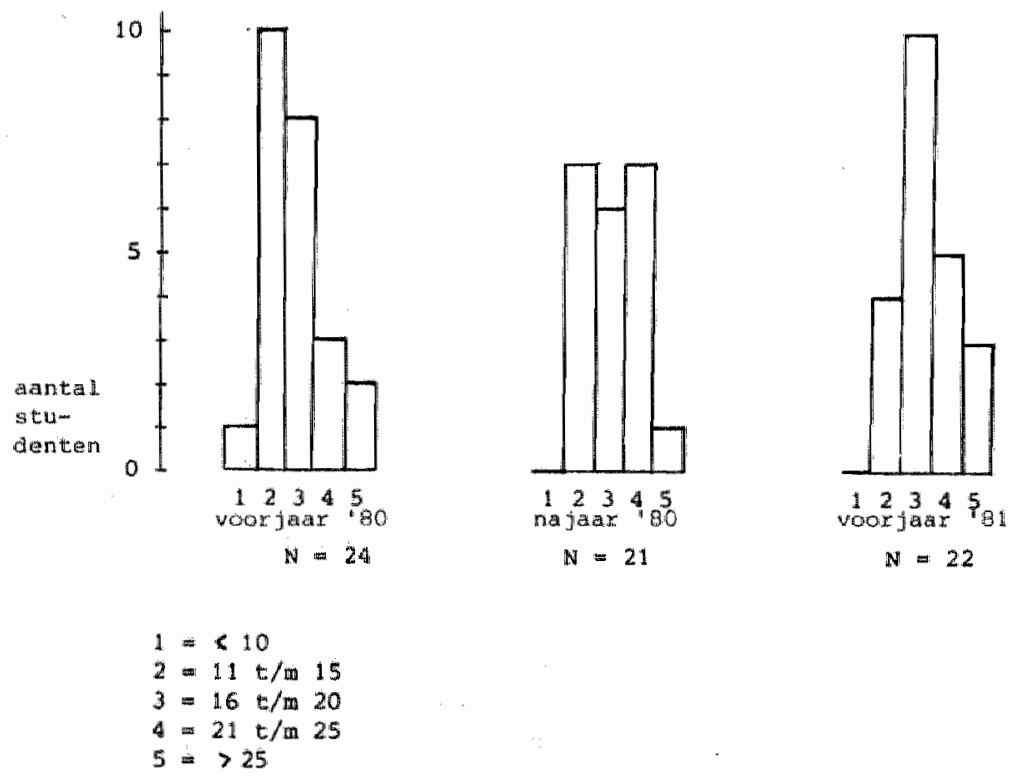


Ult de eard van de vraagstelling is nlet direct te berekenen hoevel patienten gedurende de gehele stageperlode gezlan worden. Woorzlchtlg geschat llgt het vermoedell Jke totallaantal $50 \%$ hoger dan het aantal patlëntcontacten, waarvan een journaal gemaakt is. Een zekere discrepantie tussen verwachtingen en feltell lke ultkomsten is op zilch nlet zorgwekkend. De hler geslgnaleerde verschll len zlJh echter omvangrljk. De andacht van de stage-organisatoren voor het opheffen van deze discrepantle is zeker wan belang, aangezien de aard en de kwalltelt van de activitelten, die niet door studenten worden gerapporteerd, geen aantoonbare relatle met de doelstell ingen van de stage hebben.

Afzonder lljke vermelling in deze paragraaf verdlent het gebrulk van de zogenaamde gezinsstatus. In hoofdstuk 4 is hlerover opgemerkt dat in $1978 / 79$ slechts één student een dergellljke status heeft gemaekt. Het volstrekt niet functloneren van dit stage-onderdeel kan moellijk verkllaard worden uit een gebrek aan zlnvalheld van een dergelljke activitellt. Julst de gezinsstatus makt het mogelljk medlsche klachten te plaatsen tegen de achtergrond van angevings- en gezlnsinvloeden. In een aantal bultenlandse currlcula neemt een dergelifke actlvitelt dan cok eon centrale plaats in als kennlsmaking met de oerstellinsgezondheldszorg (b.v. Southampton, North Carollna, McMaster). In de opeenvalgende stageperloden is met wisselend succes getracht dit stage onderdeel beter tot zlJn recht te laten komen. Daarblj was de vasthoudendheld van de hulsarts-begelelder warschljmlljk oen bepalende factor.

De stage-organisatoren rapporteren dat studenten, die de activitelt wel ondernemen, dit als een zinvol onderdeel van hun stage beschoumen. Gezien het gegeven, dat op vrljblljvende basls onvoldoende aandacht aan dit onderdeel wordt geschonken, hebben de stage-organ I satoren het waken ven gen gezinsstatus in het najaar 1982 tot verpllicht onderdeel $v$ an het stageprograma gemaakt. Het booogde effect werd zonder protest van studentzljde berelkt.

De conclusle ult deze gang wan zaken is, dat plaatsing in de hulsartspraktljk geenszlns garandeert, dat de student aandacht besteedt aan de bredere context van de eerstel IJ nsgezondhelidszorg *

9.5. De onderwijsgroepsbljeenkonsten.

Het order beschreven onderscheld tussen patlëntbesprekingen en thema- 
besprekingen is door de planningsgroep gehandhaafd. On organisator Ische redenen is na verloop van tlja besloten éen dubbele sessle per week in plaats van twe of zonder lljke bljeenkomsten te houden. De wardering van de studenten voor de groepsb ljeenkomsten is weergegeven in tabel 9-2. Het wisselend beeld van deze warderingsgegevens Is ven verschljnsel, dat zlch ook in de gegevens omtrent groepsonderwijs in andere studlejaren woordoet (GIJselaers, 1982). Het totaalbeeld geeft aan, dat studenten gematigd positlef over de zinvolheld yan de groepsbiljeenkomsten cordelen. Voorts oordeelt men vaak positlever over de patiëntbesprekingen dan over de themabijeenkomsten.

Tabel 9-2: Studentenoordeel over de zlnvolheld van groepsbljeenkomsten.

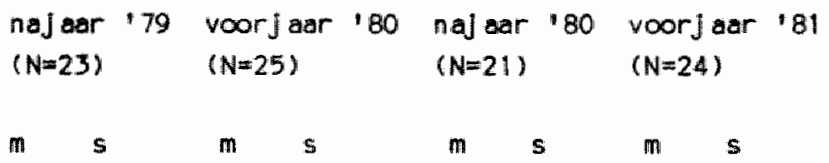

De patlëntgerlich-

to bijeenkomsten

vand lik zinvol

2.31 .0

$2.8 \quad 0.9$

$\begin{array}{llll}1.8 & 0.7 & 2.4 & 1.4\end{array}$

De themagerichte

bljeenkamsten

vond $\mid k z$ invol

$2.7 \quad 1.1$

$1.6 \quad 0.6$

$2.4 \quad 1.4$

$\begin{array}{ll}3.6 & 1.1\end{array}$

De groepsbiljenkansten vormden voor mid on ossentläle bilddrago an de stage $2.9 \quad 1.2$ $2.4 \quad 1.2$ $\begin{array}{llll}2.3 & 1.0 & 3.4 & 1.3\end{array}$

(antwoorden op een 5-puntsschal : $1=$ volledig eens, $5=$ volledig oneens.) 
De patiëntenbesprekingen hebben betrekking op de meest frequent voorkomende klachtencategorleän ult de Journats. Vrljwel noolt wordt bll dergel ljke bljeenkomsten en deskumdlge van en andere disclpline ultgenod ilig.

Uit de verslagen van de hulsarts-begelelders komt naar woren dat de meest gekozen onderwerpen voor de themabljeenkomsten zlJn: method isch werken, preventle van somat Ische flxatle, dlagnostische mogellukheden van de huisarts, de chronlsche patient, de elgen persoon als hulpverlener, farmacotheraple in de hulsartspraktlJk, zlekte als maatschappelljk verschiljnsel, alternatleve geneesmethoden en het patlenttenrecht. Dok blj de themabesprekingen is de aanezigheid van andere deskundlgen in de loop der jaren nlet zo gebrulkelljk, zoals corspronkelljk de bedoelling was. De belangrljkste verklarling voor deze ontwiklkelling vormt waarschljnlljk de versterking van de rol van de hulsarts-begelelder.

De hulsarts-begelelders hebben door hum ervarling beter zicht gekregen op de mogelljkheden van de stage vanult het perspectlef van de hulsartsgeneeskunde. ZiJ ziJn dan ook steeds beter in staat zelf invulling te geven aan de groepsbljeenkonsten: ze zijn vertrouwd met de problematlek, warmee studenten worstelen; ze kennen de opleldingsituatle en ze kuminen profiteren van hum elgen ervarling als hulsarts. Tegenover deze voor de huisartsgeneeskunde pasitleve ontwikkeling staat echter, dat hlerdoor een belangrlJk ultgangspunt van de stage, namelljk de Interdiscliplinalre opzet, minder tot haar recht kant. In paragraaf 9.9.2. zal hlerop verder worden Ingegaan.

9.6. De becordeling van de studenten.

In hoofdstuk 3 is reeds aangeduld, dat het examensysteem van de faculteit der geneeskunde een belangrll lke randvoorwaerde vormt woor de li.jze waarop binnen de stage becordellingen van studenten functioneren. De gestelde randvoorwarde, nameljk dat beoordel ingen tijdens de stage op geen enkele wijze van Invlaed zljn op besllssingen over de studlem voortgang, is in toenemende mate alls onwerkbaar en onwensel IJk beschouwd door de stage-organ isataren.

olt oordeel is gebaseerd op en antal problemen, die zlch hebben voorgedaen als gevolg van deze randvoorwarde:

1. het ontbreken van meetellende beoordelling lelide lin somilge gevallen tot een vrljblljwende houding van studenten ten aanzlen van de invulling van het stageprogramma. 
2. het slechte functioneren van enkele studenten in praktljksltuatles kon formeel nilet bljgestuurd worden, zowel tijdens als na de stage. Aanvamkellijk mocht informatle hlerover zelfs nllet beschlkbaar worden gasteld an examencomissles.

Ook In breder verband bleek de randwoorwaarde ongelukklge consequen* les te hebben. Zo kreeg het baslsartsexamen door het nilet in aanmerking nemen wan studleprestatles en functloneren tljdens de vooratgaande twee studiejaren het karakter van een hoge horde, terwiJl vanaf de start van de facultelt Juist het bellang van voortgangsevaluatle is bepleit.

Het zou binnen het kader van dit onderzoek te ver waeren on thet becordelinglsystem van de facultelt der geneeskunde gedetall leerd aan de orde te stellen. Woor de beoordellingsprablematlek binnen de stage is het echter van bellang to constateren, dat slinds 1979 in toenemende mate door studenten docenten geconcludeerd is, dat stagebeoordel ingen In enigerlel vorm en rol dienen te spellen blj het nemen van besillssingen over de studlevoortgang wan studentem. In en antal stappen heett die ontwlikkelling zlch dan cok daadwerkelljk voltrokken: aanvankel IJk konden stagebecordel Ingen op ver zoek wan studenten betrokken worden In het elndgesprek, dat deel ultmaakte van het basisartsexemen; vervolgens werden de stagebecordel ingen in het studentdossler opgenomen, zonder dat het gebrulk duldelljk geregeld was; tenslotte maken stage-beoordel Ingen vanaf september 1982 deel ult van het basilsartsexemen.

De stage-organisatoren hebben deze ontwikkeling niet passlef afgewacht. De pogingen on nader inhoud te geven aan de stage-becordelingen waren gerlicht op thet vinden van een goede manler om de hulsarts-opleiders bl] de becordeling in to schakelen, aangezllen de becordeling van het functioneren van de student In praktijksiltuaties In de stagebecordelling central dilent to staen.

In het studlejear $1979 / 80$ word getracht de gestructureerde observatle wan het student-patlënt-contact, zoals beschreven in paragraaf 5.3, hlervoor ls middel the benutten. De acceptatle hlervan door de hulsartsmoplelders bleak echter toch to llaig te zljn, zodat gezocht dlende to worden nar cen andere methode. Vanaf het studlejaar 1980/81 is geaxperlmenteerd met een aantal beoordelingscrlterla, dle in een gesprek tussen opllelder, begelelder en student tot en elindbeoordeling van de stage dient te leliden. Deze becordelingsvorm heeft zlch thans ontwlkkeld tot en becordell Ingsformuller. De hulserts-begelelder vult hlerop 
de beoordeling in, die in belangr IJke matie gobaseerd is op en el indbocordel ing sgesprek.

Buttem de praktlJk worden twe andere vormen van formatleve beoordeIling gebrulkt. Aan het beg in van de stage doet de student volledig consult met simulatlepatlënt. Dlt wordt op videoband opgenomen en nabesproken met de hulsarts-begelelder. De werschulving van deze becordeling naar het begin van de stage is vooral ingegeven door de behoefte van hulsarts-begelelders on enig inzlcht in het functioneren van studenten met patlënten te verkrijgen om op dle basis zijn begoleidersrol in het verlloop van de stage to kunnen vervullen. Voorts wordt vilf fmaal gedurende de stage pen papleren patlëntenprobleem als toets an de studenten voorgelegd. Deze toetsworm is antwikkeld door de Graaf \& Galesloot (1981). In valldatle-onderzook is komen vast te staan, dat de toetsresultaten hoog correleren met de competentle-factor van het in paragraaf 5.3.2. beschreven beoordeIIngsinstrument (de Graaf \& Galesloot, 1982).

Hoewel de stagebecordelingen, zoals vermeld, tot het studiejaar 1982/83 geen formele plaats in de examenprocedures Innamen, kan men op basis van de thans gehanteerde oriterla aan de hand van aanwezlg becordel ingsmaterlaal de stageresultaten alsnog onzetten in een globale beoordeling in de categorleën: voldoende, twijfellachtig onvoldoende.

Aan de betreffende hulsarts-begeleiders is gevraagd dit to doen. De resultaten zijn weergegeven in tabel 9-3.

Tabel 9-3: Samenvattende stagebeoordellingen voor de studenten in $1979 / 80$ en 1980/81 volgens in 1982 geformulerde criterla.

perlode goed twiffelachtig onvoldoende

naj aar $79(n=24)$

voorJ aar $180(n=25)$

noj aar $180(n=21)$ 
De clJ fars geven alan, dat het antal problemstudenten geleldellyk affnemt. De corzak darvan is nlet eenduldig te bepalen: enerzljids kan dit het gewolg zijn van verscherpte selectio woorafgaande aan de stage, ander $21 / d s$ van betere begelelding tljdens de stage.

op zich is het echter van belang, dat studenten in overgrote meerderhoid in steat blljken op actleve wjze in de hulsartspraktijk te particlperen.

9.7. De hulsarts-oplelders.

Elnd 1982 bedroeg het asntal hulsartsen, dat de didactische tralnilng had gevolgd ongeveer 100. Dit Impllceert dat de activitelten op het gebled van de werving en voorberelding van hulsarts-oplelders met dezel tide Intensitelt is voortgezet, als tljdens de aanloopperlade het geval was. Aangezlen het antal studenten, dat Jaarlljks de stage loopt sllechts geleldelljk gestegen is tot ongeveer 60 studenten in het studlejaar $1982 / 83$ zou men genelgd zijn to concluderen, dat er thans sprake is van een ruim aanbod van opllelders. Dit is echter niet het geval. Al lereerst bll Jken de meeste hulsarts-oplelders slechts ëérmaal per Jaar bereld als oplelder voor een vijfdejaarsstudent op to treden. Daarnaast vormen andere actlvitelten van de facultelt der geneeskunde ten aanzlen van de hulsartsen een concurrentle, dle het aantal beschlkbare oplelders verklelnt. Met name de beroepsopleilding tot huisarts, maar cok de deelname wan hulsartsen aan gezondheldszorg- en onderzceksprojecten impliceren, dat niet alle opleiders feltelluk beschilkbar ziJn voor deze stage. Tenslotte is er cok enig verloop In het opleldersbestand door praktl Jkbeëlndigling.

De concluslle, dle ult deze stand van zaken getrokken kan worden Is, dat bij de voorzlene verdubbeling van het antal studenten in de naasto toekomst onvoldoende oplelders beschikbar zullen zijn, wanneer het tolnutoe gevoerde belleld binnen het huldlge wervilingsgebled voortgezet wordt. In paragraaf 9.9.1. over de toekamstige ontwikkellingen zal hllerop worden teruggekomen *

In peragraaf 4.5 is reeds geconcludeerd, dat het stage-model in grote IIjnen ultwoerbaar blljkt in de hulsartspraktljk. Niettemin bleok in het erste real isatiejar, dat nlet alle stageplatsen in even grote mate geschlkt waren voor het optlimaal verlopen van de stage. 
De hlervoor geschetste schaorste aan oplelalingsplaatsen betekent, dat noodzakellJk geachte verbeter Ingen on veranderlingen in het algemeen nouwell IJks tot stand gebracht kunnen worden door scherpere selectle van oplellers, maar voornamelljk door het besteden van aandacht on energle aan de beschlkbare oplelders. Het zou onjulst ziln, wanneer ult de voorgaande 2 In geconcludeerd wordt, dat de facultelt blj gebrek an keuze aandacht an de oplelders besteedt. Dat is goenszins het geval. Het bevorderen van de blljvende betrokkenheld van de oplelders blj de stage en het geven van feedback op het functloneren als oplelder kunnen beschouwd worden als normale onderwlj skund lge randvoorwarden voor het goed functloneren van een stageprogramm. Het onderhouden van contacten past voorts in het facultalr beleid, dat gerlcht is op versterking vian de eerstel iJnsgezondheldszorg.

De aandacht voor hulsarts-oplelders wloelt ook voort ult de ontwlkkeling, die de roll van de oplelder heeft doorgemakt. In de allereerste schetsen voor de stage-opzet had de hulsarts-opleider een vrij boperkte nol: hilj verleent de student toegang tot de praktljk en tot pa* lënten. In de verdere ultwerklng heeft de oplelder ook een antal duidelljke docentfuncties gekregen. De hulsarts-oplelder observeert, becomentarleert, adviseert en stlmuleert de student tot reflectle op diens handelen. De ervaringen in de afgelopen Jaren hebben ultgewezen, dat deze taken een wezenlifk onderdeel vam het stege-programa vormen. De hulsarts is over het algemeen echter nlet opgeleld voor het geven van onderwijs en hilj wordt gevraagd mee te werken aen oen opleldingsprograma, dat sterk afwlJkt wan zlJm elgen vroegere oplelding. Eion eemallge workshop van 2 degen, warln de hulsarts op actleve wlJze vertrouwd wordt gemaakt met zijn rol als oplelder, kan nlet meer zijin dan een eerste kennlsmaklng, dle als zodanig nlet voldoende is.

De behoefte ean begelelding van de oplelders Is overlgens eell wens, dle herhaalde malen door de oplleiders zelf is verwoord, hetgeen als en willing van de Interesse on betrokkenheld van hulsartsen blj de stage kan worden beschouwd. Aanvankelljk zljn de contacten vooral gobonden geweest aan de stage-perloden.

De contacten In groepsverband met de hulsarts-oplelders, dle ander de hoede staan wan een hulsarts-begelelder namen hlerblj een centrale plaats In. Doordat steeds nleuwe oplelders mee glngen doen had de onderllinge ultwisselling van ervarlingen een duldelijke functle. Nu het merendeel van de opleiders echter reeds een aental malan als zodanig Is opgetreden is het rendement van dergelljke bljeenkomsten verm Inderd. Met Ingang van het studlejar 1982/83 wordt daeram docententralnIngsprograma georganlseerd, dat bestaat ult een aantal bljeen- 
komsten gesprelld over het studiejar. Op vrljulllilge basis kunnen hulsarts-oplolders hierean deel nemen, ongeacht of zlj op dat ogenblik oen student als staglare in de praktljk hebben.

De Individue contacten $+1 j$ dens de stageperloden met de hulsarts-begelelder Zlljn gehandhaafd op twee bezoeken per stage: eenmaal om een nabesprekling blj to wonen en de gang van zeken te bespreken en eenmaal aan het ind van de stage. Dit laatste gesprek heeft het karakter van on becordel ingsgesprek woor de student.

9.8. Het kostenaspect.

Het praktisch medisch onderwils in de hulsartspraktijk, zoals dat de afgelopen $J$ aren vorm heeft gekregen, is te beschouwen als een vorm van bulten de facultelt plaatsvindend onderwljs, vergell ljkbaar met het extern onderwils dat in geeffill leerde zlekenhulzen verzorgd wordt. Dle parallel is overigens all getrokken in het Tweede Rapport van de Affillatle-advlescomlssle inzake de afflllatle ven unlversitelten (facultellten der geneeskunde) met niet-academ Ische zlekenhulzen (1974). om enlg ldee te krljgen van de kosten van het praktisch medlsch onderwijs in hulsartspraktijk is getracht de kosten daarvan op $\mathrm{J}$ aarbasis per student to vergelljken met de kosten van een stage in een geaffiIleerd zlekenhuls op $J$ aarbasis ( $z$ le tabel 9-4). Daarbif is onderscheld genaakt tussen de kostenvergoedingen aan de stageplaats en de overlge kosten gembakt door de facultelt. Als basis is genomen het jaar 1982 en com de vergelljking wat te vergemakkelljken zijn de kosten berekend voor perlode van 48 weken, ziljnde 4 PNoH-stageperloden. Het is nlet mogelljk al le kosten direct to bepalen, zodat in een aantal govallen schattingen zijn opgenomen. Voor de goede orde zll vermeld, dat het hier nlet gaat on een integrale berekening van alle kosten, dle ten behoeve van het onderwijs aan studenten gemaakt worden. Allerlel kosten, dle warschljnlljk gelljkelljk an studenten in de hulsartspraktljk of in het zlekenhuls kunnen worden toebedeeld zijn bulten beschouwling gelaten. Hlerblj valt bljvoorbeold te denken aun kosten van de onderwijsadministratle, het examensysteem en blbllotheekvoorzleningen. 
Tabel 9-4: Kosten afflllatle-onderwlJs op Jaarbasis (48 waken) per stageplaets.

Kosten stageplaats in affll latiezlekenhuis.

A. Vergoedilngen aran stagep laats:

docentvergoed ing $1.20 \times f 1.1 .4 .400 \times 48 / 52=$

f1. $15 \cdot 950,-$

(conform contract)

bi Jdrage overheadkosten $4.9 .500 \times 48 / 52=$

11. $8.750,-$

(conform contract)

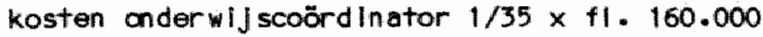

$\times 48 / 52$ (conform contract)

11. $4 \cdot 200,-$

B. Kosten facultelt:

contact met stageplaats

geschat 10 uur $\mathrm{fl}$. 100 , -

f1. $1.000,--$

afflllatle-over leg 2 uur à $f$. $100,-$ (geschat) fl. 200,--

relskosten docenten geschat $1 / 35 \times 5000$ fl. $0,50 \mathrm{f}$. $100,-$

TOTAAL

f1. $30.200,-$

Kosten stageplaats PMCH.

A. Vergoedingen aan stagep laats:

docentenver goed ing $44 \times f 1.300,-$

f1. $13.200,--$

(conform contract)

B. Kosten facultelt:

anderwilstifd hulsarts-begel lders

$1 / 10 \times .5 \times+1.138 .000 \times 48 / 52$

f1. $6.350,-$

stagecoördinatle $4 / 60 \times .8 \times f 1.138 .000 \times 48 / 52+1.6 .800,--$

docenttll Jd overlge bll Jdragen $4 \times$ i uur à $11.100,--11$. 400, --

relskosten hulsarts-begelelders

$4 \times 2 \times 50 \mathrm{~km} \cdot \times+1 \cdot 0,50$

f1. $\quad 200,--$

bljdrage in studentrelskasten

$4 / 60 \times+1.15 .000,-$

f1. $1.000,=$

TOTAAL

11. $27.950,-$ 
In totaal ziljn de kosten op Jaarbasls voor het PMOH woor zover het de reallsatle van de stage betreft, lets lager dan woor een stageplaats. In een geaffill leerd zlekenhulls. Voorts dlent opgenerkt to worden, dat de facultelt een grotere facultalre Inbreng In de gang van zaken bl] de stages in geaffll leerde zlekenhulzen wenselljk acht. Wanneer dle Inbreng in 1982 gereallseeerd zou zljm in de vorm van éen full-time staflld, dan zouden de kosten per, stageplagts met ongeveer $11.3 .500,-$ stilgen.

Het problem voor de facultelt blj deze kostenvergell Ijking schullt echter In het gegeven, dat kositenvergoeding aan de stageplauts en kosten "gemsalkt door de facultelt geschelden gof Inanclerd worden en niet ultwisselbaer ziJn. Met andere woorden, de facultelt wordt nlet financleel gecompenseard voor haar extra ult tgaven ten behoeve vam het praktisch medisch onderwl]s in de hulsartspraktljk.

Naist de hlerboven gemakte kostenberekenling is het vian bellang erop te wijzen, dat met de wervling en onderwlJ skundlge scholing van hulsartsoplelders nog aanzlemlijke kosten gemoelld zijn. Wanneer men de gernwesteerde staftijd in de werving, de relskosten en de kosten van een tweedaagse cursus in agenschouw neent dan kost de werving van één nleuwe opleildingsplaats ongeveer $f 1.2 .000,-$.

Dok deze kasten arukken in belangrljke mate op het facultalre budget en zullen de komende Jaren, gezlen de noodzakellJke ultbreliding van het antal stageplatsen noodzakel IJk bl IJven.

Aangezlen de facultelt der geneeskunde geconfronteerd wordt met een sterk krimpend middelenperspectlef, zowel ten anzlen van personele middelen is ten auzlen van over lge kostenscorten is het van groot belang, dat de In de komende Jaren nog toenemende discrepantio tussen de toowlJzIng van middelen an de facultelt voor dit onderwlls en de gedene ultgaven wordt opgeheven.

9.9. Hat praktlsch medisch onderwlJs in de huisartspraktijk in de toekonst.

De doellstelling van deze paragraat is an op grond van de ervarlngen en de betrokkenheld wan onder zoeker blj het praktisch medlsch onderwijs in de hullsartspraktijk een antal aanbevellingen te doen die van 
belang kunnen ziln woor de toekomstlge ontwikkelling van het praktisch medlschil onderwijs in de hulsartspraktljk.

Ultgangspunt voor deze beschouwing is de constaterling, dat de stage in de hulsartsprakt ljk en geaccepteerd onderdeel van het medisch currlculum varmt. Studenten achten deze stage een bellangrljk onderdeel van hun oplelding. Zlj komen tljdens hum stage in aanrakling met patlëntenproblematlek, dle zij niet in een zlekenhulssetting tegenkomen ze maken op unleke wijze kennis met de werkwljze van de hulsarts.

Het continueren en verder ontwlkkelen van deze stage ligt dan ook voor de hand. DaarblJ zull en echter een aantal knelpunten en tekortkomingen moeten worden owerwonnen. Het belangrljkste knelpunt vormt de beschlkbaarheld van voldoende stageplaatsen on vanaf $1986 \mathrm{j}$ aarl ljks ongeveer 130 studenten in stat to stellen deze stage to volgen. De belangr lJkste tekortkoming vormt, naar het cordeel van de onderzoeker, het reletieve Isolement van de stage, zowel ten opzlchte van het totale terrein van de eerstellijnsgezondheldszorg, als ten opzlchte wan andere academ ische discliplines bInnen de facultelt. Terzljde kan worden opgemerkt, dat dit probleem zlch blj de andere stages in het vijfde en zesde studiejar evenzeer voordoet.

Hieronder zullien deze problemen achtereenvolgens besproken worden.

9.9.1. De beschlkbarheld van stageplaatsen.

Het wervingsgebled van de facultelt cmvat thans de provincle Limburg ten zulden van venlo. In dit gebled zlJn ongeveer 335 hulsartsen werkzaam, warvan, zoals cerder vermeld ongeveer 100 één of meermalen als huisarts-opleider ten behoeve van de stage zlJn opgetreden. Met dit oplelderspotentleel bl ijkt het op dit ogenblik mogelljk amstreeks 65 studenten jaarlljks een stageplaats to bezorgen. Vanaf 1986 zullon echter Jaar llJks 130 stageplaatsen beschllkbaar moeten 2 lJn. Wanneer op dezelf fe basis gewerkt zou worden betekent dit, dat nog 80-100 extra oplelders gevonden dlenen te worden. Ook wanneer men aanneent, dat door praktijkverklelining het aantal hullsartsen nog zal toenemen, zal het antal opleldingsplaatsen binnen het huldige wervingsgebled te klein blljken. Niet ledere huisarts zal er limers ok In de toekonst voor volen als oplelder te functioneren; daarnaast beschikt groot aantal anderen niet over de rulmtell ljke voorzleningen om adeculuat als. oplelider te functioneren; tenslotte zulllen or ook in de toekonst huls- 
artspraktijken bllljuen, dle door de facultelt minder geschlkt worden bevonden als stagepllaats.

Een betrekkelljk envoudlige mogellijkheld an dit problem het hoofd to bleden zou het drastisch Inkorten van de stage kunnen zijn; wanneer de stage tot ongeveer de helft wan de tljd wordt teruggebracht is het huldige aantal opleiders ongetwljfeld voldoende. Hoowel or voor geen enkel onderwljsprogram slultende argumentatie is te geven om de duur ervan te rechtwaardigen, zijn er wel en aantal overwegingen te noemen, waarom dergel ljke handelswijze nlet verstandig is.

De in hoofdstuk 2 gencemde hoofdargumenten voor stage in de hulsartspraktijk, namel ljk de onbegrensde varlëtelt van klachten, het gegeven dat een groot deel van de patlëntenklachten nlett tot een verwijzing leldt (en dus nlet in een andere setting gezlen kan worden) en de speclfleke werkwljze van de hulsarts verelsen dat studenten gerulme tijd in de hulsartspraktijk verblijuen. In langere stage is het voar studenten nlet alleen mogelijk een grotere varlëtelt van patlënten te zlen, maar cok dezelfde patiënt meerdere keren, waardoor hij een beter inzlcht in het zlekteverloop en de klachtbeleving van de patlënt kan verwerven. Daarnaast is cok van belang, dat hlj veelvuldig In de gelegenheld is belangrijke onderscheldingen als normaal-abnormaal, ernstig-niet-ernstig to maken.

Voorts kan erop gewezen worden, dat de eerstelljnsgezondheldszorg een steeds belangriJker plaats inneemt in het Nederl andse gezondheldszorgbeleld; voor toekomstige beroepsbecefenaren in de gezondheldszorg is het daarom belangriJk een meer den marginale practische introductle in dit veld to krlJgen gedurende hun basisoplelding.

Tenslotte kan het consumentenoordeel genoend worden: studenten vinden de stage $z$ lnvol, en belangr $\mid J k$ en goed georganliseerd curr Icul umonderdeel en het overgrote deel van de studenten acht de stage nilet te lang.

Wanneer we orvan ultgaan, dat het inkorten van de stage nlet zinvol 1s, dan blijven in princlpe twee mogelljkheden over on het drelgend tekort oan opleiders het hoald te bleden.

De eerste mogelljkheld is ultbrelding van het wervingsgebled. Daarbilj is $Z-0$ Brabant en aantrekkell Ijker mogelljkheid dan het noorden van de provincle Limburg, aangezlen de reistljd naar Noord-Limburg langer is vanwege de slechte verblndingen tussen Zuld- en Noord-Llmburg. Uitbreiding van het opleldingsgebled betekent in leder geval een anzlenIIJke extra tijdsbelasting voor studenten en huisartsbegelellders en brengt voor belde groepen ook extra relskosten met zich mee. 
Een tweede mogelljkhell houdt in het intenslever benutten van opleldingspraktilken. Wanneer het huldige oplelderspotentleel, dat werkzaam is In ongeveer 75 hulsartspraktiJken contlnu een student in de praktijk zou nemen, dan zou het capaciteltsprobleen opgelost zljh.

Al eerder werd er echter op gewezen, dat de oplelders hun toak verrlchten naast hun volledige dagtaak als hulsarts. Het is weinig reoel te veronderstellen, dat onder die condllties hullsartsen in grote getale bereid zijn een dergelljke oplelldingstak op zlch te nemen.

Wil een dergelljke mogelljkheid cak reallseerbaar worden, dan zal de opleldingstaak een Integraal bestanddeel moeten gean vormen van de taak van de deelnemende hulsartsen. Dat is alleen mogelljk wanneer een langlopende wederzljdse verplichting tussen oplelder en facultelt bestat. In de medische opleldingen in Nederland zijh er ten aanzlen van het praktisch onderwlys in kl Inische speclallismen twee grondvormen voor dergelljke langlopende verpllichtingen, dle cok ten aanzien van de stages in de hulsartspraktljk toegepast zouden kunnen worden, namelijk academ Isering en atfillatle.

Academiser Ing impllceert, dat onderwijs- en onder zoekstaken ultgevoerd worden onder directe verantwoordelljkheld van de facultelt der geneeskunde, hetgeen meestal resulteert in dienstverband met de facultelt. Deze constructle Impllceert tevens, dat de facultelt een zokere verantwoordel lJkhelld a a gt voor de patlëntenzorg blinnen de geacadem lseerde setting.

Afflliatle betekent, dat de unlversiteit (In casu de faculteit der geneeskunde) ean langlopende samenwerk Ingsovereenkomst met en gezondheidszorginstelling sluit, waarbij deze instelling, onder behoud van zelfstandighell, een aantal onderwijstaken werrlicht en voorts betrokken kan zijn bij onderzoeks- en gezondheldszorgprojecten van de facultellt.

In de nota "Academ Iser Ing Eerste LIJ n" (1981) wordt een schets gegeven van het beleid, dat de faculteit der geneeskunde op het gebled van de academiser ing van hu isartspraktijken denkt to voeren in de naaste toekomst. Opvallend daarbly is, dat het piractisch medisch onderwljs slechts in geringe mate zou proflteren van deze ontwikkelling: voorzlen wordt dat in de toekomst $20 \%$ van de studenten hun stage in een geacedem Iseerde praktljk zullen wolgen. Onduldelljk blljft, of hler pragmatische keuze voor een percentage wordt gedaan, dan wel een princlplele beleldskeuze. Wanneer dit beleld daadwerkelljk ultgevoerd wordt, dan zal slechts in ger Inge mate tegenoet worden gekomen aen het gesignaleerde tekort an opleldingsplaatsen, zeker wanneer men uiltgat van de realistische veronderstelling, dat de te academ Iseren praktij- 
ken voor an bellangr ljk devil zullon bestaen ult thans reeds functlonerende opleidingspraktljken.

De andere mogelljkheld tot intenslever gebrulk van opleldingspraktijken llgt in het afslulten van langlopende afflllatlecontracten, warblJ de hulsarts-oplelder in princlpe gedurende het gehele laar oen student in zijn praktlljk opneent.

Aangezlem de huldige werkwljze met contracten voor steeds éen perlode all nlet lellien tot een contlnue deelmame van tweameal per Jaar aan dit stageprograma, mag men wan het anbleden van en langlopend contract op de huldlige voorwarden geen hoge verwachtingen hebben. In het geval van langlopende contracten $\|$ igt het echter voor de hand de systematlek van de affll latlegeldtoew Ijzing aan de zlekenhulzen cok in zoverre te volgen, dat naast een vergoeding voor de docenturen ook een vergceding van andere kosten en eventueel bijdragen voor infrastructurele voorzlenilingen mogelljk worden.

Zowel het academiseringsmodel als het affillatlemodel zullen ongetwiJfeld lelden tot hogere vergoedingen aan de oplelders dan thans het ge$\mathrm{val}$ is. Een dergelljke ontwlkkeling $11 \mathrm{Jkt}$ al leem verdedlgbaar, wanneer deze praktljken ultgroelen tot volwardlge opleldingsplaatsen, wardoor grote tljdsbelasting van hulsarts-begelelders en de stagecoôrdinator relatlef kan afnemen:

Naar onze menling is de weg van afflllatle en/of academisering onontkoombaar on de organlsatorlische én inhoudel ljke kwetsbaarhelid van de stage lin de hulsartspraktljk te verm Inderen. Deze keuze houdt over lgens nlet in, dat ultbrelding van het wervingsgebled niet inodig zou zljn; nast ongever 35 praktljken die blj de afflliatle/academlseringsvarlant nodlg zIJn voor het PMOH, zIJn voor al lerlell kortere contacten met de hulsartspraktijk on voor de hulsartsoplelding relatles met en groot aantal hulsartspraktljken onontbeer l ljk.

9.9.2. Praktisch medisch onderwlJs in de hulsartspraktljk of stage hulsartsgeneeskunde?

In de naamgeviling an stage is wanaf het begin centraal gesteld, dat het spireken met on onderzoeken van patlenten blnnen de settling van de hulsartspiraktljk als belangrljkste actlwitelt voor de student wordt gezlen: 
De centrale doelstelling van deze actlultelten is het verwerven van kennls, vaardlgheden en attltuden, dle van belang $z$ ljn voor adequate zorgverlenling in de eerstellijn.

Een grondilge introductle in de werkw ljze vam de hulsarts is oen belangrlJke Inval shoek blj het reallseren van deze doelstelling. Onderwijs bereildt studenten achter voor op en bercep, dat In de toekonst ultgeoefend dlent to worden. Dat Impllceert, dat goed onderwljs prakHIJk-overstljgend dlent to zljn: nlet alleen datgene wat een hulsarts nu doet, maar ook datgene wat in de eerstelljnsgezondheldszorg zou kunnem, verdlent de aandacht van studenten.

In het stage-ontwerp is het bevorderen van de meerwarde van de stage met name zlchtbaar in het aangeven van thema's voor nlet-klachtger lchte bespreklingen, In de mogelijkheden on andere deskundigen blj het groepsonderwijs te betrekken en in aanbevelingen on tijdens het verblljf in de praktljk aandacht te besteden aan samenwerkingsactivitelten, met name in de eerstel ijnsgezondheldszorg.

ult de voorafgaande hoofdstukken kan worden opgemiakt, dat julst deze onderdelen wan het stage-programma moellijk reall seerbaar blljken. Wat betreft de aandacht voor sanenwerk Ingsrelatles in de hulsartsprakt ljk kan dit deels teruggevoerd worden op de praktljksltuatle, waarlin de student geplaatst wordt: In het overgrote deel van de opleldingspraktljken functloneren samenwerklngsverbanden nlet op een zodanlge manler, dat studenten or op een concrete manler me geconfronteerd worden. Een mogel IJkheld on hlerln verbetering to brengen zou kunnen zilJn het direct betrekken van andere disclplines blj de stage-opzet, wardoor men wat dit betreft minder afhankelijk is van het inlitlatlef van de hulsarts-oplelder. De overlge genoemde zwakheden IIggen aan de kant ven de Invulling door de onderwijsgroepen wan hun programma. Studenten billjken niet "vanzelf" toe te komen aan de mogelljkheden, dle blinnen de stage-opzet geboden worden om over de grenzen van het hulsarts-patllënt-contact heen te kljken, en voor zover ze dat wel doen, blljut dit voornamelljk en activltelt van de onderwljsgroep met de hulsarts-begelelder. Door deze gang van zaken blljft de inbreng van andere dllscip ll mes dan de hulisartsgeneeskunde voornamell ljk beperkt tot de Introduct lewek.

Hoewel de hulsartsgeneeskunde als disclpline ongetwilj feld en centrale pllats toekant in de discussle over en de reflectle op de mogel IJkheden van de geneeskunde in de cersteliJnsgezondheldszorg, kan gesteld worden, dat de wilsselwerklng met andere disciplines onontbeerillk IIs an on de prakt jk van de toekomst gericht stageprogramma te ver- 
zorgen. Het doorbreken van deze situatle is een belangr ljke taak woor de toekonst, dle van de kant van de stage-organlsatoren dlent in te houden het scheppen wan duldelljke mogellukheden on anderen bly de uitwoerling van de stage te betrekken en die woor andere disciplines Inhoudt en grotere betrokkenheld bll de stage.

Naar on ze mening zou de inbreng van andere dlscipll ines dienen the worden gestructureerd rond de ervaringen, die studenten in de hullsartspraktijk opdoen. Gezamenll.jke besprekingen rond de journaals zljn hlerblj ben belangrlJk mididel. Daarnaast zouden studenten méer gegevens In de praktljk dlenen te verzamelen, dle verder gaan dan het consult met éen patlënt: gegevens over Indlcatlestelling, verwijspatronen, gezinssituaties, leefmll leu, kunnen belangrljke aanknoplingspunten vormen voor de discussle over plaats en bellang van de eerstell Insgozond he ldszorg.

Aangezlen de korte historle van deze stage heeft uitgewezen, dat studenten het dlirecte contact met de patient een voldoende stlmulus achten on 12 weken zinvol to besteden, kan de vrljulijvendheld on ook nog aan andere doelstellingen en mogelijkheden aandacht te besteden all laen doorbroken worden, wanneer deze activitelten in de elndtermen van de stage tot ultdrukking komen.

Wanneer cen van de centrale doelstellingen, geformuleerd in de Baslsfllosof le van de Achtste Medische Facultelt (MFM, 1972), namelijk dat de medische facultelt en het medisch wetenschappellik onderwijs hun doelstellingen aan de gezondheldszorg dienen te ontlenen, colk in de naaste toekomst maatgevend zal blljven woor het belleld van de facultelt der geneeskunde in Maastrlcht, dan is de verdere ontwikkelling van het Praktisch Medisch. Onderwijs in de Hulsartspraktijk van grote betekenis.

Het overheldsbeleld ten aanzlen van de gezondheldszorg is gerlcht op het Indamen van de zlekenhulszorg door het voeren van een restrictief belleld door middel van beddenreductle. Ten onrechte wordt dlt beleid overigens gepresenteerd als "versterking van de eerstellinsgezondheldszorg". Wanneer deze ontwlkkeling zlich voortzet, zal ean takverzwaring wan de erstelljusgezondheldszorg optreden, warop in de oplelding geantlclpeerd dlent to worden. Een verschuiving van het accent In praktisch medlsche oplalding naar de settling, war in de patlenten zlch bevinden, In cesu de eerstelijnsgezondheldszorg, is dan een log I sche ontw I kel Ing.

Een goede voorberelding op de toekomstige tak van artsen in de Neder- 
landse gezondheldszorg kan echter alleen plaatswinden, wanneer naast hulsartsen cok andere discipllines in de facultelt hun onderwijsinspanningen op deze ontwllkelling afstellen.

De facultelt der geneeskunde van de Rilksuniversitelt Limburg hoeft door de ervaring met het Praktlsch Medlsch Onderwijs in de Hulsartspraktljk én door de rvaring met interdisciplinaire werkwljzen ean uitstekend uitgangspunt om het onderwijsprograma met succes aan to passen aan de zlch wijzigende omstandigheden in de gezondheldszorg.

In die verdere ontwikkelling vam het Praktlsch Medisch Onderwljs in de Hulsartspraktljk past cok de continuering van onderwljskundlg onderzoek. Dat onderzoek zou zlch dan vooral dlenen te rlchten op de betekenls, dle het spreken met en onderzoeken van patlënten heeft voor het verwerven van kennls en vaardigheden en het ontwlkkelen van de attltude van de toekomstige arts. 


\section{Summary}

Th1s dissertation focuses on the design and aluation of the threemonth attachment in general practice implemented by the medical faculty at Maastricht. Speclal emphasis has been put on the development of the attachment programe, the quallty of reallzatlon achleved during the fllist year of operation, and the programme's refinement in subseqvent years.

In chapter 1 the research is viewed against the background of trends In educational research Into Higher Education. Also the attachment concepts are entered into and the role of this practical training in medical education.

Chapter 2 describes the original design of the attachment. The positIon accorded to It In the curriculum is elucidated, as is the setting in which its structuring has taken place. Furthermore, the most important elements of the attachment are dealt with successively. The major polnts are outl Ined in some more detall below.

In the Netherllands, fam Ily mediclne or general practice tradltionally plays an important role in the health care system under the influence of legal and insurance policies. On a population of about $14 \mathrm{~m}$ illian, malnly llving in urban or suburban areas, there are more than 5500 general practitioners.

Generally, the Importent position of famlly medicine in health care dellivery is not well reflected by medical curricula. This is all the more surprising conslidering that there are substantlal differences between famlly mediclne and hospltal-based mediclne, which are of great significance to the medical student.

Among the arguments advanced by TIddens (1977), the founding dean, there were two which greatly favoured development of a famlly mediclne attachment:

1. Ceneral practice offers the student a range of problems deviating from those in hospltals: the varlation of complaints is virtually 
unl Imited; while the majorlty relate to ininor probllems of heal th, serlous cases can and do occur in suffllclent number; there are distinct connectlons between the somatlc, mental and socllal factors in the complaints presented;

2. General practice is run by a speclitic mode of procedure and specliic problems occur, with which the student should become conversant. Prominent here is the necessity that he should learn to work with tentative concluslons inferred from Ilmited amount of data and to subsequently check new information against the working hypotheslls formed or lginally.

For a new medical faculty aiming at the strengthenling of primary care It was quite natural to Incorporate a three-month attechment in generall practice as an Important element of its six-year curriculum. Major objectlves of the attachment are:

1. Obtalning insight into the backgrounds of the complaints, problems and questlons regularly submitted to the fanlly doctor, as well as coming to know and understand the way in whlch the problems are presented;

2. Acquiring skill in the practice-attuned, methodical approach of such complaints, problems and questions.

3. Gaining proficlency in the preparation of medicel records;

4. Acquirling the knowledge and Insight necessary for adequate care del I very.

The programe was established for the flrst time in the fall of 1978 after one and a half years of preparation by a multidisciplinary teaching team.

Training model features*:

- the attachment to the general practlce covers thirteen weoks; about half the number of students $(24=$ group 1) completed this trainling prlor to a six-month general clinical clerkshlp in a hospltal, the other half $(21=$ group 11$)$ immedlately after this clinical perlod"

- durling the attachment every flfth-year student is assigned to a slingle GP teacher (GPT), who is responslble for the teaching in hls practice;

* More extensive information can be found In:

A.H.M. Mol \& P.A.J. Bouhuljs (Eds), Attachments in General Practlces, Onderwljsreeks RIjksuniversitelt Limburg, Maastrlicht, 1981. 
- the student works in the practloe for about twenty hours week;

- for quisillom of case hilstorles, the student intervlews and, If necessary, exam Ines about fifteen patlents per week; thils activity is not attend by the GT;

- the student prepares a record of hls independent contacts with patlents;

- the GPT concludes the consultatlons with the patlents that have been exam Ined by the student;

- the GPT has, in princlple, a dilly follow-up discussion with the student on the basis of the patient record;

- the student may in addition attend the consulting hour af the general practitloner, be present at team discusslons, malntain contacts with other primary care workers, wislt patients suffering from chronlcal diseases, accompany patients on their way to the hospital, partliclpate in week-end duty, etc.;

- each week the student attends two study group sessions at the faculty:

- the study group conslsts of elght to ten students and is given guldance by a general practitloner-tutor (the GP tutor, 1.e. a staft member of the department of fam 1 ly med lcine);

- group meetings are devoted to consideration of certaln complaints and patient problems and to toplics related to prilmary care in general; the rest of the student's time is spent on Independent study.

Out of a total of about $350 \mathrm{CP}$ 's in the recrultment area of the faculty (within a radius of about $100 \mathrm{~km}$ ) 40 partlclpated in the programe in 1978/79. Certein minimum or Iterla are used to select general practitloners for this Job, such as a well-kept record system and avallabllity of sultable work space. All of them have to attend a two days' workshop to introduce thenselves to thelr teaching role.

Chapter 3 has duel purpose, vlz descrlption of the procedures included In the attachment design for assessment of a student's progress and out I ining the methods employed in the research to collect information about the course of the attachments. The elucliation of the above procedures is considered In conjunction with the assessment pollcy agreed upon by the faculty in 1978.

From 1977 the medlcal faculty has measured learnling results with the ald of so-called progress tests. These tests are structured to estabIllsh on ragular basis how far students have proceeded on thell way 
to the final goal of reaching the baslc-pluyslician level. The test is taken four times a year by all students of the faculty and conslists of yes/no questions about toplcs and disclplines regarded as relevant for a baslc physiclan. The consequence of choosing a programme-Independent test model was that all other forms of testing (such as attachnent assessments) assumed a non-credit character, and served for feedback only. The attachment offers a great many opportunltles for feedback. The dally follow-up discussion with the GPT on the basis of patlent records can be seen as a very important feedback sesslon. The attachment design al so provides for several occaslons on which the student can be briefed in falr detall about the quallty of his functioning. Two testconsisting of 115 true/false items were administered. Also a multiple-cholce test from the medlcal faculty at Rotterdam was used. on all tests, results of a group of graduate baslc physlclans are ayallable. At the end of the attachment the student has a complete consultation with a simulated patient la healthy person instructed to simulate a patlent having speciflic compllalnts). The course of the consultation is recorded on tape and judged by the GP tutor - with the ald of a questlonnalre - whereupon he dlscusses the outcome with the student concermed.

Two types of information are important to programme evaluation: the learning results (product evaluation) and the achleved level of programe implementation (process evalluatlon).

The following sources have been used:

1. A questionnalire about a varlety of attachment aspects to be 11.1 led out by all students at the end of the training. It is made up of 85 questions answered on a 5-point scale and of 2 open questions.

2. A skill check-list completed by the students at the beginning, halfway and at the end of the attachment. This instrument is used to obtain an ldee of the acqulred sklll levels and to check whlch skllis have been put to practlce. Chapter 5 deals with thls IIst In more detiall.

3. The patient records submitted by the student, whlch are discussed in the chapters 4 and 7 .

4. A speclfic worked-time record of the hours number of students have spent on the varlous subjects, see chapter 4.

5. The Maastricht GP Attitude Scale. Thls is flll led out at the beginning and at the end of the attachment perlod and is deslgned to provlde an insight into a student's attltude towards aspects playIng a part in the doctor-patlent relatlonshlp. Chapter 6 enters into the research design and the results. 
6. Study progress assessments; chapters 5 and 8.

7. Progress fest outcomes; chapter 8.

3. A questionnalre bout sever el lements of the atfachment, fll llod out by all oT's after 4 weeks and at the end of the training. It consists of 14 questlons answered on a polnt scale and of 2 open questions. Furthermore, at the end of the attachment, an additional 12-1tem questionnalre was submitted to the GPT's.

9. Minutes of plannling group meetings.

10. Reports by GP tutors on the course of affallrs in their attachment group.

11. Peports on the meetlings with GPT's durling attachments.

12. Information obtained by the researcher in talks with students, teachers, futors, and members of the planning group.

Chapter 4 reports on the 1978-1979 famlly medicl ne attachments. Key elemient of the tralning are interviewing and examining of patlents. Analysls of students' racords of their contacts with patients glves a sultable surwey of the activities involved. Totall flgures for submittad records show that the anticlpated number of flifteen per week has not been reached. Moreover, the rather large diversification of the complaints reported reveals that there are great individuall differences among students. Classifying the record into groups of complaints, It appears that students are chlefly dealing wilth patients suffering from disorders of the locomotor system, problems concerned with the resplratory system, skin dlseases, headache, piain in the chest, eplgastric complaints, and complaints of nervousness. The research has revealed that the supply of complaints is adequately varled. Allso from Information supplled by both students and GPT's appears that, in general, patlents have no objection whatever agoinst beling examined by the students, a matter about which some of the GPT's had had definlte prlor doubts. It is evldent from the results that the GPT's do not thlink that students' activities cause any annoyance to the patlents. on the contrary, several report that patlents appreclibe these contacts because they feel that adequate time is now taken to IIsten to the Ir complaints. Patlent records play an important role in follow-up discusslons with the GPT. Colng by the results, one milght infer that the judgment about the records and their significance in the follow-up disciusion is positive in the majorlty of cases. However, problems dild present themselves. Provlously, the students had acquired insufficlent proflelency in mak Ing records. The oblectlves of the record were not Invarlably adhared to: students ald not always flll out the relevant 
forms prlor to having been informed of the general practltioner"s findings regarding the patlent concerned. The record does not represent the student's activitles and flindings in this case, but a jalnt conclusion. Such devlations from the proposed programme were occaslonally enhanced in Instances where the GPT did not concentrate the follow-up discussllons raund a flixed polnt of time.

Also in other ways students have been involved in the general practice work by thelr teachers: examination of patlents with an "Interesting! pathological history, foddlars' clinics, tean discusslons with other health care workers, week-end duty, first ald, etc.. Activitles of this nature were very much appreclated.

The overall net study tilme of the first attachment group fairly matches the 40-hour schedulle of the programme. The second group spent less time on programed activities. In either case students' work in the practice they had been assigned to took about 20 hours a week, whlch corresponds with the expectations of the pllanning graup. Time expended on matters external to the practlices conformed to expectations as far as the first group was concerned, whereas that of the second group fell short thereof: the latter group devoted less time to sel i-study, whlle also the hours glven to other activitles - partlcularly the study group meetings - were less in number.

After half the attachment perlod had passed, worked hours were on the decline in both groups. If time occupation is regarded as an indlcatlion of the challenging aspect of the attachment, it follows that students" stimulation seems to decrease.

Cooperation by the general practlltioners in the reallzation of the attachment programe has been pald great attention by the faculty from the very outset. The Illnited number of GP's active within the reglon covered by the medlcal faculty makes an attachment of this kind rather vulinerable. Therefore, for successful implementation it is important that the majorlty of the GPT's speak with approvel of their cooperatIon with the students and their presence in the practlice. Also, the answers given by the students about their relationshlps with the GPT's Justlfy the conclusion that they, too, appreclated the guldance recel wed.

Chapter 5 discusses some of the aspects related to the vast area of medical skills and competence. An Inventory of the skllls a student emplloys in the general practlice has been made. This information is a 
cruclal factor in judging whether one of the essentlals of the attachment - namely the active participation of the student - is given its due. The conclusion may be drawn that the famliy medicine attachnent offers students the opportunity to apply a large number of skills in practice. The chapter further establishes the quallity of student performance in terms of medical skllls and compentence with in the framework of the troining. Fram self-Judgments appears that on the average sklll levels increase. On completion of the attachment, judgments about the general sklll level prove predominantly positive. it is true, though, that students who at the outset of the attachment already have completed a slx-month clinical clerkshlp apply more sk\|l| and on the whole recel we more positilwe judgments at the end of the attachment. The initlal level of the students entering their attachment perlod at the beginning of the flith academlc year does not satisty the expectatlons of the planning group. Nevertheless, It may be Inferred from the overall results that active participation in the general practice is feaslble for these students as well.

Chapter 6 explores the influence of the ettachment on a situdent's attitude towards the doctor-patlent rellatlonship, especlaliy in primary heal th care.

Two Instruments were employed:

1. Self-judgments of students and teachers ith respect to relevant aspects of the doctor-patient relationshlp measured with the aid of the 3-factor Maastrlcht GP Attltude Scalle. This questionnalre was submitted to the two groups at the beginning and at the end of the attachment period. Moreover, also the GPT's fllled out both verslions of the attitude questlonnalires.

2. Teacher assessments of their students' performance with regard to patient contacts. For this purpose use was made of the programeeval uatlon questlonnalre.

Factor 1 - preparadness to supply information to patients - Indicated a distinct drop in attitude scores, which could not be related tot GPT oplolons. The results indlcate that on the whole no change accurs in the positive attitude as far as factor 2 - attention pald to psychosoclal problens - Is concerned. This does not Imply however that there should be no change of attltude in individual students, but the net result for the group as a whole is $n$ lll. Whenever changes were encountered, faint connection was found with the viewpolnts prevalling among GPT's :

For factor 3 - avallabillty for the patlent - the scores were subject 
to a slight decrease in the direction of measured GPT attitudes. As In the case of factor 2, no direct connection could be establlshed between the attitudes of students and those of their teachers. The observed changes in attitude are certainly not of a nature which suggests Increased cynleism or Indifference toward pertinent aspects of the doctor-patlent relationship. On the other hand, the outcome underscores the importance of educational activities during the attachment not directly linked up with patient contacts.

Several of the questions contained in the programe evaluatlion questIonnalre concern a student's functioning in relation to patients. The answers given may be regarded as an Indlcation for a professional att t tude. The teachers' opinlions bout this element of student conduct were defInitely positlive. Differences in Judgment between InItial and end phases of the attachment and between the two groups proved not to be signiflcant in any of the cases.

\section{Chapter 7 explores the quallity of student's records*}

In order to check on the quality of reporting and to establish what Improvement, If any, had taken place in the course of the attachiment, - random number of the records collected (complaints of the back and abdominal problems) were oval uated. The results show that the training has not brought about any improvement. Differences in the case of abdom Inal complalnts even warrant the conclusion that a signiflcant deterloration of quallty has accurred. Plotted on a 10-point scale, the general score of the exined records lles between 6 and 7 , but the spreading around the average impl les that this level is not attalned by all students. Most Ilkely, the modest results here found are closely connected $w$ th a lack of experlence on the part of students, teachers and futors regarding the potentlals inherent in sound reportIng. The fact that the reporting quallty decresses rather than Increases suggests that one should not expect the mere practising of this siklll to yleld substentlal improvement. Expllelt prlor exerclse and more attention for reporting methods during the attachment may amend the sittuation.

Chapter 8 concerns the results achleved by students in formatlive knowledge-tests. Averages show that the three tests produce comparable results. The score of the second attachment group is higher on all tests than that of the first. It is al so obvlous that there is a great heterogenelty in knowledge level within the groups. In the thiree tests the second group reached a score whlch was well comparable to that of 
graduate baslc physiclans, whereas the first did not. When GPT"s ware asked whether stiudents' knowledge levels were sufflclent for successful completion of the training, their answers were positive on the average. However, the devlations in the results Justify the inference that number of students (partlcularlly in the flest group) did not have the prlor knowledge necessary to attend a programe of this kind. It may be concluded here that scheduling of the attachment at the beglining of the flfth academlc year is not without risks. Better preparation (or a more strlct selection) in the prevlous currlicular year may reduce these risks. Efforts to relate the influence of the attachment to progress test results were unsuccessful.

Chapter 9 enlarges on the developments in the design of the attachment since 1978/1979. These are descrlbed on the basis of several sallent polints considered essentlall in this respect.

The 12-week famlly medlcine attachment of 5th-year students to a general practlce has gained a permanent place. This form of education has appeared quite satisfactory to both students and staff. Its design has proved a good starting polnt and has shown its feasibillity in practlce, even if it has become clear that not all objectives can be equally realized in all practlces, by all students and all GPT's. Hence, the adjustments and changes incorporated so far can be seen as efforts by whlch to avoid that glven attachment should proceed less satisfactorlly. It has been trled to reallze thls, partly by better preparation of the students and thelr teachers and partly by giving more explicit guidance in the course of the training.

This educational model calls on the part of the faculty for continuous attention for, and immedlate avallabllity to the practice in question. The GP teacher's share in the trainling is substantlal, in both a quantltative and qualltative aspect. He not only grants access to his practioe and patlents, but actually fullflls the role of teacher. He observes, stimulates, advisens and, partlcularly, activelly joins the student in reflecting on the llatter's ect|vitles.

Insufficlent attention for the teaching role of the GPT by the faculty might cause the selected attachment madel to deterlorate Into a model merely calling for routine procedures, or into a much less demanding one, with the student dogging hls teacher and the follow-up discusslon rather assuming the character of an exchange of Information.

In vlew of growing student numbers regular suppletion of the ranks of the trainers should be seen to. In addition to this requlrement, there is another important polnt of concern. At the time the attachment was 
designed, ample partlcipation by cliniclans as resource persons could be counted upon. In the present situation however - malnly as a result of students' own doing - "clinicall contrlbutlions largely concentrate on the border area of primery and secondary health care.

This underlines the fact that the famlly medicine attachment takes a rather isolated position amongst allnical attachments and clerkships, and this in splite of the existing preference for extensive integration of them.

The gavernmental health care pollcy in the Netherlands is almed at curbing hospital care by restrletive control. Should this development persist, primary care tasks wlll increase, which should be anticlpated in medical education. A shift in emphasis in practical medical training towards the patient setting, here primary care, would be a logical move. However, sound preparation for the future task of a physiclan in Dutch healt th care can be achieved only if, by the side of famlly mediclne, also other disclplines within the faculty attune their educatlonal efforts to the above development. Owing to lts experlence with Practical Medical Education in the Ceneral Practice as well as with the appllcation of Interdlsciplinary working methods, the medical faculty of the University of Limburg has created an excellent starting position for successful adaptation of the curricular programme to the changing conditions in the health care domaln.

Further development of Practlcal Medical Education in the General Practice also warrants continuation of educational research. Thls should be focused in particular on the importance of patient consultations and examinations in the acquisition of knowledge and skills and In the development of the future physiclan"s attitude. 


$$
\text { - } 163-
$$

\section{Bijlagen}




\section{PROGRAMAA-EWALUATIE SIUDEVITS P.M.O.-H}

lantwoorden op een 5-puntsschaal: $1=$ volledio ens, $5=$ volledig oneens

1. Ik wond het moilijk on wit de veelheid van ervaringen onderwerpen te kiezen, die ik kon bestuderen

2. Ik had voldoende tijd voor zelfstudie

3. Een stage vam 3 maanden in de huisartserpraktijk vind ik te lang

4. De stage was te zwaar

5. Ik vind dat ik de afgelopen stageperiode veel geleend heb

6. Ik beschikte over onvoldoende kernis en vaardigheden an optimaal te kunner functioneren in de p.m.o.-H stage

7. De organisatle rond de P.m.o.-H stage was goed

8. Ik heb gedurende de p.m.O.-H stage regelmatig gebruik gemaakt van het studielandschap en/of de bibliotheek.

9. Ik heb gedurende de p.m.0.-Fi stage regelmatig gebruit germakt van het skilislab

10. De stageplaats was geschikt on alle activiteiten, zoals die in het blokboek P.m.0.-H amschreven zijn te ondernemen

11. De literatuursuggesties in het blokboek waren waardenol.

12. Ik had liever in een andere praktijk de p.m.o.-H stage grellopen

13. De samenwerking net mijn huisartsopletder was goed

14. Mijn hulsartsopleider stelde mij in stat zelfstandlg te werken

15. Min huisartsopleider had een goed inaicht in de witgangspunten van de stage

16. De nabesprekingen met de h.a.o. waren leerzaam

17. De nabesprekingen met de h.a.o. werden gevoerd aan de hand van mijn joumaals $m: 2.38$

$s=1.06$

$m=2.54$

$s_{1}=1.14$

$\mathrm{m}=4.17$

$s=1.13$

$m=4.04$

$s=0.55$

$m=1.54$

$s=0.51$

$m=2.92$

$s=1.14$

$m=1.50$

$s=0.66$

$\mathrm{m}=3.22$

$s=1.38$

$m=3.77$

$s=1.11$

$m=2.38$

$s=0.88$

$\mathrm{m}=2.75$

$s=0.79$

man $=4.65$

$s=0.78$

$m=1.46$

$g=0.72$

$\mathrm{m}=1.33$

$s=0.56$

$m=2.08$

$s=1.18$

$\mathrm{m}=1.83$

$s=1.05$

$m=1.83$

$s=1.20$ $\mathrm{m}=3.29$

$s=1.06$

$\mathrm{m}=2.38$

$s=1.02$

$m=3.48$

$s=1.33$

$\mathrm{m}=4.79$

$s=0.68$

$m=2.43$

$s=0.93$

$m=3.93$

$s=1.02$

$\mathrm{mi}=1.57$

$s=0.81$

$\mathrm{m}=3.57$

$s=1.08$

$m=4.71$

$\mathbf{s}=0.56$

$m=2.62$

$s=1.07$

$\mathrm{m}=3.05$

$s=0.76$

$\mathrm{mi}=3.81$

$\mathrm{s}=1.36$

$m=1.48$

$\Delta=0.68$

$m=1.71$

$=1.10$

$m=2.19$

$\mathrm{g}=1.08$

$\mathrm{m}=2.24$

$s=1.41$

$m=2.19$

$s=1.40$ 
16. Waat de joumailpat itruter werd ik door de h. a. o. regelmatig bif het onderzoek en behandeling vari andere.

$m=1.42$

$s=0.78$

patienten betrokken

19. ML jn ha.o. gaf aan wat ik moest bestuderen

20. De h.a. o. werkte op mil welnig stinulerend

21. Ik kreeg teveel journaalpatienten toebedeeld

22. De opvatingen van mijn h.a.o. over het huisarts-zijn slulten goed aan bij mijn elgen opvattingen hierover

23. Ik kreeg mijn foumaalpatienten veelall nadat de h.a.o. reeds een consult met hen had afgesloten

24. Mijn joumals waren nuttig in de nabespreking met de h. a.. O.

25. Miln joumaals waren muttig in de nabespreking met de h.a.b.

26. Mijn journaals waren nuttig voor een bespreking in de onderwi.jsgroep

27. Mjin joumaals waren nuttig voor mijn indivicuele studie-activiteiten

28. Ik vind dat het invullen van joumaals weinig zin had

29. In vulde mi.jn journaals veelal pas in het 'net' in nadat $i k$ met mijn h.a.o. gesproken had

30. De patientgerichte onderwijsgroepsbijeenkansten vond Ik zinvol

31. De themagerichte anderwijsgroepsbijeenkansten vond ik invol

32. De samenwerking in de onderwijsgroep was goed

33. De groepsbijeenkansten vormden voor mij een essentivele bijarage aan de p.m.o.-H stage

34. De h.a.b. stimuleexde de groep door het stellen van vragen en het geven van samenvattingen

35. De h.a.b. bracht regelmatig zijn elgen kennis en opvattingen in de groep naar voren

36. De h.a.b. besteedde voldoende aandacht aan het: functioneren van de groep

\begin{tabular}{|c|c|}
\hline $\begin{array}{l}m=3.63 \\
s=0.97\end{array}$ & $\begin{array}{l}\mathrm{m}=4.05 \\
\mathrm{~s}=1.32\end{array}$ \\
\hline$m=3.87$ & $\mathrm{~m}=3.6 \mathrm{2}$ \\
\hline$s=1.25$ & $s=1.24$ \\
\hline$m=4.58$ & $\mathrm{~m}=4.19$ \\
\hline$s=0.65$ & $s=0.68$ \\
\hline $\mathrm{m}=2.21$ & $\mathrm{~m}=2.81$ \\
\hline$s=1.14$ & $s=1.40$ \\
\hline$m=3.92$ & $m=4.24$ \\
\hline$s=1.74$ & $s=1.22$ \\
\hline $\mathrm{m}=1.75$ & $m=2.38$ \\
\hline$s=1.11$ & $s=1.16$ \\
\hline$m=2.27$ & $\mathrm{~m}=2.65$ \\
\hline$s=1.32$ & $s=1.31$ \\
\hline$m=2.50$ & $m=2.811$ \\
\hline$s=1.29$ & $s=0.93$ \\
\hline$m=2.46$ & $m=3.10$ \\
\hline$s=1.14$ & $s=1.22$ \\
\hline$m=4.25$ & $\mathrm{~m}=3.86$ \\
\hline$s=0.99$ & $s=1.01$ \\
\hline $\mathrm{m}=4.29$ & $\mathrm{~m}=4.90$ \\
\hline$s=1.00$ & $s=0.44$ \\
\hline $\mathrm{m}=1.96$ & $m=2.43$ \\
\hline$s=1.16$ & $s=1.03$ \\
\hline$m=2.75$ & $m=2.43$ \\
\hline$s=1.42$ & $s=1.33$ \\
\hline$m=2.38$ & $\mathrm{~m}=3.14$ \\
\hline$s=1.10$ & $s=1.06$ \\
\hline$m=2.38$ & $\mathrm{~m}=3.05$ \\
\hline$s=1.17$ & $s=1.50$ \\
\hline$m=2.21$ & $m=2.48$ \\
\hline$s=0.93$ & $s=1.12$ \\
\hline $\mathrm{m}=1.71$ & $\mathrm{~m}=1.67$ \\
\hline$s=0.81$ & $s=0.66$ \\
\hline$=2.50$ & $\mathrm{~m}=3.00$ \\
\hline$=0.98$ & $\mathbf{s}=1.00$ \\
\hline
\end{tabular}

$\mathrm{n}=1.90$

$s=1.4$

$\mathrm{m}=4.05$ 2 
37. De groep zou zoncer de h.a.b. net zo goed hebben gefunctioneerd

38. De individuele besprekingen met mijn $h_{w} a . b$. waren leerzaam

39. De h.a.b. werkte op mij weinig stimulerend

40. Mijn h.a.b. gaf aan wat ik moest bestuderen

41. Ik had liever en andere h.a.b. gehad

42. We hadden meer inhoudisdeskundigen moeten uitnodigen

43. De inbreng van de inhoudsdeskundigen was in het algemeen weinig verhelderend

44. Het blokboek p.m.o. - H bevatte een aanbeveling om in de stage vooral aandacht te besteden aan 23 klachtengroepen.

In hoeverre heb jij je in je stage-activiteiten (onderzoek patiënten, gesprekken met h.a.o. en h.a.b.,

literaturur, onderwijsgroep etc.) laten leiden door die aanbeveling

45. Het blokboek p.m. O.-H bevatte een aanbeveling an in de stage aandacht te besteden aan 16 thema's

In hoeverre heb $j i j$ je in je stage-activiteiten laten

leiden door die aanbeveling

46. De patient met hoofdpijn

47. De patient die hoest

48. De patient die het benauwd heeft

49. De patient die bloed opgeeft

50. De patiënt met pijn op de borst

51. De patiênt met pijn in schouder, amri en hand

52. De patient met rug- of lendeklachten

53. De patiënt met heup-, been- en voetklachten

$$
\begin{array}{ll}
m=3.83 & m=3.62 \\
s=0.92 & s=1.07 \\
m=2.48 & m=2.45 \\
s=1.20 & s=1.28 \\
m=3.58 & m=3.76 \\
s=1.10 & s=1.09 \\
m=4.29 & m=4.05 \\
s=0.95 & s=0.86 \\
m=4.38 & m=3.86 \\
s=0.82 & s=1.15 \\
m=2.78 & m=2.81 \\
s=1.20 & s=1.36 \\
m=4.08 & m=4.00 \\
s=0.93 & s=0.77
\end{array}
$$

$m=3.33$

$\mathbf{s}=1.20$

$$
m=4.33
$$$$
s=0.97
$$

$\mathrm{m}=3.29$

$s=1.08$

$\mathrm{m}=4.10$

$s=0.77$

$\mathrm{m}=1.88$

$\mathrm{mi}=2.10$

$s=0.54$

$s=0.83$

$\mathrm{m}=1.46$

$m=1.52$

$s=0.51$

$s=0.51$

$\mathrm{m}=2.00$

$\mathrm{m}=2.29$

$s=0.72$

$s=0.64$

$m=3.71$

$\mathrm{m}=3.81$

$\mathrm{s}=1.23$

$s=1.03$

$m=2.00$

$m=1.90$

$s=0.51$

g -0.77

$\mathrm{m}=1.71$

$m=1.81$

$\mathrm{s}=0.62$

$s=0.93$

$m=1.58$

$m=1.76$

$s=0.58$

$\mathrm{s}=0.62$

$\mathrm{m}=1.88$

$m=2.05$

$s=0.68$ 
54. Het kind met wlekjes

55. Levensbedreigande acute toestanden

56. De patiënt die overspannen is

57. De patibnt die duizelig is

58. De patient met abnomale hoge bloeddruk

59. De patient met acute hoge koorts

60. De patiént met magklachten

61. Het kind met hoge koorts

62. De patient die venmold is

63. De patiënt met dorst

64. De patiënt met onderbulkklachten

65. De patient met obstipatie

66. De patiënt met sexuele problemen

67. De patiënt met oedemen

68. Het kind met buikpi.jn

69. Bas.jsgegevens van de praktijk

70. Samenwerkingswonment

71. Het verwijizen

72. voorschrijft en opvolggedrag $m=2.88$

$s=1.12$

$\mathrm{m}=3.78$

$s=1.24$

$m=2.75$

$s=1.22$

$\mathrm{m}=2.25$

$s=0.79$

$m=2.00$

$s=0.88$

$\mathrm{m}=3.33$

$s=1.05$

$\mathrm{m}=2.00$

$s:=0.78$

$\mathrm{m}=3.08$

$s=1.10$

$\mathrm{m}=2.29$

$\mathrm{s}=0.95$

$\mathrm{m}=3.75$

s. $=0.90$

$\mathrm{m}=2.38$

$s=0.97$

$\mathrm{m}=2.71$

$s=0.91$

$\mathrm{m}=3.42$

$s=1.14$

$\mathrm{m}=3.21$

$\mathrm{s}=1.06$

$\mathrm{m}=2.63$

$\mathrm{s}=0.88$

$\mathrm{m}=3.00$

$\mathbf{s}=1.32$

$\mathrm{m}=3.00$

$\mathrm{s}=1.29$

$\mathrm{m}=2.58$

$s=0.93$

$\mathrm{m}=3.13$

$s=1.08$ $m=2.24$

$s=0.89$

$\mathrm{m}=3.48$

$s=1.03$

$m=2.86$

$s=1.39$

$\mathrm{m}=2.19$

$s=0.81$

$m=2.24$

$s=1.00$

$\mathrm{min}=3.67$

$\mathrm{s}=0.80$

$m=2.62$

$s=0.97$

$\mathrm{m}=2.67$

$s=1.02$

$\mathrm{m}=2.62$

$s=0.86$

$\mathrm{m}=4.29$

$s=0.96$

$\mathrm{m}=2.62$

$s=0.97$

$m=2.95$

$s=1.20$

$\mathrm{m}=3.57$

$s=1.33$

$\mathrm{m}=3.24$

$s=0.94$

$m=2.57$

$s=0.98$

$m=3.48$

$s=0.93$

$m=3.57$

$s=1.25$

$\mathrm{m}=3.33$

$s=1.15$

$\mathrm{m}=3.71$

$s=1.27$ 
73. Crisisinterventie

74. De patiënt ais gezinslid

75. Het arts-patient-contact, gezien vamuit het standpumt van patlëntenrecht.

76. De chemuische diagnostiek van de huisarts

77. Rísicogroepen

78. Evaluatie van gegeven zorg

79. De begeleiding van stervenden en het nouwproces

80. De begeleiding van de chronische patïënt

81. Je eigen persoon als hulpverlener

82. De arts-patient-relatie als functionele samenwerkingsrelatie

83. Arbeldsproblemen en de huisarts

84. Relatieproblematiek

85. In hoeverre heb je aandacht besteed aan het blokboek

$\begin{array}{ll}\mathrm{m}=2.75 & \mathrm{~m}=3.71 \\ \mathrm{~s}=1.45 & \mathrm{~s}=1.15 \\ \mathrm{~m}=3.29 & \mathrm{~m}=3.57 \\ \mathrm{~s}=1.37 & \mathrm{~s}=1.25 \\ \mathrm{~m}=3.46 & \mathrm{~m}=4.05 \\ \mathrm{~s}=1.28 & \mathrm{~s}=1.02 \\ \mathrm{~m}=3.42 & \mathrm{~m}=3.14 \\ \mathrm{~s}=1.32 & \mathrm{~s}=1.56 \\ \mathrm{~m}=3.00 & \mathrm{~m}=2.62 \\ \mathrm{~s}=1.02 & \mathrm{~s}=0.97 \\ \mathrm{~m}=3.46 & \mathrm{~m}=3.67 \\ \mathrm{~s}=1.14 & \mathrm{~s}=1.02 \\ \mathrm{~m}=3.46 & \mathrm{~m}=3.62 \\ \mathrm{~s}=1.25 & \mathrm{~s}=1.36 \\ \mathrm{~m}=3.08 & \mathrm{~m}=3.62 \\ \mathrm{~s}=1.14 & \mathrm{~s}=1.07 \\ \mathrm{~m}=2.29 & \mathrm{~m}=2.52 \\ \mathrm{~s}=1.12 & \mathrm{~s}=1.08 \\ \mathrm{~m}=3.29 & \mathrm{~m}=2.86 \\ \mathrm{~s}=1.33 & \mathrm{~s}=1.31 \\ \mathrm{~m}=3.00 & \mathrm{~m}=3.48 \\ \mathrm{~s}=1.14 & \mathrm{~s}=1.08 \\ \mathrm{~m}=2.48 & \mathrm{~m}=3.00 \\ \mathrm{~s}=0.99 & \mathrm{~s}=1.18 \\ \mathrm{~m}=3.13 & \mathrm{~m}=3.79 \\ \mathrm{~s}=1.08 & \mathrm{~s}=0.98\end{array}$

$\mathrm{m}=2.75$

$m=3.71$

$\mathrm{m}=3.57$

$\mathrm{m}=3.29$

$=1.25$

$\mathrm{m}=4.05$

$m=3.46$

$s=1.02$

$m=3.42$

$\mathrm{m}=3.14$

$s=1.56$

$\mathrm{m}=3.00$

$\mathrm{m}=22_{n} 62$

$m=3.67$

$s=1.02$

$\mathrm{m}=3.46$

$\mathrm{m}=3.62$

$=1.36$

$\mathrm{m}=3.08$

$\mathrm{m}=3.62$

$\mathrm{s}=1.08$

$s=0.98$

\section{Open vragen:}

86. Wat warcieer je in het PMOH?

87. Wat is je kritiek on het PWOH? 


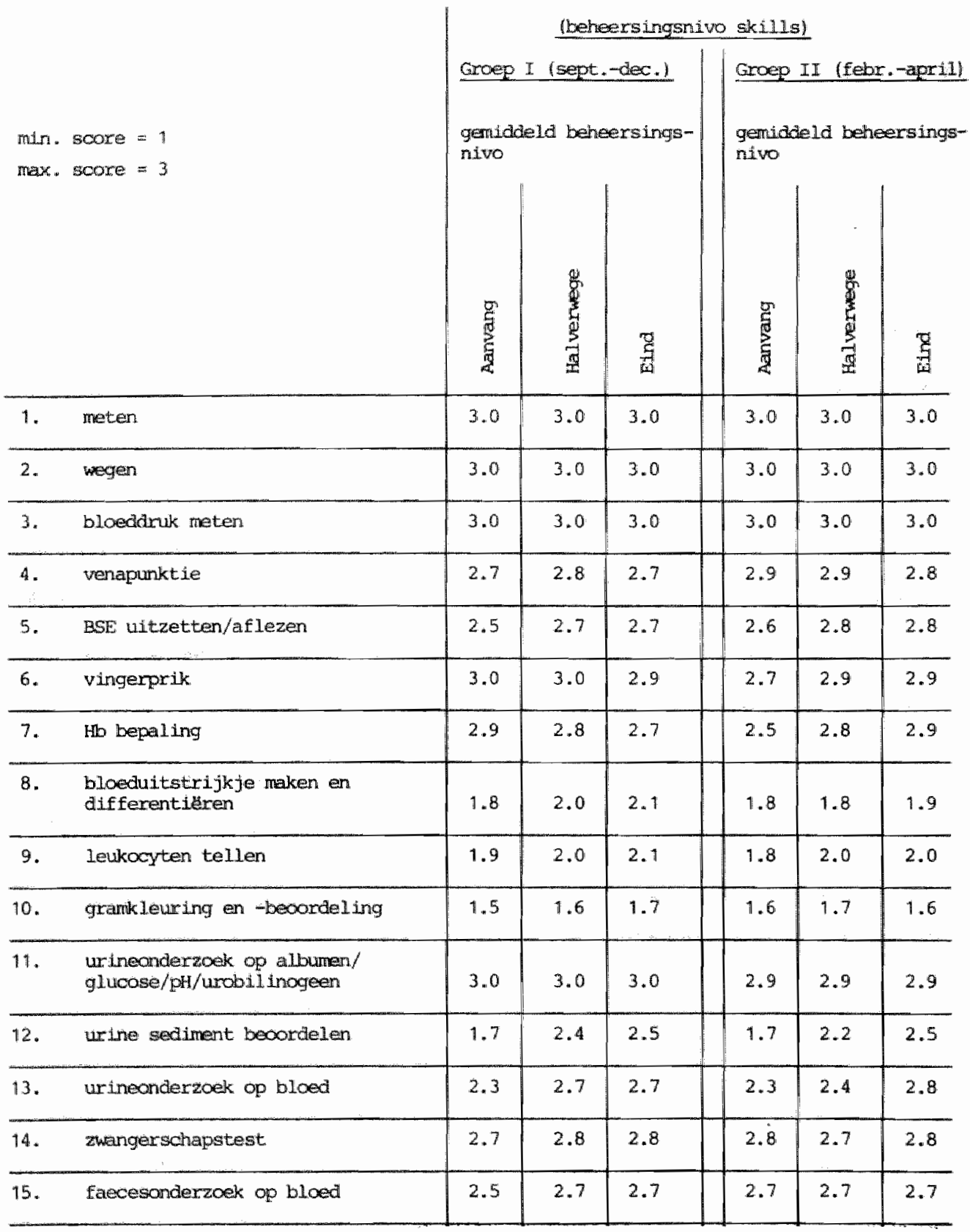




\begin{tabular}{|c|c|c|c|c|c|c|c|}
\hline & & $\begin{array}{l}\text { Groep } \\
\text { genida } \\
\text { niwo }\end{array}$ & $\begin{array}{c}\text { Ibeh } \\
\text { Isept } \\
\text { la ber } \\
\frac{8}{8} \\
\frac{5}{8} \\
\frac{5}{4}\end{array}$ & $\begin{array}{l}\text { arsingsn } \\
\text { aec } 1 \\
\text { rsings- }\end{array}$ & $\begin{array}{l}\text { skill } \\
\text { Groep } \\
\text { gentido } \\
\text { niwo }\end{array}$ & If ifer & 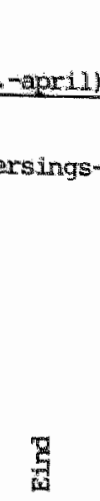 \\
\hline 16. & $\begin{array}{l}\text { fysisch-diagnostisch onderzoek } \\
\text { van het hart }\end{array}$ & 2.2 & 2.5 & 2.7 & 2.8 & 2.9 & 2.9 \\
\hline 17 & $\begin{array}{l}\text { fysisch-diagnostisch onderzoek } \\
\text { van de longen }\end{array}$ & 2.4 & 2.7 & 2.9 & 2.9 & 2.9 & 2.9 \\
\hline 18. & $\begin{array}{l}\text { fysisch-diagnostisch onderzoek } \\
\text { van de buik }\end{array}$ & 2.5 & 2.7 & 3.0 & 2.9 & 3.0 & 2.9 \\
\hline 19. & $\begin{array}{l}\text { Eysisch-diagnostisch onderzoek } \\
\text { van de schouder }\end{array}$ & 2.1 & 2.5 & 2.7 & 2.2 & 2.5 & 2.8 \\
\hline 20. & $\begin{array}{l}\text { fysisch-diagnostisch onderzoek } \\
\text { van de elleboog }\end{array}$ & 2.1 & 2.6 & 2.7 & 2.3 & 2.6 & 2.8 \\
\hline 21. & $\begin{array}{l}\text { fysisch-diagnostisch onderzoek } \\
\text { van de pols en de hand }\end{array}$ & 2.0 & 2.6 & 2.7 & 2.2 & 2.7 & 2.8 \\
\hline 22 & $\begin{array}{l}\text { fysisch-diagnostisch onderzoek } \\
\text { van de rug }\end{array}$ & 2.3 & 2.7 & 2.9 & 2.3 & 3.0 & 2.9 \\
\hline 23. & $\begin{array}{l}\text { Eysisch-diagnostisch onderzoek } \\
\text { van de heup }\end{array}$ & 2.2 & 2.7 & 2.7 & 2.5 & 2.8 & 2.9 \\
\hline 24. & $\begin{array}{l}\text { fysisch-diagnostisch onderzoek } \\
\text { van de knie }\end{array}$ & 2.4 & 2.7 & 2.8 & 2.5 & 2.9 & 2.9 \\
\hline 25. & $\begin{array}{l}\text { fysisch-diagnostisch onderzoek } \\
\text { van enkel en voet }\end{array}$ & 1.9 & 2.5 & 2.6 & 2.2 & 2.5 & 2.6 \\
\hline 26. & onderzoek van de hersenzenuwern & 2.0 & 2.2 & 2.5 & 2.1 & 2.1 & 2.5 \\
\hline 27 & $\begin{array}{l}\text { newrologisch onderzoek var } \\
\text { rorp en extremiteiten }\end{array}$ & 2.2 & 2.6 & 2.7 & 2.2 & 2.3 & 2.5 \\
\hline
\end{tabular}




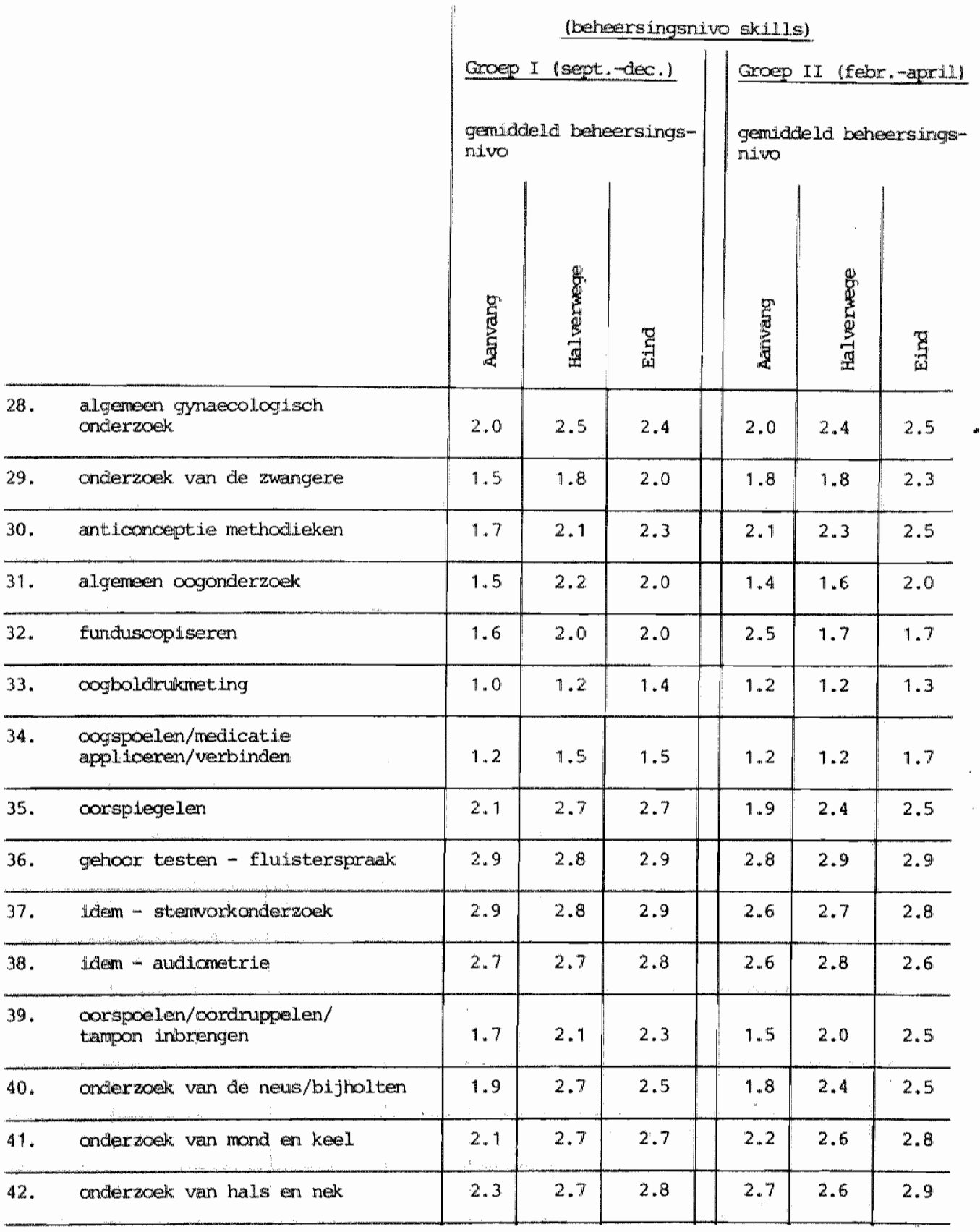




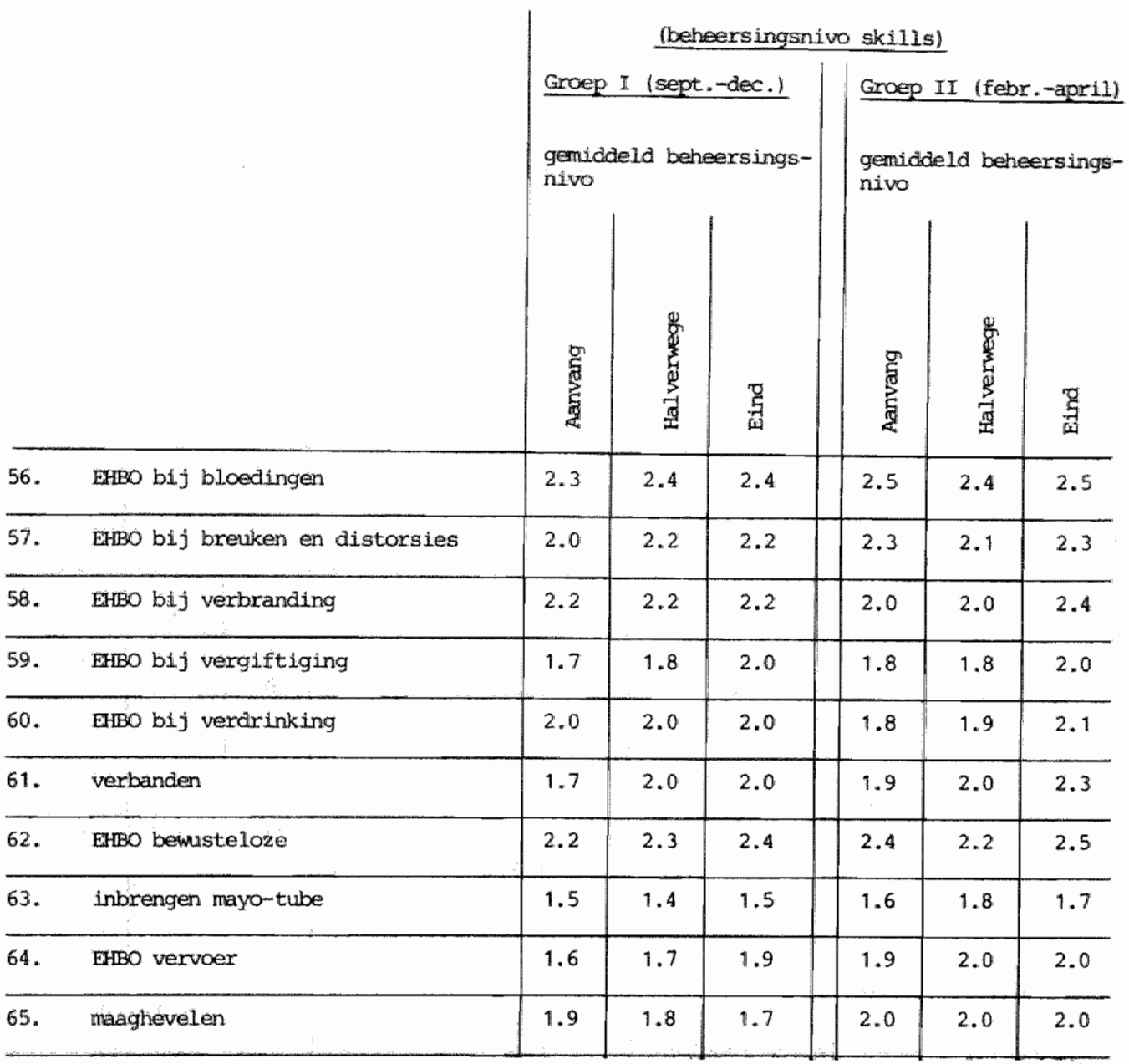


BIJAGE 2

vervolg

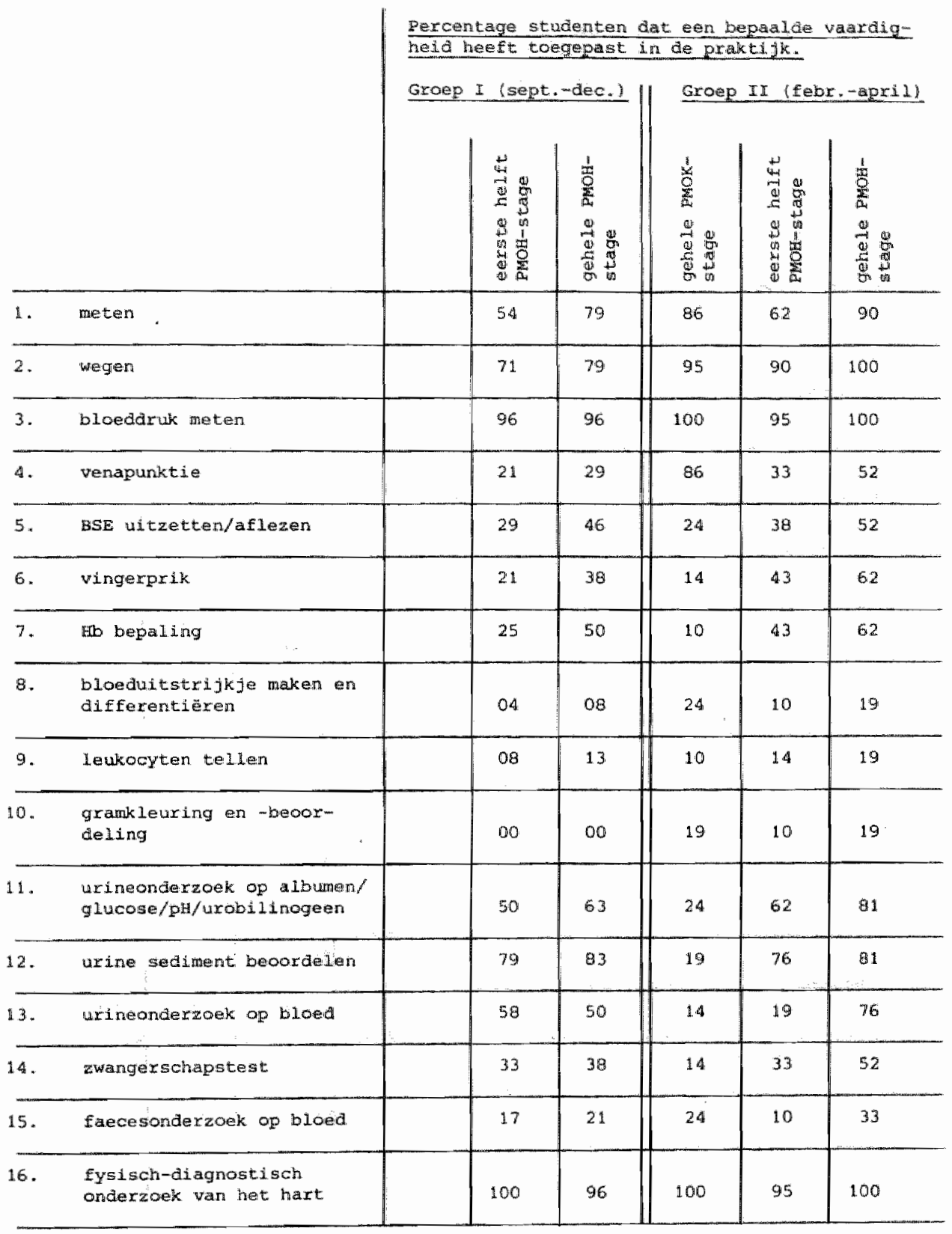




\begin{tabular}{|c|c|c|c|c|c|c|}
\hline & \multicolumn{5}{|c|}{ 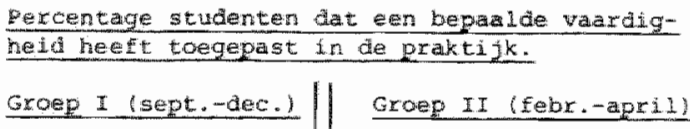 } \\
\hline & & 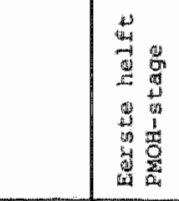 & 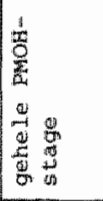 & 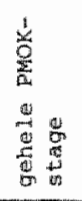 & 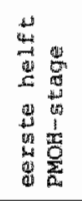 & 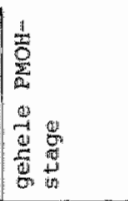 \\
\hline 17. & $\begin{array}{l}\text { Eysilsch-diagnostisch } \\
\text { onderzoek van de longen }\end{array}$ & 100 & $10 G$ & 100 & 100 & 100 \\
\hline & $\begin{array}{l}\text { fystsch-diagnostisch } \\
\text { onderzoek van de bujk }\end{array}$ & 100 & 100 & 100 & 100 & 100 \\
\hline 19. & $\begin{array}{l}\text { fysischmiagnostisch } \\
\text { onderzoek van de } \\
\text { schouder }\end{array}$ & 100 & 100 & 96 & 100 & 95 \\
\hline 20. & $\begin{array}{l}\text { Eysisch-diagnostisch } \\
\text { onderzoek van de elle- } \\
\text { boog }\end{array}$ & 96 & 100 & 90 & 81 & 95 \\
\hline 21. & $\begin{array}{l}\text { Eysisich-diagnostisch } \\
\text { onaerzoek van de pols } \\
\text { en de hand }\end{array}$ & 100 & 100 & Bil & 86 & 95 \\
\hline 22. & $\begin{array}{l}\text { fysisch-diagnostisch } \\
\text { onderzok van de rug }\end{array}$ & 100 & 100 & 90 & 100 & 100 \\
\hline 23. & $\begin{array}{l}\text { EXsisch-diagnostisch } \\
\text { onderzoek van de heup }\end{array}$ & 92 & 100 & $a 1$ & 86 & 90 \\
\hline 24. & $\begin{array}{l}\text { fysisdh-diagnostiach } \\
\text { ondergok van de knie }\end{array}$ & 100 & 96 & 100 & 95 & 100 \\
\hline 25. & 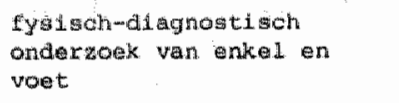 & 100 & 96 & 76 & 86 & 90 \\
\hline 26. & $\begin{array}{l}\text { onderzoek van de hersen- } \\
\text { zemuwen }\end{array}$ & 58 & 79 & 71 & 29 & 67 \\
\hline 27 & $\begin{array}{l}\text { neurologisch ondierzoek van } \\
\text { romp en extremiteiten }\end{array}$ & 79 & 83 & 62 & 43 & 86 \\
\hline
\end{tabular}




\begin{tabular}{|c|c|c|c|c|c|c|}
\hline & \multicolumn{5}{|c|}{$\begin{array}{l}\text { Percentage studenten dat een bepadide wardjg- } \\
\text { ineid heeft toegepast in de praktijk. } \\
\text { Groep I (sept.-dec.) } \| \text { Groep II (febr--aprih) }\end{array}$} \\
\hline & & 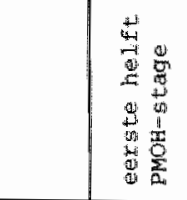 & 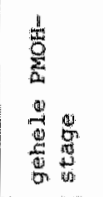 & 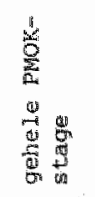 & 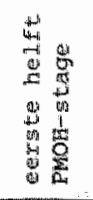 & 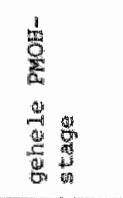 \\
\hline 28. & $\begin{array}{l}\text { aìgemeen gynaecologisch } \\
\text { onderzoek }\end{array}$ & 63 & 63 & 67 & 67 & 71 \\
\hline 29. & onderzoek van de zwangere & 46 & 38 & 48 & 43 & 48 \\
\hline 30 & anticonceptie methodieken & 21 & 38 & 24 & 29 & 52 \\
\hline 31. & Agemeen oogonderzoek & 63 & 63 & 33 & 38 & 71 \\
\hline 32. & Funduscopiseren & 54 & 63 & 57 & 52 & 62 \\
\hline 33. & aagbollärukmeting & 04 & 08 & 19 & 05 & 10 \\
\hline 34 & $\begin{array}{l}\text { oogspoelen/medicatie } \\
\text { appliceren/verbinden }\end{array}$ & 13 & 08 & 10 & 10 & 14 \\
\hline 35. & oorspiegelen & 100 & 100 & 43 & 95 & 95 \\
\hline 36. & $\begin{array}{l}\text { gehoor testen } \\
\text { - fluisterspraak }\end{array}$ & 58 & 83 & 38 & 48 & 81 \\
\hline 37. & i dem - stemvorkonderzoek & 46 & 71 & 24 & 24 & 48 \\
\hline 38. & Sden - audionetrie & 33 & 54 & 10 & 19 & 43 \\
\hline 39. & $\begin{array}{l}\text { oorspo len/oordruppeien/ } \\
\text { tampon intwengen }\end{array}$ & 33 & 46 & 05 & 38 & 62 \\
\hline 40. & $\begin{array}{l}\text { onderzoek van de neus/ } \\
\text { bijholten }\end{array}$ & 83 & 88 & 29 & 71 & 76 \\
\hline $41 *$ & $\begin{array}{l}\text { onderzoek wan mond en } \\
\text { keel. }\end{array}$ & 96 & 100 & 81 & 90 & 100 \\
\hline 42. & onderzoek van hals en nek & 96 & 100 & 90 & 86 & 100 \\
\hline
\end{tabular}




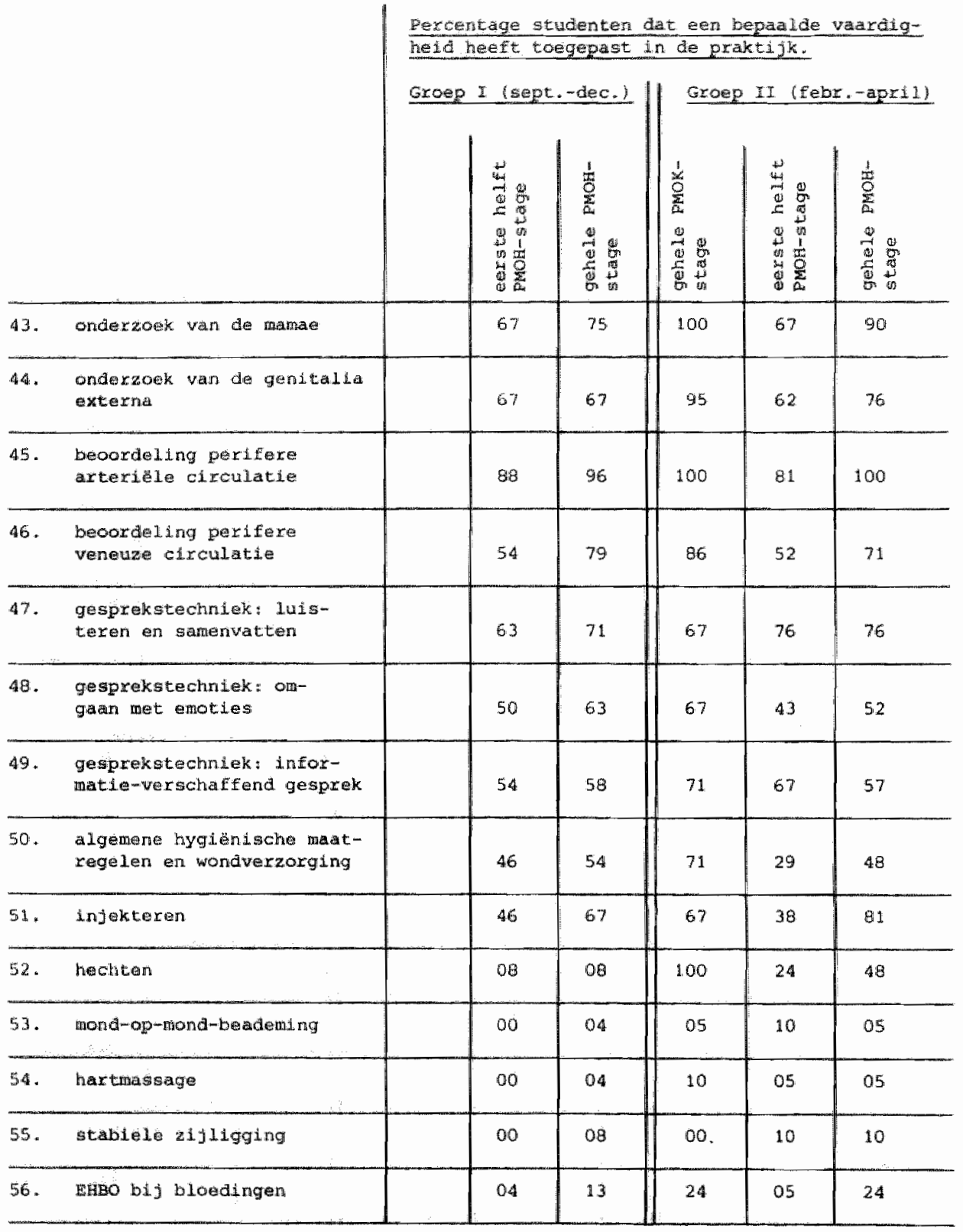




\begin{tabular}{|c|c|c|c|c|c|c|}
\hline & \multicolumn{5}{|c|}{$\begin{array}{l}\text { percertage sturenten dat een bapalde vaardig- } \\
\text { heid heeft toegepast in de praktidk. } \\
\text { Groep I (segt.-dec.) || Groep II (febr.-aprt1) }\end{array}$} \\
\hline & & 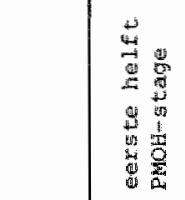 & 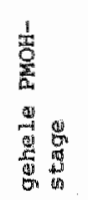 & 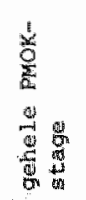 & 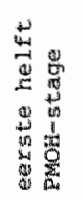 & 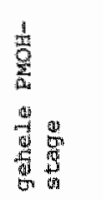 \\
\hline 57. & $\begin{array}{l}\text { EHBO bij breuken en } \\
\text { distorsies }\end{array}$ & 13 & 17 & 29 & 05 & 24 \\
\hline 58 & EKBO bij verbranding & 00 & 08 & 10 & 05 & 24 \\
\hline 59. & EHBO bij vergiftiging & 00 & 00 & 10 & 05 & oo \\
\hline 60. & EHBO bij werarinking & 00 & 00 & 00 & oo & 00 \\
\hline 61. & verbaraden & 21 & 50 & 52 & 19 & 48 \\
\hline 62. & EHBO bewrusteloze & 00 & 13 & 24 & 05 & 14 \\
\hline 63. & inbrengen mayo-tube & $\infty 0$ & 00 & 24 & 00 & 00 \\
\hline 64. & EHBo vervoer & 00 & 00 & 05 & 05 & 05 \\
\hline 65. & maaghevelen & 00 & 00 & 33 & 10 & 0.5 \\
\hline
\end{tabular}




\section{Llteratuur}

Abrahamson, S., Theoretical Basis of Clerkshlp Design: Bethevlorlstic Perspective. Proceedings 21 st Annual Conference on Research in Medical Education. AAMC, Washington, 1982.

Barr, D.M. et al." The Rockford School of Medlelne Undergraduate Quallity Assurance Program. Journal of Madlcal Education, 51, $370-377,1976$.

Bender, W., Krltische momenten in de medische studle, enkele recente onder zoeksgegevens. Med Isch Contact, 13, 402-403, 1979.

Bergsma, J., De hulsarts in de storm; opmerkelllke felten over de hul sartspraktlJk. Internedlalr 17, nr. 20, pag. 1-7, 1981.

Boshulzen, H.P.A. \& Cl aessen, H.F.A., Cognllt leve verwerkling on onthouden van patlëntgegevens; een onderzoek blj studenten in Utrecht en Maastrlcht. In: H.G. Schmldt (red.), Probleengestuurd Onderwlıs. Svo-reeks 57, Flevodruk, Harlingen, 1982.

BouhulJs, P.A.J., Leren probleamoplossen door het observeren van oplossingen. Groep OnderwlJ sresearch rapport nr.21. Technische Hogeschool, Einidhoven, 1976.

BouhuiJs, P.A.J., Groepsonderwlis in het medisch currlculum. Metamed lca, 57, 17-20, 1978.

Bouhuljs, P.A.J., Brouwer W. \& Mol A.H.M., Praktisch medisch onderwijs in de hulsartspraktijk. Hul sarts en Wetenschap, 23, 8-12, 1980 .

Breuker, J.A.P.J., Aval I abll Ity of Knowledge. Dilssertatle UnIversitelt van Amsterdam, 1981 .

Brouwer, W., Prakt Isch Madilsch Onderwljs In Hul sartspraktijken. Interne discusslenota. Fakultelt der Geneeskunde, Rljksunlversitolt Lllmburg, 1977 .

Bruner, J.S., Toward Theory of Instructlon. Harvard UnIversilty Press, Cambridge, 1966.

Bruner, J.S., The Relevance of Education. Allan \& UnwIn, London, 1972. Brunswik, E., Perception and Representative Deslgin of Psychologlcal Experiments. University of Call fornla Press, Berkeley, 1956. 
Buls, P., Het functioneren van terugkoppel Ing In het wetenschappelljk onderwils; twe voorafgaande voorwarden. Proefschrift Unlversitelt van Amsterdam. Swets \& Zeltilinger, Lisse, 1978.

Byrne, N. \& Cohen, R., Dservational study of Cilnical Clerkship Activities. Journal of Medical Education, 48, 919-927, 1973.

Cassee, E., Nar de Dokter. Boom, Meppel, 1973.

Cormissle Voorberelding Medische Facultelt Masstricht, Basisfllosofle Achtste Medische Facultelt. Medisch Contect, 33, 879-884, 1972.

Corte, E. de e.a., Beknopte didaxologle. Gron Ingen, 1976.

COWOG, Checkllst technIsche vardigheden Beroepsoplelding Hullsartsgeneoskunde. Deel I en 11. COWOG, Groningen, 1977.

Crombag, H.F.M., De IJsvrlje havens van Hoorwegen. In: Crombag, H.F.M. en T.M. Chang (red.). Een klelne zoölogle wan het onderwijs. Universitaire Pers, Lellen, 1978.

Crombag, H.F.M., de Wijkersloot, J.L. \& van Tuyll van Serooskerken, E.H., Over het oplossen van casuspositles. TJeenk Wlllink, Gron Ingen, 1972.

Cronbach, L.J. \& Snow, R.E., Aptltudes and Instructlonal Methods: a Handbook for Research on Interactlons. Irvington Publ., New York, 1977.

Dean, T.M., Attltudes of medlcal students toward general practlce. British Journal of Medlical Education, 6, 108-113, 1972.

Dewey, J., Democracy and education. McMill Ian, Now York, 1916.

Dewey, J., Experlence and Educatlon. McMillan, Now York, 1975.

Duursma, S.A., Koperberg. I.Ph.L. \& Zweerts de Jong, W.J. (red.), Kompas voor de hulsarts: een losbladlg compendl um voor de algemene praktiJk. Oosthoek, Utrecht, 1973.

Elsner, E.W., Emerging models for educational evaluation. School Revlew, 573-591, 1972 .

Elrlck, H., The Clinlical Education of the Medicall Student. Journal of Medical Education, 42, 453-459, 1967.

El stelin, A.S., Shulman, L.S. \& Sprafka, S.A., Medical Problam Solving, an Analysis of Clinical Reasoniling. Hervard University Press, Cambrldge, 1978.

Engel, G.L., Care and feeding of the medlcal student. Journal of the Amerlcan Medlcal Assoclation, vol. 215, 7, 1135-1141, 1971.

Eron. L.D., The Effect of Modical Education on Modical Students" Attitudes. Journal of Medlcall Education, 30, 559-566, 1955.

Eron, L.D., The Effect of Madlcal Education on AttItudes: a Follow-up Study. Journal of Medlcal Education, 33, 25-33, 1958. 
Es, A. van, Anatomle van hot gevoell. HarleklJn, Wesbroek, 1979.

EverwIJn, S.E.M. \& Muggen, G., Methoden voor het meten van studletljd. In: van Woerden, W.M. e.a. (red.). Onderwljs lim de maak. Spectr um , Utrecht, 1973.

Flshbein, M. \& Azen, 1., Bellef, Attltude and Behavlour: an Introduction to theory and research. Addison-weslly, Readling, 1975 .

Flexner. A., Madical Education in the United States. Carneglo FoundatIon, New York, 1910.

Frledman, C.P., Baker, R.M. Palge llderton, E., Functions of a Fanlly Medleine Preceptorshlp. Journal of Medlcal Education " $54,567-575,1979$.

Galesloot, J. \& de Graaf, E*, Casulstlek uit de hulsartspraktijk. Bohn, Scheltema \& Holkema, Utrecht, 1981.

Gerr 1tsma, J.G.M. \& Reltsma, F.E., Tussentljds rapport betreffende het project soclale vaardigheden van de arts voor vijfdejaars studenten. Intern rapport afdelling onderwlJ sontwikkelling. RIJksuniversitelt Utrecht, 1973.

Gerr 1tsma, J.G.M. \& Small, J.A., Grensverschuivingen in het medilsch onderwljs. Costhook, Scheltema \& Holkema, 1974.

Gerrltsma, J.G.M. \& Smal, J.A., De werkwljze van hulsarts en internist; en vergelijkend onderzoek met behulp van een interacHeve patlëntens Imulatle. DIssertatie. Wetenschappell Ijke UItgever lJ Bunge, Utrecht, 1982 .

Glaser, R., Components of a Psychology of Instruction: towards a Sclience of Design. Revlew of Educatlonal Research, Vol. 46, $1,1-24,1976$.

Groot, A.D. de, Hoe stelt men elndtermen op? In: CWHWO, Handvatten voor de herprogrammerling. Academl sche Raad, Den Haag, 1974.

GIJ selaers. W., Programma-eval uatlestrateg le voor probleengestuurd onderwijs. Doktoral scriptle, RlJksunlversitelt Llimburg, Maastrleht, 1982 .

Herden, R.M. Gl Geson, F.A., Assessment of clinical competence using an objective structured clinlcal examination (OSCE). Medlcal Education 1979, 13, 41-54.

Hofster, W.K.B., Indlviduel verschillen en averechtse toepassing. Ned. T. Psychol. 24, 482-493, 1969.

Hotstee, W.K.B., Evaluatle: een methodologlsche anallyse. TiJdschrlft voor Onderw ll sresearch, 7, 193-202, 1982 .

Imbos, TJ. \& VerwlJnen, G.M., Evalluette aan de Madlsche Facultelt Maastrlcht, Metamedlica, 57, 21-32, 1978 . 
Imbos, Tj. \& VerwIJnen, G.M., Voortgangstoetsing an de medische foculltelt Maastrlicht. In: H.G. Schmidt (red.). Probleengestuurd Onderwijs. Bijdragen aan de OnderwiJsresearchdagen 1981. svo-reeks nr. 57, Flevodruk, Harllingen, 1982.

Imbos, TJ., wan der Lugt, P. \& VerwiJnen, G.M." The impact of several elements of neurologlcal education on cognilive evaluation in a problem-orlented currlculum. Paper Symposium on NeurollogI cal Education, Kyoto, 1982.

Katz, E., Doctor-patlent exchanges: a dlagnostlc approach to organizatlons and professlons, Human relations, 22, 1969.

Kerlinger, F.N., The Influence of research on education practlce. TIJdschir ift voor OnderwlJ sresearch, 2, 241-252, 1977.

$\mathrm{Klauw}, \mathrm{C} . \mathrm{F}$. van der, Departmentalization in medical Teaching and Learning. Paper EARDHE Congress, KI agenfurt, 1979.

Klauw, C.F. van der en Lubbers, M., Evalluation of Education: a revlew. Paper EARDHE Congress, KI agenfurt, 1979.

Klerk, L.F.W. de, Intelding in de OnderwiJspsychologie. Van Loghum Sllaterus, Deventer, 1979.

Lelnhardt, G., Madeling and measuring educotional treatment in evaluation. Rev lew of Educ. Res., 50, 3, 393-420, 1980.

Lodewlck, L., Het Llchamelljk Onderzoek: een atlas voor de algemene praktiJk. Bohn, Schel tema \& Holkema, Utrecht, 1978.

Loon, A.J. van, Hoe zlet en patiënt zijn huisarts; psychologlsche goschriften, PG 76-23 Ex. Utrecht, 1976.

Loon, A.J. van \& Schmidt, H.G., Opnleuw de arts-patlëntrelatle. Modisch contact, 32, 1977.

Lugt, P.J.M. van der \& Glsolf, A.C., OnderwiJs in onderzoek; een cursorlsch Junlor co-assistentschap in de neurologle met behulp van audio-visuele medla. Nederlands TIJdschrlft voor Geneeskunde, 116, 696-701, 1972.

Medische Facultelt Maestricht, Raampllan 1974, Medische Facultelt, Maastricht, 1974.

Mertens, F.J.H., De stage als onderwljs 'fencmeen"; een visle vanult de onderwij skunde. Intermedlair 13, $\mathrm{nr} .37, \mathrm{pag} .43-47,1977$.

Mertens, F.J.H., Stages in en beroepsoplelding; het praktljkJ ar in het Hoger Technisch Onderwljs. Olssertatle Universitelt van Amsterdem, 1981.

Mettes, C.T.C.W. en Pllat, A*, Over thet leren oplossen van natuurwertenschappellijke problemen. Dlssertatie T.H. Twente. CoO rapport 42, Enschede, 1980. 
Meuwese, W.A.T., Tlen Jaar onderwlJsresearch aan de THE. In: Inleldingen gehouden op het symposlum 'Onderwilj sresearch', Groep Onderw IJ sresearch THE, rapport no. 19, Elndhoven, 1973.

Mlller, G.E., Teaching and Learning, In: Medlcal School, Harvard, Unlverslty Press, Cambridge Mess. . 1962.

Muggen, 6., Een Instrument voor studletlj metingen. Rapport, Landbouwhogeschool, Wageningen, 1972.

Newble, D.1., The evaluation of cllnical competence. Medical Journal of Australla, 2,180-183, 1976.

Parlett, M. Dearden, G. (ed.), Introduction to lll i um I native EvaluatIon: Studies in Higher Education. SRHE, Gulldford, 1981 (re(ssue).

Planningsgroep PMOH, Praktisch medisch onderwils in de hulsartspraktljk; samenvattend verslag van de stageperlodes sept./nov. 1978, febr./apr. 1979. Intern rapport PMOH-projekt, RIJksunl versitelt Limburg. Maastrlicht, 1979.

Proj ektgroep Summatleve Evaluatle, Ontwikkellingsp I an Sunmatleve Evaluatle. Intern rapport. Rljksunl versiltelt Limburg, Maastricht, 1978.

Reinhardt, A.M. Gray, R.M., A Soclal Psychologlcal Study of Attitude Change In Physlclans. Journal of Medical Education, 47, 112117,1972 .

Rezler, A.C., Attltude Changes in Madical Students during Medicall School: - Revllew of the LIterature. Journal of Medical Education, 49, 1023-1030, 1974."

Rlchards, R.W. et al., The Upper Peninsula Medlcel Education Programme. In Katz, F.M. \& T. Fülop (ed.). Personnel of Health Care. Publlc Health Papers no. 70. WHO, Genève, 1978.

Rlchardson. I.M., A short course on training for practitloner trainars. Health Bulletlin, pag. 344-346, 1976.

Rogers, C.R., Freadom to learn. Merrll1, Ohlo, 1969.

RIJntJes, A.G., BouhulJs, P.A.J., Brouwer, W. \& Mol, A.H., PMOH; evaluatle 1979-1981. Rapport RiJksunlversitelt Limburg, Maastr licht, 1982 .

RIJintJes, A.G., Bounuljs, P.A.J., Brouwer, W. M Mol, A.H., Praktlsch modisch onderwils in de hulsartspraktijk. Medlsch Contact 38, $365-368,1983$.

Schmldt, H.G. \& van Loon, A.J., Attltude-ontwlkkel ling an de Madische Facultelt Masitrlcht. Nota RIJksuniversltelt Llimburg. Maastrlcht, 1976. 
Schnlldt, H.G., Probleem-georlënteerd onderwljs: leren aan de hand van problemen. Metamed lca, 57, 4-16, 1978.

Schmldt, H.G., Activatie van voorkennls, Intrinsleke motivatle an de verwerking van tekst; Studles in probleemgestuurd onderwijs. Dissertatie RIJksuniversltelt Limburg. Van Walraven, Apeldoorn, 1982 .

Schmldt, H.G. \& Bounuljs, P.A.J*, Onderwlls in takgerlchte groepen. Aul a 803, Spectrum, Utrecht, 1980.

Schwarz, M*R. \& Flahault, D., The WAMl-programme, University of Mashington, School of Medicline, Seattle, USA: Decentralizing Medical Education. In: Katz, F.M. \& T. Fülop (od.), Personnel for Health Care. Publlc Health Papers no* 70. WHO, Geneve, 1978.

Scriven, M., The Methodology of evaluatlon. In: Stake, R. (ed.), Perspectives of Curriculum Evaluation. Onlcago: Rand MeNally \& Co., 1967.

Snellen-Balendong, H.A.M., Curr lcullumoverzlcht. Facultelt der ceneeskunde. Jaar I t/m IW - 1981/1982. Rapport Onderzoek van Onderwljs 19A. Rijksunlversl telt Llmburg, Maastrlicht, 1983.

Snow, R.E., Representative and Quasi-representatlve deslgns for Research and Teaching. Revlew of Educatlonal Research, 44, 3 , 265-291, 1974 .

Stenhouse, L., An Introduction to Currlculum research and Development. Helnemann, London, 1975.

Stufflebeam, D., et al., Educational Evaluation and Decision making. Peacock, Itasca 111., 1972.

Swo, Evaluatle-onderzoek. Stlchting voor Onderzoek van het Onderwijs, Den Haag, 1980.

Tlddens, H., Praktlische prlorltelten. Rede ter gelegenheld van de eerste Dlēs Natelis. RlJksuniwersltelt Llimburg, 1977.

Tober, H.J., van der KIauw, C.F. \& Groeneveld, F.P.M.J., Evaluatle van beroepsoplelding tot hulsarts in Rotterdam. Rapport Erasmus Universitelt, Rotterdam, 1977.

Vaags, D.W., Over het oplossen van technische problemen. Dissertatlo TH Eindhoven, 1975.

Verhoef, E., Gebrulk van gezondheldszorgvoorzlenlngen. Dllssertatle K.U. NIJjmegen, 1979 .

Vrles, H. de, De Madische studle gezlen wanuit de student: emotionele aspekten. Medisch Contact, 1979, 34, 397-402.

Wardenaar, E., Scrlptleproblematlek: en denkkader. Fakultelt der Soclale wetenschappen, Kathol leke UnIversitelt Nijmegen, 1980. 
Winer, B.d., Statistical Principles in Experimental Design. McGrawHIII, Now York, 1971.

Wijnen, W.H.F.W., Eval uatio van studieresultaten. Intern rapport IN/BOO 007.76. Rljksuniversittit Limburg, Masistricht, 1976.

wiljen, W.H.F.W., Elnddoel toetsen: warom en hoe? Onder zoek van Onderwils , 6, 3, 16-19, 1977 .

Willght, H.J. \& Knox, J.D.E." Teaching Teachers in General Practice. Medical Education, 11, 48-52, 1977.

Academisering Eerste LIJn. Intern rapport, RiJksuniverstelt Limburg, Maastrlcht, 1981.

Tweede rapport van de afflll latle-advies-commlssle inzake de affll latie van uniwersitelten (facultelten der geneeskunde) met nletacademische zlekenhulzen. Den Haag, 1974. 


\section{Curriculum Vitae}

De auteur van dit proefschrlft werd op 31 december 1947 in Teteringen $(\mathrm{N} . \mathrm{Br}$.$) geboren.$

Na zlJn lagere schooltljd (Sas van Gent en Weesp) vollgide hlJ de gymnaslum-betta-oplelding an het St. Vituscollege in Bussum, dle in 1966 afgesloten werd met het behalen van het elinddiploma. Van 1966-1972 studeerde de auteur psychologle aan de Vrlle Unlversitelt In Ansterdam. Deze studle werd voltoold met het doctoraal-diploma met als speclalisatle psychologische functleleer. Gedurende een Jaer was hilJ vervolgens als stafdocent werkzaam op een Soclale Academle. Van 1973 tot 1975 was hlJ als wetenschappelljk medewerker workzaam blj de groep Onderwljsresearch van de Technische Hogeschool in Elndhoven.

Slnds november 1975 is de auteur werkzaan blJ de Capaciteltsgroep OnderwlJsontwlkkelling en Onderwijsresearch van de R.Jjksunlversitelt LImburg. In verschillende functies was en is hlj betrokken blJ de ontwlkkeling van het curricullum van de facultelt der geneeskunde. Dit proefschrlft vormt de neerslag van een deel van deze activitelten. sinds oktober 1981 makt de auteur deel ult van het bestuur van de facultelt der geneeskunde als portefeullllehouder onderwljs. 